Dissertação de Mestrado entregue à Escola de Engenharia de São Carlos da Universidade de São Paulo, como parte dos requisitos para obtenção do título de Mestre em Arquitetura e Urbanismo.

Área de concentração: Teoria e História da Arquitetura e Urbanismo

\title{
Design para experiência: processos e sistemas digitais
}

\author{
Cynthia Nojimoto
}

Orientador: Prof. Assoc. Dr. Marcelo Tramontano 
AUTORIZO A REPRODUÇÃO E DIVULGAÇÃO TOTAL OU PARCIAL DESTE TRABALHO, POR QUALQUER MEIO CONVENCIONAL OU ELETRÔNICO, PARA FINS DE ESTUDO E PESQUISA, DESDE QUE CITADA A FONTE.

Ficha catalográfica preparada pela Seção de Tratamento da Informação do Serviço de Biblioteca - EESC/USP

Nojimoto, Cynthia
N784d Design para experiência : processos e sistemas
digitais / Cynthia Nojimoto; orientador Marcelo Tramontano. -- São Carlos, 2009.

Dissertação (Mestrado-Programa de Pós-Graduação em Arquitetura e Urbanismo e Área de Concentração em Teoria e História da Arquitetura e Urbanismo) -- Escola de Engenharia de São Carlos da Universidade de São Paulo, 2009 .

1. Design - processos. 2. Design para experiência.

3. Tecnologias de informação e comunicação.

4. Experiência. 5. Sistemas. I. Título. 
Candidata: Arquiteta e Urbanista CYNTHIA NOJIMOTO

Dissertação defendida e julgada em 24/04/2009 perante a Comissão Julgadora:

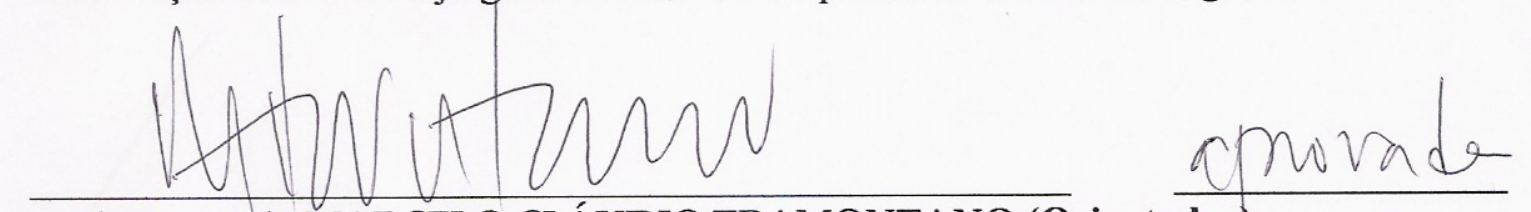

Prof. Associado MARCELO CLÁUDIO TRAMONTANO (Orientador)

(Escola de Engenharia de São Carlos/USP)

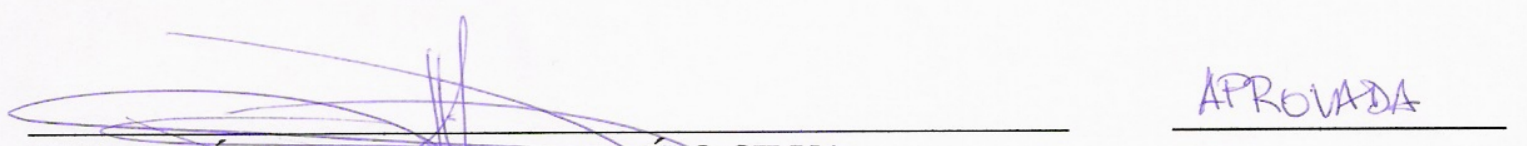

Prof. Dr. FÁBIO DUARTE DE ARAÛJO SHLVA

(Pontifica Universidade Católica/PUC/Campus do Paraná)

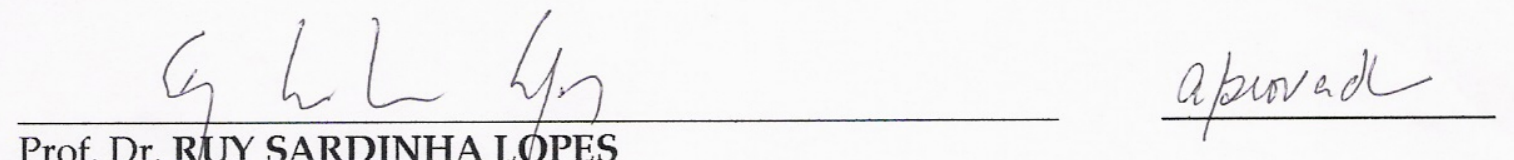

Prof. Dr. RUY SARDINHA LOPES

(Escola de Engenharia de São Carlos/USP)

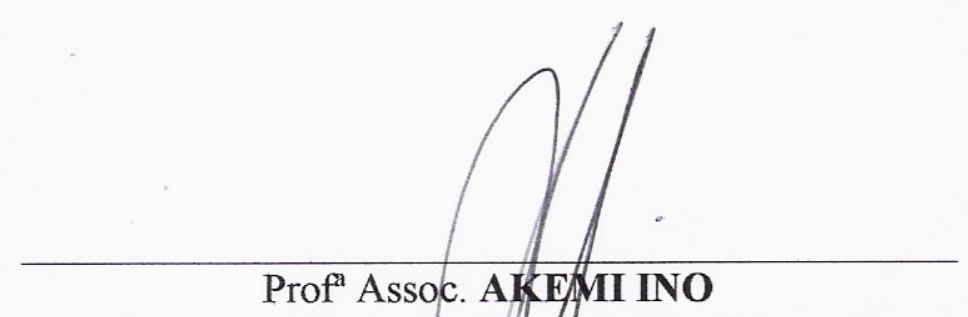

Vice-Coordenadora do Programa de Pós-Graduação em

Arquitetura e Urbanismo

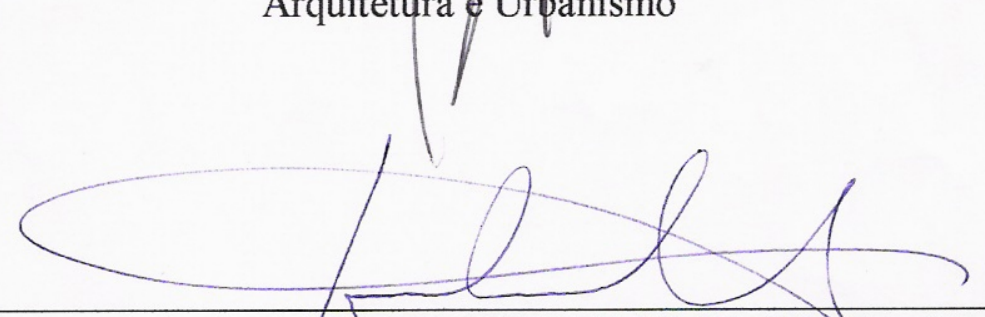

Prof. Associado GERALDO ROBERTO MARTINSDA COSTA

Presidente da Comissão da Pós-Graduação da EESC 

Aos meus pais

Pelo apoio e incentivo dado em todas as escolhas feitas por mim ao longo de minha vida. 



\section{AGRADECIMENTOS}

Ao Prof. Dr. Marcelo Tramontano, por suscitar em mim a paixão pela pesquisa acadêmica;

ao Prof. Dr. Fábio Duarte e ao Prof. Dr. Ruy Sardinha pelas sugestões e considerações no Exame de Qualificação, imprescindíveis para a conclusão desta pesquisa de Mestrado;

aos pesquisadores que encontrei no Nomads.usp que muito contribuíram para o desenvolvimento desta pesquisa: Profa. Dra. Anja Pratschke, a Profa. Dra. Varlete Benevente, Dra. Denise Mônaco dos Santos, Ana Paula Carvalho, João Paulo Marquesini, Rodrigo Seminari, Raquel Arata, Vitor Sanches, Andrei Silva, Edmundo Macha, Lucas Zambianchi, Bruna Biagioni, Armando Biagioni, Karen Piccoli, Matheus de Oliveira, Murilo Girio, Gabriel Prata, Marlon Longo e Márcio Diniz;

aos meus amigos Gabriela Carneiro e Nilton Nardelli pelas discussões nesses anos de pesquisa;

à Elza Miyasaka e à Fábio Queiroz pela grande ajuda nos momentos finais desta pesquisa;

à Mônica Vianna, Nora Cappello e Tatiana Nakanishi, grandes amigas que conheci no Departamento de Arquitetura e Urbanismo, pelas conversas, trocas de idéias e amizade;

aos funcionários do Departamento de Arquitetura, Sérgio, Fátima, João, Alessandro, Lucinda, Marcelinho, Geraldo, Oswaldo, Evandro, Paulo, Zanardi e Dibo, pelos serviços prestados;

aos meus amigos da Jodo Shinshu Shinrankai, Marcel, Hideki e Marco Antônio e aos professores Hideto Myamae e Satoshi Hasegawa pela prontidão e disposição em ajudar a qualquer momento e situação;

ao professor Takamori, por incitar questionamentos sobre a vida;

à FAPESP - Fundação de Amparo à Pesquisa do Estado de São Paulo pela concessão da bolsa de Mestrado e pelo apoio financeiro para o desenvolvimento desta pesquisa;

ao Audrien, pelo companheirismo e confidencialidade. 

Resumo

Esta pesquisa estuda o processo de design envolvido no desenvolvimento de proposições pautadas pelos conceitos do design para experiência. 0 intuito é elaborar abordagens possíveis sobre a relação entre indivíduo e objeto interativo, ou seja, aquele acrescido de instância digital de processamento de dados. Tais abordagens poderão se constituir no processo de design como posturas projetuais para o designer. Desenvolvimentos teóricos e práticos são aliados para se alcançar os fins almejados por essa pesquisa. A investigação teórica, por um lado, contextualiza e fornece conceitos relevantes a serem considerados na relação entre o indivíduo e o objeto interativo. A partir dos conceitos trabalhados, é realizada uma leitura sobre processos de design que exploram essa condição dos objetos. A prática possibilita a aplicação das considerações teóricas levantadas, permitindo o esclarecimento de dúvidas e incertezas sobre o processo. A associação de teoria e prática se constitui como procedimento fundamental para a construção do conhecimento sobre o assunto.

Design para experiência - processo de design - tecnologias de informação e comunicação - experiência - sistemas

\section{Abstract}

This research studies the design process involved in the development of proposals guided by the concepts of design for experience. It aims elaborate possible boardings on the relation between subject and interactive object, that is, that one increased with a digital instance for data processing. Such boardings would be able to consist in the process of design as projective positions to designer. Theoretical and practical developments are allied to reach the aims of this research. The theoretical inquiry, on one hand, contextualizes and supplies relevant concepts to be considered in the relation between the subject and the interactive object. From the worked concepts, a reading is carried through processes of design that explore this condition of objects. The practice makes it possible to apply the raised theoretical considerations, allowing the clarification of doubts and uncertainties on the process. The association of practice theory constitutes a basic procedure for the construction of the knowledge on this subject.

Design for experience - design process - information and communication technologies - experience - systems 



\section{SUMÁRIO}

$\begin{array}{lr}\text { INTRODUÇÃO } & \mathbf{1 3} \\ \text { PERCURSO DA PESQUISADORA } & 15 \\ \text { OBJETIVOS } & 20 \\ \text { ESTRUTURA DA DISSERTAÇÃO__ } & 25\end{array}$

1. DESIGN PARA EXPERIÊNCIA: CONCEITOS 27

1.1 O DESIGN PARA EXPERIÊNCIA __ 29

1.1.1. PROPOSTA E DEFINIÇÕES __ 29

1.1.2. INTERACTION DESIGN E EXPERIENCE DESIGN - APROXIMAÇÕES,

DISTANCIAMENTOS E OS FENÔMENOS DA CONTEMPORANEIDADE. 32

1.2. CONCEITUANDO SISTEMAS E EXPERIÊNCIA _

1.2.1. DO OBJETO AO SISTEMA _ 52

1.1.1. EXPERIÊNCIA: ALGUNS CONCEITOS __ 64

2. PARA A CONSTRUÇÃO DE SISTEMAS PARA EXPERIÊNCIA__ 81

2.1. INTERAÇÕES

2.2. PERCEPÇÃO SENSORIAL__ 90

2.3. CONSTRUÇÃO E RESGATE DE MEMÓRIA: SIGNIFICADOS ASSOCIADOS _ 103

2.3. COMUNICAÇÃO 114

2.4. LEITURA PELOS OBJETOS

2.4.1. PELAS INTERAÇÕES

2.4.2. PELA PERCEPÇÃO SENSORIAL__ 132

2.4.3. PELA CONSTRUÇÃO E RESGATE DAS MEMÓRIAS___ 136

2.4.4. PELA COMUNICAÇÃO _ـ 137

3. CONSTRUINDO SISTEMAS PARA EXPERIÊNCIA: O PROCESSO EM PRÁTICA 143

3.1. ÉOS, Z.IP E PIX 149

3.2. DAS INTERAÇÕES 156

3.3. PELA PERCEPÇÃO SENSORIAL 163

3.4. PELA CONSTRUÇÃO E RESGATE DAS MEMÓRIAS ___ 168

3.5. PELA COMUNICAÇÃO __ 183

CONSIDERAÇÕES FINAIS __ 189

PROCESSO DE DESIGN_ 191

AS TECNOLOGIAS DE INFORMAÇÃO E COMUNICAÇÃO___ 194

DESIGN_LAB: O ESPAÇO DO DESIGNER__ 196

ABRANGÊNCIA DO CONHECIMENTO E EQUIPE MULTIDISCIPLINAR___ 197

PERSPECTIVAS FUTURAS __ 199

REFERÊNCIAS BIBLIOGRÁFICAS __ 201 



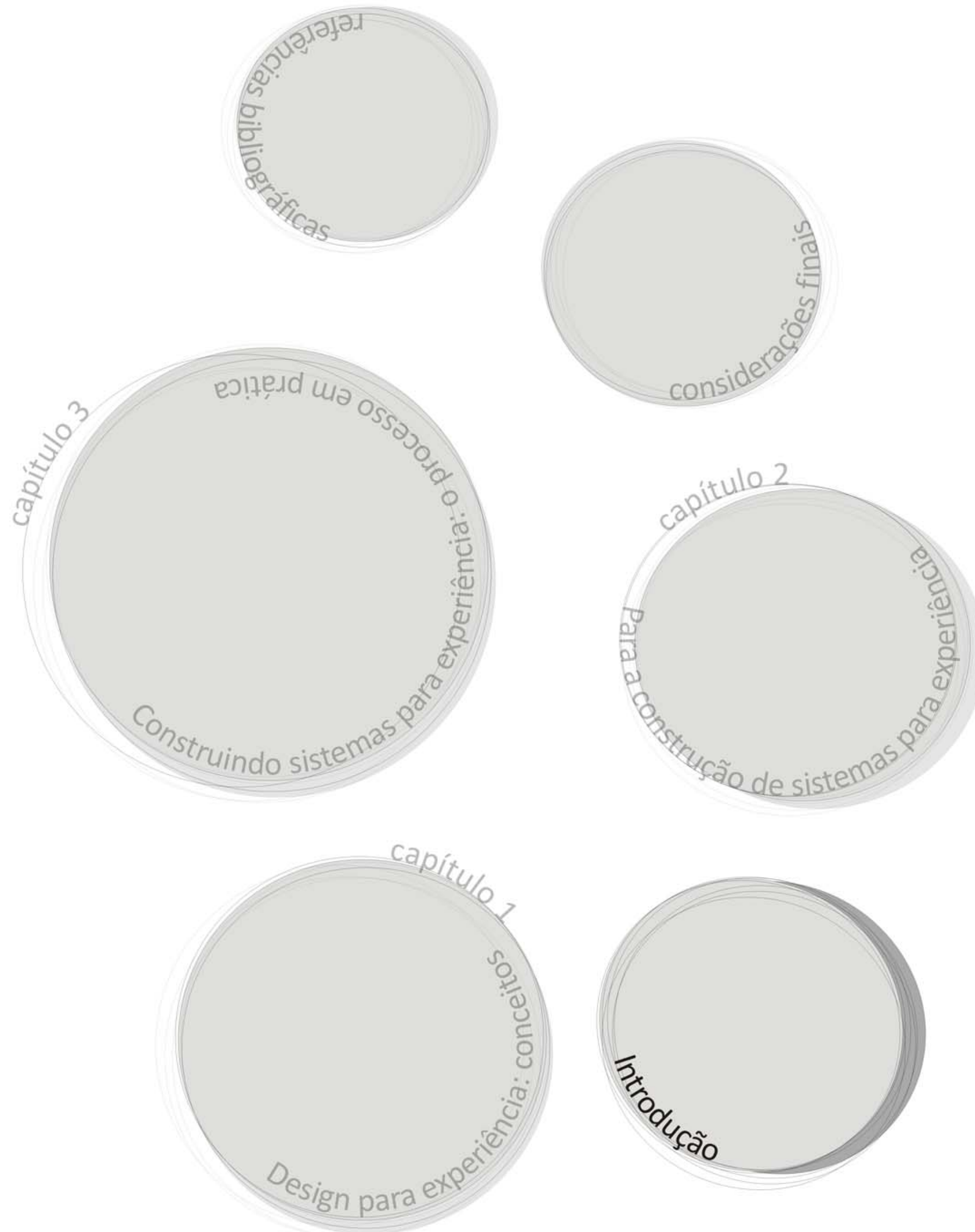





\section{Percurso da pesquisadora}

As origens das indagações e questionamentos abordados nesta Dissertação são anteriores ao Mestrado. O interesse pelo design de mobiliário para habitação foi o ponto de partida para o envolvimento da então aluna de graduação em Arquitetura e Urbanismo da EESC-USP com as atividades de pesquisa acadêmica realizada no Nomads.usp - Núcleo de Estudos de Habitares Interativos.

Tomando como base pesquisas do Nomads.usp que relacionavam modos de vida e comportamento contemporâneos com espaços de morar, partese do pressuposto de que a habitação- brasileira, no geral, e paulistana, especificamente - tal como vinha sendo produzida, espelhava-se num modelo de organização espacial consolidado nos apartamentos construídos para as classes burguesas durante a Belle Époque parisiense, no século XIX (TRAMONTANO, 1998). Verificando inadequações apresentadas por essa matriz espacial frente à diversidade de grupos domésticos e padrões de comportamento e sociabilidade contemporâneos, as pesquisas do Núcleo que se ocupavam de tal temática apontavam a necessidade de um redesenho dos espaços domésticos. Embora o conceito de flexibilidade espacial não representasse uma novidade para a arquitetura, uma das possibilidades aventadas seria dotar os espaços de morar da capacidade de abrigar situações diversas dadas pelas demandas de diferentes formatos familiares, por meio de recursos que permitissem a reconfiguração dos espaços.

Entretanto, ao redesenho da habitação deve também estar associada a revisão do mobiliário constituinte de seus espaços. De fato, percebeu-se que dotar espaços com dispositivos que visem à flexibilidade não garante que sua reconfiguração se dará, de acordo com as necessidades e vontades 
dos moradores. Se o mobiliário utilizado for concebido de forma monofuncional, incapaz de possibilitar tal reconfiguração, os espaços continuarão estanques. Partindo dessa percepção, a pesquisadora procurou entender se o mobiliário proposto por designers brasileiros apresentava sinais de reflexão sobre modos de vida contemporâneo por meio de dispositivos e soluções que contribuíssem para a flexibilização dos espaços.

Além dessa problemática envolvendo projeto e produção de mobiliário, a pesquisa também teve como objetivo compreender como os designers trabalhavam questões relacionadas à sustentabilidade ambiental em suas peças. Procurou-se classificar os objetos segundo diversas categorias de análise considerando o ciclo de vida do produto, ou seja, "o produto desde a extração dos recursos necessários para a produção dos materiais que o compõem ('nascimento') até o 'último tratamento' (morte) desses mesmos materiais após o uso do produto" (MANZINI; VEZZOLI, 2005, p. 91). Assim, pôde-se entender os critérios utilizados pelos designers no desenvolvimento de peças de mobiliário e verificar se de fato contemplavam os conceitos relacionados com a sustentabilidade.

Durante a pesquisa sobre mobiliário, outros trabalhos desenvolvidos no Nomads.usp dedicavam-se a temáticas diversas, porém, também relacionadas com o espaço da habitação. Com a participação da pesquisadora em diversas dessas atividades, novas questões emergiram, suscitando maior aprofundamento dos estudos, num processo contínuo no qual o tema inicial da pesquisa viu-se ampliado e complexizado. Entre esses estudos, estava a investigação sobre os impactos da inserção das tecnologias de informação e comunicação (TIC) no cotidiano das pessoas, determinando novos comportamentos e conformando novas espacialidades. 
Os questionamentos envolvidos na relação entre TIC e habitação chegaram também ao mobiliário, impulsionando pesquisadores a compreender as interlocuções entre essas tecnologias com o design de mobiliário. Assim, juntamente com outros membros do Núcleo, a pesquisadora participou do projeto de pesquisa Kómuniká'tór, financiado pelo CNPq - Conselho Nacional de Desenvolvimento Científico e Tecnológico, que procurou discutir sobre as relações entre as TIC e o design de mobiliário, visando o desenvolvimento de proposições práticas.

No início do projeto, o estudo dessas relações se referenciava às peças de mobiliário com TIC que haviam sido coletadas por outras pesquisas. Em muitos casos representavam apenas a sobreposição de tecnologias existentes a peças de mobiliário funcionalmente convencionais - portanto, apenas acrescentavam uma instância digital de informação e comunicação a uma peça comum. Mas compreendeu-se que o ponto central do incremento tecnológico nas atividades cotidianas das pessoas, nos espaços domésticos e nos produtos não estava na exploração técnica da comunicação ou do processamento digital da informação, mas sim nos processos de comunicação entre as pessoas e as formas de interação com essas tecnologias.

Assim, o termo mobiliário, entendido como objeto para equipar o espaço da habitação para que certas atividades do cotidiano ligadas às necessidades fisiológicas e ergonômicas possam ser realizadas, não parecia mais ser apropriado considerando-se a condição imposta pela instância digital associada a uma entidade física. A questão central passa a ser o entendimento do que as pessoas comunicam e como. Assim, ao invés de mobiliário, adotou-se o termo objeto interativo, sendo que por interativo entende-se a capacidade de processamento digital de dados. Nesse sentido, o objeto interativo não é somente aquele que está na escala do mobiliário. Pode assumir escalas diversas, até mesmo a urbana. 
A complexidade do assunto exigiu uma abordagem multidisciplinar para compreender sobre processos de comunicação entre as pessoas. Buscouse, portanto, contribuições da sociologia, psicologia, filosofia, além das ciências da computação no sentido de possibilitar o desenvolvimento de objetos interativos. Muitos são os autores que procuram formar vínculos entre design e TIC com outros campos do conhecimento. Dourish (2001), por exemplo, aproxima o design de objetos interativos com o pensamento fenomenológico, enquanto McCarthy e Wright (2004) discutem a inserção da tecnologia no cotidiano das pessoas através da corrente filosófica do Pragmatismo, mais especificamente utilizando-se do pensamento de John Dewey.

Assim, as pesquisas realizadas sobre objetos interativos procuraram estabelecer, pela perspectiva do design e da arquitetura, outras formas de abordagem da relação entre indivíduo e objeto, extrapolando as questões técnicas, funcionais e formais. O estudo sobre possibilidades de interação entre pessoas e objetos tornou-se o foco da atenção dos pesquisadores do Núcleo.

Nesse âmbito das discussões sobre design e interação surge o conceito de design para experiência no escopo dos trabalhos desenvolvidos no Nomads.usp. Tal momento instigou novamente a pesquisadora para a investigação e aprofundamento sobre o assunto. O design para experiência é uma abordagem do design que explora a relação dos objetos com as pessoas. No entanto, seu foco está no fomento de experiências através dessa relação das pessoas com os objetos. A pesquisadora abraçou a questão e os resultados diretos de seu envolvimento com o assunto são apresentados nesta Dissertação de Mestrado.

O que torna o design para experiência uma forma peculiar de abordagem das relações entre indivíduo e objetos são os produtos esperados. Eles não 
são constituídos de matéria e sobre eles o designer não possui o controle. Os produtos do design para experiência são as próprias experiências, que ocorrem diferentemente para cada indivíduo. Outro ponto relevante a ser considerado no design para experiência refere-se às tecnologias de informação e comunicação nos objetos, ou seja, aos objetos interativos. 0 design para experiência não pressupõe a exploração de tecnologias digitais e eletrônicas de processamento da informação nos objetos. No entanto, compreende-se que o uso de tais tecnologias pode auxiliar na construção de relações intensas entre o indivíduo e o objeto e, dessa forma, possibilitar a emergência de experiências. Considerações mais aprofundadas sobre o design para experiências são apresentadas no capítulo 1 desta Dissertação.

Entretanto, o foco desta pesquisa não está em dar definições sobre o design para experiência, embora elas tenham sido contempladas. Outras pesquisas no Núcleo se encarregaram de explorar conceitualmente e explicar os princípios norteadores dessa abordagem do design ${ }^{1}$. Este trabalho tem como intuito investigar o processo de design envolvido no design para experiência. Isso porque parte-se do seguinte questionamento: frente aos princípios norteadores do design para experiência, sendo os produtos dessa forma de design não constituídos de materialidade e forma - ou seja, não sendo tangíveis -, que possíveis ações poderiam ser adotadas pelos designers no sentido de conceber objetos capazes de promover o surgimento de experiências em seus usuários?

Embora o termo processo possa assumir várias definições, Berlo (1972) trabalha com a questão do processo voltado para a comunicação humana, entretanto suas considerações são importantes para dar limites ao termo, que pode se tornar tão vago quanto abrangente. Segundo o autor, os processos de comunicação possuem uma dinâmica na qual elementos novos vão surgindo e se relacionado com os demais. Entretanto, quando se

\footnotetext{
${ }^{1}$ Entre elas a desenvolvida por Nardelli (2007) em sua Dissertação de Mestrado intitulada "Design para a experiência e as tecnologias de informação e comunicação".
} 
deseja analisar um processo, essa dinâmica seria congelada. Condição inevitável para estudo do processo. Assim, faz-se importante estar consciente de que no momento da análise, o processo não abarca todos os elementos envolvidos.

Diante dessas considerações, cabe observar o que se entende por processo de design. Nesta Dissertação de Mestrado, é algo que abrange desde o momento das primeiras explorações da relação entre indivíduo e objeto interativo feitas pelos designers até o produto final - no caso, uma experiência. Significa considerar também a consolidação da equipe de designers na qual cada membro contribuiria com seus conhecimentos específicos, a construção do objeto interativo em si, as programações dos circuitos eletrônicos, entre outras atividades. No entanto, a pesquisa visa entender como o designer pode trabalhar as questões referentes às relações entre indivíduos e objetos interativos segundo os conceitos do design para experiência, principalmente como ponto de partida para as ações projetuais. É nesse âmbito do processo de design que esta pesquisa se atém.

\section{Objetivos}

Esta pesquisa de Mestrado tem como objetivo entender o processo de design nas proposições que se pautam nos conceitos que norteiam o design para experiência. Pretende-se explorar as possíveis relações entre individuo e objeto interativo como abordagens a serem consideradas pelo designer ao fazer suas proposições no contexto do design para experiência. Essa abordagem frente ao problema colocado se traduzirá em ações no processo de design. Pretende-se, assim, fornecer insumos para a articulação de idéias e proposições abrangentes em relação aos elementos que possibilitariam a emergência de experiências. 
Vale notar, contudo, que as asserções aqui apresentadas não constituem uma visão estanque, impassível de revisões e futuras compreensões sobre o processo de design. Trata-se de uma possibilidade a ser apresentada para arquitetos e designers que pretendam desenvolver propostas seguindo os conceitos do design para experiência.

Os procedimentos de trabalho adotados para que os objetivos desta pesquisa pudessem ser alcançados envolveram atividades teóricas e práticas numa relação dinâmica de complementação e confrontação dos seus produtos. A pesquisa teórica foi realizada por meio da revisão bibliográfica com a intenção de construir um quadro conceitual acerca dos diversos aspectos envolvidos no processo de design de propostas formuladas segundo o design para experiência. Essa construção conceitual abrange vários campos disciplinares em função do próprio objeto de pesquisa que é formado por uma base ampliada e diversificada de saberes.

A bibliografia utilizada conta com títulos e autores de áreas como filosofia, psicologia, ciência da computação, matemática, linguística, entre outras. No entanto, apesar do design para a experiência permear por várias áreas do conhecimento, parte-se de um olhar da arquitetura e do design, não se pretendendo, portanto, desenvolver uma discussão acerca das peculiaridades de cada assunto abordado em relação às suas respectivas disciplinas, mas sim buscar relações pelas lentes da arquitetura e do design.

Dois procedimentos de trabalho adotados foram fundamentais para o desenvolvimento desta pesquisa: a existência de um banco de dados de objetos com instâncias informatizadas no Nomads.usp ${ }^{2}$ - cuja base foi

2 O Nomads.usp possui um banco de dados de objetos interativos, coletados por pesquisadores de Iniciação Científica e de Mestrado. Os objetos foram coletados predominantemente em páginas da internet de centros de pesquisa, de instituições de ensino, de profissionais de áreas diversas que desenvolvem objetos com instância digital de processamento de dados, apenas para mencionar algumas fontes de pesquisa. $O$ banco contém imagens e descrições sobre os objetos coletados, além de algumas categorias de 
ampliada durante a pesquisa - e a possibilidade de aplicação prática em projetos desenvolvidos pelo Núcleo. O banco de dados forneceu um amplo repertório sobre meios de se explorar as relações entre pessoas e objetos interativos. Através de análises dos objetos nele sistematizados, procurouse compreender de que forma os designers têm trabalhado questões consideradas relevantes para o design para experiência. A aplicação prática de conhecimentos obtidos foi essencial para a compreensão da postura que o designer pode assumir frente às relações entre indivíduos e objetos interativos. A ela segue-se uma análise crítica do próprio processo de design adotado nessas experimentações.

É importante ressaltar o caráter teórico e prático desta pesquisa de Mestrado. Através da teoria construíram-se bases conceituais consistentes enquanto a prática permitiu a verificação e a análise das idéias formuladas, trazendo ainda novas indagações e questionamentos que somente teriam se revelado pela luz da experimentação. Essa forma de se trabalhar o objeto de pesquisa é uma constante dentro do escopo das atividades realizadas no Nomads.usp. As questões levantadas durante o percurso acadêmico desta pesquisadora e que culminaram nesta Dissertação de Mestrado foram construídas pela colaboração entre atividades teóricas e práticas.

O Projeto Conceitual Nomads.Parthenon foi uma das atividades na qual o que estava sendo debatido na teoria pôde ser aplicado em prática. Pelas discussões sobre espacialidades mais flexíveis para possibilitar reconfigurações de acordo com a necessidade ou o desejo do morador, pôde-se, com o projeto, compreender os processos de produção de mobiliário, desde a escolha de materiais menos agressivos ao ambiente, até a execução de peças prototípicas por empresas especializadas no setor moveleiro e sua instalação no espaço da habitação, no caso específico deste 
projeto, uma unidade do tipo flat em um hotel na cidade de São Paulo. O processo de design, na época em que foi realizado, não se constituía de fato como objeto de pesquisa no Núcleo. Mas se uma análise pudesse ser feita nesse momento, as conclusões apontariam para uma postura projetual que não trata apenas os aspectos da boa forma ou do redesenho do mesmo. As peças de mobiliário e dispositivos espaciais foram pensados a partir das atividades que seriam possivelmente realizadas no interior do espaço da habitação, considerando a associação ou a sobreposição de diversas atividades em torno de um objeto ou mobiliário.

Outra atividade prática que apresentou similaridades em termos de processo, embora em contexto diferenciado, foi o projeto e a produção das Isabelitas P.M.G. Trata-se de peças de mobiliário elaboradas para serem elementos de reconfiguração do espaço físico do próprio Nomads.usp, a Unidade Experimental de Habitação 001. A pesquisadora envolveu-se em todo o processo de design, desde as discussões e elaboração do projeto até, posteriormente, na execução das peças prototípicas.

A pesquisadora participou ainda do projeto de reforma do espaço físico do Centro Cultural Arte em Construção do Instituto Pombas Urbanas, como uma das atividades do Nomads.usp no projeto de políticas públicas Comunidades_online: domesticidade e sociabilidade em políticas públicas para inclusão digital, financiada pela FAPESP - Fundação de Amparo à Pesquisa do Estado de São Paulo. Por meio de atividades projetuais, pôdese explorar alguns aspectos relacionados com as proposições do design para experiência, ao se considerar o edifício do Centro Cultural como locus de experiências para aqueles que estão envolvidos nas atividades culturais ali oferecidas pelo Instituto Pombas Urbanas.

A Pacto Digital foi o primeiro projeto no Núcleo nos quais os conceitos do design para experiência puderam ser explorados. Consiste em um projeto 
para o edifício sede de empresa de automação residencial. Foi analisando o processo de design da Pacto Digital que se verificou a necessidade de investigação aprofundada sobre os processos envolvidos no desenvolvimento de propostas segundo o design para experiência.

Entretanto, foi com os objetos desenvolvidos dentro do projeto de pesquisa D.O.S. - Designers On Spot ${ }^{3}$ que pôde se estudar as ações do arquiteto e do designer para o desenvolvimento de proposições segundo o design para experiência. Como procedimento de pesquisa, a aplicação prática do conteúdo teórico forneceu insumos fundamentais para a construção dos entendimentos acerca do processo de design. Os sistemas envolvidos nessa análise são a ÉoS e o z.IP que serão descritos em detalhe no capítulo 3 desta Dissertação.

Outro objeto que permitiu apreender sobre o processo de design foi o PIX. Assim como a ÉOS e o Z.IP, o PIX está no escopo do projeto de pesquisa D.O.S. - Designers On Spot. Refere-se a uma fachada interativa instalada também na Unidade Experimental de Habitação 001. Embora o PIX não tenha surgido dentro do escopo do design para experiência, considerações relevantes podem ser feitas para a contribuição dessa abordagem do design. Do PIX pôde-se ainda analisar a fase de construção do objeto, também entendida como parte do processo de design.

Enfatiza-se a relevância de desenvolver pesquisa em um grupo no qual se incentiva a interlocução com pesquisas envolvendo temáticas diferentes para um objetivo comum. Os projetos temáticos desenvolvidos no Nomads.usp representam esses momentos nos quais as pesquisas convergem para explorar aspectos específicos dentro de um contexto

\footnotetext{
${ }^{3}$ O projeto de pesquisa D.O.S. - Designers On Spot - faz parte do programa TIDIA AE Tecnologia da Informação no Desenvolvimento da Internet Avançada - Aprendizado Eletrônico - financiado pela FAPESP - Fundação de Amparo à Pesquisa do Estado de São Paulo. O objetivo do programa é desenvolver ferramentas de colaboração e comunicação para o ensino à distância, utilizando a internet avançada.
} 
maior. Assim, essa pesquisa, dentro do D.O.S., ocupou-se do entendimento do processo de design dentro da proposta do design para experiência. Outras procuraram explorar aspectos técnicos do desenvolvimento de objetos interativos ${ }^{4}$. Com isso estabelece-se uma relação na qual o grupo provê suporte para o desenvolvimento das pesquisas individuais e permite interlocuções entre as pesquisas, mas também se espera que os pesquisadores contribuam com seus saberes construídos durante os anos de pesquisa, sejam elas de Iniciação Científica, Mestrado, Doutorado ou Pós-Doutorado.

\section{Estrutura da Dissertação}

Teoria e prática foram, portanto, essenciais para o desenvolvimento dessa pesquisa. As investigações, os questionamentos, as proposições, as experimentações e resultados foram organizados nesta Dissertação de Mestrado da seguinte forma:

O capítulo 1, "Design para experiência: conceitos", apresenta as questões conceituais que envolvem o design para a experiência. Contextualiza a abordagem do design para experiência em relação às outras formas de trabalhar o design de objetos aos quais são introduzidos componentes eletrônicos para o processamento digital da informação. Discorre também sobre os conceitos primordiais para o design para experiência: sistemas e experiência.

O capítulo 2, "Para a construção de sistemas para experiência", explora possibilidades para a abordagem da relação entre indivíduo e objeto interativo. Essa abordagem se traduzirá em ações para o designer desenvolver propostas seguindo os conceitos do design para experiência.

${ }^{4}$ Carneiro (2008) desenvolveu pesquisa nessa temática e seus resultados podem ser encontrados na Dissertação de Mestrado intitulada "Objetos interativos: design e tecnologias de informação e comunicação". 
Conta com o aporte teórico desenvolvido no capítulo 1 e do banco de dados de objetos interativos coletado por pesquisas do Nomads.usp, para a análise de objetos que apresentam questões semelhantes. Pela abrangência de objetos disponibilizados pôde-se extrair dados relevantes para a compreensão sobre o processos de design.

O capítulo 3, "Construindo sistemas para experiência: o processo em prática" aborda as experimentações práticas realizadas pelo Nomads.usp. As ações sugeridas e apresentadas no capítulo 2 puderam ser aplicadas no processo de design de proposições do Núcleo. As diversas sessões de projeto realizadas durante o processo permitiram analisar as ações e as abordagens que os designers recorreram no desenvolvimento da ÉOS e do z.IP, principalmente. 

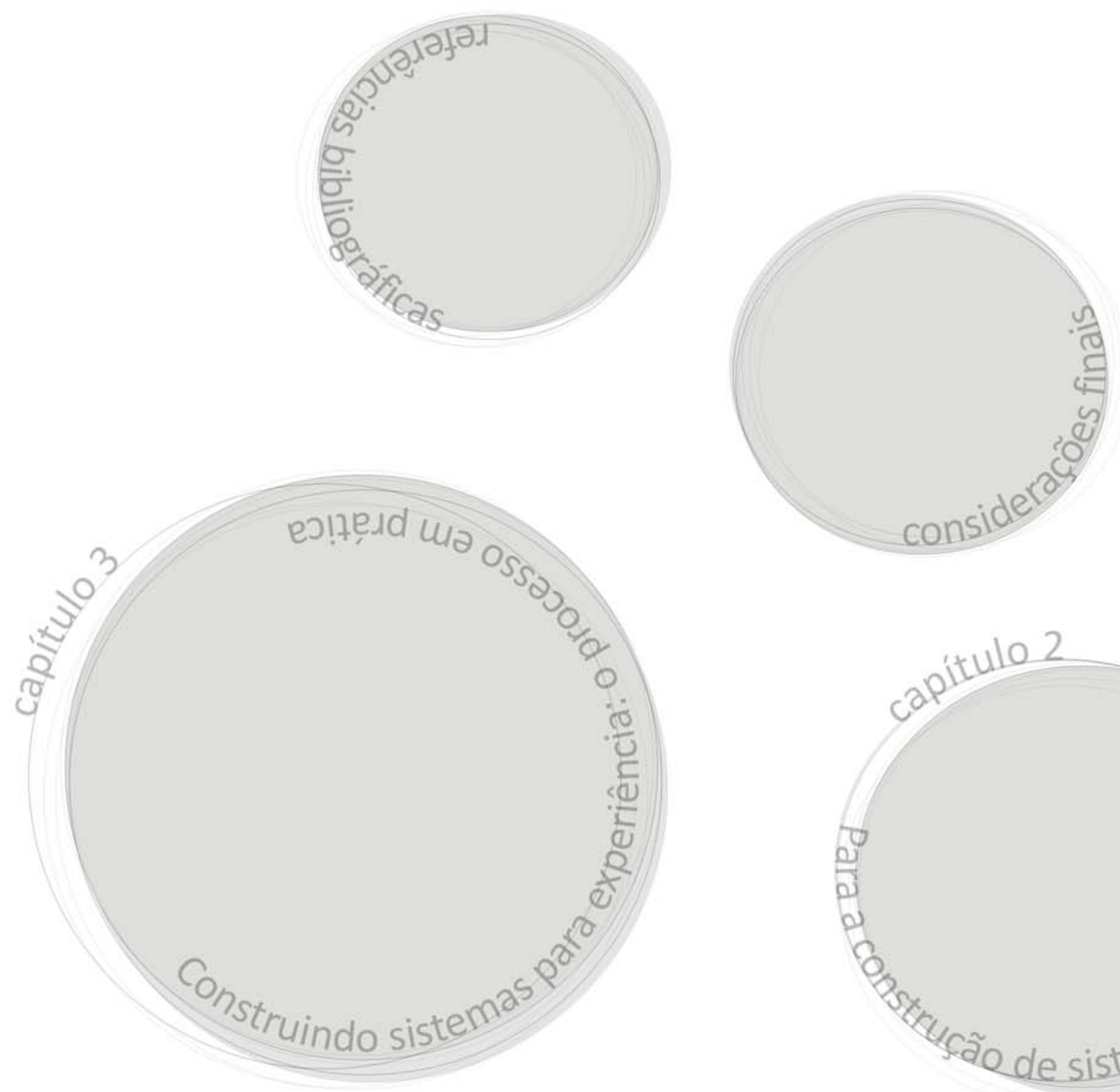

capity/o
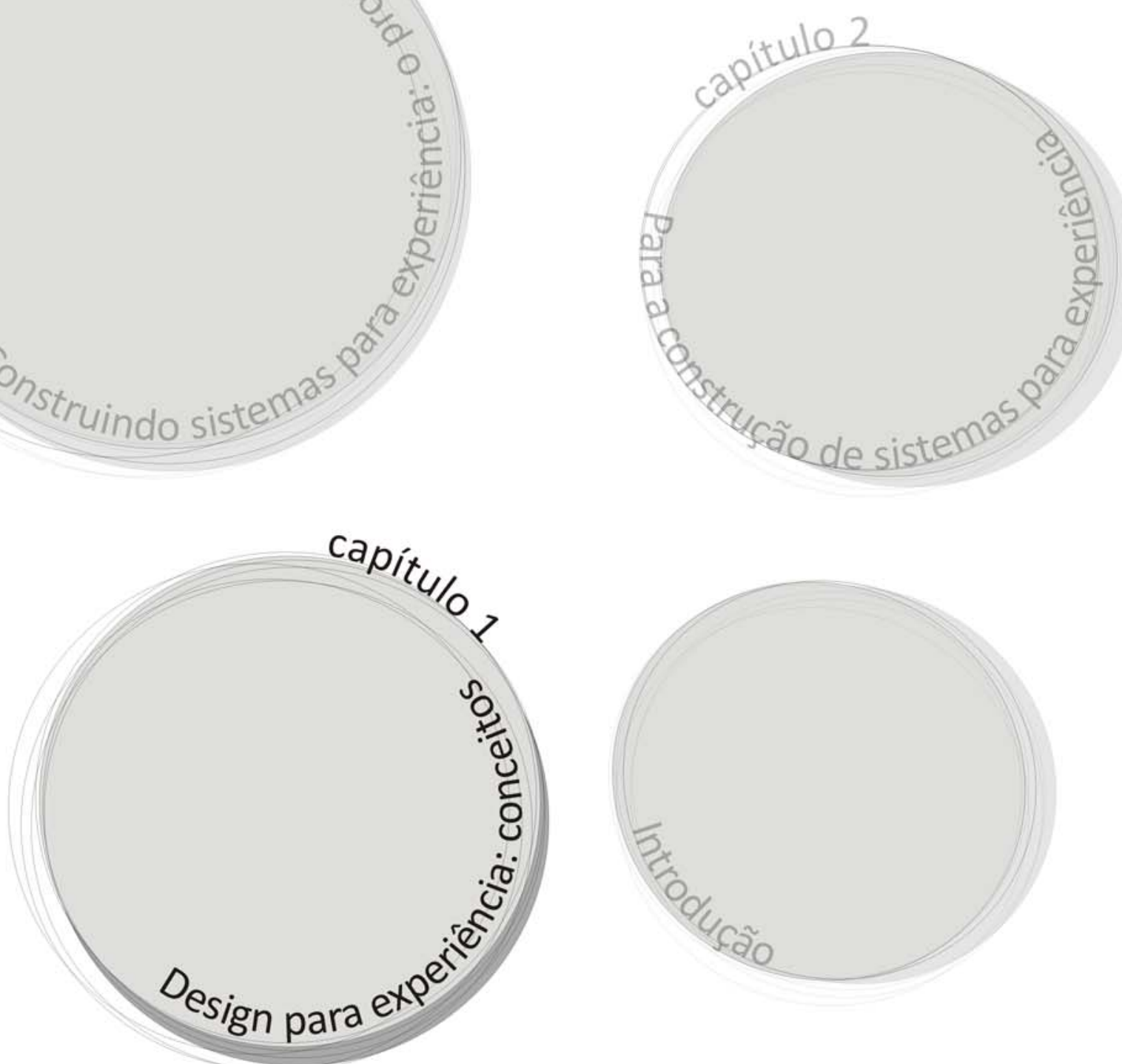

Este capítulo procura dar suporte conceitual e teórico aos aspectos considerados relevantes para o entendimento da construção das relações entre indivíduos e objetos dentro do contexto do design para experiência. A investigação conceitual abrange várias áreas do conhecimento. Assim, dada a diversidade de questões envolvidas neste trabalho, não se espera - e nem é a proposta desta pesquisa - alcançar um nível de profundidade que abarque as peculiaridades sobre cada assunto abordado. Além disso, enfatiza-se que essa investigação é realizada através das lentes das áreas da arquitetura e do design e, portanto, a aproximação sobre cada campo disciplinar é balizado por tal condicionamento. Mas, mesmo considerando a existência de tais lentes, entende-se que há uma abertura no campo de visão que preza pela pluralidade e intercâmbio de conhecimento.

A investigação, neste capítulo, concentra esforços no entendimento de dois conceitos essenciais para o design para experiência: sistemas e experiência. Entretanto, antes da exploração conceitual, faz-se necessário compreender o que está envolvido na proposta do design para experiência, as idéias predominantes e as relações com outras abordagens do design que se aproximam dele sob muitos aspectos, mas que também se apresentam de formas muito distintas.

\subsection{O DESIGN PARA EXPERIÊNCIA}

\subsubsection{Proposta e definições}

Muitas e variadas são as abordagens que podem ser trabalhadas no campo disciplinar do design enquanto atividade vinculada à prática. Não faz parte do escopo desta Dissertação de Mestrado discorrer sobre as origens do termo, dar definições ou limites conceituais sobre o que viria a ser o design, 
ou ainda procurar entender quais são seus produtos e as respectivas naturezas resultantes dessa atividade. Por exemplo, a abordagem do industrial design, ou desenho industrial, chamado também de desenho do produto, difere em relação ao design de interfaces gráficas no que se refere aos produtos obtidos e nos meios de produção.

Assim como acontece com as várias apropriações dadas ao termo design, o design para experiência o aborda sob uma perspectiva própria. Mas para que seus princípios, conceitos e objetivos norteadores possam ser compreendidos em suas peculiaridades, coloca-se como parâmetro a atividade de design adotada pelo desenho industrial - mesmo que essa abordagem também seja compreendida por teóricos e críticos de design sob pontos de vista relativamente divergentes. Heskett (1997), por exemplo, considera o desenho industrial como "um processo de criação, invenção e definição separado dos meios de produção" (HESKETT, 1997, p.10), sendo que a natureza desse processo pode ser o mais variado possível, seja de "um surto de intuição criativa ou de um juízo calculado baseado em dados técnicos e pesquisa de mercado". Sustentando uma visão do desenho industrial como um fenômeno social, Maldonado (1991) entende desenho industrial como uma atividade projetiva dos aspectos formais do objeto, mas admitindo que tal atividade está "fortemente condicionada pelo modo como a produção e o consumo de bens se manifestam em uma determinada sociedade" (MALDONADO, 1991, p.14).

No entanto, sejam quais forem as divergências entre um visão ou outra, ambas concordam em tratar a atividade do designer como um processo no qual são trabalhados os aspectos formais, técnicos e materiais dos objetos. Mesmo que a atuação do profissional contemple os aspectos simbólicos, psicológicos, ou cognitivos, eles estão vinculados à apresentação formal e material dos objetos. Assim, o produto do desenho industrial é tangível e compreendido como mercadoria ao qual é atribuído um valor de troca. 
No design para a experiência, os produtos, entendidos como a consolidação dos objetivos da proposta, não são dotados de materialidade, nem de uma forma específica. Os produtos do design para experiência não são tangíveis como no desenho industrial. Sua existência é real, porém intangível. O produto dessa abordagem do design é a própria experiência.

A intangibilidade dos produtos não é um privilégio desta forma de se fazer design. Se adotarmos como parâmetro o design de interfaces gráficas, seus produtos também são intangíveis embora se pressuponha um meio material que condicione sua existência. É certo também que no design para a experiência existam objetos dotados de materialidade, forma, entre outras propriedades físicas, mas a existência deles não é um fim em si e sim o meio pelo qual experiências podem emergir.

Mas a peculiaridade do design para experiência está no fato de o produto deste design não ser previsível. Além disso, ele pode não se consolidar de fato, ou seja, experiências podem não ocorrer. No entanto, a não previsibilidade do resultado final e a sua não existência é um dado previsto pelo designer. Espera-se que o sistema proposto seja passível de suscitar experiências, mas o designer deve estar ciente de que nem sempre ela emergirá, pois há um grau de incerteza que reside no comportamento de um dos elementos do sistema e sobre o qual o designer não tem e não pode ter o controle total. Este elemento previsto, porém de comportamento não sabido é o próprio homem. Nardelli (2007), ao trabalhar com os conceitos do design para experiência, expressa tal peculiaridade dessa abordagem:

Ainda que o designer não tenha domínio de todas as combinações possíveis que podem levar a experiências diversas, ele é o produtor absoluto dos parâmetros combináveis, o que lhe confere a autonomia do processo de design. Além disso, por envolver aspectos subjetivos que compõem o próprio sujeito que terá a experiência, esse universo nunca poderá ser dominado com precisão (NARDELLI, 2007, p. 107). 
No design para experiência, portanto, não convém falar nos aspectos formais e estéticos como finalidade. Tampouco em funcionalidade ou eficiência. Não se está preocupado em cumprir uma necessidade fisiológica ou ergonômica e nem proporcionar recursos para aumentar ou auxiliar no desempenho de atividades do cotidiano. Existem outras aproximações da atividade prática do design - como as acima apresentadas - que já atuam para suprir a essas demandas. A abordagem do design para experiência se resolve pelas interações entre homem, objetos, ambientes, e outros possíveis elementos do sistema. Sobre a atuação dessa forma de design, Nardelli afirma:

\begin{abstract}
Não se trata de enxergar os objetos como instrumentos facilitadores na execução das tarefas do dia-a-dia, mas pensar as relações entre objetos e indivíduos de maneira mais ampla para além da questão do uso, cuidando de outras instâncias e formas de apropriação possíveis (NARDELLI, 2007, p. 101).
\end{abstract}

Sob o ponto de vista da atividade prática, a apresentação de algumas abordagens da área do design como parâmetro não foi realizada com o intuito de se estabelecer escalas de importância ou relevância dentro dessa área de conhecimento. Trata-se apenas em colocar o design sob outra perspectiva. Assim como as outras abordagens têm seus objetivos, suas propostas e metodologias adequadas para o contexto no qual elas se inserem, o design para experiência também tem caminhado para a construção de processos e entendimentos dentro de seu escopo de atuação.

\title{
1.1.2. Interaction design e experience design - aproximações, distanciamentos e os fenômenos da contemporaneidade.
}

O design para experiência possui vínculos estreitos com outras abordagens do design no que se refere às relações entre indivíduo e objetos interativos. Aponta-se especialmente para duas delas que têm sido objeto de estudo de 
vários pesquisadores e centros de pesquisa e empresas que lidam com o design em âmbitos diversos: o experience design e o interaction design. Elas oferecem uma proposta que não se encerra no objeto em si e buscam no homem a fonte para o desenvolvimento de seus produtos.

A aproximação do design para experiência com essas abordagens não pretende evocar por antecedentes que talvez tenham contribuído para seu surgimento e desenvolvimento, tampouco tenta construir uma visão histórica cronologicamente referenciada em eventos diversos que poderiam ter auxiliado para que o design para experiência se constituísse como tal. Tenta-se estabelecer pontos de convergência e de divergência entre essas diferentes abordagens. Os limites entre elas não são claros, o que permite interlocuções em muito de seus aspectos e faz parecer que se trata de uma única atividade prática do design, revestida de muitos nomes. No entanto, os objetivos norteadores de cada uma são distintos, bem como os procedimentos adotados para se alcançar os fins almejados.

Para falar dessas disciplinas, faz-se necessário contextualizar o momento no qual elas aparecem, ao fim do século XX e início do século XXI. Não se procura colocar os fenômenos da contemporaneidade aqui abordados em uma relação de causa e efeito com as abordagens do design a serem apresentadas. $O$ intuito é mostrar que tais abordagens podem ser melhor compreendidas se for também entendido o contexto no qual elas surgem. Mesmo que brevemente comentados, apresentar alguns fenômenos detectados no mundo contemporâneo pode ajudar a elucidar o panorama com o qual esta pesquisa trabalha.

Assim, dois são os fenômenos a serem brevemente apresentados: as chamadas novas tecnologias de informação e comunicação (TIC), cada vez mais presentes e inseridas no cotidiano das pessoas, e a importância que o homem contemporâneo tem dado em relação a suas experiências. Tanto o 
incremento tecnológico quanto a exaltação das experiências - que quanto mais espetaculares forem, melhor -, estão profundamente interligados.

Rifkin (2000) relaciona os dois fenômenos como parte de um mesmo processo que ele denomina como Era do Acesso. Segundo o autor, as tecnologias de informação e comunicação direcionaram economias e sociedades para uma estrutura em rede (network) na qual "mercados deram lugar às redes, vendedores e compradores foram substituídos por fornecedores e usuários, e praticamente tudo é acessado" ${ }^{5}$ (RIFKIN, 2000, p. 6, tradução nossa).

Essa nova conformação para as relações econômicas e sociais teria contribuído para a formação de indivíduos mais interessados em ter acesso a algo do que preocupados em possuir algo. Nesse sentido, o mundo contemporâneo é mais imaterial ao ser pautado por outros valores que não aqueles diretamente relacionados à posse de bens e mercadorias. Assim, o acúmulo de experiências entra nesse rol de novos valores a serem adquiridos, o que não significa que elas não sejam construídas por um suporte material. E é a indústria da cultura a que mais tem se aproveitado dessa condição para vender as tão desejadas experiências. Rifkin assim comenta:

Os novos homens e mulheres pós-modernos estão constantemente procurando por novas experiências vividas, assim como seus pais e avós burgueses estavam continuamente tentando fazer novas aquisições. As novas indústrias da cultura, uma após a outra, estão criando um número quase infinito de roteiros para proporcionar experiências de vida, assim como as indústrias manufatureiras proveram um vasto número de produtos para serem comprados ${ }^{6}$ (RIFKIN, 2000, p. 211, tradução nossa).

\footnotetext{
${ }^{5}$ No original em inglês: "[...] markets give way to networks, sellers and buyers are replaced by suppliers and users, and virtually everything is accessed" (RIFKIN, 2000, p.6).

${ }^{6}$ No original em inglês: "The new postmodern man and woman is constantly casting about for new lived experiences, just as their bourgeois parents and grandparents were continually in search of making new acquisitions. The new cultural industries, in turn, are creating an
} 
Os economistas Pine e Gilmore (1999) também levantam a questão da experiência como fenômeno contemporâneo e denominam o momento atual como a economia da experiência. As distintas formas que a economia adquiriu durante a histórica são colocadas sucintamente pelos autores da seguinte forma: "enquanto mercadorias são intercambiáveis, bens são tangíveis, serviços intangíveis e experiências memoráveis" 7 (PINE; GILMORE, 1999, p. 12, tradução nossa). Na economia da experiência o que realmente importa é o quão memorável uma experiência pode ser. Os autores não apenas detectam o fenômeno como também desenvolvem metodologias para que empresas se tornem bem sucedidas na nova economia. Um exemplo de empresa bem sucedida (ou pelo menos a mais famosa) na venda de experiências é a The Walt Disney Company. Promovendo experiências através de seus vários parques temáticos, a empresa ainda conseguiu associar serviços e produtos às experiências - de souvenires, vestuário e brinquedos a hotéis, restaurantes e apresentações musicais de teatro.

É possível elencar vários outros exemplos. Desfrutar uma refeição elaborada pelo melhores chefs de cozinha não apenas ao ar livre mas também a muitos metros do solo tendo abaixo dos pés somente a visão de ruas e avenidas da cidade se torna possível dentro do contexto da economia da experiência. Esta é a proposta do Dinner in the Sky, evento promovido por uma empresa que vende como produto uma experiência memorável de alimentação, entre outras experiências aéreas.

É dentro desse contexto contemporâneo apresentado, no qual o incremento das novas tecnologias de informação e comunicação no cotidiano das pessoas e a experiência humana como algo a ser almejado

almost infinite number of scripts for acting out one's life experiences, just as the manufacturing industries provided a vast number of consumer products to buy" (RIFKIN, 2000, p.211).

${ }_{7}$ No original em inglês: "While commodities are fungible, goods tangible, and services intangible, experiences are memorable." (PINE; GILMORE, 1999, p.12). 
pelos indivíduos, colocando-se inclusive acima da aquisição de bens e mercadorias, que surgem as proposições do interaction design e do experience design $^{8}$. Não significa que essas abordagens recorram para as metodologias de Pine e Gilmore (1999) para desenvolver seus produtos. A contextualização auxilia a compreender a mudança de foco do objeto para o usuário na área do design.

O interaction design surge exclusivamente como uma disciplina que trata do desenvolvimento de produtos com TIC. O termo foi cunhado por Bill Moggridge em 1984 juntamente com Bill Verplank ${ }^{9}$. Bill Moggridge, um dos fundadores do $\mathrm{IDEO}^{10}$, é designer com formação pelas práticas e metodologias do desenho industrial. No fim dos anos 70, foi contratado para desenvolver as qualidades físicas e estéticas do primeiro laptop, o GRiD Compass, lançado em 1981. No entanto, com essa experiência, o designer acabou se envolvendo também com o desenvolvimento de software para o laptop. Sobre tal experiência, o designer descreve:

Eu estava surpreso em descobrir que eu me tornei absorvido nas interações com o software quase imediatamente. Eu logo me esqueci das partes físicas do design e me encontrei sugado para o mundo virtual pelo lado da tela. Todo o trabalho que eu havia feito para tornar o objeto elegante para se ver e sentir foi esquecido, e eu me encontrei imerso por horas nas interações que foram ditadas pelo design do software e pelo hardware eletrônico ${ }^{11}$ (MOGGRIDGE, 2007, p. 13, tradução nossa).

\footnotetext{
${ }^{8}$ Embora os termos interaction design e experience design possam ser traduzidos para o português como desenho da interação e desenho da experiência respectivamente, opta-se por utilizar os termos em inglês.

${ }_{9}$ Bill Verplank é engenheiro mecânico e designer de formação, mas intitula-se como interaction designer. Trabalhou com Bill Moggridge no IDEO.

${ }^{10} \mathrm{O}$ IDEO é uma empresa de consultoria em design. Entre os diversos projetos por ela realizados, encontram-se vários trabalhos relacionados com o desenvolvimento de objetos interativos.

${ }^{11}$ No original em inglês: "I was surprised to find that I became absorbed in the interactions with the software almost immediately. I soon forgot all about the physical part of the design and found myself sucked down into the virtual world on the side of the screen. All the work that I had done to make the object elegant to look at and to feel was forgotten, and I found myself immersed for hours at a time in the interactions that were dictated by the design of the software and electronic hardware" (MOGGRIDGE, 2007, p. 13).
} 
Moggridge (2007) percebeu

que profissionais de áreas

diversas estavam trabalhando

no desenvolvimento de

software, micro-controladores,

e computadores. Da tentativa

de aliar a interface gráfica de

software com práticas

provenientes do desenho

industrial, ele cunhou o termo

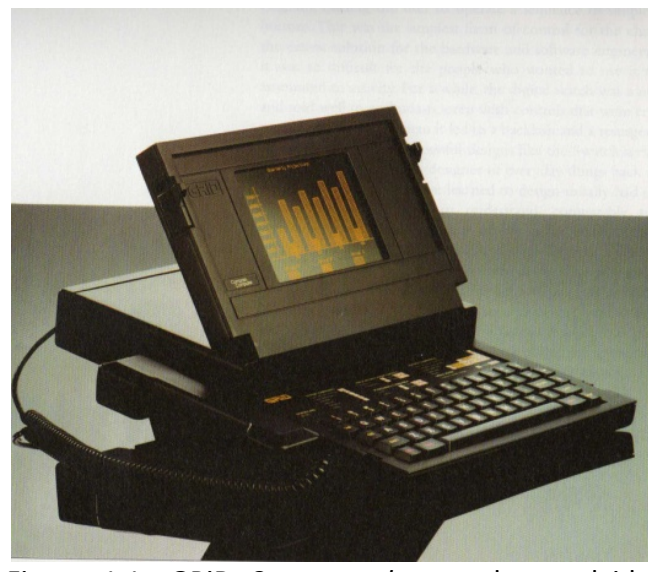

Figura 1.1: GRiD Compass, laptop desenvolvido por Bill Moggridge (MOGGRIDGE, 2007).

"Soft-face", uma junção das palavras software e user-interface design ${ }^{12}$ (design de interface centrada no usuário). Mas para uma disciplina, ainda não era um termo adequado. Assim, o designer passou a denominar como interaction design essa nova disciplina que procura relacionar conhecimento de vários outros campos do conhecimento para o desenvolvimento de produtos como interfaces gráficas, computadores e outros equipamentos eletrônicos.

Eu senti que havia uma oportunidade para criar uma nova disciplina do design dedicada à criação de soluções imaginativas e atraentes no mundo virtual, onde se pudesse projetar comportamentos, animações, e sons bem como formas. Isso seria o equivalente do desenho industrial mas em software em vez de objetos tridimensionais. Como o desenho industrial, a disciplina deveria estar preocupada com os valores subjetivos e qualitativos, deveria partir das necessidades e desejos das pessoas que usam um produto ou serviço, e se esforçar para criar designs que dessem prazer estético assim como satisfação permanente e divertimento ${ }^{13}$ (MOGGRIDGE, 2007, p. 14, tradução nossa).

\footnotetext{
${ }^{12}$ O user-interface design ocupa-se do desenvolvimento de interfaces gráficas e para isso recorre às metodologias do design que focam na experiência dos usuários (user experience).

${ }^{13}$ No original em inglês: "I felt that there was an opportunity to create a new design discipline, dedicated to creating imaginative and attractive solutions in a virtual world, where one could design behaviors, animations, and sounds as well as shapes. This would be the equivalent of industrial design but in software rather than three-dimensional objects. Like industrial design, the discipline would be concerned with subjective and qualitative values, would start from the needs and desires of the people who use a product or service, and strive
} 
O interaction design se consolidou como uma disciplina e argumentos que a definem são apresentadas por vários pesquisadores da área. Sharp, Rogers e Preece (2007) o definem da seguinte forma: "desenhar produtos interativos para suportar os modos como as pessoas se comunicam e interagem em suas vidas cotidianas e laborais" ${ }^{14}$ (SHARP; ROGERS; PREECE, 2007, p.8, tradução nossa). Winograd (1997) ao falar do interaction design, aponta-o como uma forma de se lidar com a tecnologia pela "expansão para aqueles aspectos da computação que são focados sobre as pessoas, mais do que sobre o maquinário"15 (WINOGRAD, 1997, tradução nossa). Em um sentido mais abrangente e que envolve as duas anteriores, Thackara (2001) considera essa prática como uma possibilidade de abordagem das tecnologias digitais na qual é alterado "o foco da inovação da pura tecnologia para o contexto da vida cotidiana" ${ }^{16}$ (THACKARA, 2001, p. 48, tradução nossa). Todas essas definições apresentam em comum 0 direcionamento para uma aproximação dos fenômenos tecnológicos cujo foco não é a tecnologia em si, mas a relação das pessoas com ela.

Como disciplina, possui procedimentos metodológicos próprios para o desenvolvimento de produtos que promovam a interação e a comunicação entre as pessoas. Tais procedimentos são construídos pela contribuição de outras áreas do conhecimento de natureza distintas. Sharp, Roger e Preece (2007) fornecem um panorama das disciplinas que gravitam em torno do interaction design: ciências cognitivas, ergonomia, psicologia, informática, engenharia, ciência da computação, ciências sociais, design gráfico, desenho industrial, entre outras, dependendo dos produtos almejados. Assim, o desenvolvimento dos produtos do interaction design geralmente

to create designs that would give aesthetic pleasure as well as lasting satisfaction and enjoyment" (MOGGRIDGE, 2007, p. 14).

14 No original em inglês: "designing interactive products to support the way people communicate and Interact in their everyday and working lives" (SHARP; ROGERS; PREECE, 2007, p.8)

${ }^{15}$ No original em inglês: "[...] to expansion to those aspects of computing that are focused in people, rather than machinery" (WINOGRAD, 1997).

${ }^{16}$ No original em inglês: "[...] the focus of innovation from pure technology to the contexts of daily life" (THACKARA, 2001, p. 48). 
necessita de uma equipe multidisciplinar nos quais diversos profissionais contribuem conforme seus conhecimentos específicos. Conforme Winograd (1997) afirma:

[...] nós podemos ver o início de uma nova profissão, que pode ser chamada de 'Interaction Design'. Derivando de muitas das antigas disciplinas, ela tem um conjunto distinto de preocupações e métodos. Inspira-se em elementos do design gráfico, design da informação e conceitos da interação homemcomputador como a base para o desenho de interações com (e habitação em) sistemas baseados no computador. Embora computadores estejam no centro do Interaction Design, não se trata de uma sub-área da ciência da computação ${ }^{17}$ (WINOGRAD, 1997, tradução nossa).

E segundo os procedimentos metodológicos, a disciplina mostra a preocupação em desenvolver produtos resultantes do incremento tecnológico dos aparatos eletrônicos e de comunicação utilizando como estratégia o foco nas pessoas ou futuros usuários e não no desenvolvimento da tecnologia por si mesma. Mesmo que o objetivo para a elaboração de determinado produto seja condicionada por uma necessidade de se fazer cumprir tarefas e demandas impostas pelas atividades do cotidiano, a preocupação do designer da interação estará em proporcionar uma relação agradável entre usuário e produto.

Segundo Sharp, Rogers e Preece (2007), os métodos para essa forma de se fazer design são definidos pelas seguintes atividades do processo do interaction design: (1) identificar necessidades e estabelecer condições para que usuários tenham uma experiência satisfatória; (2) desenvolver projetos para cumprir as necessidades apontadas na atividade anterior; (3) construir

\footnotetext{
${ }^{17}$ No original em inglês: "[...] we can see the beginnings of a new profession, which might be called "Interaction Design". While drawing from many of the older disciplines, it has a distinct set of concerns and methods. It draws on elements of graphic design, information design, and concepts of human-computer interaction as a basis of designing interaction with (and habitation within) computer-based systems. Although computers are at the center of Interaction Design, it is not a subfield of computer science" (WINOGRAD, 1997).
} 
versões interativas e (4) avaliar o que está sendo feito durante o processo de design.

Com esses métodos apresentados, torna-se evidente que o ponto central para o interaction design, durante o processo de desenvolvimento de produtos, é o usuário. Nesse processo há duas formas de se abordar a questão da relação entre usuário e objetos interativos: pela consideração das possíveis experiências provenientes da interação, que no interaction design é comumente referenciado pelo termo em inglês user experience design, e pela usabilidade do produto, que é chamada pelos profissionais da área como user-centered design. ${ }^{18}$

Sharp, Rogers e Preece (2007) afirmam que a abordagem dada pelo user experience enquanto método significa trabalhar a maneira "como as pessoas se sentem em relação a um produto e seus prazer e satisfação ao usá-lo, olhá-lo, segurá-lo, abri-lo ou fechá-lo"19 (SHARP; ROGERS; PREECE, 2007 , p. 15 , tradução nossa). Nessa abordagem não se pode projetar uma experiência do usuário, segundo as autoras, mas elas podem ser evocadas por meio de recursos a serem explorados pelos aspectos sensoriais que 0 produto pode provocar no usuário. Aproxima-se do design para experiência quando se reconhece que experiências não podem ser desenhadas, mas o user experience difere no sentido dado à experiência e nos objetivos da proposta. A aproximação da relação entre pessoas e objetos interativos pelo user experience tem como objetivo trabalhar o produto para que ele possa produzir experiências agradáveis e prazerosas para o usuário. No design para experiência, o foco não está em produzir objetos mais agradáveis ao uso. $\mathrm{O}$ foco está nas experiências, mas seu objetivo não é

\footnotetext{
${ }^{18}$ Embora os termos user experience e user-centered possam ser traduzidos por experiência do usuário e centrado no usuário respectivamente, opta-se por utilizar nesta Dissertação de Mestrado os termos em inglês ao serem referenciados no texto.

${ }^{19}$ No original em inglês: "[...] how people feel about a product and their pleasure and satisfaction when using it, looking at it, holding it, and opening or closing it" (SHARP; ROGERS; PREECE, 2007, p. 15).
} 
promover experiências agradáveis ou não. Na verdade, não há como fazer essa distinção entre as experiências, pois para cada indivíduo ela emergirá de forma diferente.

O user-centered design trata das questões referentes à usabilidade do produto. Ao adotar esta abordagem como procedimento de trabalho, designers passam a se preocupar em tornar o produto em desenvolvimento mais fácil de ser usado, manuseado ou manipulado e não apenas com os aspectos relativos aos sistemas informatizados como do produto como um todo, evitando descompassos entre as intenções dos usuários com o que está sendo apresentado a eles. O cientista cognitivo Donald Norman, em seu livro intitulado The design of everyday things ${ }^{20}$, explica o user-centered design a partir de exemplos referenciados em suas próprias vivências em contatos com objetos. Devido às dificuldades por ele encontradas durante a interação com diversos objetos mal desenhados, o autor procura formular bases para se evitar situações de confronto entre usuário e produto do design. Assim, Norman (1988) define essa abordagem do design como "uma filosofia baseada nas necessidades e nos interesses do usuário, com uma ênfase em fazer produtos utilizáveis e compreensíveis." ${ }^{21}$ (NORMAN, 1988, p. 188, tradução nossa). Para a efetivação da boa usabilidade, o autor ainda estabelece algumas diretrizes como tornar as ações do usuário simples de serem executadas, mais visíveis de forma que o usuário não tenha dúvidas em relação ao que deve ser feito, evitar instruções, manuais, ou etiquetas fornecendo informações a respeito de como interagir perante o produto.

\footnotetext{
${ }^{20}$ Neste livro Norman dedica-se exclusivamente às questões da usabilidade. No entanto, alguns anos após o lançamento desse livro, o autor lança Emotional Design: why we love (or hate) everyday things no qual ele passa a discutir acerca dos aspectos estéticos e afetivos envolvidos na interação com os objetos. O modelo proposto por Norman para o desenvolvimento de produtos por diretrizes afetivas também é uma abordagem da esfera de atuação do interaction design. Sharp, Rogers e Preece (2007) apresentam o modelo de Norman no livro Interaction Design: beyond human-computer interaction para explicar as relações afetivas entre o produto e o usuário.

${ }^{21}$ No original em inglês: "[...] a philosophy based on the needs and interests of the user, with an emphasis on making products usable and understandable" (NORMAN, 1988, p. 188).
} 
No entanto, apesar do interaction design procurar por uma ação mais abrangente no que se refere à interação das pessoas com as tecnologias de comunicação e informação através dos produtos, muito do esforço envolvido na atividade da equipe multidisciplinar e no processo de design acaba se voltando apenas para a interação do homem com o computador através de interfaces gráficas, ou então muitas vezes se voltam para a exploração técnica, embora preguem justamente o contrário. McCullough (2005) aponta para tal fenômeno como uma reminiscência de um campo de conhecimento ligado às ciências da computação chamado Interação Homem-Computador ou, em inglês Human-Computer Interaction, cujo acrônimo é $\mathrm{HCl}^{22}$.

O Interaction Design tende a enfatizar interfaces de computador porque estas têm sido a primeira tecnologia genuinamente interativa. $O$ prevalecimento do modelo de interação homem-computador [também conhecido como $\mathrm{HCl}$ - Human-Computer interaction] no design de interface tem sido parcialmente responsável pelo atual estado do computador desktop. $O$ atalho sobre o qual o campo emergiu foi a admissão de princípios psicológicos. A interface gráfica resultante tem sido o foco do campo da interação computadorhomem por aproximadamente 20 anos. Essa interface é um painel de controle virtual cujo design tem permanecido bastante centrado na tecnologia ${ }^{23}$ (McCULLOUGH, 2005, p. 154, tradução nossa).

Segundo Dix et al. (2004), o termo Human-Computer interaction tem se difundido desde o início dos anos 80 . No entanto, o desempenho humano frente aos aparatos tecnológicos tem sido objeto de estudo desde o início século XIX com o trabalho do homem nas fábricas onde eles deveriam

\footnotetext{
${ }^{22}$ Também chamado de Interação Usuário-Computador, em português, ou ainda ComputerHuman Interaction (CHI), em inglês. Nesta Dissertação de Mestrado opta-se por utilizar o acrônimo em inglês, $\mathrm{HCl}$, quando esta disciplina das Ciências da Computação for referenciada.

${ }^{23}$ No original em inglês: "Interaction Design tends to emphasize computer interfaces because those have been the first genuinely interactive technology. The prevailing computer-human interaction (CHI) model of interface design has been partly responsible for the current state of the desktop computer. The breakthrough on which the field emerged was the admission of psychological principles. The resulting graphical user interface has been the focus of the field of computer-human interaction for nearly 20 years. This interface is a virtual control panel whose design has remained quite technology-centered" (McCULLOUGH, 2005, p. 154).
} 
interagir com máquinas. Estudos sobre ergonomia e fatores humanos também fazem parte das origens históricas do $\mathrm{HCl}$ que, antes do advento dos computadores pessoais e das tecnologias de informação e comunicação, chamava-se interação homem-máquina ou em inglês manmachine interaction (DIX et al., 2004).

O $\mathrm{HCl}$ também é formado pela contribuição de distintos campos disciplinares, assim como ocorre no interaction design. As definições sobre ambas as disciplinas também se assemelham não sendo possível estabelecer de fato os limites entre elas. Dix et al. (2004), define $\mathrm{HCl}$ como "design, implementação e avaliação de sistemas interativos no contexto das tarefas e trabalhos do usuário" ${ }^{24}$ (DIX et al., 2004, p. 4, tradução nossa). Sharp, Rogers e Preece (2007), por sua vez, consideram o interaction design como uma disciplina "preocupada com a teoria, pesquisa e prática do desenho das experiências do usuário para todos os tipos de sistemas e produtos" $^{25}$ (SHARP; ROGERS; PREECE, 2007, p. 10, tradução nossa). Assim, apesar do difícil delineamento entre as duas disciplinas, pode-se afirmar que o modelo do $\mathrm{HCl}$ trabalha com tarefas a serem cumpridas, objetivos e procedimentos claros para os usuários dos sistemas interativos (DOURISH, 2004), enquanto o interaction design aponta, ou deveria apontar, para uma abordagem mais ampla das tecnologias e que não se restringe à boa execução de tarefas ou da melhor funcionalidade dos sistemas apenas, embora, conforme McCullough (2005) indica, muitas vezes o próprio interaction design acaba se voltando para uma perspectiva muito centrada na tecnologia e não na interação.

No entanto, é possível reconhecer uma abordagem mais crítica dentro do próprio interaction design. McCullough (2005) aponta que essa "prática da

\footnotetext{
${ }^{24}$ No original em inglês: "[...] design, implementation and evaluation of interactive systems in the context of the user's task and work" (DIX et al., 2004, p. 4).

${ }^{25}$ No original em inglês: "[...] concerned with the theory, research, and practice of designing user experiences for all manner of technologies, systems, and products" (SHARP; ROGERS; PREECE, 2007, p. 10).
} 
crítica em interaction design trabalha com uma história mais aberta e provocativa do que a solução de problemas que a engenharia de equipamentos tem tipicamente feito" ${ }^{26}$ (McCULLOUGH, 2005, p. 165, tradução nossa). Sob essa perspectiva centros de pesquisa e instituições de ensino têm desenvolvido produtos diversos aliando componentes eletrônicos e tecnologias digitais de informação e comunicação ${ }^{27}$. Entre elas, pode-se citar o extinto Interaction Design Institute IVREA, na Itália. O instituto iniciou suas atividades em 2001 e as encerrou em 2005 com a transferência de seus cursos para a Domus Academy. O escopo das atividades do instituto procurava "desenvolver nossa capacidade de inovar produtos e serviços. Estes serviços nos ajudam a interagir um com o outro pelos novos meios de comunicação, pelas tecnologias de rede e de informação" ${ }^{28}$ (IVREA, 2001, tradução nossa).

Muitas dessas práticas têm trazido outras formas de se trabalhar com as tecnologias de informação e comunicação procurando extrapolar a aplicação feita sobre as interfaces gráficas. O Tangible Media Group fundado por Hiroshi Ishii do MIT Media Lab, por exemplo, trabalha nessa esfera de atuação frente às tecnologias digitais de processamento de dados. A equipe de Ishii "procura mudar os 'bits pintados' das interfaces gráficas para 'bits tangíveis' dando forma física para a informação digital"29 (MOGGRIDGE, 2007, p. 523, tradução nossa). Dessa forma, o grupo liderado por Ishii tem como desafio transformar informações em algo passível de ser

\footnotetext{
${ }^{26}$ No original em inglês: "Critical practice in Interaction Design works with a more openended and provocative story than problem solving in device engineering has typically done" (McCULLOUGH, 2005, p. 165).

${ }^{27}$ Exemplos de instituições e centros de pesquisa que podem ser enquadrados sob essa perspectiva do interacion design são vários. Entre eles, o Smart Studio do Interactive Institute na Suécia que atuou entre 1999 e 2005 e posteriormente foi transformado no Art \& Technology Program do Interactive Institute; o curso Designing Interactions do Royal College of Art no Reino Unido; e o Philips Design Center na Holanda, apenas para citar alguns.

${ }^{28}$ No original em inglês: "[...] develops our capacity to innovate new products and services. These services help us interact with each other in new ways-through communications, network and information technology." (IVREA, 2001).

${ }^{29}$ No original em inglês: "[...] seeks to change the 'painted bits' of GUls to 'tangible bits' by giving physical form to digital information." (MOGGRIDGE, 2007, p. 523).
} 
manuseado, em sentido tátil, mas que foge das interfaces gráficas e da manipulação de informação por meio do trio mouse-teclado-tela.

O design para experiência concorda com a construção de uma disciplina formada pela contribuição de distintos campos do conhecimento, tal como preconiza o interaction design. Essa abordagem procura fornecer insumos para o desenvolvimento das relações entre indivíduos e objetos, mas não pressupõe a apropriação das TIC nos objetos. Entretanto, reconhece e assume a potencialidade dada à comunicação humana por meio das novas tecnologias e a ampliação das possibilidades de interação pelos componentes eletrônicos. Prezar pelas relações entre homem e tecnologias digitais torna-se um recurso a ser intensamente explorado para a construção de sistemas dos quais experiências podem emergir nos indivíduos.

Tanto o interaction design quanto o design para experiência colocam, pelo menos enquanto disciplina, o homem como o centro do desenvolvimento de objetos interativos. No entanto, a diferença que se faz notar nas abordagens refere-se ao tratamento dado ao indivíduo. Na abordagem do interaction design o indivíduo é considerado um usuário. Assim seus produtos visam à interação sob a perspectiva do bom uso ou o quão agradável ela será. Seus métodos parecem assim estar em acordo com os objetivos propostos. No design para experiência, o indivíduo não é um usuário. Ele é parte de um sistema, assim como o objeto interativo. É através da relação estabelecida entre indivíduo e objeto que experiências emergirão. Assim, não se trata de falar em usuários e sim em "interatores": um novo termo para o ser que interage com outros elementos do sistema, remetendo à interação e também à palavra ator, que não é compreendido aqui como aquele que representa algo, mas aquele que é o agente da ação. 
Outra abordagem a ser considerada em função dos fenômenos da contemporaneidade é o experience design. Alguns autores o inserem como uma corrente do interaction design (SHARP; ROGERS; PREECE, 2007), ou ainda o qualificam como uma tendência para o desenvolvimento de páginas de internet (McCULLOUGH, 2005). Se essa abordagem está inserida ou não dentro do interaction design, ou se refere aos aspectos da navegação em páginas da internet não é o ponto mais importante. A relevância em abordar o experience design reside na verificação da quantidade crescente de livros e artigos que a têm apresentado como uma disciplina da área do design e como prática cada vez mais recorrente adotada por designers.

$\mathrm{O}$ termo experience design tem sido apresentado de várias formas. Richard Grefé, em artigo publicado pela AIGA ${ }^{30}$ - The Professional Associtation for Design - considera o experience design como "uma disciplina criada pela realidade da comunicação hoje" ${ }^{31}$ (GREFÉ, 2000, p. 1, tradução nossa). Comparando algumas abordagens do design vinculado à comunicação, o autor contextualiza o experience design da seguinte forma:

(...) o design gráfico tratava da forma da comunicação; o design da comunicação tornou-se a disciplina que cobre a forma e o conteúdo. Agora, experience design considera a forma, o conteúdo e o contexto da comunicação ocorrendo ao longo do tempo ${ }^{32}$ (GREFÉ, 2000, p.1, tradução nossa).

Dada a atual realidade dos meios de comunicação que possibilitaram a formação de novas redes econômicas, o significado das coisas enquanto

\footnotetext{
30 AIGA é acrônimo para American Institute of Graphic Arts. Fundada em 1914, suas atividades eram voltadas para a troca de conhecimento em artes gráficas, envolvendo designers, editores, ilustradores, artistas, fotógrafos entre outros profissionais (HELLER; GLUNK, 1989). Atualmente a associação refere-se a si mesma como The Professional Association for Design, por corresponder melhor as suas atividades. No entanto, ainda mantém o acrônimo AIGA como nome.

${ }^{31}$ No original em inglês: "[...] a discipline created by the reality of communication today" (GREFÉ, 2000, p. 1).

32 No original em inglês: "[...] graphic design dealt with the form of communication; communication design became the discipline covering form and content. Now, experience design considers the form, content and context of communication occurring over time" (GREFÉ, 200, p.1).
} 
informação e conhecimento tornou-se valioso enquanto acúmulo de capital. Assim, para o autor, entender o contexto no qual um determinado produto, serviço ou ambiente será inserido torna-se ponto importante para o experience design visto que cada ponto da rede econômica está imerso em significados e valores próprios. A compreensão da AIGA sobre o experience design resulta da verificação da necessidade de uma nova disciplina do design que esteja de acordo com as novas tecnologias de informação e comunicação, mas não enquanto exploração tecnológica e sim como uma forma de se criar valores, não sob os aspectos sociais e sim comerciais.

O Design Council ${ }^{33}$, organização responsável pela promoção do design no Reino Unido, assim como a AIGA, também classifica o experience design como uma disciplina da área do design. Ardill (2007), em artigo para o Design Council, explica o experience design como uma forma de se promover relações positivas entre consumidores e empresas e com isso garantir uma suposta fidelidade entre consumidor e empresa.

O experience design concentra momentos de engajamento entre pessoas e empresas, e as memórias que estes momentos criam. Para consumidores, todos esses momentos de experiência corporativa se combinam para formar a percepção, motivam o comprometimento com as empresas e influenciam a predisposição de novas aquisições no futuro ${ }^{34}$ (ARDILL, 2007, tradução nossa).

As asserções dadas pelas organizações de design sobre o experience design apenas reflete o fenômeno que Rifkin (2000) detecta e que Pine e Gilmore (1999) defendem como o momento econômico atual: a experiência enquanto produto a ser consumido. O Design Council ainda fornece como

\footnotetext{
33 O Design Council foi fundado em 1944 pelo governo do Reino Unido sob o nome de Council of Industrial Design para promover melhorias nos produtos da indústria.

${ }^{34}$ No original em inglês: "Experience design concentrates moments of engagement between people and brand, and the memories these moments create. For costumers, all these moments of corporate experience combine to shape perceptions, motivate their brand commitment and influence the likelihood of repurchase in the future (ARDILL, 2007).
} 
sinônimo de experience design o termo brand experience (ou experiência de marca, ou de empresa, se o termo assim pode ser traduzido) reforçando a relação entre essa abordagem do design como estratégia de venda de produtos proveniente das metodologias adotadas pelo marketing.

Há, no entanto, outras perspectivas que procuram esclarecer o experience design sem colocá-lo nessa lógica mercadológica. De forma mais abrangente, Shedroff (2001) entende a abordagem como uma disciplina recentemente reconhecida como tal e ainda em construção. Em seu livro Experience Design, não procura dar definições nem estabelecer restrições quanto ao campo de atuação para designers. Procura entender as experiências humanas como um dado a ser desenvolvido pelo designer, independente dos recursos a serem utilizados, sejam eles um objeto, uma página na internet, um equipamento eletrônico, um edifício, ou até mesmo um evento. Em relação ao experience design, Shedroff (2001) assim se posiciona:

O Experience Design como disciplina é tão novo que toda sua definição está em fluxo. Muitos o vêem somente como um campo para a mídia digital, enquanto outros o vêem em termos universais que abrangem disciplinas tradicionais, estabelecidas, além de outras tantas como teatro, design gráfico, a narração de histórias, projeto para eventos, projeto de parques temáticos, design de páginas na internet, projeto de jogos, design de interiores, arquitetura, e assim por diante ${ }^{35}$ (SHEDROFF, 2001, p. 2, tradução nossa).

Sobre a arquitetura, o autor comenta uma experiência sua que pode ser entendida como um exemplo do experience design. Shedroff fala de suas impressões ao visitar o Instituto do Mundo Árabe m Paris, projetado pelo arquiteto francês Jean Nouvel. Segundo o autor, ao aproximar-se do

\footnotetext{
${ }^{35}$ No original em inglês: "Experience Design as a discipline is also so new that its very definition is in flux. Many see it only as a field for digital media, while others view it in a broad-brush terms that encompass traditional, established, and, other such diverse disciplines as theater, graphic design, storytelling, exhibit design, theme-park design, online design, game design, interior design, architecture, and so forth" (SHEDROFF, 2001, p. 2).
} 
edifício, a fachada lhe parecia uma grelha que remetia à tradição dos mucharabis árabes. Nada tão surpreendente até então. Ao entrar no edifício, no entanto, surpreendeu-se ao perceber que a grelha, que até então não havia causado nenhuma comoção, transformou-se aos seus olhos em uma sofisticada malha metálica foto-sensível com inúmeras aberturas se auto-regulando de acordo com a intensidade de luz solar. Para o autor, tal experiência foi um momento raro em sua vida. Envolveu não apenas surpresa, mas também uma extrapolação das expectativas.

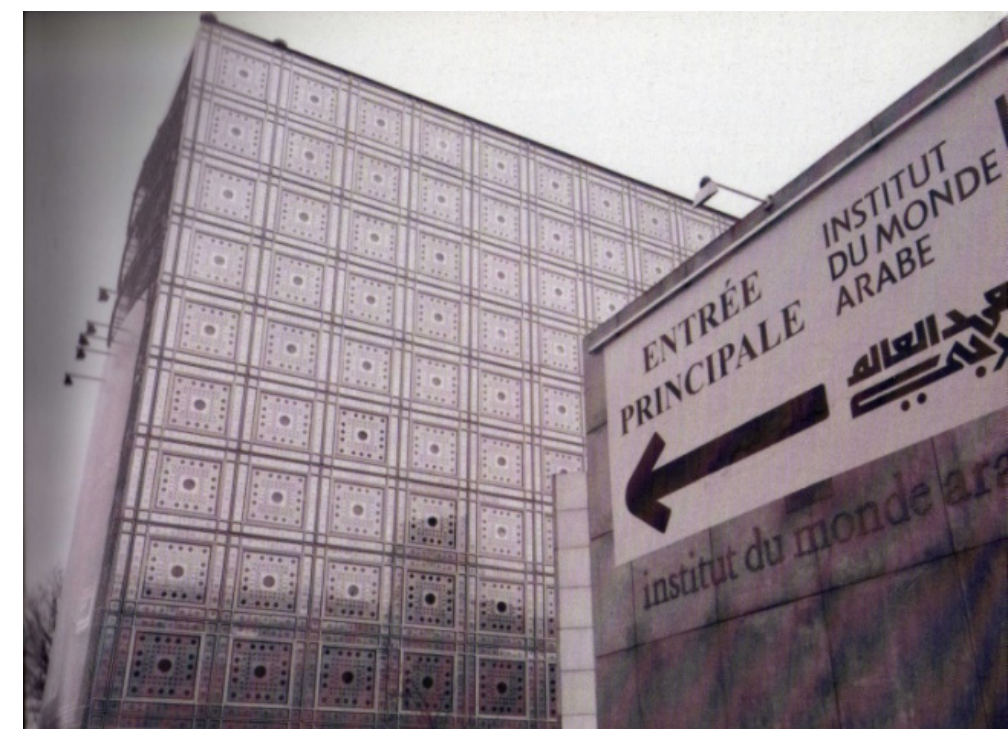

Figura 1.2: Instituto do Mundo Árabe projetado por Jean Nouvel (SHEDROFF, 2001).

Há ainda considerações que restringem o experience design apenas aos grandes eventos, como projeto de exposições, instalação, parques temáticos, ou seja, eventos ou espaços que promovam a experiência. Seriam essas as experiências memoráveis. Para o desenvolvimento da interação dos usuários com objetos, alguns autores assinalam o termo product experience (HEKKERT; SCHIFFERSTEIN, 2008). Essas seriam as experiências do contato cotidiano com objetos. Assim, Hekkert e Schifferstein (2008) afirmam:

Tais experiências [memoráveis e especiais] podem ocasionalmente ser vinculadas a produtos individuais, 
mas aparecem mais no desenho de espaços, instalações, e atrações encontradas em exposições e parques de diversão. O desenho desses tipos de eventos grandiosos e fascinantes é frequentemente denotado como "experience design"36 (HEKKERT; SCHIFFERSTEIN, 2008, p.2, tradução nossa).

Das considerações sobre o experience design acima mencionadas, pode-se entender que ainda se trata de um campo em construção. Faltam métodos e definições precisos, o que não impede que vários designers se autodenominem experience designers e tentem colocá-lo em prática como o próprio Shedroff o faz. No entanto, parece ser um entendimento geral que o experience design é uma disciplina formada por várias outras disciplinas ou campos do conhecimento assim como também ocorre com o interaction design. Há ainda conceitos recorrentes entre aqueles que escrevem e trabalham com o experience design como "engajamento" ou "envolvimento" do usuário e a possibilidade do "desenho" ou "projeto" de experiências estão entre os principais. No brand experience, por exemplo, o valor comercial agregado a um produto está profundamente ligado à habilidade da empresa de envolver o consumidor (ARDILL, 2007). Para Shedroff (2001), entretanto, o envolvimento do indivíduo com o produto, o evento, o ambiente ou serviço é a própria experiência em si e "precisa ser suficientemente diferente do ambiente ao redor da experiência para manter a atenção da experiência" ${ }^{37}$ (SHEDROFF, 2001, p. 4, tradução nossa). A idéia de envolvimento do indivíduo torna-se um requisito e se for seguido conforme o apontado por Pine e Gilmore (1999) é elemento essencial para a constituição de experiências positivas.

\footnotetext{
${ }^{36}$ No original em inglês: "Such experiences can occasionally be bound to individual products, but will more likely arise from designed spaces, installations, and attractions typically encountered in exhibitions and amusement parks. The design of these kinds of overwhelming and compelling events is often denoted as 'experience design'" (HEKKERT; SCHIFFERSTEIN, 2008, p.2).

37 No original em inglês: "[...] needs to be sufficiently different than the surrounding environment of the experience to hold the attention of the experience" (SHEDROFF, 2001, p. 4).
} 
Falar em experiências projetáveis também é recorrente nas palavras dos autores, pesquisadores e profissionais do experience design. O próprio nome dado à disciplina sugere que experiências possam ser projetadas ou estabelecidas. No entanto, conforme Sanders (2002) observa, "há um problema no conceito de experience design. Você não pode desenhar experiências. O experimentar está nas pessoas" ${ }^{38}$ (SANDERS, 2002, tradução nossa). Pode-se dar insumos para que experiências aconteçam, mas não se pode desenhá-las. Conforme a visão de Sanders (2002), "andaimes" devem ser construídos para o experimentar, em uma analogia feita pela autora com a construção de edifícios. Os andaimes são estruturas temporárias e móveis, mas essenciais para se construir algo. Da mesma forma são os objetos, ambientes, serviços ou eventos desenvolvidos para fomentar experiências. Eles são a estrutura, mas não a experiência em si. Seguindo o mesmo raciocínio, Meroni (2005) opta por abordar o experience design não como um design da experiência e sim como um design para experiência.

O design para experiência, tal como é abordado nesta Dissertação de Mestrado, encontra suas origens enquanto termo no experience design. Concorda em muitos aspectos, como por exemplo, no entendimento da necessidade de uma abordagem multidisciplinar. No entanto, em muitos pontos afasta-se das considerações acima mencionadas. Discorda do termo experience design por remeter à idéia de desenho e projeto de experiências. Converge com os questionamentos apontados por Sanders (2002), entendendo o design para experiência como o desenvolvimento de interações que fornecerão as condições adequadas para a emergência de experiências. Adota assim o termo proposto por Meroni (2005), por colocar o termo design para experiência e não design da experiência. Também não restringe nem define a atuação do designer: se serão produzidos interfaces gráficas, objetos, eventos, ambientes, ou outros recursos, apenas durante o

\footnotetext{
${ }^{38}$ No original em inglês: "[...] there is a problem with this concept of experience design. You can't design experience. Experiencing is in people" (SANDERS, 2002).
} 
processo de design, e de acordo com o contexto de cada caso, é que se poderá estabelecer os meios através dos quais se pretende promover experiências. Por fim, não se enquadra como estratégia de marketing, pois não se trata de criar boas impressões e relações entre indivíduos e empresas. Procura, antes, ser reflexivo e estimulador para produção de conhecimento.

Por se tratar de uma disciplina ainda em construção, entende-se esta Dissertação de Mestrado como uma contribuição para o desenvolvimento do design para experiência, permitindo-se investigar e construir bases teóricas próprias. Assim, para esta pesquisa, dois conceitos considerados essenciais são explorados. Por um lado, procura-se entender e estabelecer o conceito de experiência, porém, sem a pretensão de dar definições rigorosas e estanques sobre o assunto e sim recorrendo a uma consideração de experiência para nortear o desenvolvimento da disciplina. Outro ponto central da pesquisa refere-se à compreensão do design para experiência como um sistema. Pensar em como se dão as interações entre elementos de um sistema ao invés de se pensar nos objetos e qual a sua relação com um usuário permite abrir o campo de atuação do designer para posturas mais abrangentes e, portanto, mais coerentes com as propostas do design para experiência.

\subsection{CONCEITUANDO SISTEMAS E EXPERIÊNCIA}

\subsubsection{Do objeto ao sistema}

Diversos são os fatores que devem ser considerados para se alcançar os objetivos do design para experiência. Seja devido ao conhecimento necessário que está envolvido no processo de design, proveniente de campos disciplinares distintos, ou pelos procedimentos adotados para dar as condições necessárias à constituição dos produtos esperados, as 
variáveis a serem trabalhadas pelo designer são muitas e de relações complexas. Entender o design para experiência apenas como o desenho de objetos ou espacialidades significaria colocá-lo sob uma perspectiva reducionista. Existem interações a serem exploradas e interatores a serem considerados bem como suas ações além das ações dos objetos interativos.

Pela complexidade envolvida em todo o processo, o design para experiência deve ser entendido, abordado e trabalhado por uma visão mais abrangente, que permita ao designer articular de forma coerente os fatores a serem explorados para o fomento de experiências. Pelas problemáticas levantadas e trabalhadas por essa abordagem, o direcionamento para um enfoque sistêmico apresenta-se como o caminho a ser adotado tanto para o entendimento do design para experiência enquanto disciplina, como para se trabalhar a relação entre interatores e objetos interativos para a promoção de experiências.

Este trabalho procura dar insumos iniciais para o designer trabalhar na construção das condições para a emergência de experiências de modo que a consideração de um enfoque sistêmico passa a ser a base para o desenvolvimento do design para experiência. É válido notar que o pensamento sistêmico seria válido para o entendimento do processo como um todo, incluindo, por exemplo, a organização da equipe de desenvolvedores e as relações entre seus membros como elementos do sistema - ou quaisquer outros elementos eleitos pelo designer como partes do sistema.

Porém, nessa pesquisa, procura-se compreender as relações estabelecidas entre objeto interativo e interator e estes, pela perspectiva sistêmica, assumem-se como os elementos constituintes do sistema para a experiência. Quanto ao processo de design como um todo, pode-se estendê-lo até o momento da emergência das experiências, que são, afinal, 
o produto esperado do design para experiência. No entanto, esta pesquisa tem como objeto de estudo uma parte anterior desse processo referente às primeiras considerações a serem feitas pelo designer sobre a relação entre indivíduos e objetos, visando à promoção de experiências.

Para trabalhar com o enfoque sistêmico, faz-se necessário investigar o que se entende por sistema enquanto teoria, abordando alguns autores que problematizaram sobre o assunto. A utilização do pensamento sistêmico no design para experiência em relação ao processo de design será discutida no capítulo 2. Por enquanto, pretende-se apenas apresentar um panorama conceitual a respeito das teorias e das discussões que envolvem a idéia de sistemas como uma abordagem para conhecimento do mundo e as repercussões dessa teoria nas artes, na arquitetura e no design.

Não se pretende buscar as origens etimológicas e históricas do termo sistema. Os conceitos aqui abordados datam a partir do início do século XX, momento em que "se tornou visível a necessidade e a exeqüibilidade da abordagem dos sistemas" (BERTALANFFY, 1977, p. 28). Nesse momento, diversos campos do conhecimento, principalmente a biologia e a física, convergiam para uma abordagem sistêmica como uma tentativa de se trabalhar com seus objetos de estudo. Mas para compreender a busca por uma visão sistêmica do conhecimento científico, é necessário contextualizar o período histórico em que tais abordagens tomaram corpo.

No início do século XX as ciências se deparam com uma crise em relação aos seus métodos de investigação científica (BERTALANFFY, 1977; BLAUBERG; SADOVSKY; YUDIN, 1977; MORIN, 2005). A ciência clássica, com sua abordagem mecanicista e reducionista, tratava seu objeto de pesquisa como entidade isolada do seu ambiente e regido por leis universais. Os objetos podem, sob essa metodologia científica, ser mensurados e qualificados segundo propriedades diversas. Pelas palavras de Morin (2005, 
p. 124): o "conhecimento do objeto diz respeito a sua situação no espaço (posição e velocidade), às suas qualidades físicas (massa, energia), às suas propriedades químicas, às leis gerais que agem nele". Reduzir os objetos a sua unidade elementar para estudá-lo é uma postura clássica em diversos campos da investigação científica e que se mostra ainda predominante.

No entanto, no alvorecer do século $X X$, os métodos tradicionais não se mostravam capazes de produzir respostas para uma série de perguntas lançadas por investigações científicas. Para alguns pesquisadores, parecia não haver mais sentido em se estudar os objetos até suas partículas e componentes mais elementares, para se buscar a unidade primeira das coisa, ou seja, não parecia possível explicá-los fechados em si, desconsiderando suas relações com o ambiente no qual os mesmos estavam inseridos. Dentro desse contexto, o conceito de sistema enquanto método de investigação científica ganha força. "Tudo o que era objeto tornou-se sistema. Tudo o que era até mesmo uma unidade elementar, inclusive o átomo, virou sistema" (MORIN, 2005, p.128).

Ludwig von Bertalanffy, biólogo austríaco, reconheceu as limitações dos métodos clássicos de investigação cientifica e detectou a proliferação de abordagens sistêmicas em campos do conhecimento distinto que apesar de trabalharem independentemente uns dos outros apontavam para problemas e resoluções semelhantes em relação ao objetos de pesquisa.

\footnotetext{
A necessidade resultou do fato do esquema mecaniscista das séries causais isoláveis e do tratamento por partes ter se mostrado insuficiente para atender aos problemas teóricos, especialmente nas ciências bio-sociais, e aos problemas práticos propostos pela moderna tecnologia. (BERTALANFFY, 1977, p. 28).
}

O biólogo aponta alguns exemplos na mudança de paradigma dos métodos de pesquisa cientifica. Na física, as pesquisas do mundo sub-atômico que deram origem à mecânica quântica, na química os princípios da 
termodinâmica; na biologia, a visão organísmica dos seres vivos, que se tornou base da biologia moderna; na psicologia, o método da Gestalt que primava pela totalidade psicológica do indivíduo; e nas ciências sociais pela "tendência a considerar a sociedade, a economia e a nação como um todo superodernado às suas partes" (BERTALANFFY, 1977, P. 54).

Pela constatação do enfoque sistêmico em muitas áreas do conhecimento, Bertalanffy compreende que havia a necessidade de transformar essa visão em uma disciplina encarregada de formular os princípios para a idéia de sistemas. A publicação do livro General System Theory pelo biólogo, em 1968, marca o nascimento da Teoria Geral dos Sistemas. No entanto, as considerações do autor sobre o conceito de sistemas são muito anteriores a essa publicação. Nos anos 1920 o biólogo já discutia sobres sistemas, embora ainda restrito a sua área de pesquisa, a biologia.

Bertalanffy (1977, p.84) define sua concepção de sistemas "como um complexo de elementos em interação". Não se pode mais pensar em elementos unos e isolados do ambiente, mas sim em partes que interagem entre si e com o ambiente. Altera-se também a idéia do todo como a soma das partes, pois ele não pode ser explicado pelas características das partes isoladas. Seria através das inter-relações entre as partes que o todo se caracterizaria como tal (BERTALANFFY, 1977).

Por entender sua teoria como um método a ser explorado por vários campos do conhecimento, Bertalanffy (1977) apresenta seus conceitos não apenas dentro da biologia, mas também explora a Teoria Geral dos Sistemas sob diversos aspectos e contextos. Pela matemática vai expor sua teoria por meio de equações. Nas ciências sociais, afirma que elas são as "ciências dos sistemas sociais" (BERTALANFFY, 1977, p. 259) e por tal razão a Teoria Geral dos Sistemas deve ser aplicada em tais disciplinas. $\mathrm{Na}$ psicologia aponta para uma visão do homem como ser "de personalidade ativa” (BERTALANFFY, 1977, p. 256), construtor de seu próprio mundo, 
opondo-se às concepções behavioristas baseadas na idéia de homem como um ser que aprende por condicionamento e responde apenas a estímulos.

O trabalho de Bertalanffy para a elaboração de uma teoria geral para os sistemas foi reconhecido por Edgar Morin, pensador francês, quando este desenvolvia as bases teóricas do pensamento complexo. Porém, este ressalta que o biólogo não trata sua própria teoria com a devida profundidade que o assunto merece, apesar de introduzir o assunto como método científico e influenciar muitas áreas do conhecimento.

Apesar de comportar aspectos inovadores, a teoria geral dos sistemas jamais tentou a teoria geral do sistema; ela se omitiu de aprofundar seu próprio fundamento, de refletir o conceito de sistema. (MORIN, 2005, p. 130).

Assim, Morin (2005) não pensa em sistemas apenas como elementos em interação. Investiga a fundo as proposições sobre sistemas em muitos pensadores de áreas diversas para elaborar uma definição que ao final se constituirá como a base do pensamento complexo. Com isso, associa ao conceito de sistemas os termos inter-relação e organização, sendo que sistema e organização estão ligados pela inter-relação conformando uma relação trinitária entre eles. Assim, "o sistema é o caráter fenomenal e global do qual se revestem as inter-relações cuja disposição constitui a organização do sistema" (MORIN, 2005, p. 134).

Esses três termos, apesar de inseparáveis, são relativamente distinguíveis. A idéia de inter-relação remete aos tipos e formas de ligação entre elementos ou indivíduos, entre esses elementos/indivíduos e o Todo. A idéia de sistema remete à unidade complexa do Todo inter-relacionado, às suas características e propriedades fenomenais. A idéia de organização remete à disposição das partes dentro, em e por um Todo (MORIN, 2005, p. 134).

O conceito de sistemas torna-se muito mais do que partes em interação.

Envolve ainda como as partes ou elementos do sistema se organizam 
dentro e para o Todo. Com isso, chega-se à definição de sistemas como unidade complexa organizada (MORIN, 2005). Cabe ressaltar, no entanto, que o termo unidade referenciando ao sistema não significa algo elementar. Não está se reduzindo o sistema a uma unidade simples e sim o definindo como unidade global, no qual o sistema se transforma em sistema de sistema de sistemas.

De agora em diante, o sistema, ou unidade complexa organizada, surge-nos como um conceito piloto, resultando das interações entre um observador/conceituador e o universo fenomenal; ele permite representar e conceber unidades complexas, constituídas de inter-relações organizacionais entre elementos, ações ou outras unidades complexas; a organização que liga, mantém, forma e transforma o sistema comporta seus princípios, regras, imposições e efeitos próprios; o efeito mais notável é a constituição de uma forma global retroagindo sobre as partes e a produção de qualidades emergentes, tanto em nível global quanto no das partes; a noção de sistema não é nem simples nem absoluta; ela comporta, na sua unidade relatividade, dualidade, multiplicidade, cisão, antagonismo; o problema de sua inteligibilidade abre uma problemática da complexidade (MORIN, 2005, p. 186).

Outro ponto relevante na proposição sobre sistemas desenvolvida por Morin (2005) trata do conceito de emergência. Trata-se do surgimento de qualidades pela organização das partes inter-relacionadas. No entanto, existe um caráter de novidade expressa no conceito de emergência. As qualidades emergentes diferem das qualidades ou propriedades do estado anterior do sistema ou dos componentes do sistema. Assim, a emergência é um produto resultante da organização do sistema (MORIN, 2005).

É considerando o sistema como elementos inter-relacionados e organizados para e em um Todo, que este trabalho explora a relação interatores e objeto interativos dentro do contexto do design para experiência. 0 designer deve entender seu objeto de proposição como um sistema, no qual elementos - sejam eles indivíduos, objetos físicos ou interfaces 
gráficas - estão inter-relacionados. Dessa relação entre as partes surge uma organização intrínseca ao sistema da qual novas propriedades emergirão. As novas qualidades emergentes do sistema no design para experiência são as próprias experiências. Por tal razão, foi adotado desde o início deste trabalho o termo emergência ao referir-se às experiências como os produtos a serem alcançados pela proposta do design para experiência.

Um dos pontos de convergência entre arquitetura, design e artes com as teorias dos sistemas é feito pela Cibernética. A Cibernética ${ }^{39}$ foi formulada por Norbert Wiener e publicada pela primeira vez em 1948. Trata dos mecanismos de controle e regulação dos canais de comunicação para garantir que as mensagens enviadas por emissor cheguem a um receptor com o mínimo de ruído. O momento era propício para as teorias na área da comunicação e no mesmo ano Claude Shannon publica A Mathematical Theory of Commnunication ${ }^{40}$, no The Bell System Technical Journal, traduzindo a questão da transmissão de mensagens de um ponto ao outro em termos matemáticos e estatísticos. Essas teorias extrapolaram suas áreas originais e foram apropriadas por outras como as ciências sociais aplicadas como a arquitetura e o design.

Segundo Bertalanffy (1977), é recorrente a identificação da teoria dos sistemas com a Cibernética. As relações entre as duas são evidentes, ambas surgem no contexto dos avanços tecnológicos em telecomunicação e na

\footnotetext{
${ }^{39} \mathrm{O}$ termo cibernética vem da palavra grega kubernetes que significa a arte de pilotar. Foi utilizado Norbert Wiener para denominar "o estudo das mensagens como meios de dirigir a maquinaria e a sociedade, o desenvolvimento de máquinas computadoras e outros autômatos" (WIENER, 1968, p.15). Tem com intuito "desenvolver uma linguagem e técnicas que nos capacitem, de fato, a haver-nos com o problema do controle e da comunicação em geral" (WIENER, 1968, p.17).

${ }^{40}$ Considerando que um dos problemas fundamentais da comunicação é a reprodução fiel da mensagem de um ponto a outro (SHANNON, 1948), Claude Shannon desenvolve em termos matemáticos uma medida para a informação, garantindo a reprodução mensagem em um canal de comunicação por meio de estruturas estatísticas de seus pontos de origem e de destino. A teoria de Shannon trabalha em nível sintático, ou seja, não se preocupa com a semântica envolvida nas mensagens. Trata dos aspectos físicos envolvidos nos sistemas de comunicação. 0 capítulo 2 abordará a teoria da comunicação de Shannon como base para o designer elaborar esquemas de comunicação.
} 
busca por outros paradigmas de abordagem científica. A Cibernética, pelo menos no momento em que ela havia sido formulada, desenvolve seus princípios sobre uma base sistêmica, no entanto não se pode equalizar as duas ciências. As teorias dos sistemas tratam de seu objeto de pesquisa em um sentido muito mais amplo do que a Cibernética, que trabalha com sistemas de controle auto-reguladores. Assim, Bertalanffy (1977) afirma:

\begin{abstract}
A cibernética enquanto teoria dos mecanismos de controle na tecnologia e na natureza, fundada nos conceitos de informação e retroação, é apenas uma parte da teoria geral dos sistemas. Os sistemas cibernéticos são um caso especial, embora importante, dos sistemas que apresentam auto-regulação (BERTALANFFY, 1977, p. 35).
\end{abstract}

Duas personalidades merecem destaque na aproximação entre cibernética e arquitetura. São eles Cedric Price e Gordon Pask. Price pertence a uma geração de arquitetos ingleses formada nos anos 1950 dentro do contexto da produção arquitetônica entendida como ação social e forma de arte (FRAMPTON, 1997; LANDAU, 1984), prezando por uma arquitetura comprometida com os efeitos que ela pode ter sobre os indivíduos. Landau denomina essa postura como "filosofia de habilitação" (philosophy of enabling) (LANDAU, 1984). Price também era um entusiasta das recentes tecnologias da informação e comunicação e acreditava no potencial tecnológico desempenhando um papel crítico na arquitetura. Com essa postura desenvolve seu projeto mais paradigmático, o Fun Palace, com a contribuição do ciberneticista Gordon Pask.

O projeto do Fun Palace data de 1961, mas não foi construído. Foi encomendado por Joan Littlewood, diretora do Theatre Workshop do Theatre Royal. O objetivo da diretora era promover um "laboratório da diversão" para o desenvolvimento de atividades diversas ligadas às artes, porém rejeitando o conceito de entretenimento passivo, como ocorre com os parques temáticos. A idéia do Fun Palace consistia em dar ao visitante a possibilidade de interação com o edifício através de dispositivos que 
permitiam a flexibilização do espaço. Assim, o espaço poderia ser reconfigurado conforme o desejo de seus usuários.

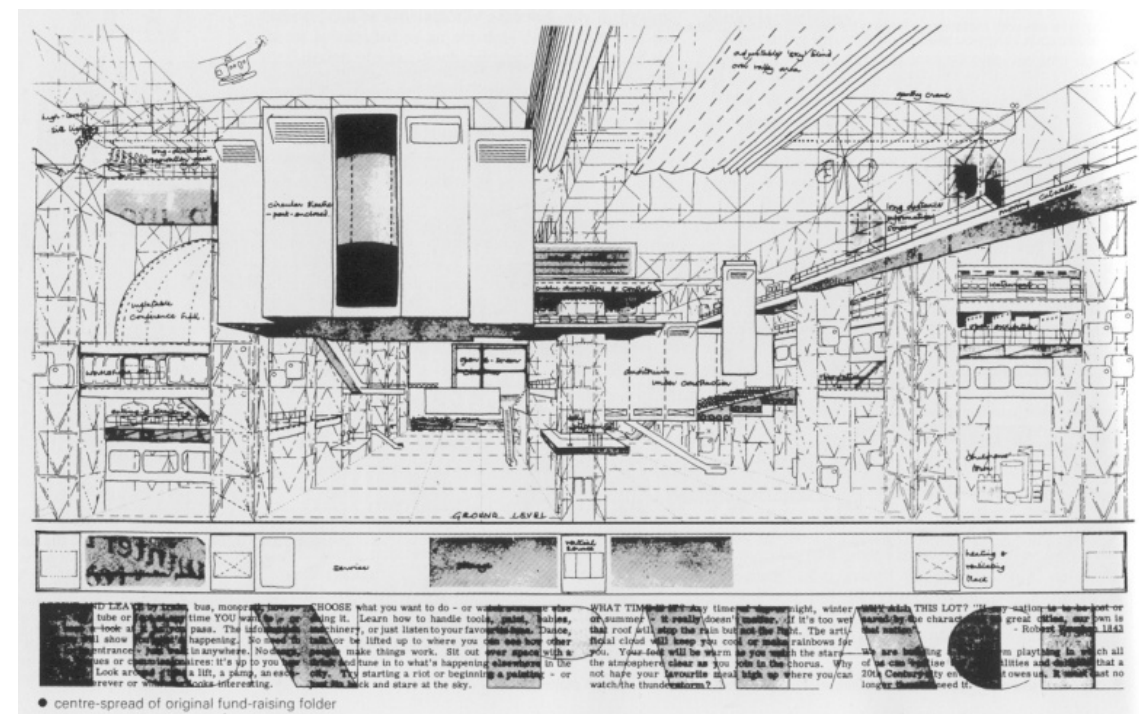

Figura 1.3: Perspectiva do Fun Palace projetado por Cedric Price (PRICE, 1984, p. 58).

A relevância desse projeto encontra-se, entre outros aspectos, na contribuição dada por Gordon Pask. O ciberneticista aproximou arquitetura e cibernética, defendendo uma visão holística do projeto de arquitetura e apontando para o arquiteto como o designer de sistemas (PASK, 1969). O momento era propício e Frazer (2001) assim aborda o contexto histórico e a relação de Pask com a arquitetura:

O pensamento arquitetônico de vanguarda nos anos 1960 estava preocupado com os assuntos sobre flexibilidade, impermanência, pré-fabricação, computadores, robótica e uma abordagem global sobre energia, recursos e cultura. O pensamento sistêmico implícito na arquitetura inevitavelmente veio para adotar a cibernética e a cibernética na arquitetura inevitavelmente veio para aceitar Gordon Pask. Gordon encontrou na AA [Architectural Association] um ambiente complacente, a AA entusiasmou-se com Gordon e o relacionamento fértil estendeu-se por 30 $\operatorname{anos}^{41}$ (FRAZER, 2001, p. 642, tradução nossa).

\footnotetext{
${ }^{41}$ No original em inglês: "Avant-garde architectural thinking in the 1960s was preoccupied with issues of flexibility, impermanence, prefabrication, computers, robotics, and a global approach to energy, resources and culture. The implied systems thinking in architecture
} 
A abordagem cibernética também está presente nas artes. Em 1968, a exposição Cybernetic Serendipity, organizada por Jasia Reichardt, procurava "explorar e demonstrar algumas relações entre tecnologia e criatividade" 42 (REICHARDT, 1969, p.5, tradução nossa). Porém a exposição não contava apenas com artistas. Matemáticos, engenheiros, arquitetos entre outros profissionais apresentaram trabalhos na exposição, inclusive Gordon Pask. Segundo a curadora, a formação não representava um dado relevante, portanto, a menos que o visitante lesse todo o catálogo ou as informações contidas nas obras é que se poderia identificar a formação de cada autor. 0 propósito dessa suposta omissão da área de competência de cada expositor reforçava, na verdade, um caráter inovador da exposição. As novas tecnologias de informação e comunicação estendiam as possibilidades de expressão estética e criativa mesmo para aqueles que não possuíam formação em Artes. "Assim, pessoas que nunca teriam colocado um pincel no papel, ou uma tela, tinham começado a fazer imagens estáticas ou animadas que se aproximavam e ofereciam uma aparência idêntica daquelas chamadas de 'arte' e colocadas em galerias" ${ }^{43}$ (REICHARDT, 1969, p. 5 , tradução nossa).

Não se pretende abordar profundamente a discussão colocada por essa exposição, vale pontuar algumas considerações sobre o evento além da relação entre arte e cibernética. A exposição procurou refletir sobre questões como quem faz arte e quem são os artistas, visto que naquele momento, com novas possibilidades oferecidas pelo incremento do computador na vida cotidiana das pessoas, qualquer um poderia ser um artista em potencial.

\footnotetext{
inevitably came to embrace cybernetics and cybernetics in architecture inevitably came to embrace Gordon Pask. Gordon found the AA to be a sympathetic environment, the AA warmed to Gordon and the fertile relationship extended for the next 30 years" (FRAZER, 2001, p. 642).

${ }^{42}$ No original em inglês: "[...] exploring and demonstrating some of the relationship between technology and creativity." (REICHARDT, 1969, p. 5).

${ }^{43}$ No original em inglês: "Thus people who would never have put pencil to paper, or brush to canvas, have started making images, both still and animated, which approximate and often look identical to what we call 'art' and put in public galleries." (REICHARDT, 1969, p. 5).
} 
No contexto contemporâneo, destaca-se o trabalho do arquiteto Usman Haque que tem se dedicado ao desenvolvimento de objetos e ambientes interativos, recorrendo às tecnologias de informação e comunicação e aplicando-as dentro do contexto arquitetônico. Em alguns de seus projetos, os conceitos cibernéticos de Pask são tomados como princípios norteadores. Entre eles, destaca-se o Evolving Sonic Environment ${ }^{44}$ desenvolvido em parceria com Robert Davis do departamento de Psicologia do Goldsmith College de Londres. Trata-se de um ambiente sônico formado por uma "sociedade" de equipamentos cujo comportamento é alterado em função da presença e a ausência das pessoas que nele estão. O comportamento de cada equipamento é um som emitido numa determinada frequência. Quando uma pessoa entra nesse ambiente, a frequência é alterada e a pessoa passa a ouvir o resultado de sua intervenção no espaço. Portanto, segundo os princípios cibernéticos de segunda ordem, essa pessoa é o observador, que ao observar o sistema também faz parte dele, ou seja, é capaz de alterá-lo.

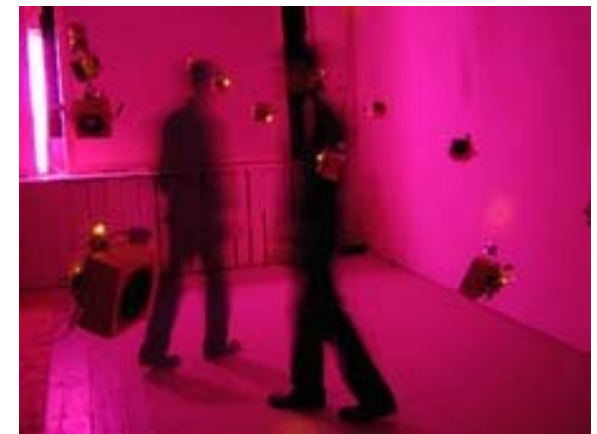

Figura 1.4: Detalhe do equipamento da instalação Evolving Sonic Environment. (HAQUE, 2006b).

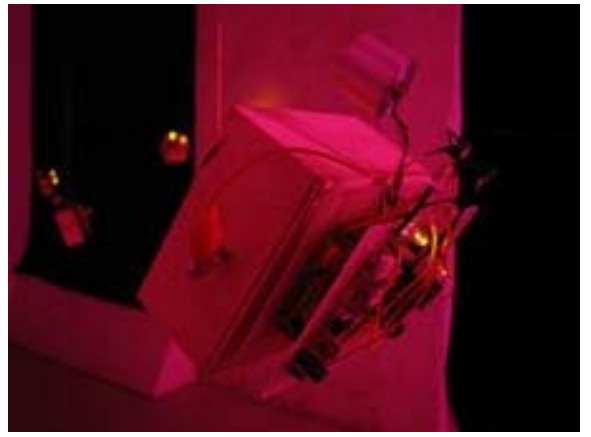

Figura 1.5: Evolving Sonic Environment de Usman Haque e Robert Davis (última versão do projeto em 2006) (HAQUE, 2006b).

As experiências cibernéticas nas artes, na arquitetura e no design, portanto, não se configuram como uma novidade. Reinventando e reintroduzindo os conceitos desenvolvidos por Wiener em 1948, e explorados por outros pesquisadores e pensadores, como Gordon Pask, artistas, arquitetos e

\footnotetext{
${ }^{44}$ No Brasil, o projeto foi exibido em 2006 na exposição Emoção Art.ficial 3.0 - Interfaces Cibernéticas - promovida pelo Itaú Cultural.
} 
designers apontam para a relevância do pensar sistêmico em suas áreas de atuação. Na presente pesquisa, porém, o enfoque não está numa abordagem dos sistemas para experiência sob uma perspectiva cibernética. O intuito é entender o design para experiência através de uma visão mais ampla, fornecida pelas teorias dos sistemas, ou seja, compreendê-lo como um sistema no qual as partes estão em interação em um todo organizado para a emergência de novas qualidades, sendo o designer quem define os limites desses sistemas, não no sentido restritivo que a palavra limite implica, mas como seu campo de observação.

\subsubsection{Experiência: alguns conceitos}

O design para experiência elabora sistemas que têm como objetivo a emergência de novas experiências. Mas o que se entende por experiências? Como podem elas ser consideradas e abordadas no vasto contingente de definições que as rodeiam? Até o presente momento não foram oferecidas explicações mais detalhadas sobre o assunto. Este item se ocupa, portanto, em fazer considerações sobre o conceito de experiência, um dos aspectos fundamentais para o entendimento do design para experiência.

Os entendimentos dados ao termo experiência são bastante diversos. Contudo, faz-se necessário apontar e compreender algumas asserções dadas ao termo, na medida dos interesses da presente pesquisa. No senso comum o termo envolve de habilidades adquiridas por um indivíduo (ser experiente em alguma atividade) a registros de um tempo passado (como as memórias passadas em relação a algo). Entre pensadores de diversas áreas e em períodos distintos, a idéia de experiência também é assunto recorrente, seja como problema epistemológico, procedimento metodológico ou abordagem lógica do pensamento. 
Como método de investigação, este trabalho busca o conceito de experiência em doutrinas filosóficas e em pensadores que apontaram para a questão da experiência sob determinados aspectos, principalmente como um problema relacionado à obtenção do conhecimento. Não se tem a pretensão de entender suas especificidades e suas peculiaridades em relação aos outros questionamentos por eles levantados. Mesmo em relação ao enfoque dado por cada doutrina ou pensador ao termo experiência, não seria possível a exploração em sua totalidade. Sua relação com outras problemáticas de cunho filosófico envolve competências específicas da filosofia, que não poderiam ser tratadas nesta Dissertação.

Também não seria possível tratar de todas as correntes filosóficas que fazem alusão ao conceito de experiência. Assim, o recorte metodológico de investigação deste trabalho delimitou duas correntes específicas: o Empirismo no século XVIII e o Pragmatismo nos séculos XIX e XX. A seleção das abordagens se justifica por sua relevância em relação aos conceitos de experiência, o que não significa que outras doutrinas não sejam importantes em relação ao assunto. Os motivos que os colocam essas doutrinas em foco referem-se ao legado deixado por elas, seja como um problema epistemológico no Empirismo ou como uma questão lógica no Pragmatismo.

O cartesianismo dominou o pensamento filosófico durante todo o século XVII. Introduziu um novo método de pensar e de se construir o conhecimento. No entanto, já ao final desse mesmo século, o sistema cartesiano e as concepções mecanicistas do mundo entraram em declínio. Os pensadores do novo século passaram a acreditar que o sistema desenvolvido por Descartes não era mais capaz de "assegurar o domínio da realidade" (CHÂTELET, 1974, P.13). Do conhecimento pelas idéias inatas ${ }^{45}$

\footnotetext{
${ }^{45}$ Descartes acredita que de todas as faculdades do conhecer: a imaginação, a inteligência, a memória e os sentidos, apenas a inteligência pode levar à verdade das coisas (BRÉHIER, 1977a, P.57). Seria na própria inteligência que o homem encontraria a verdade. O método
} 
ao homem para o conhecimento pelo mundo que é exterior ao homem, ou seja, pela experiência.

O empirista inglês John Locke, era ums dos pensadores que afirmavam que o conhecimento só poderia ter sua origem nas experiências, opondo-se ao inatismo. Sua obra "Ensaio sobre o entendimento humano", publicado em 1690, inicia-se com a afirmação da inexistência das idéias inatas. Se Deus deu às criaturas o poder de perceber as cores dos objetos que as cercam, como poderia a idéia de cor ser inata ao espírito? (LOCKE, 1952). Assim, o pensador quer provar:

[...] como o homem, somente pelo uso de suas faculdades naturais, pode chegar a todo conhecimento que eles têm, sem a ajuda de qualquer impressão inata; e podem chegar à certeza sem qualquer noção original ou princípios ${ }^{46}$ (LOCKE, 1952, p.95).

Todo o conhecimento pode ser adquirido pelos fenômenos observáveis que se ligariam por correlações também observáveis (DUCHESNEAU, 1974). Sendo assim, o inatismo, que seria a vocação do espírito para relacionar idéias, não poderia existir enquanto operação de correlação. Até as idéias abstratas seriam elaboradas pelo espírito por meio dos dados da

desenvolvido por Descartes vai conduzir essa inteligência para alcançar o conhecimento verdadeiro. A primeira condição do método cartesiano refere-se ao princípio da dúvida. Só se pode considerar alguma coisa como verdadeira se for apresentada ao espírito de forma clara e distinta. Se houver alguma dúvida e respeito sobre essa coisa, ela não pode ser então uma verdade. A segunda condição refere-se à divisibilidade das dificuldades, ou seja, dividir as dificuldades em quantas partes forem necessárias para serem compreendidas melhor. A terceira, conduzir os pensamentos, gradativamente, das idéias mais simples para as mais complexas. A quarta, revisar o todo processo da dúvida metódica para se ter a convicção de que nada foi omitido. Dessa forma, Descartes é levado a duvidar das coisas materiais, da percepção, das experiências e até mesmo das supostas certezas matemáticas. Mas como ter a certeza de que algo está se apresentando de forma clara e distinta? Vita (1968), a respeito de suas considerações sobre Descartes, afirma: "Deus, Ser perfeito e Criador de um mundo de harmonia, introduziu no pensamento as idéias claras e distintas, que uma vez descobertas ou desentranhadas da tela envolvente da matéria, conduzem o homem à certeza." (VITA, 1968, P.55). Isso não significa que as idéias sejam inatas ao espírito, ou seja, que elas estivessem presentes em nossa inteligência. Segundo Bréhier (1977a), "o inatismo das idéias consiste na disposição e, por assim dizer, na vocação que o entendimento tem para pensá-las." (BRÉHIER, 1977a, P. 72).

${ }^{46}$ No original em inglês: "[...] how men, barely by the use of their natural faculties, may attain to all the knowledge they have, without the help of any innate impressions; and may arrive at certainty, without na such original notions or principles." (LOCKE, 1952, p.95). 
experiência, incluindo a idéia de Deus, por exemplo, pois essas idéias nada mais seriam senão reflexões dos fenômenos observáveis. Assim, todas as idéias seriam dados da consciência (mesmo as mais abstratas), tendo suas origens na experiência. Locke ainda afirma que essas idéias, a partir dos dados dos fenômenos observáveis, podem ser formadas na consciência de duas maneiras: pela sensação e pela reflexão.

Todas as idéias vêm da sensação ou reflexão. Vamos então supor que a mente seja, como nós dizemos, um papel em branco, vazio de todos os caracteres, sem qualquer idéia: - Como ele é equipado? De onde vem aquele vasto estoque que a imaginação ocupada e sem limites do homem tem pintado sobre o papel com uma quase infinita variedade? De onde vem todo o material da razão e do conhecimento? Para isso eu respondo, em uma palavra, da EXPERIÊNCIA ${ }^{47}$ (LOCKE, 1952, p.121, tradução nossa).

Pelas sensações, a consciência captaria as impressões do mundo exterior, e pelas reflexões, a consciência conheceria suas próprias operações. As sensações e as reflexões dariam os insumos para que a consciência alcançasse as idéias simples. A partir das correlações que o espírito faz entre as idéias simples, as idéias complexas tomariam forma.

As idéias são formadas em um espírito apenas, ou seja, as idéias se dão para um único sujeito consciente e, para que a comunicação de pensamentos entre os espíritos seja garantida, é necessário que elas sejam transformadas em linguagem. No entanto, a linguagem como instrumento de conhecimento pode se tornar fonte de erros, pois uma palavra pode representar uma determinada idéia para um espírito e para um outro representar uma idéia completamente diferente. Assim, Locke resolve esse

\footnotetext{
${ }^{47}$ No original em inglês: "All ideas come from sensation or reflection. Let us then suppose the mind to be, as we say, white paper, void of all characters, without any ideas: - How comes it to be furnished? Whence comes it by that vast store which the busy and boundless fancy of man has painted on it with an almost endless variety? Whence has it all the materials of reason and knowledge? To this I answer, in one word, from EXPERIENCE" (LOCKE, 1952, p.121).
} 
impasse da seguinte forma: existiriam palavras que se tornariam gerais quando se referirem a idéias gerais. Se elas se tornam gerais, então podem ser representadas para vários indivíduos. Segundo Duchesneau, "pode-se concluir daí que a linguagem é fator constitutivo de nossa concepção abstrata das coisas, que ela nos faz passar da apreensão simples das idéias ao verdadeiro conhecimento e ao saber" (DESCHENEAU, 1974, p.33).

Outro empirista foi George Berkeley. Assim como Locke, ele rejeita o pensamento cartesiano e afirma que o conhecimento só poderia vir dos sentidos. Suas teorias diferem em muitos pontos das de Locke. Enquanto Locke afirma que as idéias são categorizadas em idéias de sensação e idéias de reflexão, Berkeley vai garantir que tal distinção não existe. Para ele não haveria diferença entre a percepção de algo (idéias de reflexão) e a coisa percebida (idéias de sensação). Tudo que o espírito percebe torna-se idéia e, considerando tal indistinção entre elas, também não haveria para Berkeley o conceito de idéias abstratas.

Tal indistinção entre idéias também direciona a uma crítica ao uso da linguagem de Locke. Segundo este, as palavras são uma forma de comunicação e construção do saber. Mas para não conduzir o espírito ao erro, seria necessário torná-las representação de idéias mais gerais. Essa transformação seria um processo de abstração das idéias.

Para Berkeley as idéias abstratas não existem. Elas se apoiariam apenas nas palavras e fariam com que o espírito acreditasse estar pensando em algo, enquanto, na verdade, não se estaria pensando em nada. Só se poderia pensar naquilo que fosse concreto e determinado (ALQUIÉ, 1974, p.44). Assim, a linguagem para Berkeley não se refere a generalizações abstratas como na de Locke. Palavras poderiam ser gerais, não enquanto abstração, mas enquanto idéias particulares. Na verdade, elas se tornariam gerais porque as particularidades foram desprezadas. 
Quando o geômetra raciocina sobre o triângulo, esquece todas as qualidades particulares do triângulo que traçou sobre o quadro. Quando raciocina sobre o círculo, não leva em conta a cor do círculo que imagina. Mas, nem por isso, ele pode representar um círculo sem nenhuma cor: simplesmente ele dirige sua atenção para outra coisa. E há uma grande diferença entre considerar numa linha o comprimento sem a largura e ter a idéia de um comprimento sem largura: a primeira operação é constante; a segunda impossível (ALQUIÉ, 1974, p.45).

O raciocínio de Berkeley sobre as idéias, a abstração e a linguagem, são apenas parte de uma concepção da relação entre sujeito e objeto que vai, de certa forma, distinguir-se do entendimento de Locke. É a teoria do imaterialismo. Locke pensa que as idéias simples podem ser primárias, pertencentes ao próprio objeto, e também podem ser secundárias, qualidades relativas de quem percebe o objeto. Berkeley, no entanto, afirma que as qualidades primárias e secundárias não existem e o que condiciona a relação entre sujeito e objeto é a afirmação "ser é ser percebido".

Berkeley propõe que o objeto só pode existir se ele for percebido por um espírito. Se não existir um espírito que o perceba, então sua existência não pode ser comprovada. E da mesma forma, só seria possível dizer que o espírito existe se ele possuir a capacidade de perceber algo. Assim, Berkeley desconstrói a idéia de matéria, pois a matéria somente existiria enquanto houver um espírito percipiente que a transforme em idéia.

O empirismo, em suas proposições, estaria buscando a origem do conhecimento na experiência sensível e nas operações do espírito sobre esse sensível (DELEUZE, 1974, p.60). David Hume, no entanto, afirma que o conhecimento não pode estar nas idéias formuladas pelo espírito a partir da observação sensível. O conhecimento estaria nas relações que são exteriores às próprias idéias. 
Sobre a idéia de relação em Hume, Deleuze (1974) explica que são operações que fazem o espírito passar de uma idéia ou impressão, que foram fornecidas pela experiência, para a idéia de alguma outra coisa que não foi dada naquele momento. Para Hume, as relações são as únicas coisas constantes e universais para o espírito. Não seria a idéia de algo em si, como Locke afirma ao formular o conceito das idéias abstratas, por exemplo, mas as formas pelas quais se pode passar de uma idéia para a outra. As relações fariam parte da natureza humana e por isso elas conduziriam o espírito ao conhecimento.

Entre as relações que o espírito opera, haveria uma em especial: a causalidade. A relação de causalidade permitiria que o espírito direcionasse a idéia de algo que foi dado pela experiência para a idéia de algo que jamais poderia ser dado por ela. Deleuze assim exemplifica a relação de causalidade:

\begin{abstract}
Ao ver o sol se levantar, digo que se levantará amanhã; tendo visto a água ferver a $100^{\circ}$, digo que ela ferve necessariamente a $100^{\circ}$. Ora, locuções como 'amanhã', 'sempre', 'necessariamente' expressam algo que não pode se dar na experiência: amanhã não é dado nem se tornará hoje, sem cessar de ser amanhã e toda experiência é a de um particular contingente. Em outros termos, a causalidade é uma relação em conformidade com a qual ultrapasso o dado, digo mais que o dado ou dável, em suma, infiro e creio, aguardo, conto com... (DELEUZE, 1974, p.62).
\end{abstract}

Essas proposições só se tornariam possíveis porque "o hábito fortalece a conexão imaginativa que leva o espírito de uma idéia a outra" (BRÉHIER, 1977b, p.96). A imaginação, por meio do hábito, permitiria dizer ao espírito que a água ferve sempre a $100^{\circ}$. E assim, a observação dos dados, o hábito e a imaginação, aliar-se-iam pela relação de causalidade para conduzir o espírito a crer no conhecimento de algo que seria a própria realidade. 
Essas mesmas relações poderiam levar o espírito ao delírio, à loucura, à criação de ficções. O hábito e a imaginação que fariam com que o espírito passasse a crer em determinadas idéias a partir das relações de causalidade. O que daria a certeza ao espírito de que suas crenças não são ficções seriam os princípios próprios da natureza humana que conduziriam as relações. Mas o hábito e a imaginação também poderiam fazer o espírito desviar-se desses princípios, induzindo-o a relações fictícias e, portanto levando-o a um mundo de mentira. É dessa forma que Hume explica a loucura e o delírio não como erros dos espíritos, ou falsas crenças - nesse processo as crenças continuariam sendo verdadeiras para o espírito - mas apenas como ilusão.

A teoria que Hume elabora consegue explicar muitos pontos ainda obscuros do empirismo. A partir das experiências, ou dos dados observáveis, o espírito conseguiria estabelecer relações para construir idéias sobre alguma outra coisa que não viriam dos dados observáveis. Assim, o conhecimento da realidade não estaria nas idéias e sim nas próprias relações que o espírito pode fazer. Diferentemente de Locke, cuja teoria propõe que o conhecimento da realidade seria encontrado nos próprios fenômenos observáveis, e de Berkeley, cuja teoria tinha como premissa para o conhecimento a relação entre perceber e ser percebido, Hume transforma o empirismo na medida em que considera o conhecimento em algo que vem de uma exterioridade que não é coisa ou matéria, mas sim da relação entre idéias.

A corrente empírica influenciou pensadores por vários séculos. Entretanto, de uma forma geral, a experiência para o empirismo resume-se aos dados extraídos do mundo exterior e das sensações e percepções do indivíduo. Esse seria o método pelo qual se poderia chegar ao conhecimento e às idéias das coisas. Conhecimento, portanto, seria um acúmulo de 
experiências e, portanto, poder-se-ia dizer que a experiência seria abordada como algo passado.

A influência da tradição empirista inglesa reverberou em diversas posturas filosóficas durante o século XVIII. No fim do século XIX e início do XX o empirismo ressurgiu sob a forma do pragmatismo. $\mathrm{O}$ contexto histórico era favorável: o progresso das ciências, principalmente das ciências naturais, e o crescimento industrial condicionaram o surgimento da doutrina. No entanto, na visão de Abbagnano (1970), a experiência para o pragmatismo não se referiria aos dados passados como no empirismo do século XVIII e sim uma previsão para o futuro. A experiência adquirida, no pensamento pragmático, conduziria as ações para experiências futuras.

Para o pragmatismo, a experiência é substancialmente abertura para o futuro: uma característica básica será a sua possibilidade de fundamentar uma previsão. A análise da experiência não é portanto o inventário de um patrimônio acumulado mas a antecipação ou previsão do possível desenvolvimento ou utilização deste patrimônio. Deste ponto de vista, uma 'verdade' é-o não porque possa ser confrontada com os dados acumulados da experiência passada mas sim por ser suscetível de um qualquer uso na experiência futura (ABBAGNANO, 1970, p.8).

Charles Sanders Peirce (1839-1914) como lógico dedicou-se ao estudo dos signos, ou semiótica ${ }^{48}$, contribuindo de forma significativa para o campo da comunicação humana. Mas também possui vínculos com a filosofia e o pragmatismo. "O nome de Peirce está intimamente associado ao movimento pragmatista norte-americano. Na filosofia de Peirce, pragmatismo é método para determinação de significados" (MOTA; HAGENBERG, 1975, p.17). Seu ensaio "Como tornar as idéias claras", publicado em 1878, procura investigar os processos do pensamento e com isso expõe seus questionamentos sobre lógica. No entanto, segundo Mota

\footnotetext{
${ }^{48}$ A semiótica também será abordada neste trabalho por sua contribuição teórica nos estudos sobre processos cognitivos.
} 
e Hagenberg (1975), é nesse artigo que o pensador americano lança sua máxima pragmática com a seguinte afirmação:

Considerar que efeitos - imaginavelmente possíveis de alcance prático - concebemos que possa ter o objeto de nossa concepção. A concepção desses efeitos corresponderá ao todo da concepção que tenhamos do objeto (PEIRCE, 1975, p.59).

A lógica de Peirce também vai ressaltar os aspectos pragmáticos. Para explicar como ocorre o processo do pensamento, Peirce afirma: "a ação do pensamento é excitada pela dúvida e cessa com o atingir a crença" (PEIRCE, 1975, p.53) cuja essência estaria na criação de regras de ação ou hábitos de agir que pode ser por meio do estímulo da percepção ou para produzir um efeito sensível (PEIRCE, 1975). Assim, se existe uma idéia sobre alguma coisa é por que se sabe os efeito sensíveis que tal coisa apresentará. Por tal motivo, que Abbagnano (1970) explica o pragmatismo como uma experiência voltada para o futuro. A partir de uma experiência sensível haveria a dúvida sobre algo e, pelo processo de pensamento, hábitos de ação seriam gerados, ou seja, conduzir-se-ia para outras experiências possíveis.

\begin{abstract}
Alguns elementos (as sensações) estão inteiramente presentes durante todos os instantes de sua duração, enquanto outros (como o pensamento) são ações que têm começo, meio e fim e consistem na congruência da sucessão de sensações que atravessam o espírito. Não podem estar imediatamente presentes, mas devem estender-se por alguma porção do passado ou do futuro. $O$ pensamento é um fio de melodia correndo ao longo da sucessão de nossas sensações (PEIRCE, 1975, p. 55).
\end{abstract}

O pragmatismo de Peirce foi seguido por William James (1842-1910). No entanto, se Peirce defendia a concepção de uma idéia como hábito que somente se torna verdadeira no momento em que permite uma ação sobre o real, James coloca o pragmatismo da seguinte forma: 
O método pragmático nesses casos é interpretar cada noção traçando as suas conseqüências práticas respectivas. [...]. Se não pode ser traçada nenhuma diferença prática qualquer, então as alternativas significam praticamente a mesma coisa, e toda disputa é vã. Sempre que uma disputa é séria, devemos estar em condições de mostrar alguma diferença prática que decorra necessariamente de um lado, ou o outro está correto (JAMES, 1979, p.18).

Assim, o pragmatismo de James leva em consideração somente aquilo que pode ter consequências práticas. A corrente pragmática ainda influenciou o pensamento de John Dewey (1959-1952), porém ele denominou sua postura filosófica de instrumentalismo. Suas idéias foram essenciais para a área da educação e da pedagogia nos Estados Unidos. Para a construção de conceitos sobre sistemas para a experiência, suas obras tornam-se instigantes pela construção dada por Dewey sobre a concepção de experiência e sobre como um indivíduo poderia tê-las.

Em sua obra "Arte como experiência", Dewey discorre sobre o conceito de experiência e sobre quais seriam os processos envolvidos para um sujeito de forma ela possa ser caracterizada como tal, pois nem tudo que fosse experimentado poderia ser de fato considerado como experiência. Assim, no capítulo "Como se tem uma experiência" da obra acima citada, o autor afirma que a existência de experiências faria parte da interação do indivíduo com o mundo, mas nem todas as coisas experimentadas resultariam em experiências de fato:

A experiência ocorre continuamente, porque a interação da criatura viva com as condições que a rodeiam está implicada no próprio processo da vida. Sob condições de resistência e conflito, aspectos e elementos do eu e do mundo implicados nessa interação qualificam a experiência com emoções, idéias, de maneira tal que emerge a intenção consciente. Com freqüência, entretanto, a experiência que se tem é incompleta. As coisas são experimentadas, mas não de modo tal que se componham em uma experiência. Há distração; o que observamos e o que pensamos, o que desejamos e o 
que alcançamos, permanecem desirmanados um do outro (DEWEY, 1980, p.89).

Uma experiência teria começo, meio e fim. Seria um fluxo que leva alguma coisa a outra, em um processo contínuo no qual poderia haver "pausas, lugares de descanso, mas elas pontuam e definem a qualidade do movimento" (DEWEY, 1980, p.90). O todo não se perderia com esses intervalos, pois eles representariam momentos nos quais seria possível fazer uma revisão ou absorção do que se passou e, assim, seriam elementos intrínsecos da própria experiência. Portanto, ela seria caracterizada por uma unidade, mesmo que as partes que a constituam sejam diferentes.

Em tais experiências, cada parte sucessiva flui livremente, sem junturas nem vazios, para aquilo que vem a seguir. Ao mesmo tempo, não há sacrifício da identidade própria das partes. (...) Em uma experiência, o fluxo vai de algo a algo. Como uma parte conduz a outra e como outra parte traz aquela que veio antes, cada uma ganha distinção em si própria. O todo permanente é diversificado por fases sucessivas que constituem ênfase de seus variados matizes (DEWEY, 1980, p.90).

Essa experiência, Dewey denomina de consciente. O pensador vai exemplificar o processo através da obra de arte. O artista, quando desenvolve sua arte, passaria por um processo em que relações entre o fazer, o perceber e o sofrer seriam inerentes à produção artística, sendo partes sucessivas de um fluxo contínuo que constituiriam, ao final, uma experiência. Quando essas relações não ocorrem, o fazer, na obra de arte, tornar-se-ia mecânico. "Se o artista não produzir uma nova visão em seu processo de fazer, agirá mecanicamente e repetirá algum antigo modelo fixado como um padrão em sua mente" (DEWEY, 1980, p. 101).

Dewey reflete, mesmo que em poucas linhas, sobre a produção arquitetônica dentro desse processo que leva à experiência. Para o pintor ou o escultor, por exemplo, existiria um processo de retroalimentação da obra em produção. É o que Dewey chamou de fazer, padecer, e perceber o 
próprio processo de produção. No entanto, na arquitetura, esse processo não pode ser realizado de forma tão simples.

Os arquitetos são obrigados a completar suas idéias antes que ocorra a transferência da mesma para um objeto completo de percepção. Essa incapacidade de construir simultaneamente a idéia e seu incorporar-se objetivo impõe uma desvantagem. Não obstante, também eles são obrigados a pensar suas idéias em termos dos meios de incorporação e do objeto da percepção definitiva, a menos que trabalhem mecanicamente e de modo rotineiro. Provavelmente a qualidade estética das catedrais medievais deve-se em parte pelo fato de que suas construções não foram demasiado controladas por plantas e especificações prévias, como se faz hoje em dia (DEWEY, 1980, p.101102).

O pensador dedica-se em explicar e definir o conceito de experiência e tal esforço pode ser enfatizado pela quantidade de livros escritos por ele que tomam como objeto de estudo a experiência. Entre eles estão "Experiência e Natureza" e "Arte como Experiência". O primeiro aponta para o fim dos dualismos que "criam um verdadeiro abismo entre a mente que conhece e o mundo a ser conhecido" (AMARAL, 1990, p. 53) colocando no centro de tudo "a experiência inteligente do homem, a única capaz de alterar o curso dos acontecimentos em função de fins definidos" (AMARAL, 1990, p. 55). O segundo considera a experiência como um fenômeno estético.

Dewey tem aparecido no cenário contemporâneo e com frequência tem sido a referência de designers, arquitetos, pesquisadores que trabalham com o experience design e com o interaction design. Suas reflexões sobre experiência têm sido utilizadas para explicar sobre qual experiência e sob que condições seria possível considerar a existência dela. Shedroff (2005) recorre à definição de experiência de Dewey para enfatizar a necessidade da qualidade da experiência, e no caso específico da área de atuação de Shedroff enquanto designer, para a produção de páginas na internet e desenvolvimento de mídias digitais como CD-ROMs. 
McCarthy e Wright (2004) também adotam a abordagem pragmática, mas para falar da relação entre pessoas e as recentes tecnologias de informação e comunicação. Para os autores, da mesma forma que Dewey coloca uma obra de arte na vida cotidiana das pessoas, criando uma continuidade entre estética e experiência, a tecnologias deveriam ser consideradas como imersas nas experiências cotidianas das pessoas, não apenas em seu sentido funcional e eficiente, mas sob uma perspectiva que abrangesse aspectos afetivos e sensoriais.

Em contraste com outras abordagens filosóficas cujo ponto de partida é a teoria do conhecimento ou estados subjetivos, o pragmatismo começa com a experiência e pelo comprometimento com uma ideologia holística, relacional, tenta assegurar que a experiência nunca é reduzida a categorias como conhecimento, comportamento, ou sentimentos. Para pragmatistas como Dewey, experiência é mais pessoal do que comportamento; ela envolve um eu ativo que não somente toma parte da ação mas também a molda criativamente $^{49}$ (McCARTHY; WRIGHT, 2004, p. 54 tradução nossa).

Para este trabalho, recorre-se ao conceito de experiência elaborado por Dewey. Não porque sua filosofia tem sido encontrada com frequência artigos e livros relacionados com os fenômenos tecnológicos contemporâneos. A experiência para o pragmatismo é considerada como uma instância futura. Dessa forma ações podem conduzir a certas experiências, ou, como no sentido dado por Dewey, como um fluxo de eventos interconectados em um processo contínuo que ao final levaria a uma experiência. Essa formulação de Dewey sobre como se ter uma experiência concorda com as contribuições de um psicólogo

\footnotetext{
${ }^{49}$ No original em inglês: "In contrast with other philosophical approaches whose starting point is a theory of knowledge or subjective states, pragmatism starts with experience and by committing to a holistic, relational worldview, tries to ensure that experience is never reduced to categories such as knowledge, behavior, or feelings. For pragmatists as Dewey, experience is more personal than behavior; it involves an active self who not only engages in but also creatively shapes action" (MCARTHY; WRIGHT, 2004, p. 54).
} 
contemporâneo chamado Mihaly Csikszentmihalyi, que há décadas estuda sobre meios de se melhorar a qualidade de vida das pessoas.

O psicólogo entende experiência de forma similar a Dewey, como um fluxo de eventos. Entretanto, para melhorar a qualidade de vida das pessoas seria necessário um tipo específico de experiência, que ele chama de experiência potencializada ou otimizada (optimal experience). Csikszentmihalyi (1991) narra a sensação envolvida quando se tem essa experiência:

Todos nós já experimentamos momentos em que, ao invés de sermos esmurrados pelas forças anônimas, nós nos sentimos no controle de nossas ações, mestres de nosso destino. Nas raras ocasiões nas quais isso acontece, nós sentimos um sentido de regojizo, um profundo sentimento de divertimento que é por muito tempo cultivada e que se torna um marco na memória sobre como a vida deveria $\operatorname{ser}^{50}$ (CSIKSZENTMIHALYI, 1991, p. 3, tradução nossa).

O psicólogo ainda afirma que a experiência otimizada não envolve o relaxamento e entretenimento passivo, como assistir televisão, apesar de envolver divertimento. Para se alcançar esse estado, seria preciso esforço, concentração e, geralmente, estar envolvido com atividades que exigem empenho tanto do corpo como da mente.

Csikszentmihalyi desenvolve essa experiência através de conceitos de flow (fluxo). Nas definições do psicólogo, o flow seria o "estado na qual as pessoas estão tão envolvidas em uma atividade na qual nada mais parece importar; a experiência em si é tão agradável que as pessoas farão (a

\footnotetext{
${ }^{50}$ No original em inglês: "Yet we have all experienced times when, instead of being buffeted by anonymous forces, we do feel in control of our actions, master of our fate. On the rare occasions that it happens, we feel a sense of exhilaration, a deep sense of enjoyment that is long cherished and that becomes a landmark in memory for what life should be like" (CSIKSZENTMIHALYI, 1991, p. 3).
} 
atividade) mesmo que com grande custo, pela pura satisfação em fazê-lo" 51 (CSIKSZENTMIHALYI, 1991, p.4). Dessa forma, a experiência se traduz em um fluxo de eventos conscientemente selecionados que proporcionariam uma experiência tão imersiva que dela se extrairia toda a sua potencialidade.

Para se ter uma experiência otimizada, seria preciso que as pessoas participassem de situações ou atividades capazes de criar as condições para que elas possam tê-las. Csikszentmihalyi chama tais atividades de flow activities $^{52}$. Em suas pesquisas, o psicólogo descobriu que esse tipo de atividade "fornecia um senso de descoberta, um sentimento de criatividade de locomoção da pessoa em uma nova realidade. Empurrava a pessoa para altos níveis de performance e a direciona previamente para estados de consciência não imaginados" ${ }^{\prime 53}$ (CSIKSZENTMIHALYI, 1991, p. 74). Assim, atividades que envolvam desafios, descobrimentos e engajamento das pessoas, poderiam ser consideradas como flow activities.

Dewey e Csikszentmihalyi falam de experiências de formas muito parecidas. Ambos apontam para um tipo específico de experiência, que é conseguida por meio de atividades que geralmente envolvem engajamento e desafio para a pessoa, como acontece para o artista de Dewey que, ao realizar sua arte, padece e sofre durante o processo. É nesse sentido que as experiências são entendidas neste trabalho, e sua emergência nos indivíduos é o que se espera da relação do interator com o objeto interativo.

\footnotetext{
${ }^{51}$ No original em inglês: "the state in which people are so involved in an activity that nothing else seems to matter; the experience itself is so enjoyable that people will do it even at great cost, for the sheer sake of doing it." (CSIKSZENTMIHALYI, 1991, p.4)

52 Manteve-se o termo em inglês para não induzir a uma compreensão errônea do termo.

${ }^{53}$ No original em inglês: "[...] It provided a sense of discovery, a creative feeling of transporting the person into a new reality. It pushed the person to higher levels of performance, and led to previously undreamed of states of consciousness" (CSIKSZENTMIHALYI, 1991, p. 74).
} 

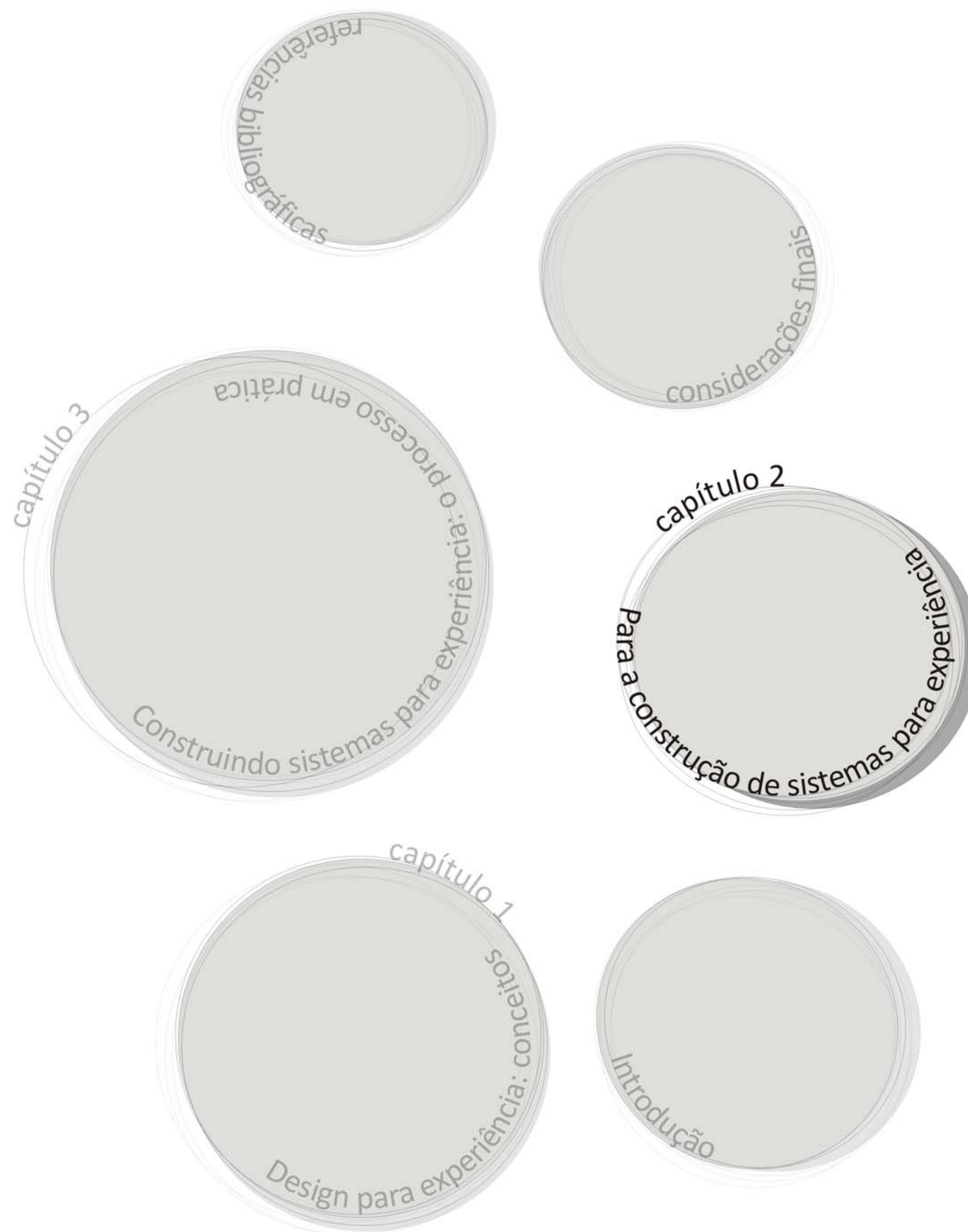

Este capítulo procura apresentar algumas propriedades das relações entre indivíduos e objetos interativos, visando fornecer insumos capazes de auxiliar a ação projetual do designer que pretenda desenvolver proposições segundo o design para experiência. Em outras abordagens de projeto, no design e na arquitetura, tais propriedades podem ser levadas em consideração por arquitetos e designers, porém, possivelmente estarão associadas aos aspectos formais, funcionais e estéticos do produto final. No contexto do design para experiência, essas propriedades não encontrarão na forma, estética ou funcionalidade a finalidade para suas manifestações. Através do entendimento de propriedades particulares da relação indivíduo-objeto, espera-se que o designer tenha condições de explorar certos aspectos envolvidos entre pessoas e objetos interativos, buscando assim os meios para tornar possível o surgimento de experiências.

Essa forma de se colocar frente às relações entre indivíduo o objeto é o ponto de partida para o designer se adotar uma postura quanto às ações projetuais. Assim, o foco desta pesquisa, quando se fala do processo de design, refere-se à forma como essas propriedades serão trabalhadas. A consideração dessas propriedades pelo designer torna-se relevante principalmente para as primeiras considerações sobre a relação indivíduo e objeto com a demarcação do sistema que se quer trabalhar. Mas durante todo o processo de design essas abordagens da relação indivíduo-objeto são exploradas, dotando o sistema da capacidade de se alterar continuamente.

Entretanto, não se pretende fornecer um manual de condutas para ações projetuais a serem seguidas rigorosamente por aqueles que desejam trabalhar com o design para experiência. O intuito é trazer para o designer propriedades relevantes que irão balizar suas posturas frente ao problema a ser enfrentado. Trata-se de auxiliar o designer sobre quais propriedades 
considerar na relação do indivíduo com o objeto interativo e sobre como elas podem se traduzir em ações projetuais.

Este trabalho considera o uso do conceito de sistemas como premissa para o designer que tem como intenção elaborar propostas segundo os princípios envolvidos no design para experiência. Lançar um olhar sistêmico sobre as relações entre os indivíduos e os objetos interativos permite uma abordagem abrangente e flexível. Assim, adota-se aqui a definição de Morin, conforme apresentado no capítulo 1: sistema é uma unidade onde os elementos se organizam para e em um Todo por meio de interações. Dessa organização espera-se a emergência de novas qualidades tanto em relação aos elementos do sistema como para o sistema como um todo.

\subsection{INTERAÇÕES}

Ao considerar o design para experiência sob uma perspectiva sistêmica, o designer passa a trabalhar as relações entre indivíduo e objetos interativos como partes constituintes de um sistema e, dentro desse contexto, tais relações serão denominadas como interações. Para os sistemas, as interações assumem papel imprescindível para a consolidação de um Todo organizado. Na realidade, é por meio das interações entre suas partes que o sistema encontra o potencial para sua organização e com isso permitir o surgimento, ou a emergência, de novas qualidades para o sistema e para os elementos que dele fazem parte. No design para experiência, as experiências são as qualidades emergentes do sistema - lembrando que o que está sendo considerado sobre experiência são as definições dada por Dewey e Csikszentmihalyi.

O desenvolvimento de objetos pelo conceito de interações é abordado pelo interaction design, no qual a relevância do assunto é revelada na própria nominação. Porém, por serem outros os objetivos do interaction design, o 
conceito de interação acaba sendo dotado de outra importância. A idéia de interação ao qual o interaction design recorre pode estar vinculada com o termo utilizado nas áreas dedicadas ao estudo e pesquisa de novas tecnologias de informação e comunicação como as áreas das ciências da computação, por exemplo.

Mas nem sempre a interação foi termo mote para um modelo computacional. De acordo com Dourish (2004), "tradicionalmente, o componente central para qualquer explicação da computação tem sido algoritmos ou procedimentos - modelos baseado em um passo a passo que especificam o comportamento sequencial de um sistema computacional" (DOURISH, 2004, p. 3). No entanto, segundo o autor, nos últimos anos, esse paradigma tem se alterado para um modelo dos fenômenos computacionais pautado na interação dos componentes e não sob um modelo baseado em eventos ou operações sequenciais apenas.

Ainda pelo contexto contemporâneo promovido pelas novas tecnologias de informação e comunicação, Primo (2000) classifica a interação de duas em duas qualidades distintas: como mútua e como reativa. As considerações de Primo sobre a interação restringem-se ao que o autor chama de ambientes informatizados, mas que, na verdade, trata de interfaces gráficas. $\mathrm{O}$ autor define interação mútua como uma relação entre elementos que se desenrola por meio da negociação e nesse processo a ação de um influencia no comportamento do outro e vice-versa. A interação reativa compreende apenas uma relação de estímulo-resposta entre as partes que estão em interação em um processo de ação e reação cuja resposta será sempre a mesma toda vez que a interação se repetir.

Entretanto, Haque (2006a) defende que não haveria interação pautada pela reatividade. Ação e reação não poderiam ser consideradas como um processo interativo. Sendo assim, ele aponta para duas formas de 
interação: de "circuito único" e de "circuito múltiplo" (HAQUE, 2006a). No primeiro caso cada parte em interação agiria conforme um conjunto de regras previamente determinadas. É a mais simples e limitada delas. $\mathrm{O}$ segundo caso refere-se aos "circuitos múltiplos" no qual não se poderia estabelecer uma relação de causalidade clara entre as partes em interação. Portanto, para existir interação seria preciso compreendê-la dentro da idéia de movimento circular e de mão dupla.

\begin{abstract}
Fundamentalmente, interação diz respeito à transmissão de informações entre dois sistemas, por exemplo, entre duas pessoas, entre duas máquinas, ou entre uma pessoa e uma máquina. A chave, porém, é que essa transmissão deverá ser de alguma forma circular, caso contrário, ela será somente "reativa" (HAQUE, 2006a, p. 68).
\end{abstract}

A abordagem dada por Haque sobre a interatividade e as relações com as tecnologias de informação e comunicação estariam mais próximas das teorias dos sistemas do que as considerações feitas por Primo sobre o assunto. Talvez esse fato esteja relacionado com a intimidade do arquiteto com a cibernética e, especificamente, com o pensamento de Gordon Pask no qual ele tem se baseado ao desenvolver suas instalações e eventos.

Segundo Morin, as interações seriam "ações recíprocas que modificam o comportamento ou a natureza de elementos, corpos, objetos, fenômenos em presença ou influência" (MORIN, 2005, p. 72). Por essa descrição entende-se que não seria possível pensar em interações reativas pautadas pelas leis da ação e reação apenas. A interação somente poderia ser considerada como tal caso existam ações mútuas agindo e alterando os elementos do sistema. Mas as interações apenas ocorreriam, dentro de um sistema, em determinadas condições para que elas pudessem se estabelecer. Assim as interações:

1. Supõem elementos, seres ou objetos materiais que podem se encontrar; 
2. Supõem condições de encontro, quer dizer, agitação, turbulência, fluxo contrário, etc.;

3. Obedecem a determinações/imposições ligadas à natureza dos elementos, objetos ou seres que se encontram;

4. Tornam-se, em certas condições, inter-relações (associações, ligações, combinações, comunicações, etc.), ou seja, dão origem a fenômenos de organização (MORIN, 2005, p. 72).

Transpondo essas condições para o estabelecimento das interações nos sistemas para o contexto do design para experiência, algumas considerações podem ser feitas em relação aos itens descritos por Morin. Em primeiro lugar, sistemas pressupõem elementos que interajam. No design para experiência os elementos dos sistemas não podem ser totalmente definidos. Mas eles existem, mesmo não sendo conhecidos pelo designer. No entanto, há pelo menos um deles que é essencial para o sistema: o indivíduo. Ele é pré-requisito para a existência dos sistemas para experiência. Os outros podem ser objetos ou ambientes interativos, interfaces gráficas, ou o que o designer quiser elencar como parte do sistema. Nesses sistemas, adota-se o termo interator para se referir ao indivíduo que atua no sistema.

Em segundo lugar, as condições de encontro podem ser chamadas de contexto. Considera-se também o termo cenário para se referir às condições de encontro desses elementos. A adoção do termo cenário se faz presente, por exemplo, nas considerações de Manzini (2007) sobre a construção de possíveis futuros para modos de vida mais sustentáveis. Para o autor, o designer:

[...] se torna um processo facilitador que age com as ferramentas do design, isto é, pela geração de idéias sobre possíveis soluções, visualizando-as, discutindo-as, colocando-as em cenários abrangentes e diversificados, apresentados em formas participativas potencialmente 
e visualmente concisas $^{54}$ (MANZINI, 2007, p. 15, tradução nossa).

Assim, para Manzini (2007), a construção de cenários é um recurso a ser utilizado no processo de desenvolvimento de objetos, ambientes ou serviços pelos designers. Sua abordagem de cenário refere-se a possíveis proposições para um modo de vida mais sustentável. Para o design para experiência, também se torna recurso a ser utilizado pelo designer na elaboração de suas proposições. Nesta dissertação, compreende-se o termo cenário como as condições necessárias que permitam o encontro entre os elementos do sistema. Não se coloca em termos de espacialidades e sim de situações, podendo englobar considerações sobre o espaço físico, sobre atividades do cotidiano, sobre eventos culturais, entre outras possibilidades.

Em terceiro lugar, considerando que as interações obedeçam a imposições ligadas à natureza dos elementos, o designer, determinando os elementos para o sistema, pode de certa forma, eleger algumas propriedades a serem exploradas para que haja interação entre eles. Entretanto, sendo um dos elementos do sistema impreterivelmente um indivíduo - ou um grupo de indivíduos -, entender sua natureza significa investigar e compreender a própria natureza do homem. Apesar do domínio que o designer pode exercer no processo de design, muitas e variadas são as características a serem consideradas e não se espera que o profissional trabalhe com todas elas. No entanto, algumas dessas características podem ser efetivamente exploradas, porém, de forma seletiva como, por exemplo, a percepção humana, a capacidade de comunicação e de memorização. O designer, no seu processo de design, pode e deve trabalhar sobre determinadas faculdades e capacidades dos seres humanos, mas também deve estar

\footnotetext{
${ }^{54}$ No original: "He becomes a process facilitator who acts with design tools i.e. by generating ideas on possible solutions, visualizing them, arguing them through, placing them in wide, many faceted scenarios presented in concise, visual and potentially participatory forms" (MANZINI, 2007, p. 15).
} 
ciente de suas limitações enquanto projetista e entender que mesmo considerando-as ele não possui o controle total sobre essas propriedades visto que, além de tudo, o homem também é um ser imprevisível.

Tal imprevisibilidade dos seres humanos, contudo, não contraria as formulações de Morin a respeito das condições para a construção de interações, pois o conceito de sistema também trabalha ao nível da probabilidade, do desequilíbrio e da incerteza. A idéia de desequilíbrio é abordada por Bertalanffy (1977) em relação aos sistemas abertos ${ }^{55}$. Em sua concepção, todo sistema aberto precisa do desequilíbrio, pois "uma perturbação no sistema conduz à introdução de um novo estado estacionário" (BERTALANFFY, 1977, p.100) mantendo o sistema em funcionamento. Organismos vivos, como o homem, por exemplo, são sistemas abertos que precisam do desequilíbrio para se manterem e Bertalanffy (1977) vai aplicar isso tanto para aspectos biológicos como para os psíquicos.

\begin{abstract}
A chegada ao equilíbrio significa a morte e consequente decomposição. Psicologicamente, o comportamento não somente tende a libertar tensões, mas também a criar tensões. Se este processo pára, o paciente é um cadáver mental em decomposição, da mesma maneira que o organismo vivo torna-se um corpo ou decomposição quando as tensões e as forças que o conservavam fora do equilíbrio vêm a cessar (BERTALANFFY, 1977, p.254).
\end{abstract}

Os sistemas para experiência são sistemas abertos em sua essência. Considerando o ser humano como parte impreterível dos sistemas, a condição de abertura é dada por consequência. Sendo abertos, os sistemas permitem a entrada de outros elementos e com propriedades variadas, levando-os para uma condição de instabilidade e desequilíbrio. E por essa

\footnotetext{
55 Por sistema fechado Bertalanffy considera aqueles que estão isolados, ou seja, não permitem trocas com o ambiente. Como, por exemplo, substâncias químicas reunidas em um recipiente que não permite troca com o exterior.
} 
característica, a probabilidade das interações acontecerem se tornam maiores.

Em quarto lugar, as interações entre elementos possibilitam novas formas de organização do sistema e delas novas propriedades e qualidade surgem para os elementos e para o sistema como um todo. As experiências podem ser consideradas como as novas qualidades que emergem das interações, dentro do contexto do design para experiência. Mas não se trata de toda e qualquer experiência. A idéia de experiência neste trabalho é compreendida conceitualmente pelas investigações de Dewey e Csikszentmihalyi (conforme comentado anteriormente), como um tipo específico de experiências: as otimizadas.

\subsection{PERCEPÇÃO SENSORIAL}

O designer, munido da capacidade de articular e trabalhar com os processos perceptivos, pode explorar características e propriedades da relação entre indivíduo e objetos interativos, estimulando determinados aspectos sensoriais nessas relações. A partir de tais propriedades, as interações entre os elementos podem se consolidar, pelo menos momentaneamente, visto que o sistema está sempre se alterando e formando novas interações. Assim, espera-se que experiências possam emergir para cada indivíduo ou interator do sistema. Sobre a importância da incitação dos sentidos do homem pelo design, Schifferstein e Spence (2008) afirmam o seguinte:

[...] todos os sentidos humanos contribuem para o modo como um produto é experimentado sendo, portanto, importante considerá-los no processo de design. Compreender os papéis que diferentes sentidos desempenham nas interações das pessoas com produtos pode ajudar os designers a escolher o melhor canal sensitivo para se comunicar uma determinada 
mensagem ao consumidor ${ }^{56}$ (SCHIFFERSTEIN; SPENCE, 2008, p.137).

Shedroff (2005) também aponta para a importância dos processos perceptivos para o design, mais especificamente para o experience design. Segundo o autor, a compreensão dos sentidos humanos pelos designers pode contribuir para a construção de novas experiências ${ }^{57}$ para o espectador ou público para o qual o produto do experience design é desenvolvido. No entanto, a percepção sensorial trabalha aspectos muito pessoais de cada indivíduo, de forma que Shedroff sugere que o designer a explore elaborando uma taxonomia dos sentidos, conforme as considerações que eles desejam fazer sobre os fenômenos perceptivos.

Uma forma de entender como os sentidos podem ser usados nas experiências é construir uma taxonomia e povoá-la com suas [dos designers] próprias opiniões. Visto que nossos sentidos são tão íntimos e parte de nós, eles tendem a ser difíceis de traduzir para os outros. Isso significa conduzir uma exploração mais completa não somente das nossas próprias reações aos sentidos, mas também das reações dos outros ${ }^{58}$ (SHEDROFF, 2005, p. 244, tradução nossa).

Não se pretende, neste trabalho, construir uma taxonomia dos sentidos, mas indicar algumas possibilidades com as quais o designer possa se equipar para trabalhar sobre aspectos referentes à percepção humana,

\footnotetext{
56 No original em inglês: "[...] all of the human senses contribute to how a product is experienced and are, therefore, important to consider in the design process. Insight into the roles that the different senses play in people's interactions with products can help designers to choose the optimum sensory channel by which to communicate a certain message to consumer" (SCHIFFERSTEIN; SPENCE, 2008, p. 137).

${ }^{57}$ Utiliza-se o termo "construção de novas experiências", pois, segundo a visão de Shedroff sobre o experience design apresentado em seu livro de mesmo título, as experiências podem sim ser projetadas. Entretanto, a concepção de experiência adotada nesta Dissertação de Mestrado não admite que elas sejam desenhadas. As experiências, neste trabalho, são entendidas como o produto final da ação promovida pelos conceitos do design para experiência que emergem das interações entre os indivíduos e objetos ou ambientes. Portanto, não podem ser projetadas, mas é possível fornecer os insumos necessários para que elas se constituam.

${ }^{58}$ No original em inglês: "One way to understand how senses can be used in experiences is to build a taxonomy and populate it with your own opinions. Since our senses are such an intimate and immediate part of us, they tend to be difficult to translate to others. This means conducting a more thorough exploration of not only our own reactions to senses, but the reactions of others as well"' (SHEDROFF, 2005, p. 244).
} 
como forma de aumentar a probabilidade de ocorrerem interações nos sistemas para experiência. Dessa forma, apresenta-se, mesmo que brevemente, o que este trabalho considera como percepção e os tipos de percepção a serem investigados.

Os fenômenos perceptivos têm sido objeto de estudo de pensadores e pesquisadores de vários campos disciplinares, em épocas distintas. Não se pretende construir um panorama histórico dessa faculdade humana, mas algumas considerações podem ser feitas sobre o assunto. Na filosofia de Locke, por exemplo, a percepção é tratada como um problema epistemológico. O que os sentidos captam do contato com o mundo que é exterior ao homem formam idéias como vermelho, amarelo, quente, frio, amargo, doce, entre outras. O filósofo inglês chama essa forma de se ter idéias sobre as coisas como sensação, e afirma que "a alma começa a ter idéias quando ela começa a perceber" ${ }^{\prime 59}$ (LOCKE, 1952, p. 123, tradução nossa).

Já a moderna psicologia $\operatorname{cognitiva}^{60}$ entende a percepção como um problema de cognição. Segundo Anderson (2000), a psicologia cognitiva tem como objetivo "entender a natureza da inteligência humana e como ela trabalha"61 (ANDERSON, 2000, p. 1, tradução nossa). Dessa forma, a abordagem da percepção humana recai sobre como a informação captada pelos sensores biológicos do homem são processadas no cérebro e como as pessoas conseguem selecionar, dentre os milhões de dados que os sensores

\footnotetext{
${ }^{59}$ No original em inglês: "[t]he soul begins to have ideas when it begins to perceive" (LOCKE, 1952, p. 123).

${ }^{60}$ A psicologia cognitiva possui vínculos estreitos com a ciência cognitiva, sendo que esta envolve pesquisas em filosofia, psicologia, lingüística, inteligência artificial e neurociência. Para Anderson não é possível estabelecer onde termina o campo de uma e começa a outra, mas a primeira utiliza como método as técnicas experimentais do comportamento humano para entender como a mente funciona e a segunda baseia-se em simulações por computador dos processos cognitivos (ANDERSON, 2000).

${ }^{61}$ No original em inglês: "[...] to understand the nature of human intelligence and how it works" (ANDERSON, 2000, p. 1).
} 
ou receptores captam e que chegam de forma contínua ao cérebro, quais são as informações mais relevantes.

Para o desenvolvimento de proposições segundo os conceitos do design para experiência podem ser explorados processos perceptivos ligados aos cinco sentidos do tato, do paladar, do olfato, da visão e da audição. Alguns pesquisadores ainda consideram outras formas de percepção. Assim, existiriam também a propriopercepção, ou seja, a percepção do próprio corpo (SONNEVELD; SCHIFFERSTEIN, 2008), a cinestesia, referente à percepção do corpo em movimento (SHEDROFF, 2005; SONNEVELD; SCHIFFERSTEIN, 2008; VERNON; 1974), a percepção de outras pessoas, pelas expressões físicas que cada um realiza (VERNON; 1974). No entanto, de certa forma, esses outros tipos de percepção estão vinculadas aos cinco sentidos principais. Por exemplo, a percepção do corpo estaria ligada ao tato (SONNEVELD; SCHIFFERSTEIN, 2008), a percepção de pessoas estaria ligadas à visão (VERNON, 1974), e a percepção de movimento (neste caso não do próprio movimento, mas de outras pessoas ou objetos) que poderia ser ocorrer tanto pela visão (VERNON, 1974) como pela percepção tátil (SONNEVELD; SCHIFFERSTEIN, 2008).

Pela sensação tátil podemos sentir propriedades inerentes aos objetos como peso, textura, temperatura, forma, tamanho, volume entre outras características de cada objeto. Sonneveld e Schiferstein (2008) categorizam essas propriedades em substância (do que o material é feito); superfície (textura e padrões); estrutura (aspectos relacionados à forma, volume e peso); e partes em movimento (como as partes dos objetos se relacionam com outras). Além dessas propriedades, pode-se adquirir pelo contato com os objetos outras sensações como pressão, vibração, temperatura, dor, entre outras. 
A percepção tátil não se reduz ao que é captado pelas mãos apenas. Todo o corpo está envolvido nessa operação por meio de receptores diversos disposto na pele (SONNEVELD; SCHIFFERSTEIN, 2008). Ackerman (2005) refere-se a essa cobertura que recobre o corpo como uma "bolha", sendo que algumas partes são mais sensíveis que outras.

As pontas dos dedos e a língua são mais sensíveis que do que as costas. Algumas partes do corpo são sensíveis a cócegas, e outras respondem quando nos coçamos, trememos, ou sentimos arrepios. As partes de maior concentração de pelos no corpo são as mais sensíveis à pressão, porque há muitos receptores na raiz de cada pêlo ${ }^{62}$ (ACKERMAN, 1995, p. 68, tradução nossa).

A tatilidade possui uma característica que talvez seja mais marcante nessa do que em outras formas de percepção. Cada primeiro contato com algo, ou a cada alteração em relação ao que está sendo sentido provoca uma agitação no processamento da informação, focando a atenção para a nova sensação. A constância, entretanto, leva os receptores a um estado entediante e com isso o foco sai dessa sensação e passa a agir sobre outra forma de percepção. "Uma pressão constante consistente é registrada na primeira vez, ativando os receptores do toque; então os receptores param de trabalhar"63 (ACKERMAN, 1995, p. 80, tradução nossa).

Já o paladar é um dos sentidos que talvez mais esteja enraizado com a cultura e o contexto local. Segundo Ackerman (1995) é uma das formas perceptivas mais intimas que existem. Não se pode experimentar coisas à distância (ACKERMAN, 1995, p. 128). Assim como também não é possível sentir a pressão, a temperatura e a textura das coisas remotamente por meio do tato.

\footnotetext{
${ }^{62}$ No original em inglês: "The fingerprints and tongue are much more sensitive than the back. Some parts of the body are ticklish, and others respond when we itch, shiver, or get gooseflesh. The hairiest parts of the body are generally the most sensitive to pressure, because there are many sense receptors at the base of each hair (ACKERMAN, 1995, p. 68). ${ }^{63}$ No original em inglês: "A constant consistent pressure registers at first, activating the touch receptors; then the receptors stop working" (ACKERMAN, 1995, p. 80),
} 
Para o designer talvez seja o sentido mais difícil de ser trabalhado. Entretanto, em uma exposição chamada Sensorium realizada no List Visual Arts Center do MIT, o arquiteto François Roche e seus parceiros do escritório R\&Sie(n), Stéphanie Lavaux e Jean Navarro, sugerem uma provocação às pessoas pelo paladar. $\mathrm{O}$ trio propõe um bar, chamado por eles de MI(pi) Bar na qual a água utilizada seria proveniente da urina coletada nos banheiros do MIT e filtrada por uma máquina de ozônio e/ou um filtro de cerâmica. A proposta aponta para vários questionamentos, como a sustentabilidade. Mas sobre a percepção, o que os arquitetos investigam é quanto o gosto da água pode ser alterado ao saber de onde vem a água, por mais pura e límpida ela seja.

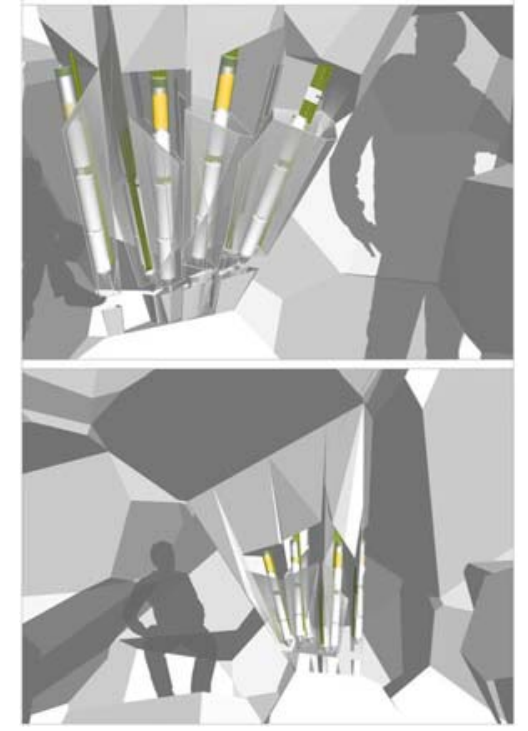

Figura 2.1: Interior dos banheiros com o sistema de coleta (R\&SIE(N), 2007).

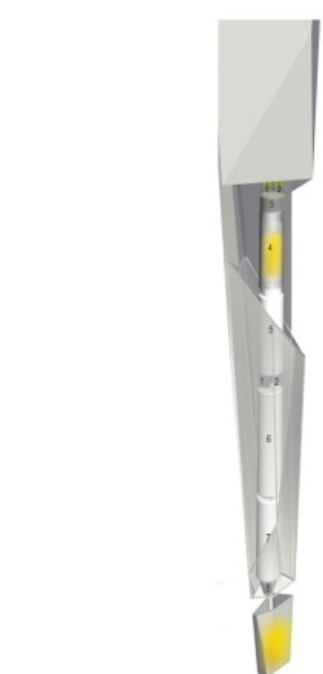

Figura 2.2: Sistema para coleta e purificação da urina (R\&SIE(N), 2007).

O olfato é um sentido que foi relegado pela Filosofia Moderna enquanto problema epistemológico (JONES, 2006). Entre todos os sentidos está posicionado no nível mais baixo quando colocado como uma questão relacionada ao conhecimento e aos processos do pensamento. No entanto, diferentemente de outros sentidos da percepção humana, é o único que estará sempre presente em qualquer condição por estar vinculado à respiração. 
Nós só vemos quando há luz suficiente, degustamos apenas quando colocamos coisas na boca, tocamos quando fazemos contato com alguém ou com algo, ouvimos somente sons que são altos o suficiente. Mas nós sentimos odores sempre e a cada respiração ${ }^{64}$ (ACKERMAN, 1995, p. 6, tradução nossa).

Jones (2006) questiona a condição de rebaixamento desse sentido em relação aos outros, devido ao fato de muitos pensadores e filósofos, ao menos desde a Era Moderna, o considerarem como um sentido sem linguagem. Para o autor, o olfato teria encontrado sua pior posição no limpo cubo branco e inodoro do Movimento Moderno (JONES, 2006, p.14). No entanto, ao mesmo tempo em que existe uma repulsa em relação a este sentido, existe um fascínio por ele. Este é o sentido que está mais intensamente ligado ao processo cognitivo da memória. O caráter nostálgico que o olfato remete torna-se tão relevante para a memória que Ackerman chega a afirmar que "quando damos um perfume para alguém, estamos dando memória liquida"65 (ACKERMAN, 1995, p. 11, tradução nossa).

Nenhum outro (sentido) se comunica tão
imediatamente e diretamente com as áreas da
memória no cérebro, contornando a cognição
consciente para ressaltar o emocional; estados
associados às combinações químicas do instante em
que o neurônio específico para aquele odor foi
primeiramente estimulado ${ }^{66}$ (JONES, 2006, p. 13,
tradução nossa).

A indústria aromática, no entanto, tem explorado de diversas formas o olfato. De vinhos a perfumes e cosméticos em geral, esse sentido

\footnotetext{
${ }^{64}$ No original em inglês: "We only see when there is enough light, taste only when we out things into our mouths, touch when we make contact with someone or something, hear only sounds that are loud enough. But we smell always and with every breath" (ACKERMAN, 1995, p. 6).

${ }^{65}$ No original em inglês: "When we give perfume to someone, we give them liquid memory" (ACKERMAN, 1995, p. 11).

${ }^{66}$ No original em inglês: "[...] None other communicates so immediately and directly to the site of memory in the brain, bypassing conscious cognition to summon core emotional; states associated with the minute chemical combinations that first stimulated the neuron for that specific scent" (JONES, 2006, p. 13).
} 
representa alto potencial de exploração. Em relação às tecnologias digitais de processamento de dados, os odores também começam a fazer parte das pesquisas de empresas vinculadas ao setor. Um exemplo é um equipamento chamado Aromageur. Trata-se de um aparelho com vários frascos de fragrâncias em seu interior. Conectado a um computador, o usuário combina as fragrâncias para a formação de odores diversos por meio de uma interface gráfica. Apesar se representar uma exploração da tecnologia sem o devido questionamento sobre sua inserção no cotidiano, o Aromageur conta com o diferencial de trabalhar a percepção através do olfato.

A visão é um dos sentidos mais importantes para os seres humanos, impondo-se sobre outros sentidos (ACKERMAN,1995). O alcance da visão é muito maior do que o dos outros sentidos. No toque e no paladar é necessário que a coisa a ser percebida esteja em contato fisicamente com o sistema perceptivo. No olfato, é necessária certa proximidade para se sentir odores. Na visão, o único condicionante é a existência ou não de luminosidade suficiente para que o sistema da percepção visual seja excitado. $\mathrm{O}$ alcance é dado por aquilo que ele consegue captar, mesmo em relação às coisas mais distante fisicamente.

A psicologia cognitiva se preocupa em entender como se dão os processos de reconhecimento visual, ou seja, como o homem consegue processar e identificar aquilo que está sendo captado por seus sensores. Existem alguns modelos para explicar esse processo. No modelo por correspondência (template-matching model) entende-se que as pessoas teriam um repertório de padrões acumulados e talvez formado pela experiência. Ao receberem um estímulo visual, ocorreria um processo no qual, para cada estímulo recebido, uma busca nos padrões existentes seria realizada, até que houvesse correspondência entre estímulo e padrão. Há ainda outro modelo mais refinado e se refere à análise das propriedades dos objetos 
(feature analysis). Nesse modelo, estímulos visuais seriam entendidos como combinações de propriedades. Cada objeto possuiria determinadas propriedades que o caracterizariam como tal e assim ele poderia ser reconhecido. A teoria do reconhecimento por componentes (recognitionby-components theory) defende a idéia de que os objetos podem ser decompostos em partes mais simples. Isso explicaria como as pessoas conseguem fazer a distinção entre objetos diferentes, como entre um homem e um cavalo, por exemplo.

Não por acaso, muitos dos ambientes, instalações e objetos interativos recorrem aos estímulos visuais para estabelecer uma relação com o indivíduo. O Memory Wall é um desses ambientes. Projetado pelos arquitetos Jason Bruges e Kathryn Findlay e instalado no hotel Puerta America de Madrid, possui sensores que conseguem captar as cores predominantes das roupas das pessoas que se encontrem no espaço. As informações captadas são transformadas em sinais e decodificadas na forma de padrões luminosos nas paredes desse ambiente.

Egmond (2008) classifica o processo perceptivo da audição em três níveis: sons da fala, sons musicais e sons do ambiente. Essas três qualidades não seriam excludentes entre si havendo, portanto, sons que poderiam ser classificados em mais de uma categoria. "Nesses casos, o contexto no qual o som é ouvido será o fator determinante para relacioná-lo a um domínio específico" $^{67}$ (EGMOND, 2008, p. 71, tradução nossa).

Do ponto de vista da psicologia cognitiva, fazer o reconhecimento auditivo é mais complexo do que o visual, principalmente quando se trata do reconhecimento da fala, ou seja, reconhecer a linguagem envolvida no processo de audição. Em experimentos feitos por pesquisadores, foi verificada a dificuldade humana em ouvir várias pessoas falando ao mesmo

\footnotetext{
${ }^{67}$ No original em inglês: "In these cases the context in which the sound is heard will be the determinant factor to relate it to a specific domain" (EGMOND, 2008, p. 71).
} 
tempo. Assim foi desenvolvida a teoria do filtro, cujo princípio básico é que "a informação sensorial avança através do sistema até que algum tipo de gargalo seja alcançado”68 (ANDERSON, 2000, p.76, tradução nossa). Assim, como em todo processo perceptivo, a audição envolve a seleção das informações que serão trabalhadas pelo processo cognitivo dos seres humanos.

No design de produtos em geral, os profissionais estão mais preocupados em tornar determinado produto mais silencioso (EGMOND, 2008). Mas é possível explorar a atividade sonora dos objetos, embora muitas vezes essa propriedade esteja vinculada com sinais de alerta, como buzinas e despertadores.

Existe ainda um processo chamado de paralelismo na percepção humana, ou seja, é possível processar informações oriundas de diferentes sistemas perceptivos ao mesmo tempo. O paralelismo não ocorre a todo momento, nem envolvendo todos os sentidos. No entanto, esse fenômeno presente no processo perceptivo não ocorre em todos os outros processos cognitivos, principalmente quando se trata do sistema motor. Embora os seres humanos possam realizar vários movimentos diferentes, alguns são difíceis de serem executados simultaneamente.

Esse paralelismo pode ser confundido com sinestesia, mas, no entanto, trata-se de aspectos muito diferentes relacionados à percepção humana. Enquanto o paralelismo é uma característica do sistema perceptivo, a sinestesia não representaria um processo comum e poucas seriam as pessoas dotadas de tal capacidade. Cytowic (1989) afirma que a sinestesia:

[...] é uma junção involuntária na qual a informação real de um dos sentidos é acompanhada por uma percepção em outro sentido. Além de ser involuntária,

\footnotetext{
${ }^{68}$ No original em inglês: "[...] sensory information comes through the system until some bottleneck is reached" (ANDERSON, 2000, p. 76).
} 
essa percepção adicional é considerada pelo individuo que a possui como sendo real, frequentemente fora do corpo, ao invés de imaginada ${ }^{69}$ (CYTOWIC,1989, p. 1, tradução nossa).

Apesar de a sinestesia ser um fenômeno ligado a uma capacidade preceptiva peculiar de poucos indivíduos, o designer pode trabalhar seu objeto de proposição de forma sinestésica. A textura para pisos molhados desenhadas pelo designer Arnout Visser pode ser interpretado como um exemplo da exploração pelo design dos aspectos sinestésicos, mas de forma a propor uma confusão perceptiva intencional para o indivíduo. O piso possui uma textura que a primeira vista remete a um piso molhado, ou seja, remete à idéia de uma superfície que desliza, escorregadia e perigosa. No entanto, a textura do piso funciona como um antiderrapante, justamente no sentido contrário da aparência sugerida.

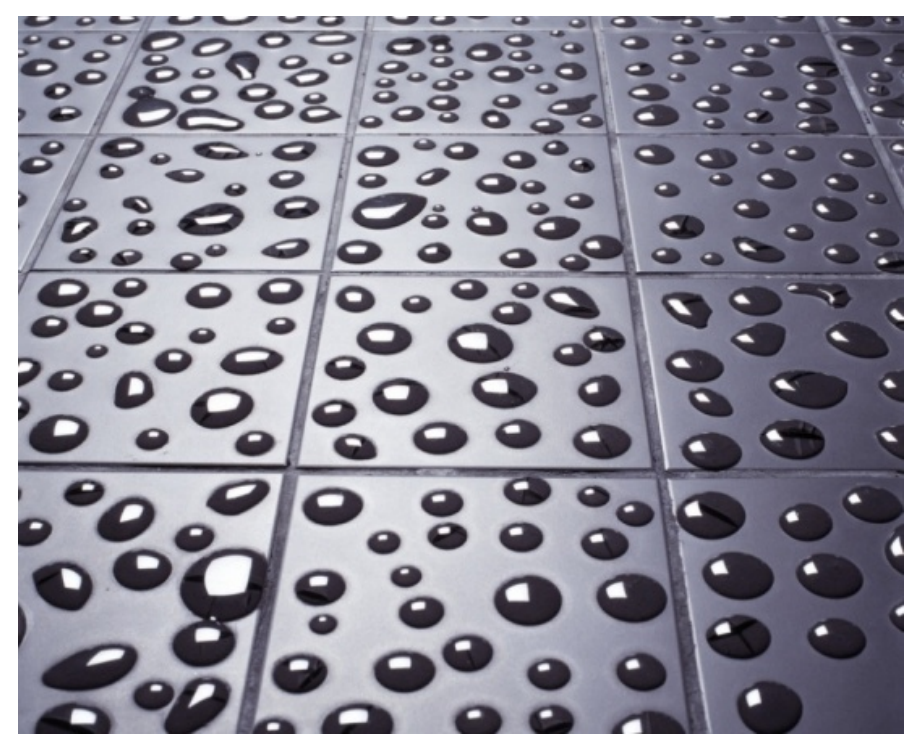

Figura 2.3: Textura antiderrapante para piso de Arnoult Visser (VISSER, 2001).

O processo perceptivo é dependente de outro fenômeno cognitivo chamado de atenção. Por ela, o indivíduo seleciona as informações que

\footnotetext{
${ }^{69}$ No original em inglês: "[...] is an involuntary joining in which the real information of one of the senses is accompanied by a perception in another sense. In addition to being involuntary, this additional perception is regarded by the synesthete as real, often outside the body, instead of imagined in the mind's eye" (CYTOWIC,1989, p. 1,).
} 
considera relevantes entre as muitas que ele recebe de forma contínua por seu sistema perceptivo. "Mecanismos de atenção seletiva permitem que as pessoas se concentrem num evento particular de interesse em seus ambientes e que elas evitem um sobrecarregamento sensitivo" ${ }^{\prime 70}$ (SCHIFFERSTEIN; SPENCE, 2008. p. 139, tradução nossa). Na psicologia cognitiva, Anderson apresenta o problema da atenção da seguinte forma:

Bilhões de neurônios estão processando a informação dos sentidos e entregando o que eles encontram para os mais avançados centros do cérebro. Esse enorme sistema de processamento da informação cria um problema para a cognição de alto nível, que é decidir com o que se ocupar em relação a todas as informações provenientes dos sentidos que estão sendo processadas ${ }^{71}$ (ANDERSON, 2000, p. 36, tradução nossa).

O problema cognitivo da atenção torna-se essencial para o conceito do flow e para a experiência otimizada desenvolvida Csikszentmihalyi (1991). Para entender o problema da atenção pelos conceitos do flow é necessário recorrer ao que o psicólogo define como "anatomia da consciência". O homem possui a capacidade de processar as informações que recebe e respondê-las de acordo. Tudo o que o sujeito experimenta seriam eventos na consciência nos quais as informações podem ser manipuladas e usadas. Dessa forma a consciência pode ser pensada como "informação intencionalmente ordenada" (CSIKSZENTMIHALYI, 1991, p.26). No entanto, para manter as informações de forma ordenada na consciência seria necessária uma força que Csikszentmihalyi chama de "intenções".

As intenções chegam à consciência sempre que a pessoa está consciente de desejar algo ou de querer concluir algo. Intenções são também bits de informação, moldados tanto por necessidades

\footnotetext{
${ }^{70}$ No original em inglês: "Mechanisms of selective attention allow people to concentrate on particular events of interest in their environments and to avoid sensory overloaded." (SCHIFFERSTEIN; SPENCE, 2008. p. 139).

71 No original em inglês: "Billions of neurons are processing sensory information and delivering what they find to the higher centers in the brain. This enourmous informationprocessing system creates a problem for higher-level cognition, which is to decide what to attend to from all the sensory information being processed."(ANDERSON, 2000, p. 36,).
} 
biológicas ou por objetivos sociais internalizados. Eles agem como campos magnéticos, movendo a atenção na direção de alguns objetos e se afastando-a de outros, mantendo a mente concentrada em certos estímulos em preferência a outros ${ }^{72}$ (CSIKSZENTMIHALYI, 1991, p.27, tradução nossa).

As intenções traçam os objetivos que o sujeito estabelece ao interagir com o objeto. Porém, como as informações são ordenadas para que as intenções sejam alcançadas? O psicólogo desenvolve então a idéia da "atenção". A atenção é um processo de seleção de "bits de informação" relevantes dentre uma enorme quantidade de informação disponível na consciência. É uma energia aplicada que Csikszentmihalyi chama de energia psíquica. Quando o sujeito foca sua atenção para uma intenção ou objetivo, ele entraria em um estado de concentração e controle da informação no qual a consciência permaneceria ordenada (CSIKSZENTMIHALYI, 1991).

Da mesma forma que seria possível ordenar a consciência para se alcançar objetivos determinados, ela também poderia entrar em desordem, num processo de entropia psíquica no qual a informação entraria em conflito com as intenções. Nessas situações surgiriam distrações, ansiedade e medo, por exemplo, e a energia psíquica seria perdida, pois os objetivos ou intenções não teriam sido alcançados.

Para explorar a atenção nos processos perceptivos, Ackerman (1995) afirma que é necessário submeter os sensores humanos a novos estímulos. Dessa forma, a atenção recairia em novas informações recebidas pelos sensores biológicos do homem. Sobre a importância do fenômeno da atenção, Ackerman explica que:

\footnotetext{
72 No original em inglês: "Intentions arise in consciousness whenever a person is aware of desiring something or wanting to accomplish something. Intentions are also bits of information, shaped either by biological needs or by internalized social goals. They act as magnetic fields, moving attention toward some objects and away from others, keeping our mind focused on some stimuli in preference to others" (CSIKSZENTMIHALYI, 1991, p.27).
} 
Nossos sentidos também suplicam por novidade. Qualquer alteração os alerta e eles enviam um sinal para o cérebro. Se não há mudança, ou novidade, eles cochilam e pouco ou nada registram. [...]. Então é não apenas possível, mas também inevitável que uma pessoa vá crescer acostumada com o barulho da cidade e sua perturbação visual e não registre esses estímulos constantemente. Por outro lado, a novidade em si mesma sempre fixa a atenção. Existe aquele momento único quando alguém se confronta com algo novo e um assombramento se inicia (ACKERMAN, 1995, p. 304, tradução nossa) ${ }^{73}$.

Designers podem explorar a questão da novidade com a alteração dos estímulos, tanto em intensidade como sobre qual sensor eles vão atuar. Essas alterações podem direcionar o foco para determinadas atividades pelo processo da atenção e com isso permitir que os indivíduos permaneçam mais envolvidos nelas. Como conseqüência, as interações podem tornar-se mais intensas, potencializando as condições para a emergência de experiências.

\subsection{CONSTRUÇÃO E RESGATE DE MEMÓRIA: SIGNIFICADOS ASSOCIADOS}

A exploração da percepção sensorial é uma das propriedades na relação indivíduo e objeto interativo para a construção de interações fortes nos sistemas. Mas existem outras possibilidades associadas aos processos perceptivos e à atenção seletiva que podem contribuir para a consolidação das interações e, portanto, para a formação de experiências. Trata-se de uma exploração dos aspectos relacionados à memória humana. O designer, ciente de como os processos cognitivos vinculados à memória se

\footnotetext{
${ }^{73}$ No original em inglês: "Our senses also crave novelty. Any change alerts them, and they send a signal to the brain. If there's no change, no novelty, they doze and register little or nothing. [...]. So it is not only possible but inevitable that a person will grow used to a city's noises and visual commotion and not register these stimuli constantly. On the other hand, novelty itself will always rivet one's attention. There is that unique moment when one confronts something new and astonishment begins" (ACKERMAN, 1995, p. 304).
} 
desenrolam na mente humana, pode articular vários elementos do sistema de forma a conduzir os indivíduos para uma melhor retenção dos eventos desencadeados nos sistemas com o intuito de fortalecer as relações entre do individuo com o objeto interativo.

Alguns pesquisadores e profissionais da área do design têm sugerido e feito uso de aspectos derivados do estudo da memória humana em suas proposições teóricas e práticas. Norman (1988) aproxima a psicologia cognitiva com o design sob a perspectiva da usabilidade. Um dos pontos ressaltados pelo psicólogo é a consideração da memória humana como dado de projeto. Porém, balizando-se sempre pelas questões do uso dos objetos no cotidiano, o psicólogo recorre aos estudos sobre a memória como um critério de projeto para facilitar as ações das pessoas em relação a um objeto.

O designer, para Norman (1988), deveria se preocupar em projetar produtos que não exigissem muito da capacidade das pessoas de armazenarem informações na memória. Diminuir o número de ações e comandos que uma pessoa precisa fazer para colocar um produto em funcionamento seria uma das metas a serem alcançadas pelos seguidores dos métodos da usabilidade. Evitar extensos manuais operacionais ou colocar regras para a manipulação no próprio objeto são algumas das práticas sugeridas por essa abordagem no design.

Os métodos da usabilidade são utilizados pelo interaction design enquanto disciplina vinculada às ciências da computação. Nesse caso, aplicam-se os estudos sobre a memória da mesma forma defendida por Norman (1988). Entretanto, o enfoque do interaction design está em facilitar o uso em relação aos produtos eletrônicos com tecnologias de informação e comunicação ou ainda para tornar a navegação em páginas na internet ou em CD-ROMs mais simples e prazerosas. Sharp, Rogers e Preece (2007) 
explicam os objetivos de se trabalhar com a memória em produtos com processamento digital:

Memorabilidade refere-se à facilidade em se lembrar de como usar um produto, uma vez que se tenha aprendido. Isso é especialmente importante para produtos interativos que são usados com pouca frequência. Se usuários não usaram uma operação por alguns meses ou mais, eles deveriam ser capazes de se lembrar ou, pelo menos, ser rapidamente lembrados de como usá-lo. Usuários não deveriam precisar reaprender como realizar tarefas ${ }^{74}$ (SHARP; ROGERS; PREECE, 2007, p. 23, tradução nossa).

Mas existem outras formas de se tratar a questão da memória pelo design. Uma delas procura envolver o indivíduo de forma mais afetiva do que efetiva com o objeto com o qual ele está em contato. O designer, nessas proposições, tende a trabalhar com o resgate de memórias ou dotar o objeto de características que conduzirão uma pessoa a estabelecer fortes vínculos com ele. Mugge, Schoormans e Schifferstein (2008) sugerem que "[...] designers podem influenciar os vínculos emocionais entre consumidores e seus bens encorajando as memórias associadas com um

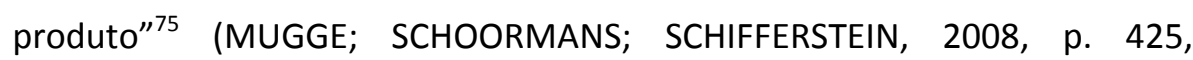
tradução nossa). No entanto, essa forma de se trabalhar os aspectos da memória não garante o sucesso da abordagem, afinal envolve condicionantes como o contexto, as memórias passadas das pessoas e o interesse que elas podem assumir frente ao produto.

Neste trabalho não se toma partido nem por uma abordagem, nem por outra. Procura-se determinar suas próprias considerações sobre o assunto. Assim, entende-se que os estudos sobre memória podem auxiliar o

\footnotetext{
${ }^{74}$ No original em inglês: "Memorability refers to how easy a product is to remember how to use, once learned. This is specially important for interactive products that are used infrequently. If users haven't used an operation for a few months or longer, they should be able to remember or at least rapidly be reminded how to use it. Users shouldn't have to keep relearning how to carry out tasks" (SHARP; ROGERS; PREECE, 2007, p. 23).

${ }^{75}$ No original em inglês: "[...] we suggest that designers can influence the emotional bond between consumers and their durables by encouraging the memories associated with a product" (MUGGE; SCHOORMANS; SCHIFFERSTEIN, 2008, p. 425).
} 
designer a adotar ações mais conscientes em relação às propriedades a serem exploradas na relação entre pessoas e objeto interativos de forma a estimular e fortalecer as interações. $O$ intuito de se trabalhar com as questões sobre memória está em dotar o designer da capacidade de elaborar ou explorar as informações que os indivíduos recebem por meio de seu sistema perceptivo de forma que elas tendam a permanecer na memória. Trata-se, portanto, de tentar instruir os indivíduos do sistema a consolidarem determinadas informações em sua memória.

Recorre-se novamente à psicologia cognitiva para entender como essa disciplina estuda os processos vinculados à memória e quais os modelos mais frequentes do funcionamento dessa capacidade. A psicologia cognitiva descreve dois tipos de memória: uma de curto prazo e uma de longo prazo. A memória de curto prazo possuiria uma capacidade de reter informação por um período curto de tempo, e sua capacidade de armazenamento também não permitiria grandes quantidades de informação. Miller (1956) sugere que a capacidade de reter informações na memória de curto prazo giraria em torno de sete palavras ou números ou "pacotes" de informação com uma diferença de duas unidades para mais ou para menos.

Há ainda um modelo para a memória de curto prazo que a coloca como um estágio intermediário até que a informação seja transferida para a memória de longo prazo por meio da repetição. Esse modelo é questionado por muitos (ANDERSON, 2000) pois, embora a memória de curto prazo explique os fenômenos ligados ao esquecimento rápido de determinada informação, ela não poderia ser considerada como uma ante-sala da informação, que depois migraria para a memória de longo prazo. Segundo Anderson (2000), pesquisas estariam sugerindo que as informações poderiam ir diretamente para a memória de longo prazo, sem necessariamente passar pela memória de curto prazo. Explorar aspectos da memória de curto prazo, contudo, não traria contribuições tão relevantes para os sistemas para experiência, já que 
o interesse do design para experiência sobre a memória é como as pessoas armazenam determinadas informações e como elas recuperam e criam novas relações conceituais e conhecimento por meio do conteúdo já existente e permanente na memória das pessoas.

Uma das questões que os estudos sobre memória se ocupam em entender refere-se ao processo de codificação da informação por representações baseadas no significado. Esses estudos sugerem que a mente humana memoriza com mais facilidade quando ela consegue associar significados às informações. Existiriam dois tipos de modelos baseados no significado das coisas (ANDERSON, 2000). Um deles é denominado de "estruturas propositivas" que codificam informação significante sobre algum evento. $\mathrm{O}$ outro modelo é chamado de "esquemas" que classificam eventos e objetos conforme suas propriedades típicas.

As representações por estruturas propositivas afirmam que as informações apreendidas do mundo exterior e as inferências que se pode fazer delas seriam organizadas em unidades dotadas de significado próprio e quando, articuladas entre si, formariam estruturas mais complexas. Segundo Anderson, o conceito de proposição viria da linguística e referir-se-ia à "menor unidade de conhecimento que pode ser sustentada como uma asserção separada; ou seja, a menor unidade sobre a qual faz sentido construir um julgamento de verdadeiro ou falso" ${ }^{76}$ (ANDERSON, 2000, p. 145 , tradução nossa). Alguns pesquisadores sugerem que as proposições seriam como os nós de uma rede e ao considerar alguns nós dessa rede seria possível construir asserções sobre algum conceito ou sobre alguma coisa.

\footnotetext{
${ }^{76}$ No original em inglês: "[...] the smallest unit of knowledge that can stand as a separate assertion; that is, the smallest unit about which it makes sense to make the judgment true or false" (ANDERSON, 2000, p. 145).
} 
O modelo dos esquemas sugere que as informações sobre algo seriam armazenadas em categorias, em nichos que se referenciariam a diversos atributos. Anderson fornece um exemplo para que se possa compreender como funcionaria esse modelo dos esquemas. Quando se pensa em "casa" vários elementos a esse conceito estão associados, como, por exemplo materialidade, dimensões, funcionalidade, forma, entre outras informações - a recorrência e a frequência com que esses conceitos aparecem relacionados entre si poderiam sugerir a existência de modelos desse tipo.

Esses esquemas também poderiam ser aplicados para eventos, existindo uma série de condutas a serem seguidas em relação a determinadas situações, por exemplo, ir a um cinema ou a um restaurante. Existiriam ações seqüenciais para cada um desses eventos que permitiriam categorizálos como "ir ao cinema" e "ir ao restaurante". Essa extensão do modelo dos esquemas para eventos é chamado de roteiro ${ }^{77}$ (ANDERSON, 2000).

Norman (1988) considera todos esses modelos como variações de uma mesma proposta que entende o processamento da informação na mente humana como uma complexa rede de associações. Esses modelos talvez não sejam os únicos e são apenas representações abstratas de como funcionaria o processamento da informação na mente. A ciência cognitiva, por exemplo, também trabalha com a idéia de redes como modelo para a mente humana, mas através de outros modelos. Pensa o funcionamento do cérebro pelo esforço em tentar compreender como pode o homem desenvolver alto nível cognitivo conectando a unidade física básica do cérebro, os neurônios (ANDERSON, 2000). Esse modelo é chamado de conexionismo, redes neurais ou modelos mentais (NORMAN, 1988). Tomando como base esses modelos sobre como as informações são processadas, pode-se ter um breve entendimento sobre como a memória humana funciona.

\footnotetext{
77 Em inglês, o modelo do roteiro é denominado de script associando-o aos roteiros cinematográficos.
} 
Procurar compreender os modelos descritos acima é necessários para se entender os acessos à memória. A teoria da ativação procura compreender como as pessoas conseguem se lembrar de determinadas informações na memória de longo prazo. Uma das idéias trabalhadas por pesquisadores envolve os modelos da estrutura do pensamento em rede. Ao se lembrar de determinada informação, a pessoa automaticamente se lembraria de outras relacionadas com ela. "A ativação espalha-se através de uma rede de itens apresentados para ativar memórias associadas"78 (ANDERSON, 2000, p. 186, tradução nossa). No entanto, a recuperação de certas informações e, por conseguinte, de todas as outras relacionadas, dependeriam do quão enraizadas estão essas informações na memória. Pela prática, as informações poderiam se fixar com mais intensidade na memória. Seria como se a prática fosse marcando com mais força o caminho para se chegar a determinada informação e com isso sua recuperação se daria de forma rápida e fácil.

Com essas considerações sobre os processos relacionados com a memória humana pode-se neste momento estabelecer as relações com o design para experiência. Norman relaciona as memórias de longo prazo com as experiências. $O$ termo experiência que o psicólogo usa refere-se àquilo que se apreende através dos sentidos, portanto, numa definição distinta daquela considerada nos conceitos de experiência desenvolvidos pode Dewey e Csikszentmihalyi e que este trabalho adota como conceito fundamental. No entanto, a seguinte explanação pode elucidar vários pontos relevantes para este trabalho:

A memória de longo prazo é a memória para o passado. Como uma regra, leva um tempo para estocar coisas na memória e tempo e esforço para elas saírem novamente. Isso é como nós mantemos nossas experiências, não como gravação exata dos eventos, mas como interpretado por meio de nossas compreensões sobre eles, sujeitas a todas as distorções

\footnotetext{
${ }^{78}$ No original em inglês: "Activation spreads through a network from presented items to activate associated memories" (ANDERSON, 2000, p. 186).
} 
e mudanças que o mecanismo humano de explanação impõe sobre a vida. O quão bem nós podemos recuperar experiências e conhecimento da memória de longo prazo, depende altamente de como o material foi interpretado pela primeira vez ${ }^{79}$ (NORMAN, 1988, p. 67, tradução nossa).

As memórias seriam mais facilmente armazenadas quando associadas a um significado. Atribuindo significado às informações recebidas por meio dos sensores biológicos do homem ou mesmo construindo conceitos e conhecimento sobre algo pela associação de significados implicaria na retenção da informação na memória de longo prazo. Com isso, de acordo com Norman, as experiências poderiam ser mantidas na memória. No entanto, a forma como as informações são armazenadas dependeria de como essas informações são apreendidas pela primeira vez por um indivíduo. Nesse momento as associações por significado tornam-se crucias para como o indivíduo vai reter essas informações.

O designer pode auxiliar na construção desses significados. Anderson (2000) apresenta um experimento no qual sentenças significativas sugeridas pelos pesquisadores se mostraram mais eficientes para a recuperação da memória em relação às sentenças propostas pelas próprias pessoas. Esse experimento era formado por quatro grupos de pessoas. Para cada grupo foi dada uma sentença para ser memorizada. Em um grupo, as pessoas receberam apenas a sentença. Em outro, os pesquisadores solicitaram às pessoas que associassem outras informações que as fizessem recordar da sentença. No terceiro grupo, os pesquisadores forneceram um aditivo impreciso que em nada acrescentava à sentença principal. No quarto, os pesquisadores forneceram outras informações adicionais, mas contribuindo

\footnotetext{
${ }^{79}$ No original em inglês: "Long-term memory is memory for the past. As a rule, it takes time to put stuff away in LTM and time and effort to get it out again. This is how we maintain our experiences, not as an exact recording of the events, but as interpreted through our understandings of them, subject to all the distortions and changes that the human explanatory mechanism imposes upon life. How well we can ever recover experiences and knowledge from LTM is highly dependent upon how the material was interpreted in the first place" (NORMAN, 1988, p. 67).
} 
com a informação da sentença principal. Esse estudo demonstrou que o grupo que recebeu a sentença e informações adicionais pelos pesquisadores foi o que obteve a maior porcentagem de pessoas que conseguiram se lembrar dela. Porcentagem esta que foi maior mesmo quando solicitado às pessoas que elaborassem suas próprias relações na sentença. Isso indicaria o potencial do designer para a construção de significados para auxiliar nesse processo.

Sugere-se assim trabalhar com processos de significação para a construção de memórias provenientes das relações entre indivíduos, abordando princípios da semiótica. E para a consolidação dessas memórias, recorre-se para as teorias da aprendizagem baseadas em narrativas.

Csikszentmihalyi e Rochberg-Halton (1981) também trabalham com o processo de significação envolvido na relação do indivíduo com o objeto. Os pesquisadores estudaram o significado que as pessoas davam aos objetos de seus ambientes domésticos. Para tal, procuraram fazer suas considerações sobre o que seriam os signos, que para os autores assumem o mesmo sentido de símbolo:

Dizer que significação é um processo de comunicação envolvendo signos levanta a questão: o que se entende por "signos"? Aparentemente, artefatos materiais são as coisas mais concretas que nos cercam em nossas casas: nós podemos apontar para eles, olhá-los, tocálos, sentar sobre alguns deles, às vezes nós até trombamos com eles e forçadamente nos lembramos de sua materialidade. Alguém poderia imaginar que os signos ou símbolos referem-se somente a coisas como crucifixos, troféus, diplomas, ou alianças de casamento, cujas principais funções - se é que eles, de fato, têm alguma - é representar alguma coisa como religião, conquistas ou relacionamentos. [...] Mas e outros tipos de objetos que parecem ter funções mais bem definidas, como o aparelho de televisão ou o mobiliário? Essas coisas também se qualificam como "signos"? De nossa perspectiva elas podem fornecer 
tantos significados quanto o crucifixo ou o troféu $^{80}$ (CSIKSZENTMIHALYI; ROCHBERG-HALTON, 1981, p. 20, tradução nossa).

Assim, todos os objetos do espaço doméstico possuiriam um significado, construído pela própria pessoa. “Quando uma coisa 'significa algo' para alguém, isso é interpretado no contexto de experiências passadas, sejam elas conscientes ou inconscientes na forma do hábito" ${ }^{81}$ (CSIKSZENTMIHALYI; ROCHBERG-HALTON, 1981, p. 21). Ou seja, é no cabedal de experiências que o indivíduo vai acumulando que o processo de significação seria construído. Cherry (1971) concorda com os autores ao:

[...] considerar qualquer indivíduo como um conjunto específico de experiências, isto é, de experiências comunicativas, que lhe foram comunicadas, no nascimento, por seus pais e antepassados, ou coletadas durante seu curso de vida. [...] A interpretação de um signo, a reação suscitada em algum individuo, depende, pois, da acumulação especifica de experiências que esse indivíduo compreende (CHERRY, 1971. p.401).

Mas o que é um signo de fato e como se dão os processos de significação? A semiótica, também conhecida como teoria dos signos, ocupa-se dessas questões. Para Peirce, "um signo, ou representâmen, é aquilo que, sob certo aspecto ou modo, representa algo para alguém" (PEIRCE, 1999, p. 46). Esse algo do qual fala o pensador americano seria o objeto a que esse signo

\footnotetext{
${ }^{80}$ No original em inglês: "To say that meaning is a process of communication involving signs raises the question: What is meant by "signs"? Apparently, material artifacts are the most concrete things that surround us in our homes: We can point to them, look at them, touch them, sit on some of them, sometimes we even bump into them and thus are forceably reminded of their materiality. One might wonder if signs or symbols refer only to things as crucifixes, trophies, diplomas, or wedding rings, whose main function - if they, indeed, have any - is to represent something like religion, achievements, or relationships. A wedding ring on someone's hand, for example, is a sign of attachment, just as a trophy tells of its winner's prowess and the family's pride in displaying it. But what about other types of objects that seen to have a more clear-cut function, such as a television sets or furniture? Do these things also qualify as "signs"? From our perspective they can provide just as many meanings as a crucifix or trophy" (CSIKSZENTMIHALYI; ROCHBERG-HALTON, 1981, p. 20).

${ }^{81}$ No original em inglês: "When a thing "means something" to someone, it is interpreted in the context of past experiences, either consciously, or unconsciously in the form of habit" (CSIKSZENTMIHALYI; ROCHBERG-HALTON, 1981, p. 21).
} 
se refere. O signo nada mais seria do que a representação desse objeto e apenas isso, ou seja, ele não é o seu objeto.

Cherry (1971), ao falar da semiótica peirciana, vai afirmar que há um usuário implicado nesse processo, colocando-o em uma posição triangular em relação ao signo e ao seu objeto. Essa relação triádica, no entanto, não seria com um indivíduo. O que ele chama de indivíduo, é o que Peirce denomina de interpretante. Não seria uma pessoa em si, mas sim um processo de semantização de signos - mas que realmente só poderia existir em um indivíduo. E o interpretante também pode se tornar um outro signo mais desenvolvido e assim em diante estabelecendo uma cadeia de pensamentos.

A relevância de uma aproximação semiótica no desenvolvimento das relações entre indivíduos e objetos se dá pela exploração de signos diversos, provocando no indivíduo que interage com os objetos um processo de significação contínua. O recurso da semiótica não é novidade para aqueles que trabalham com design. Dunne (2005), sobre o design de produtos eletrônicos nos anos 1980 afirma:

A semântica e a semiótica foram originalmente usadas por linguístas para compreender a estrutura da linguagem e como ela se converte em significado [...] Em design elas foram usadas para analisar os modos como a forma poderia ser usada para expressar significados implícitos ${ }^{82}$ (DUNNE, 2005, p.26, tradução nossa).

\footnotetext{
82 No original em inglês: "Semantics and semiotics were originally used by linguists to understand the structure of language and how it conveys meaning [...]. In design they were used to analyze the way form could be used to express implicit meanings" (DUNNE, 2005, p.26).
} 


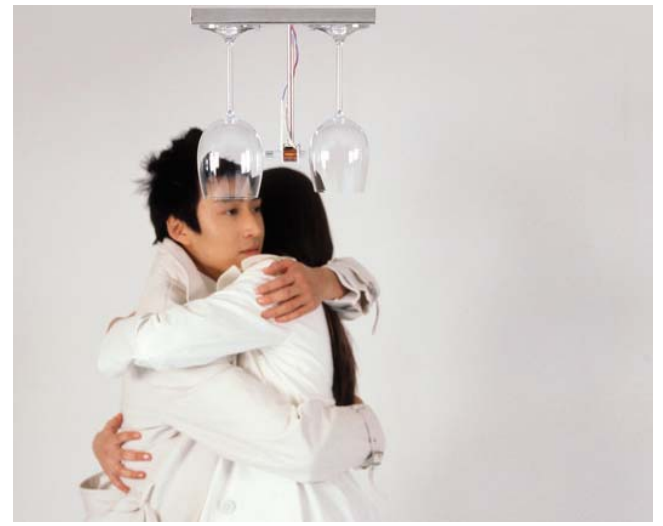

Figura 2.4: Bottoms up doorbell de Peter van der Jagt (JAGT, 1994).

O objeto Bottoms up doorbell de Peter van der Jagt pode ser considerado dentro da abordagem pela semiótica. É uma campainha para portas cujo sistema é composto por taças e um pequeno martelo que ao tocar no vidro produz um som. O processo de significação parte da forma, mas envolve também o som provocado pelo toque do martelo nas taças. Esse objeto remete aos eventos festivos e cada vez que a campainha é acionada, significa que está se considerando a chegada de alguém como uma festa digna de brindes.

\subsection{COMUNICAÇÃO}

Os itens abordados anteriormente neste capítulo contam com a questão da comunicação inserida sob vários aspectos. Na percepção sensorial, a recepção de estímulos vindos de qualquer um dos sensores biológicos significa a transmissão de uma mensagem. A forma como as informações são armazenadas também envolvem os processos de significação associados a essa capacidade humana, configurando-se como assunto também vinculado com as teorias sobre comunicação. A semiótica, utilizada pelo designer como um recurso para a compreensão do processo de significação a ser aplicado nos sistemas para experiência, também trabalha dentro do campo de atuação da comunicação.

No entanto, o que foi apresentado nos itens anteriores aborda questões da comunicação enquanto capacidade dos seres humanos para apreender e processar informações. Os assuntos afins com os processos de comunicação 
restringiam-se em compreender os fenômenos da apreensão e processamento da informação para o indivíduo apenas, sem atentar para as formas de transmissão da informação.

Portanto, pretende-se discutir neste item, os meios pelos quais as informações podem ser transmitidas entre pessoas. Trata-se de uma abordagem a respeito das tecnologias de informação e comunicação como mediadores das relações comunicativas entre os indivíduos de um sistema. Desse ponto de vista, a comunicação é explorada por um nível mais sintático e nem tanto pelo semântico ou pragmático, como de certa forma se fez nos itens anteriores deste capítulo.

Para entender a questão sintática adotada neste tópico, faz-se necessário uma breve consideração sobre a comunicação por seus aspectos lógicos, ou semióticos, conforme apontado por Cherry (1971). A lógica da comunicação envolve três níveis de estudos: o sintático, o semântico e o pragmático. 0 nível pragmático é o mais abrangente dos três. Aborda "todos os fatores pessoais, psicológicos, que distinguem um evento de comunicação" (CHERRY, 1971). O nível semântico trata das relações entre os signos e aquilo a que ele se refere. Ambos os níveis estão presentes na discussão realizada nos tópicos sobre memória e percepção. O terceiro nível ocupa-se apenas das relações entre os signos apenas, sendo, portanto um cálculo no qual os problemas semânticos não são relevantes para esse nível de abordagem.

Este tópico toma como ponto de partida para as considerações sobre as TIC como mediadores das relações comunicativas entre pessoas o modelo para a transmissão da informação desenvolvida por Shannon (1948) no artigo $A$ mathematical theory of communication, para a área das telecomunicações. Apesar de se considerar neste item a comunicação entre pessoas apenas, e não entre pessoas e máquinas ou ainda somente entre máquinas, entende- 
se que o modelo de Shannon, embora seja restrito aos aparatos técnicos apenas, funciona como base para os esquemas de comunicação. Assim, o objetivo é recorrer a esse modelo de comunicação enquanto estrutura e nos elementos que dele fazem parte para elaborar os próprios modelos a serem explorados pelo designer. O modelo de um sistema de comunicação é representado da seguinte forma pelo engenheiro:

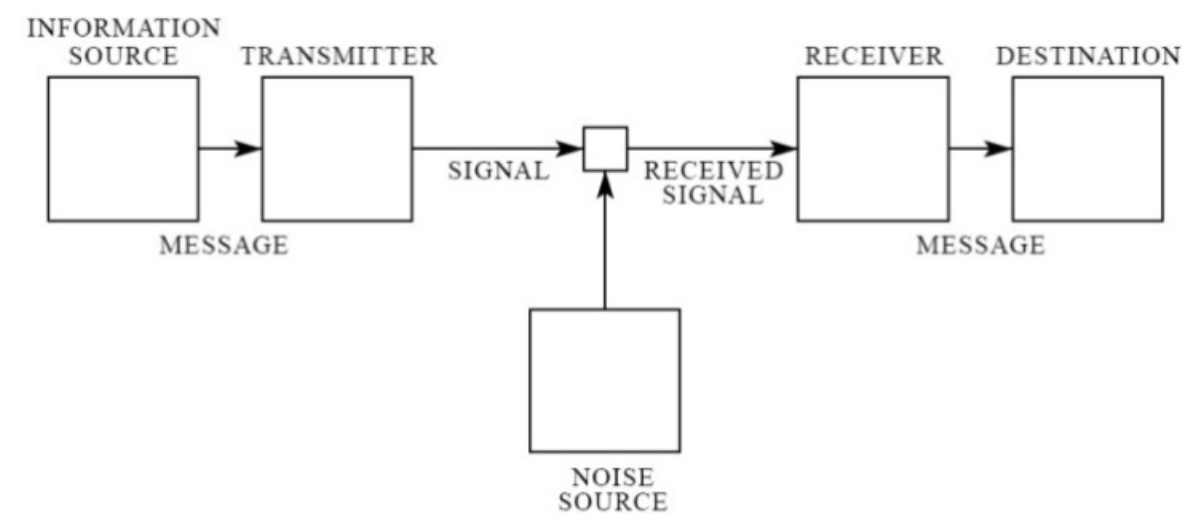

Figura 2.5: Esquema geral para um sistema de comunicação. (SHANNON, 1948).

Nesse esquema do sistema de comunicação, Shannon contempla tanto os elementos do sistema como também as relações entre eles. A fonte (information source) "produz uma mensagem ou sequência de mensagens a serem comunicadas para um terminal receptor" ${ }^{\prime 83}$ (SHANNON, 1948, p. 2, tradução nossa). 0 transmissor (transmitter) "opera sobre a mensagem de alguma forma para produzir um sinal adequado para transmissão sobre o canal” $^{\prime 4}$ (SHANNON, 1948, p. 2, tradução nossa). O transmissor, também chamado de codificador, transforma a mensagem em um sinal, conforme o meio ou o canal. O canal é "o meio usado para transmitir o sinal do transmissor para o receptor" ${ }^{\prime 85}$ (SHANNON, 1948, p. 2, tradução nossa). Berlo (1972) estabelece três sentidos para o canal: como modos de codificação e decodificação das mensagens (ele não codifica, mas pode

83 No original em inglês: "[...] produces a message or sequence of messages to be communicated to the receiving terminal" (SHANNON, 1948, p.2).

${ }^{84}$ No original em inglês: "[...] operates on the message in some way to produce signal suitable for transmission over the channel" (SHANNON, 1948, p.2).

${ }^{85}$ No original em inglês: "[...] the medium used to transmit the signal from transmitter to receiver" (SHANNON, 1948, p.2). 
determinar em que tipo de sinal a mensagem será transformada), como veículos da mensagem e como transportadores dos veículos, sendo que por veículos Berlo (1972) entende os meios de comunicação em seu sentido comum, ou seja, como a televisão, o rádio, o palco de teatro, entre outros. Sobre os transportadores, Berlo (1972) não se preocupa em explicá-los, mas poderiam ser considerados como as formas com as quais os sinais das mensagens são transmitidos. Ou seja, por ondas de rádio, eletromagnéticas, impulsos elétricos entre outros. O receptor capta o sinal emitido e "executa uma operação inversa daquela feita pelo transmissor, reconstruindo a mensagem pelo sinal" ${ }^{86}$ (SHANNON, 1948, p. 2, tradução nossa), ou seja, o receptor é um decodificador dos sinais. O elemento final do esquema de Shannon é o destinatário (destination), o indivíduo que recebe a mensagem por seu sistema perceptivo.

A partir do esquema para os sistemas de comunicação de Shannon, Berlo (1972) faz seu próprio esquema. O autor descreve os elementos envolvidos no processo de comunicação como: fonte, codificador, mensagem, canal, decodificador e recebedor da informação. Expande esse modelo para a comunicação em sua forma mais abrangente incluindo gestos, diálogos, e até mesmo monólogos visto que é possível para o mesmo indivíduo assumir o papel de emissor e de receptor da mesma mensagem. Em uma situação de comunicação não mediada por uma tecnologia de informação e comunicação, esse modelo poderia ser representado pelo seguinte exemplo: duas pessoas conversando. Uma delas seria a emissora de determinada mensagem. Mas para transmiti-la seria necessário um codificador, que pode ser o sistema vocal, embora os codificadores possam ser vários como gestos, olhares, forma como a pessoa está vestida, enfim, todos esses elementos são codificadores de mensagem. Mas considerandose apenas a mensagem proveniente do sistema vocal do emissor, o canal de transmissão dela seria o ar, com as ondas sonoras. Os decodificadores da

\footnotetext{
${ }^{86}$ No original em inglês: "[...] performs the inverse operation of that done by the transmitter, reconstructing the message from the signal" (SHANNON, 1948, p.2).
} 
mensagem seriam os sensores auditivos do receptor e todo o sistema cognitivo para processamento da informação.

Essa situação exemplifica o modelo de comunicação de forma simplificada. Nesse caso não existe nenhuma tecnologia eletrônica para a transmissão de informação. O que não significa que não exista mediação nessa situação de comunicação. O ar é o meio através do qual as ondas sonoras se propagam e, portanto, o ar é o mediador e o canal. Portanto, a mediação não é um fenômeno ligado apenas aos aparatos eletrônicos. Todo tipo de comunicação é mediada de alguma forma.

O sensorium humano tem sempre sido mediado. (Sem o "meio" do ar ou da água, os ouvidos antropóides se descobrem impossibilitados de ouvir). Mas nessas últimas décadas esta condição tem se intensificado fortemente. Amplificado, protegido, canalizado, simulado, provocado - nosso sensorium é mais mediado hoje do que antes ${ }^{87}$ (JONES, 2006, p. 5, tradução nossa).

Quando Jones (2006) fala que os sentido humanos estão cada vez mais mediados, eles estão mediados pelos aparatos permitidos pelo desenvolvimento das tecnologias de informação e comunicação. E é nesse contexto, do incremento tecnológico, tanto enquanto pesquisa quanto no cotidiano das pessoas, que surgem as teorias da comunicação do ponto de vista matemático, probabilístico e estatístico da informação, entre elas a de Shannon. A preocupação do engenheiro estava em garantir a fidelidade da mensagem que sai do emissor e que chega ao destinatário nos meios eletrônicos de comunicação.

\footnotetext{
${ }^{87}$ No original em inglês: "The human sensorium has always been mediated. (Without the 'medium' of air or water, the anthropoid ear finds it impossible to hear.) But over the past few decades that condition has greatly intensified. Amplified, shielded, channeled, prothestized, simulated, irritated - our sensorium is more mediated today than before" (JONES, 2006, p. 5).
} 
A teoria de Shannon também se ocupava com a presença do ruído nos sistemas de comunicação. A tentativa em dotar esse processo de uma probabilidade estatística e matemática estava em diminuir a presença de interferências ou, como Shannon (1948) denomina, ruídos no sistema, sejam eles no codificador da fonte, no canal ou ainda no decodificador. Tal estudo tinha como intuito aumentar a eficácia na transmissão das mensagens, mantendo a fidelidade à mensagem original. No entanto, $\mathrm{A}$ questão do ruído torna-se relevante nos sistemas para experiência enquanto processo cognitivo da atenção seletiva. Isso significa diminuir as interferências na comunicação de forma que se mantenha a atenção sobre algo e não determinar o quanto de ruído o sistema de comunicação possui em termos matemáticos.

O intuito de se fazer tais considerações sobre a comunicação enquanto nível sintático não envolve cálculos matemáticos. Procura-se tomar o modelo para sistemas de comunicação enquanto base para a elaboração de esquemas possíveis de serem trabalhados pelo designer nos sistemas para experiência. Portanto, os elementos envolvidos na comunicação, ou seja, a fonte, o transmissor/codificador, o canal, o receptor/decodificador e o destinatário servem como um gabarito para que se colocar em minúcias os meios pelos quais os indivíduos podem se comunicar nos sistemas para experiência.

Contudo, o processo de comunicação não pode ser reduzido a esses esquemas. $\mathrm{O}$ que se propõe é uma estratégia para o designer estabelecer relações comunicativas entre os indivíduos de diversas formas, mas isso não significa que o processo deve se limitar a esquemas. Também não se pode considerar cada elemento do modelo de forma isolada dos demais, como também não se pode admitir que a mensagem transmitida seja uma única e sequencial. As mensagens podem ser várias, acontecendo simultaneamente, por canais diferentes e sendo decodificadas por diversos 
aparatos. Conforme Berlo (1972, p. 66), “todos os ingredientes são interligados e interdependentes".

\begin{abstract}
É por demais fácil encarar este ou qualquer outro modelo de comunicação como se fosse um sistema 'automático'. Mas não é assim que a comunicação funciona. Todos os ingredientes e fatores da comunicação, que mencionamos e discutimos, estão entrelaçados. Quando nos lançamos num processo de comunicação, não podemos deixar de lado nenhum deles - ou toda estrutura ruirá (BERLO, 1972, p. 67).
\end{abstract}

Portanto, apesar do designer trabalhar com os processos de comunicação como se fossem partes, deve ele ter ciência de que as relações entre indivíduos e os dispositivos eletrônicos e digitais envolvidos no processo não são unilaterais e nem constituídos por uma única mensagem. A comunicação não ocorre em etapas e nem em partes, mas ocorre de forma contínua. Ao designer é dada a possibilidade de explorar partes do processo comunicativo, mas é dele também a capacidade de reconhecer a abrangência envolvida nesse mesmo processo.

Juntamente com os esquemas a serem explorados pelo designer, propõe-se também considerações sobre o espaço e o tempo para o estabelecimento da comunicação mediada pelas tecnologias de informação e comunicação entre as pessoas. A vida digital tem transformado as relações temporais e espaciais no processo e comunicação entre pessoas (NEGROPONTE, 1995). Simultânea ou em tempos diferenciados, geograficamente remota ou espacialmente localizada, a comunicação mediada por aparatos eletrônicos e digitais têm permitido novas explorações das instâncias espaciais e temporais em relação ao processo de comunicação entre indivíduos.

Castells (2005) aborda a questão da temporalidade dos processos de comunicação mediados pelas recentes tecnologias digitais de informação e comunicação enfatizando seu caráter simultâneo e síncrono. Com isso, desponta-se para a formação de outro entendimento sobre a 
temporalidade, marcado pela simultaneidade, no qual se pode comunicar em tempo real ou receber informações de qualquer lugar do planeta de forma quase instantânea ao evento ocorrido, e pela intemporalidade, marcada pela ausência de começo, fim e sequência do tempo impresso pelas tecnologias digitais.

Entretanto, em um momento anterior às considerações de Castells, Negroponte (1995) enfatizava outro aspecto temporal dos processos de comunicação mediados pelas tecnologias digitais da informação. Negroponte apostava em um futuro dominado pela assincronicidade da comunicação e não pela sincronicidade dela, devido à condição possibilitada pelas novas tecnologias de transmissão de manipulação das mensagens de acordo com o interesse e a necessidade de cada indivíduo. Cada pessoa teria a liberdade de selecionar as mensagens que gostariam de receber, no tempo em que desejassem e as responderiam a qualquer momento, também conforme opções pessoais.

Já Sharp, Rogers e Preece (2007) abordam a comunicação síncrona e assíncrona como possibilidade fornecida pelas novas tecnologias digitais e que, portanto, pode ser explorada (entre as tantas possíveis que as autoras identificam) enquanto comunicação e colaboração em situações relacionadas ao trabalho. Assim, o designer se ocuparia em desenvolver ferramentas de comunicação e colaboração que contemplassem tanto aspectos vinculados à troca de mensagens feita de forma instantânea, quanto a aspectos que não fossem baseados no imediatismo na comunicação entre pessoas.

A questão da espacialidade nos processos de comunicação pode ser tratada sob duas formas: por um lado, pelo desenvolvimento de tecnologias de alcance local. As mensagens enviadas e recebidas compartilham o mesmo local. Por outro lado, com a internet ou outras redes de transmissão de 
dados, é possível explorar a comunicação entre pessoas geograficamente distantes. Conforme Negroponte (1995) afirma, a "vida digital exigirá cada vez menos que você esteja num determinado lugar em determinada hora" (NEGROPONTE, 1995, p. 159).

Sharp, Rogers e Preece (2007) fornecem como exemplo de comunicação que se dá em um local o projeto Dynamo do Interact Lab, da Universidade de Sussex, na Inglaterra. Trata-se de uma interface multiusuário a ser instalada em espaços públicos, como bibliotecas e escolas, ou em espaços que apresentem alta rotatividade de pessoas, como bares e cafés. Essa interface compreende um depositório de arquivos no qual as pessoas podem fazer uploads (depósitos) de seus arquivos ou downloads (cópias) de arquivos postados por outras pessoas.

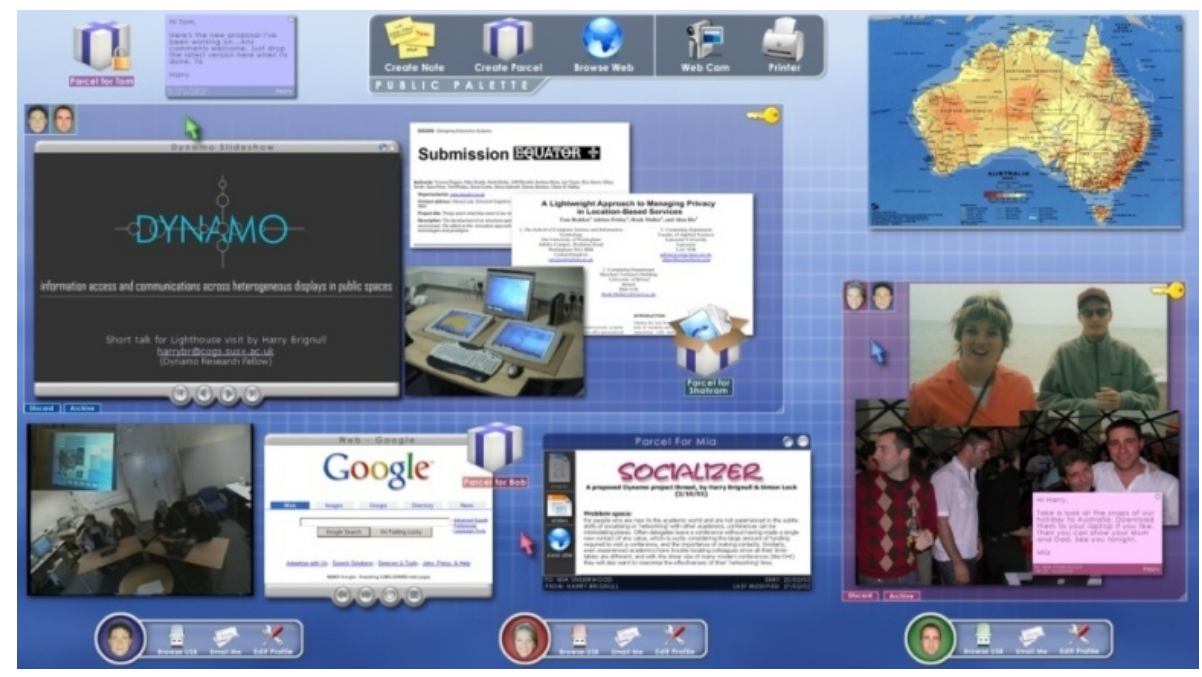

Figura 2.6: Interface multiusuário Dynamo. (INTERACT LAB, 2004)

Da comunicação remota, não se pretende entrar no ânimo provocado pelos questionamentos sobre as possíveis alterações e implicações espaciais geradas pelos fenômenos tecnológicos das últimas décadas. A questão, inclusive, assume várias abordagens como a noção de comunidades virtuais, tele-trabalho, ensino à distância, espaços virtuais, espaços híbridos, entre várias outras aproximações e investigações possíveis. Castells (2005), 
por exemplo, assinala, entre outras considerações sobre a espacialidade, que as transformações do mundo digital e eletrônico desvincularam as atividades cotidianas de espaços determinados.

O desenvolvimento da comunicação eletrônica e dos sistemas de informação propicia uma crescente dissociação entre a proximidade espacial e o desempenho de funções rotineiras: trabalho, compras, entretenimento, assistência à saúde, educação, serviços públicos, governo e assim por diante (CASTELLS, 2005, p. 483).

Ao considerar a comunicação entre regiões geograficamente distantes, este trabalho procura explorar o potencial permitido pelas redes de transmissão de dados como um recurso a ser utilizado pelo designer no desenvolvimento de sistemas para experiência. Sharp, Rogers e Preece (2007) citam ferramentas criadas para as redes e que podem ser apropriadas pelos designers, como os emails, as video-conferências, as salas de bate-papo, os comunicadores instantâneos, os jogos online, entre outras disponíveis. Porém o uso de uma rede de transmissão de dados não envolve apenas as interfaces gráficas desenvolvidas para a internet. Pode-se pensar em objetos que enviem determinada mensagem se utilizando de uma rede de transmissão de dados sem necessariamente passar por um computador pessoal. O micro-controlador do próprio objeto, que não deixa de ser um computador, pode enviar mensagens para outros decodificadores, sendo eles tanto computadores pessoais como qualquer outro aparato eletrônico que consiga decodificar os sinais em mensagens.

Assim, o tempo e o espaço da comunicação podem ser trabalhados da seguinte forma:

1. Comunicação entre pessoas locadas em um mesmo espaço - supõe que a codificação da mensagem em sinal, o canal de transmissão dos sinais, a decodificação novamente do sinal em mensagem aconteça no mesmo espaço; 
2. Comunicação entre lugares geograficamente remotos - supõe que o codificador da mensagem em sinal esteja em um local e o decodificador do sinal novamente em mensagem esteja em outro local;

3. Comunicação síncrona - mensagens sendo enviadas e recebidas simultaneamente ou com pouco atraso entre elas;

4. Comunicação assíncrona - as mensagens enviadas são decodificadas ou recebidas depois de um determinado tempo, longo o suficiente para se retirar a característica de sincronicidade;

É importante ressaltar que, embora se tenha sugerido a abordagem das instâncias de comunicação nesses tópicos, elas não são excludentes e nem estanques. É possível trabalhar com todas as possibilidades em um mesmo aparato eletrônico por exemplo. Se for tomado o exemplo do Dynamo, a interface embora priorize o envio e o recebimento de mensagem no mesmo local, ele possui acesso à internet o que significa permitir a comunicação entre lugares geograficamente remotos, a comunicação síncrona e assíncrona, se considerada a possibilidade dada às pessoas de enviar mensagens por comunicadores instantâneos ou emails e fóruns de discussão, entre outros.

Essas formas de comunicação devem estar associadas aos esquemas que o designer pode explorar. Abaixo estão descritas alguns esquemas para a comunicação:

1. Indivíduo/objeto interativo/indivíduo - considera o objeto interativo como o codificador e ao mesmo tempo o decodificador da mensagem. 
2. Indivíduo/objeto interativo/objeto interativo/indivíduo - o indivíduo envia uma mensagem e o objeto interativo codifica em sinais. Outro objeto interativo decodifica os sinais em mensagem novamente.

3. Indivíduo/objeto interativo/grupo de indivíduos - um indivíduo envia uma mensagem a ser recebida por um grupo de indivíduos, sendo que o objeto interativo é como no primeiro caso, tanto codificador como decodificador. A princípio pode parecer que se trata do mesmo procedimentos do item 1, contudo, justifica-se a separação entre esquemas em que existem dois indivíduos, dispostos como fonte e receptor, daqueles nos quais existe um grupo de indivíduos como emissor ou receptor. Mediada por um objeto interativo, a mensagem pode assumir diversas formas, que podem ser diferentes inclusive em função do número de pessoas envolvidas no processo de comunicação. Isso significa que a mensagem a ser enviada ou recebida quando há apenas um indivíduo nos extremos do esquema é diferente quando se tem um grupo de pessoas. Tanto a mensagem recebida quanto a enviada pode ter conteúdos diferenciados se em um dos extremos houver, como condicionante, a presença de um grupo.

4. Grupo de indivíduos/objeto interativo/grupo de indivíduos - da mesma forma que a existência de um grupo de indivíduos em um extremo do processo significa alteração de conteúdo para as mensagens, a existência de grupos de indivíduos nos dois extremos também implica em outros atributos para as mensagens enviadas e recebidas. Assinalase esse esquema como diferenciado em relação ao anterior, pois os dois esquemas podem estar presentes no mesmo sistema de comunicação e, se assim for considerado pelo designer, as mensagens podem ser produzidas pelo condicionante imposto pelo número de pessoas em ambos os extremos. 
5. Grupo de indivíduos/objeto interativo/objeto interativo/grupo de indivíduos - a mensagem enviada por um grupo de indivíduos é transformada em sinal de codificador/objeto interativo, transmitida por meio de um canal e recebida por outro objeto interativo/decodificador.

6. Indivíduo/objeto interativo/equipamento eletrônico existente/indivíduo - além do objeto interativo como codificador e/ou decodificador de mensagens, insere-se algum aparelho eletrônico existente como telefones celulares, computadores, PDA (acrônimo em inglês para Personal Digital Assistants ou Assistente Pessoal Digital), GPS (acrônimo em inglês para Global Positioning System ou Sistema de Posicionamento Global), entre outros dispositivos eletrônicos disponíveis.

7. Grupo de indivíduos/objeto interativo/equipamento eletrônico existente/indivíduo - nesse caso entende-se que a mensagem produzida por um grupo de indivíduos somente pode ser codificada e/ou decodificada pelo objeto interativo, pois este equipamento estaria preparado para diferenciar as mensagens produzidas por um indivíduo daquelas produzidas por um grupo. Os equipamentos existentes geralmente relacionam-se com o indivíduo que os possuem. Ou seja, geralmente eles não são dotados da capacidade de diferenciar se existe uma pessoa ou várias em contato com ele. Pode-se falar que vários indivíduos providos de seus respectivos aparelhos estejam enviando ou recebendo mensagens emitidas por um grupo de indivíduo por meio do objeto interativo. No entanto, mesmo que o alcance da mensagem venha a incluir várias pessoas, elas não se constituem como um grupo cujas ações apenas enquanto grupo uno irão produzir ou receber determinada mensagem.

8. Indivíduo/equipamento eletrônico existente/indivíduo - neste caso não há objeto interativo, mas é uma possibilidade que pode ser explorada 
pelo designer associando-a ou não a outros esquemas. Refere-se a qualquer equipamento eletrônico que transmita e receba sinais e os transforme em mensagens.

9. Indivíduo/equipamento eletrônico existente/equipamento eletrônico existente/indivíduo - por este esquema, pode-se ter como exemplo a comunicação nas quais as mensagens são codificadas e decodificadas por computadores, telefones celulares, entre outros equipamentos disponíveis.

Os esquemas acima apresentados e descritos foram algumas possibilidades elencadas nesta pesquisa de Mestrado. Assim como na questão espacial e temporal, os esquemas não são excludentes. Pode-se associar vários deles sob diversos aspectos, sendo possível ainda estabelecer outros esquemas não definidos acima. Isso dependerá da habilidade do designer de explorar novas possibilidades e também do desenvolvimento tecnológico que vai introduzindo novos componentes e circuitos eletrônicos, fornecendo assim insumos para a exploração de novas formas de comunicação.

\subsection{LEITURA PELOS OBJETOS}

Este item tem como objetivo fazer uma leitura crítica dos objetos coletados por pesquisadores do Nomads.usp e que compõem o banco de dados do Núcleo acerca de objetos interativos produzidos por centros de pesquisa, empresas, artistas, designers, arquitetos entre outros profissionais que contemplem as tecnologias digitais e eletrônicas. Essa leitura possui como categorias de análise os tópicos discutidos até o momento neste capítulo. Procura-se compreender de que forma os designers contemplaram questões referentes às interações, percepção sensorial, memória, narratividade, processo de significação e comunicação em suas proposições. Assim, pretende-se entender as intenções do designer 
manifestadas nos objeto e como isso se reflete sobre o processo de design. Cabe enfatizar que os objetos selecionados para esta leitura não foram desenvolvidos pelos princípios e conceitos do design para experiência, mas as formas como os designers trabalharam determinadas questões poderiam ser consideradas dentro do contexto do design para experiência.

As propostas foram analisadas pelas chaves de leitura provenientes da discussão acima apresentada, porém elas não estão amarradas a essas categorias. Por vezes algumas proposições serão analisadas dentro de determinada categoria, mas a leitura se estende por outras. Por exemplo, se uma proposta está sendo analisada pela percepção sensorial, tal condição não se constitui como um fator excludente das outras categorias. A leitura também não tem como intuito ser quantitativa procurando manifestações estatísticas sobre cada categoria de análise.

Algumas propostas analisadas não foram de fato prototipadas. Muitas se referem a projetos desenvolvidos por alunos de escolas que trabalham com a relação entre homem e tecnologia da informação e comunicação por meio do design. Algumas utilizam como base os métodos do interaction design, outras envolvem explorações mais críticas sobre o tema. Seja qual for a abordagem, ela não invalida a análise que se pretende fazer sobre tais proposições.

\subsubsection{Pelas interações}

Ao tomar as interações como categoria de análise para a investigação do processo de design pelos objetos, enfatiza-se as condições para um sistema ser considerado como tal. A averiguação parte, portanto, das considerações acerca da contextualização ou do cenário construído, intencionalmente ou não, pelo designer para o desenvolvimento do objeto, dos elementos 
envolvidos no sistema e de suas propriedades - que são determinantes para que as interações ocorram.

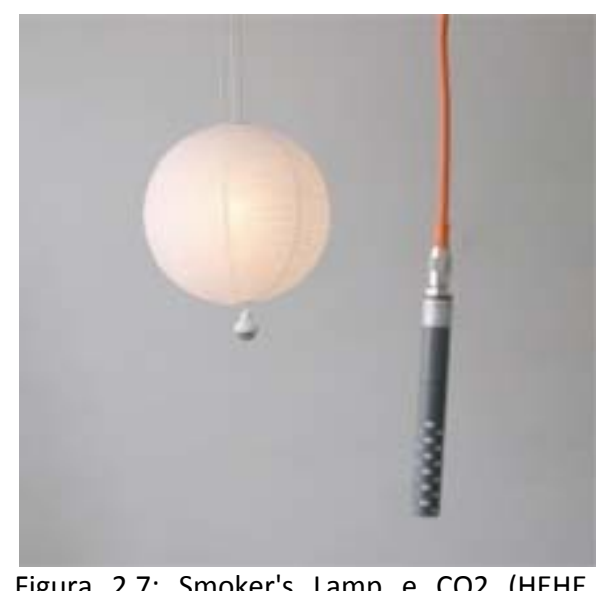

Figura 2.7: Smoker's Lamp e CO2 (HEHE, 2005).

proposições desse projeto, que compreende instalações artísticas, fotografias, performances e outras formas de expressão estética, está o desenvolvimento de uma proposta chamada Smoker's Lamp \& CO2 Room que visa promover uma reflexão sobre a temática por meio das relações entre pessoas e objetos.

A proposta do Smoker's Lamp envolve um objeto com detectores sensíveis à nicotina instalado em uma área para pessoas não fumantes de determinado espaço. O objeto, ao captar determinado nível da substância no ar, altera seus padrões luminosos. Essa capacidade dada ao objeto instiga as pessoas a exalarem a fumaça de seus cigarros mesmo estando em um local onde isso não é permitido, infringindo, portanto, as regras de conduta estabelecidas. Sob uma ótica sistêmica pode-se colocar como cenário, ou condição de encontro, a sala onde o objeto está instalado e a situação gerada por esse objeto na sala. Apesar de ser um local onde o ato de fumar está proibido, as pessoas se sentem instigadas pelo objeto a transgredir as regras. 
A interação entre o objeto e as pessoas também só foi possível pela exploração de certas propriedades tanto do objeto quanto das pessoas. Pessoas não-fumantes não teriam o interesse em exalar a fumaça de um cigarro apenas para permitir que o objeto altere seu padrão. A característica fumante do indivíduo é essencial para que a interação se constitua como tal. Não é possível responder se o sistema formado pelos elementos indivíduos fumantes, indivíduos não-fumantes e objeto será um sistema organizado ou não, exceto por uma análise dos eventos ocorridos. Por exemplo, os não-fumantes poderiam se articular para pedir a transferência do objeto para outro local. Poderiam os fumantes se sentirem, após a excitação da transgressão, envergonhados e nunca mais passarem pela sala novamente, poderiam eles se organizarem para levar o objeto para ouro lugar, ou excluir de vez os não-fumantes da sala e instituírem uma nova qualidade para a sala, a sala dos fumantes.

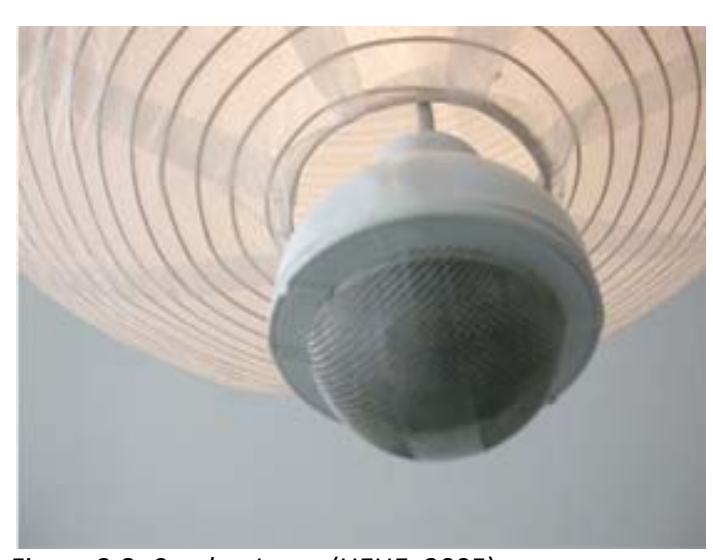

Figura 2.8: Smoker Lamp (HEHE, 2005).
Enfim, como o sistema se reorganizaria para a emergência de novas qualidades é uma questão que permanece, neste trabalho, no campo das suposições. Não há referências sobre uma possível abordagem sistêmica para o Smoker's Lamp ou sobre como foi o processo de desenvolvimento da proposta exceto pela consideração inicial sobre a emissão de gases na atmosfera, mas é possível pensar em um processo de design baseado nos conceitos de sistemas. 


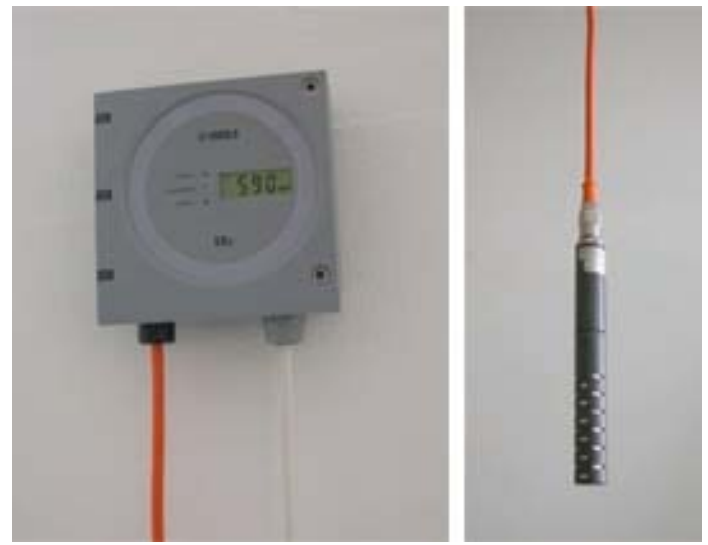

Figura 2.9: CO2 da dupla HEHE (HEHE, 2005).

Ainda dentro da mesma proposta, o CO2 talvez não possa ser considerado pela ótica sistêmica. Ou as propriedades de seus elementos forem assim exploradas, elas não são fortes o suficiente para que as interações se constituam. A principal propriedade do objeto envolvido é a de detectar o nível de gás carbônico no ambiente. Em relação às propriedades do indivíduo, foi explorada unicamente a sua presença no ambiente. Um visor mostra a alteração dos níveis de concentração de gás carbônico no ambiente conforme o número de pessoas vai aumentando. Com isso, os designers propõem uma reflexão sobre o corpo, o quanto se pode poluir o ar apenas existindo. No entanto, apesar de fornecer condições de encontro, as propriedades dos elementos parecem não ser muito exploradas pelos designers a ponto de permitir interações fortes entre indivíduos e objeto. Com isso, dificilmente poderá surgir uma forma nova de organização do sistema. Na verdade, as relações entre o objeto e o indivíduo estão mais para ação e reação do que para interações num sistema propriamente dito.

Pode-se também fazer uma leitura dessas propostas pela categoria de análise referente à percepção sensorial e à comunicação. Da percepção, explora-se mais a visão, embora para os fumantes o paladar e o olfato também estejam envolvidos. Da comunicação, trabalha-se com os esquemas de comunicação entre o indivíduo e/ou indivíduos mediada por 
um objeto. O interessante nessa proposta é a aliança entre as duas instâncias. A mensagem transmitida, principalmente no caso do $\mathrm{CO} 2$, envolve uma informação que não é percebida pelas pessoas, a quantidade de gás carbônico que o próprio corpo humano libera no ambiente. Transformada em mensagem e percebida pelo indivíduo por meio de uma linguagem visual, pode-se ativar um processo de reflexão, proposital, mas sem o controle do designer, pois o acesso à informação pode não provocar nenhuma instigação no indivíduo se não existir o processo cognitivo da atenção, que conduziria o envolvimento do indivíduo com a questão.

\subsubsection{Pela percepção sensorial}

Uma pessoa entra em um bar para tomar algo, mas não há ninguém preparando bebidas. Quem - ou o que - faz isso é o BrainBar, um bar mecânico. Contudo não se trata de uma máquina de bebidas como aquelas nas quais as

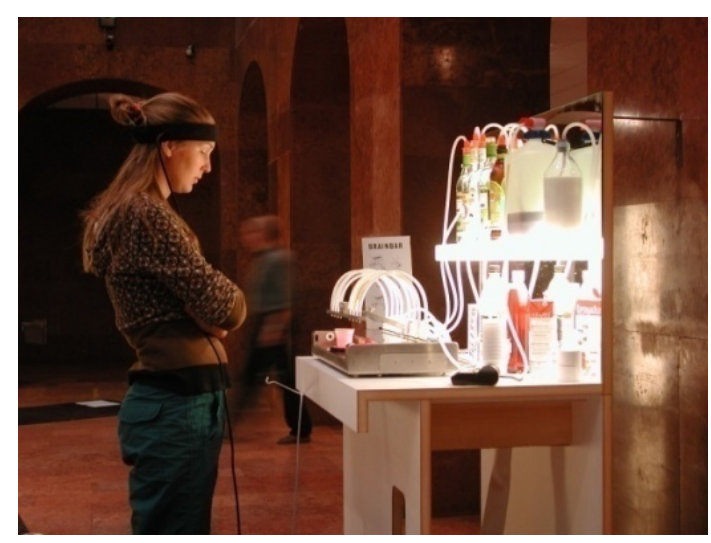

Figura 2.10: O BrainBar, desenvolvido no Smart Studio do Interactive Studio em 2001 (SMART STUDIO, 2001) pessoas depositam moedas e escolhem entre várias possibilidades o que irá tomar. O BrainBar prepara a bebida de acordo com as ondas cerebrais que a pessoa emite. Por meio da leitura do comprimento das ondas da frequência cerebral o equipamento prepara a bebida que considera adequado para a pessoa no momento em que foi feita a medição. O BrainBar foi desenvolvido no extinto Smart Studio do Interactive Studio por uma equipe formada por vários pesquisadores com formação diversas, como artes e engenharia. 


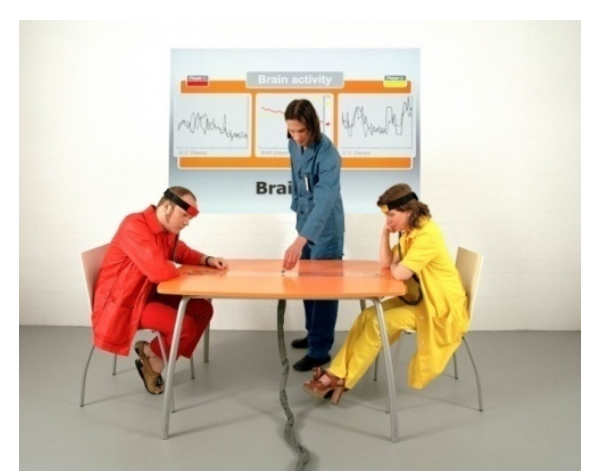

Figura 2.11: BrainBall, desenvolvido pelo Smart Studio do Interactive Institute entre 1999 e 2000 (SMART STUDIO, 2000).
A leitura do Brainbar pelas lentes da percepção sensorial indica claramente a exploração da relação entre indivíduo e objeto pelo paladar, embora outros sentidos ainda estejam presentes como o olfato e a visão. Porém, a equipe de design que desenvolveu a proposta toma a relação entre indivíduo e

objeto pelo paladar como pretexto para um questionamento maior: até que ponto uma pessoa permite que uma máquina interfira nas suas vontades, neste caso, na vontade de beber algo? Assim, parece que a exploração dos sabores não foi a motivação inicial da proposta e sim uma possibilidade de explorar mais a tecnologia que, inclusive, deriva de outra proposição do mesmo instituto, o BrainBall. Essa proposta utiliza o sistema de medição do comprimento das ondas cerebrais para um jogo. Em uma mesa, há uma bola que se movimenta conforme as ondas cerebrais captadas pelos participantes do jogo. Porém, ganha aquele que estiver mais relaxado no momento do jogo, distorcendo a própria idéia de estar em uma condição de jogo que envolve ansiedade e nervosismo.

De forma menos intrusiva para o indivíduo que o BrainBar, a proposta do Tè-per-te de Patray Lui desenvolvida no IVREA - Interaction Design Institute em 2005, explora a percepção sensorial do paladar pela degustação de chá dentro do contexto da cultural oriental envolvida em sua apreciação. Suponha-se que uma pessoa deseje degustar a infusão de determinadas ervas. Ela recorre a um objeto que poderá sugerir qual erva utilizar. Ao se aproximar do objeto, ele captará a mensagem emitida pelo próprio corpo da pessoa referente ao peso e à altura. Por sensores térmicos, o objeto processa a mensagem emitida pelo corpo em relação a sua temperatura. Além das informações contidas em cada mensagem enviada pelo corpo humano, o objeto precisa de informações relacionadas ao estado 
emocional e por meio de certas perguntas a pessoa responde sobre o que ela está sentindo naquele momento. Pelo processamento dessas informações o objeto sugere uma combinação de ervas para infusão. No próprio objeto a pessoa visualiza e recolhe as ervas sugeridas, se assim ela decidir.

Percebe-se que a questão da situação promovida pela degustação do chá direcionou o trabalho da designer no que se refere ao desenvolvimento das relações entre um indivíduo e o objeto interativo. Há um contexto envolvendo as ações da pessoa para com o objeto, que é a apreciação

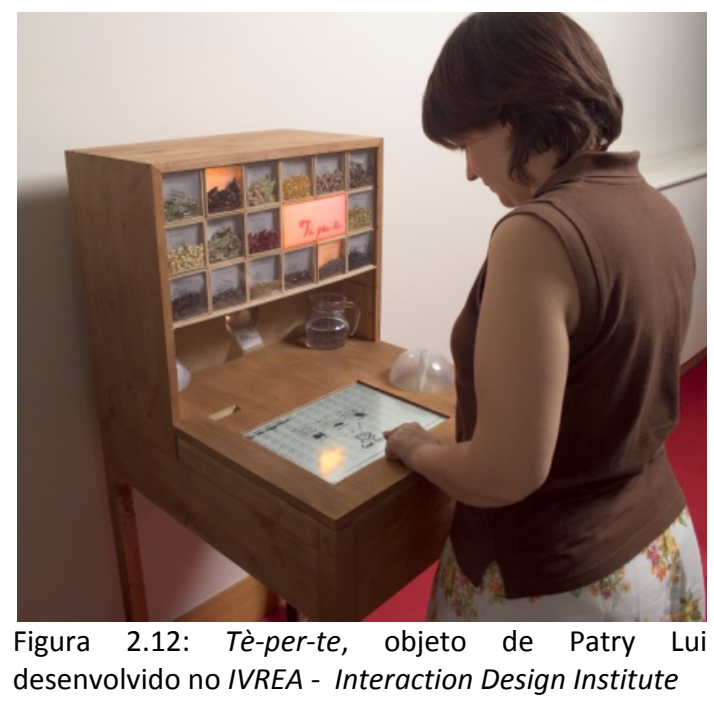
do ato de tomar chá. Partindo das ações e motivos pelas quais uma pessoa pode desejar ingerir uma infusão, por suas propriedades terapêuticas, por exemplo, a designer explora que tipos de mensagens uma pessoa pode enviar para o objeto e como ele as processará para enviar outra mensagem para a pessoa - neste caso, quais ervas selecionar. Entretanto o objeto é mais reativo do que interativo. Uma vez que a pessoa entre em contato com o objeto e este responda conforme sua programação, a relação entre os dois se esgota. Além disso, não há elementos de novidade que possam instigar o indivíduo a retornar ao objeto para degustar uma outra infusão.

Outro projeto também desenvolvido por alunos do IVREA - Interaction Design Institute aborda a audição como o sentido perceptivo a ser explorado. Na proposta intitulada Speak Out dos designers Tristam Sparks, Andréa Bhelaru e Ana Camila Amorim, os sons de uma habitação são 
tomados como principio norteador. Procura-se explorar os sons das atividades do cotidiano das pessoas no interior do espaço da habitação. A proposta consiste em transformar os sons em um sinal passível de ser transmitido por determinado canal e novamente transformado em mensagem por outro objeto decodificador que, por meio de auto-falantes, reproduz os sons captados. Cada habitação possui um objeto com a capacidade de codificação e de decodificação dos sinais.

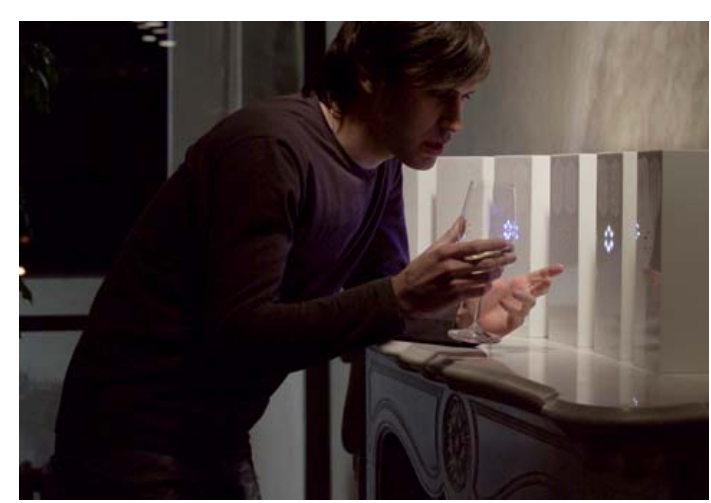

Figura 2.13: Speak out. Tristam Sparks, Andréa Bhelaru e Ana Camila Amorim (INTERACTION DESIGN INSTITUTE IVREA , 2005a).
Desde que um indivíduo seja capaz de focar sua atenção sobre determinado som proveniente de outra habitação, ele pode alterar seu comportamento, desejando uma conversa com a pessoa da outra habitação, estreitando os laços afetivos entre elas. No entanto, apesar de declaradamente a questão sonora ter sido o sentido perceptivo base para o desenvolvimento do projeto, parece que os designers tocaram na temática de forma superficial. Se considerado o processo perceptivo dos seres humanos, deve-se atentar para uma característica vinculada aos sentidos humanos: o processo cognitivo da atenção. Se não houver uma informação relevante que faça com que o indivíduo foque sua atenção, ela será uma informação não processada. Além disso, o sistema perceptivo tem a habilidade de se entediar. Se não houver estímulos novos com frequência, o sistema também passa a ignorar os dados recebidos por determinado sensor humano. No caso dessa proposta, essa situação parece quase inevitável visto que os sons das atividades da habitação podem soar como sons de fundo, que geralmente as pessoas ignoram. Talvez uma possibilidade para estimular esse sentido seria a amplificação de determinadas freqüências, para de fato provocar 
nos indivíduos um direcionamento de sua atenção para o que está ocorrendo na outra habitação.

\subsubsection{Pela construção e resgate das memórias}

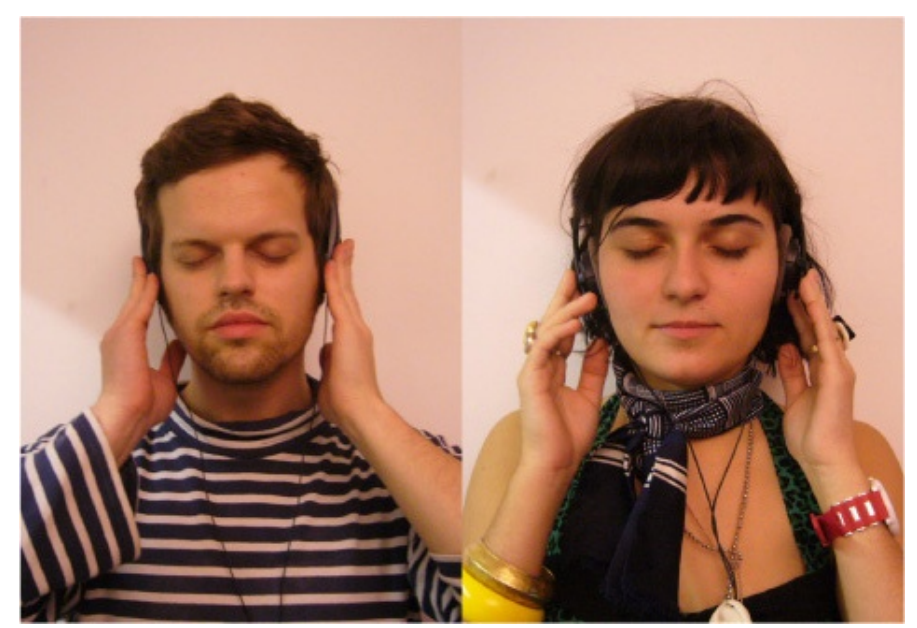

Figura 2.14: Vector Memory desenvolvido no Design Interactions Department do Royal College of Arts de Londres pelo arquiteto e designer Nitipak Samsen. (DESIGN INTERACTION AT THE RCA, 2009).

Suponha que um indivíduo ouça uma música e goste dela. Com o Vector Memory ele pode gravar a música que the tenha despertado algum interesse. Porém se o indivíduo não se lembrar de ouvi-la com certa frequência, a musica gravada será deletada da memória do objeto. O Vector Memory foi desenvolvido no Departamento de Design Interaction do Royal College of Arts de Londres por Nitipak Samsen e trabalha aspectos relacionados com a memória. O objeto reproduz a forma como os seres humanos conseguem gravar determinada informação na memória. Pela repetição, uma informação pode ser armazenada na memória de longo prazo. A informação que o objeto capta é armazenada em sua memória, mas é preciso que o indivíduo mantenha um padrão de repetição para que ela não seja apagada.

Apesar do designer recorrer aos modelos da psicologia cognitiva sobre memória em relação a apenas uma propriedade do objeto interativo, ele 
acaba estimulando o processo cognitivo da memória das próprias pessoas, afinal ao acionar a informação repetidas vezes no objeto os indivíduos também estão ativando seus próprios processos de memorização e recuperando memórias, pois as músicas podem representar o processo de significação que remeterá o indivíduo à situação em que ela foi gravada. Pelas informações coletadas sobre o objeto não se pode saber ao certo se essa foi a intenção do designer. Contudo, como o intuito é procurar dados que podem ter sido relevantes para o designer, a partir de suas manifestações nos objetos, entende-se, que a memória foi o elemento central do desenvolvimento dessa proposta - não apenas do objeto, mas também de sua relação com o indivíduo. O objeto Vector Memory também permite que o indivíduo envie a música por ele armazenada para outras pessoas por meio do Bluetooth, sistema de transmissão de dados via rádio para curtas distâncias. Com isso pode-se explorar também a comunicação entre pessoas por meio de objetos interativos.

\subsubsection{Pela comunicação}

O projeto chamado Remote Home, desenvolvido por uma equipe de design do Smart Studio do Interactive Institute, toma como principio a exploração da comunicação à distância pelos objetos que compõem o ambiente doméstico. Trabalha-se com as formas de comunicação entre duas pessoas que possuem laços familiares e/ou afetivos, mas que estão separadas fisicamente. O projeto foi coordenado pelo arquiteto Tobi Schneidler e contou com a colaboração de profissionais de diversas áreas como engenheiros, programadores entre outros. A equipe desenvolveu duas versões, expostas em museus, que contemplavam o mesmo questionamento por objetos diferentes.

O projeto parte da suposição de que um casal more em cidades diferentes. Um em Londres e outro em Berlin. Eles poderiam se comunicar de várias 
maneiras, por telefone, emails, comunicadores instantâneos entre outros meios. No entanto, as mensagens enviadas ficariamm restritas à oralidade $\mathrm{e}$ à escrita, sendo que os processos de comunicação envolvem gestos, postura do corpo, forma de se vestir, comportamentos entre outras formas de comunicação. Cherry (1971) assim assinala a abrangência da comunicação humana:

\begin{abstract}
A fala e a escrita não são, de modo algum, nossos únicos sistemas de comunicação. O intercâmbio social é grandemente reforçado por hábitos de gesticulação pequenos movimentos das mãos e da face. Com acenos de cabeça, sorrisos, carrancas, apertos de mão, beijos, agitar de punhos e outros gestos, podemos comunicar compreensão mais sutil. [...] Temos convenções de trajes. De tráfego, formalidades sociais e boas maneiras; temos regras de filiação e função em negócios, instituições e famílias (CHERRY, 1971, p. 24).
\end{abstract}

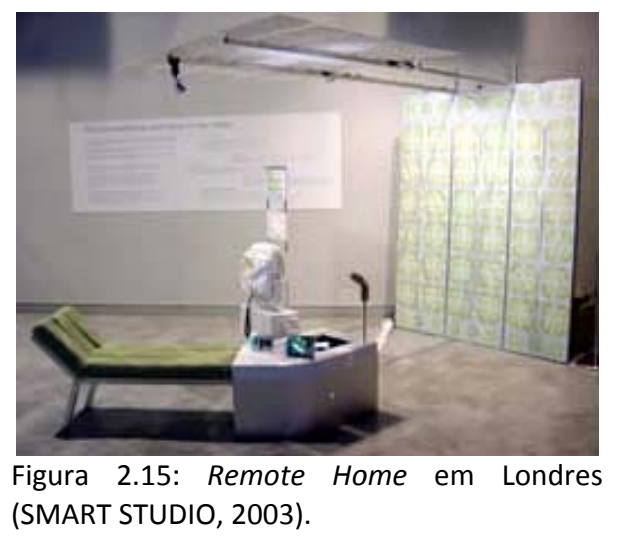

O Remote Home procura explorar, portanto, outras formas de comunicação, focando principalmente a linguagem visual e a cinética dos objetos e o esquema de comunicação indivíduo/objeto interativo/objeto interativo/ indivíduo, associados à comunicação síncrona, assíncrona e remota. As mensagens que um indivíduo envia para o outro podem ser provenientes apenas de sua presença perante um dos objetos do ambiente, que irá codificar essa informação transmitindo sinais por um canal de comunicação - no caso dessa proposta, uma rede de transmissão de dados 
como a internet. Na outra cidade, outro objeto decodifica os sinais novamente numa mensagem, que pode ser expressa tanto por padrões luminosos como por movimentos dos objetos desse ambiente.
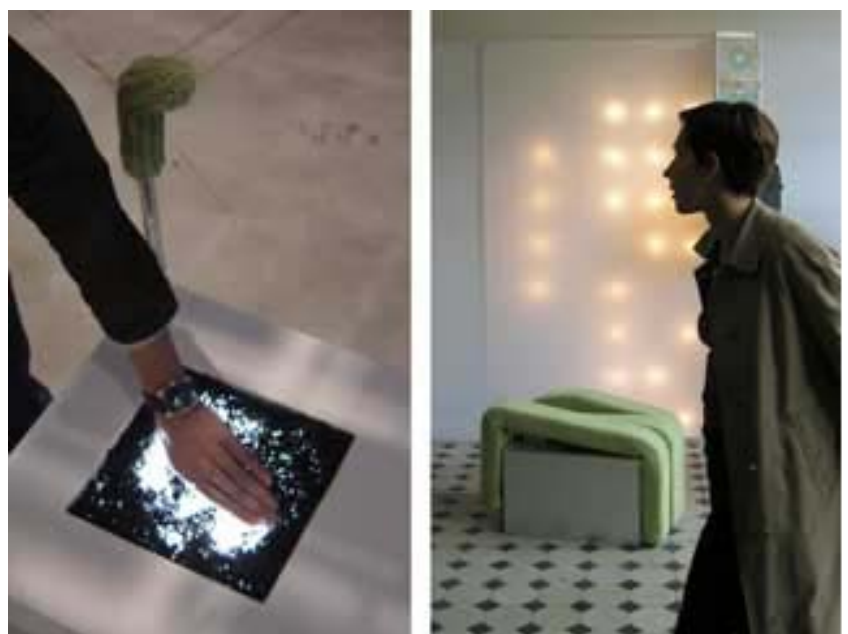

Figura 2.17: Um dos objetos do Remote Home transforma a mensagem deixada em sua superfície em sinal e é transmitida para o outro ponto por meio de padrões luminosos em uma superfície e pelo movimento de outro objeto (SMART STUDIO 2003).

O intuito da equipe de design foi o de trabalhar com questões referentes à comunicação, sendo que a forma como as mensagens são enviadas foram determinadas a partir de explorações sobre como as pessoas poderiam se comunicar. No entanto, explorar a comunicação em várias instâncias pode promover confusão para o indivíduo em relação a qual ação sua está sendo enviada pelo sistema de comunicação. Muitas podem ser as entradas e nem sempre se recebe um retorno do que se está de fato enviando para o outro extremo do esquema de comunicação.

Além disso, percebe-se que os critérios para o desenvolvimento da instalação estão pautados mais pela exploração tecnológica do que, efetivamente, por processos de comunicação. A mesma mensagem poderia ser transmitida de forma simplificada, como por exemplo, enviando apenas um sinal luminoso. Explorar a cinética dos objetos, entretanto, não acrescenta informação relevante para as pessoas, mesmo sob a perspectiva 
da percepção, pois após certo tempo, o movimento deixaria de ser uma novidade.

O Tableportation é um projeto desenvolvido por Giorgio Olivero e Peggy Thoeny no IVREA - Interaction Design Institute. Trata-se de uma exploração da comunicação entre as pessoas em um ambiente de uso coletivo, como um café. Pessoas sentadas em suas mesas podem criar mensagens por meio de um sistema luminoso instalado na superfície das mesas. A mensagem luminosa, bem como a própria presença das pessoas se tornam mensagens quando é formada uma imagem captada por uma filmadora fixada em cima das mesas. Elas são codificadas e enviadas para um decodificador, que transforma o sinal em mensagem visual novamente e transmitida de volta para as pessoas por meio de uma grande tela de projeção. No entanto, as imagens enviadas por cada mesa são decodificadas e visualizadas por um único aparelho, possivelmente um computador e algum software capaz de agrupar todas as mensagens visuais em uma única interface gráfica.

Nesse caso, pode-se considerar os seguintes esquemas de comunicação: indivíduo/objeto interativo/equipamento existente/indivíduo, sendo que a mensagem é emitida e recebida por um individuo que, inclusive, pode ser a mesma pessoa; indivíduo/objeto interativo/equipamento existente/grupo de indivíduos, pois a mensagem transmitida pode provocar outras ações das pessoas enquanto grupo; pode ser também um esquema grupo de indivíduos/objeto interativo/equipamento existente/ grupo de indivíduos, por também permitir que as mensagens possam ser enviadas por um grupo de indivíduos - considerando que há diferenças entre o que é enviado por uma pessoa e o que é enviado pela ação de duas ou mais pessoas. 


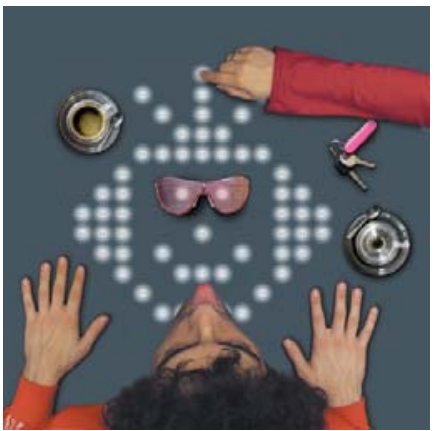

Figura 2.18: Tableportation. Imagem captada das mesas (INTERACTION DESIGN INSTITUTE IVREA, 2004).

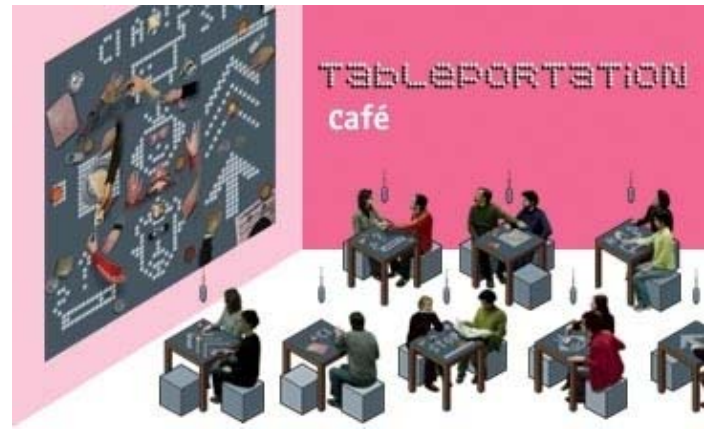

Figura 2.19: Tableportation. Sobreposições das imagens das mesas na interface gráfica (INTERACTION DESIGN INSTITUTE IVREA, 2004).

Provavelmente o designer não pensou em esquemas de comunicação como os apresentados nesse trabalho. Mas parece estar ciente das possibilidades de comunicação entre as pessoas e ter tomado esse princípio como o foco para o desenvolvimento da proposta. Do ponto de vista dos sistemas, criase um contexto, ou seja, uma condição de encontro dos elementos representado pelo café. A característica enfatizada pelo elemento indivíduo é sua capacidade de comunicação sob várias linguagens. Os outros elementos do sistema como o objeto interativo e o equipamento de decodificação das mensagens são elaborados para captar, processar e transmitir segundo a linguagem enfatizada pelo designer, a linguagem visual. Com essa leitura, pode-se supor que o designer tenha partido do alto potencial de comunicação entre as pessoas e como o comportamento delas é também alterado em função dessa capacidade. 

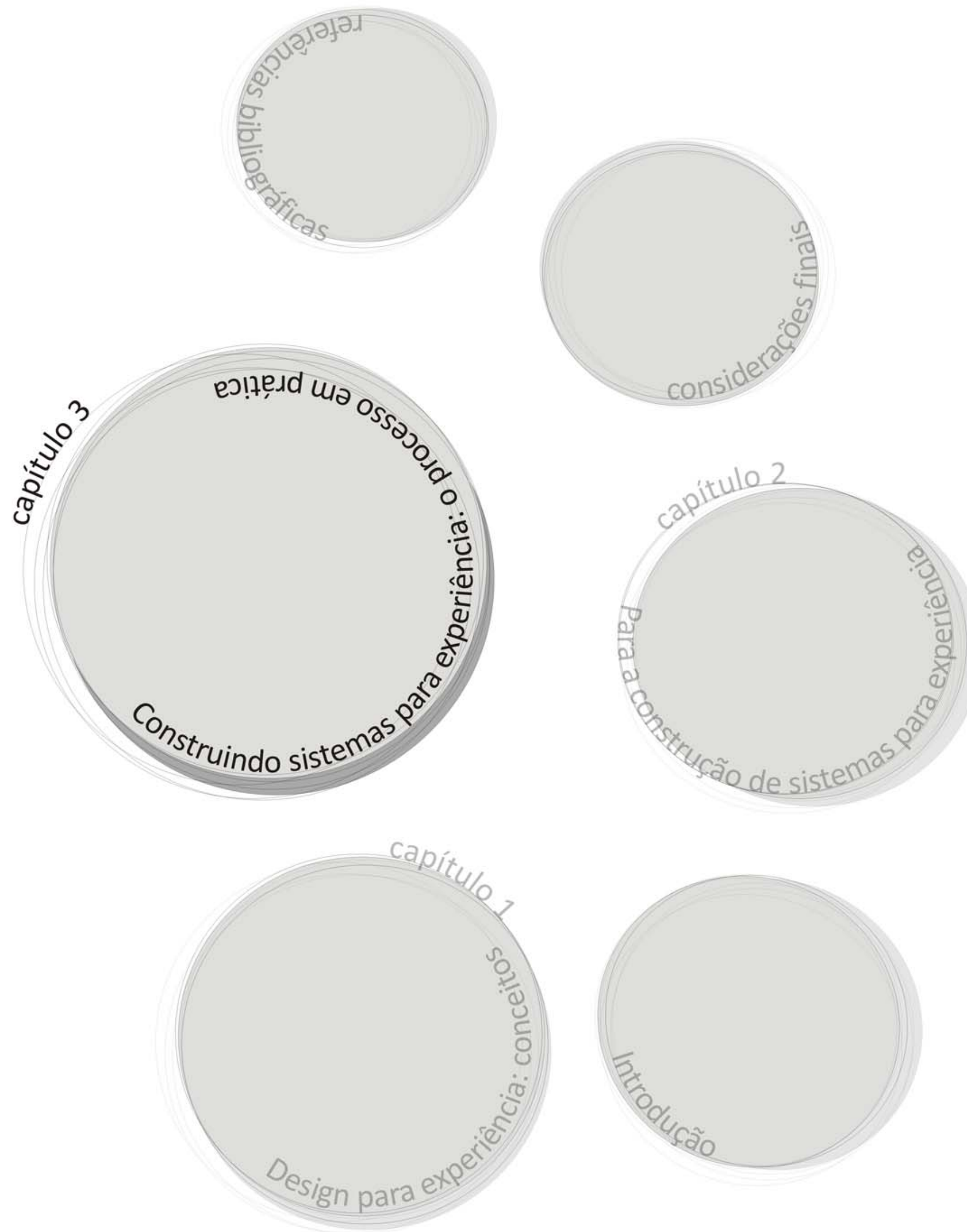

Este trabalho recorre à conciliação entre investigação teórica e atividade prática como procedimento metodológico. Procura-se quebrar os limites impostos pela dualidade entre teoria e prática para torná-las uma entidade una. $O$ intuito é obter uma visão mais abrangente e completa do objeto de pesquisa em questão: o processo de design, e mais especificamente, o processo envolvido no design para experiência.

Neste capítulo, pretende-se fazer uma leitura crítica das ações dos designers em experimentações do Nomads.usp. As propriedades da relação indivíduo e objeto interativo foram utilizadas pelos pesquisadores do Núcleo com o intuito de entender como podem ser os processo de design envolvidos quando se trabalha com o design para experiência. Procura-se extrair também outros dados relevantes sobre o processo de design, primando dessa forma, por uma visão mais ampliada do desenvolvimento de sistemas para a emergência de experiências.

O estudo do processo se faz relevante, dada as peculiaridades que o design para experiência faz insurgir. Nem a forma, nem a estética, nem a eficiência são as metas a serem alcançadas com o desenvolvimento de produtos. Prima-se antes de tudo por experiências. Se os objetivos e os produtos do design para experiência são diferenciados, o processo de design também se apresenta de forma distinta.

Tal consideração foi ressaltada pelo procedimento metodológico adotado que envolve teoria e prática. Não apenas esta pesquisa recorre a tal aproximação entre as duas entidades. Pesquisas realizadas no Nomads.usp a tomam como premissa. Foi através dessas explorações práticas que se reforçou a necessidade de um estudo mais aprofundado sobre processos de design envolvidos no design para experiência. 
O projeto Pacto Digital ${ }^{88}$ foi uma das primeiras tentativas do Núcleo de desenvolver um projeto segundo os princípios norteadores do design para experiência. Tratava-se do projeto de um edifício destinado à comercialização de tecnologias de automação residencial, incluindo espaços para treinamentos e para a exposição de produtos. Trabalhando diversas escalas de intervenção, do objeto como mobiliário ao urbano considerando as relações do edifício com seu entorno -, em todas as instâncias os pesquisadores adotaram o design para experiência como abordagem. No entanto, apesar do entendimento da temática, pairavam incertezas sobre o processo. Apesar de já se ter produzido várias pesquisas que se dedicavam ao estudo do processo de design, os resultados desses estudos ainda eram parciais.

No processo de design para o Pacto Digital, a abordagem da relação indivíduo e objeto não partiu da exploração das propriedades referentes a ela. Os designers voltaram-se para o desenho dos ambientes e dos objetos interativos em si, sem se preocuparem com o indivíduo no espaço em contato com os objetos. Essa forma de considerar as relações entre esses dois elementos acabou condicionando e restringindo as ações do designer. Ao invés das propriedades da relação entre os elementos, designers ocuparam-se com aspectos formais, funcionais e estéticos do edifício, ou seja, as propriedades do objeto que para o design para experiência não são as mais relevantes, já que o produto esperado é a experiência.

\footnotetext{
${ }^{88} \mathrm{O}$ projeto foi realizado em parceria com uma empresa de automação residencial. Nessa parceria, o objetivo era desenvolver um projeto para a sede da empresa que contemplasse espaços para a venda, para treinamento técnico e para exposição dos produtos. Para todas essas espacialidades exigidas pelo programa, o Nomads.usp pôde trabalhar segundo os conceitos do design para experiência, principalmente para o espaço de exposição que na verdade era uma habitação onde pessoas poderiam se hospedar por um determinado tempo. Assim, o Núcleo encontrou a possibilidade de desenvolver um projeto de habitação pelos princípios norteadores do design para a experiência.
} 


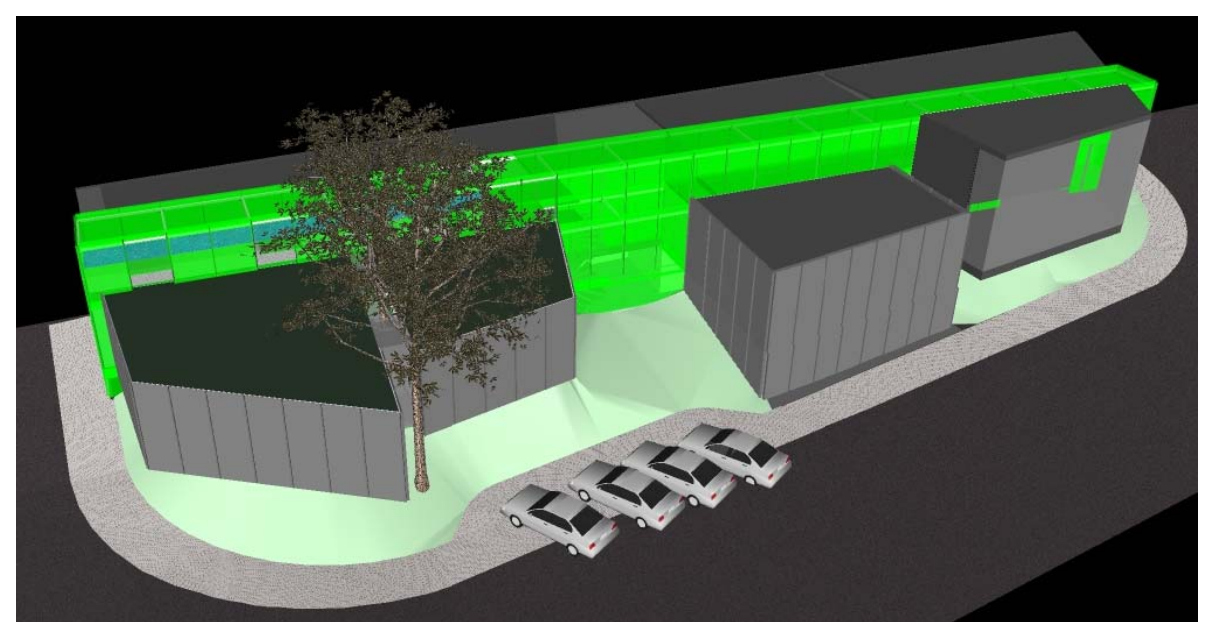

Figura 3.1: Modelagem em 3D do edifício projetado segundo os conceitos do design para experiência. (NOMADS.USP, 2008b)

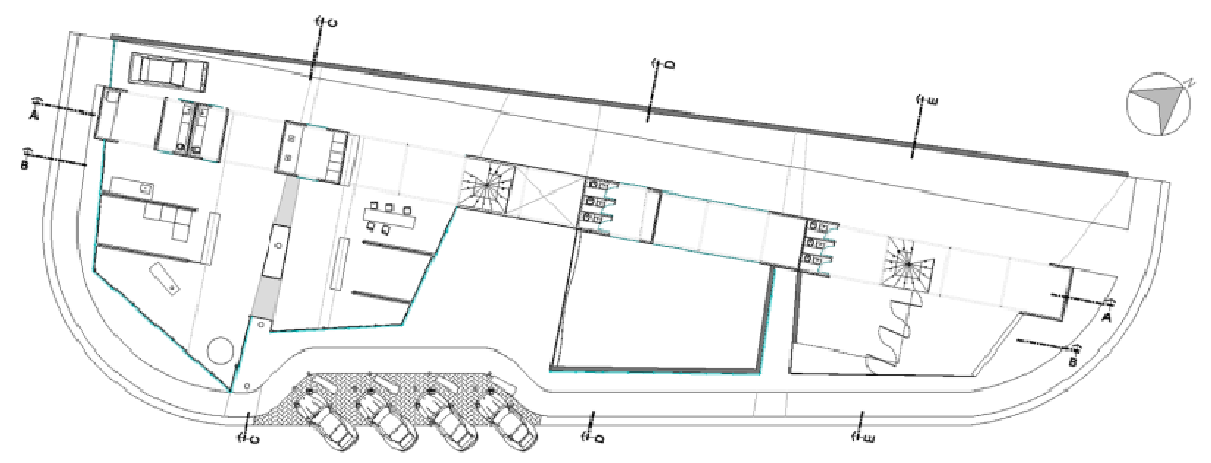

Figura 3.2: Planta do edifício nível 0.00m (NOMADS.USP, 2008c).

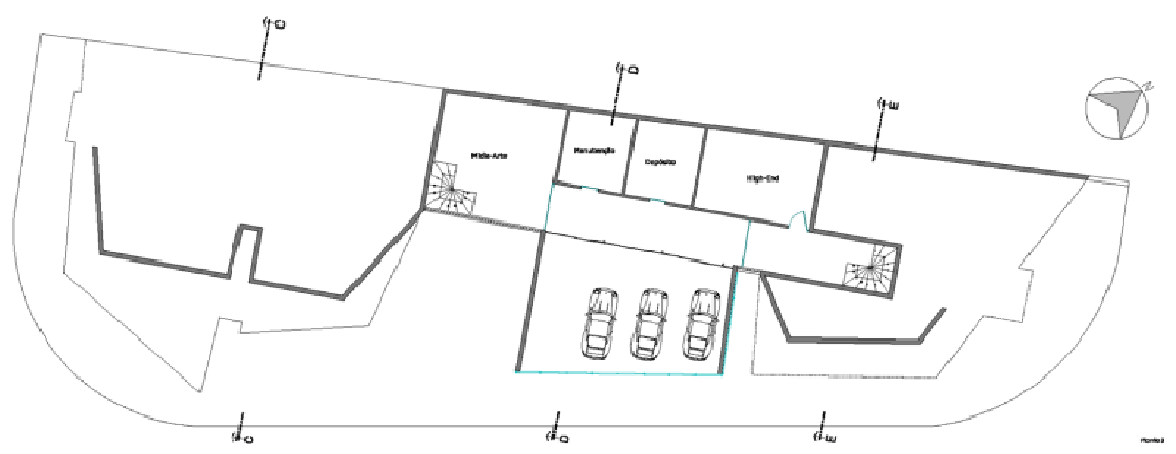

Figura 3.3: Planta do edifício nível - 2.88m (NOMADS.USP, 2008c). 


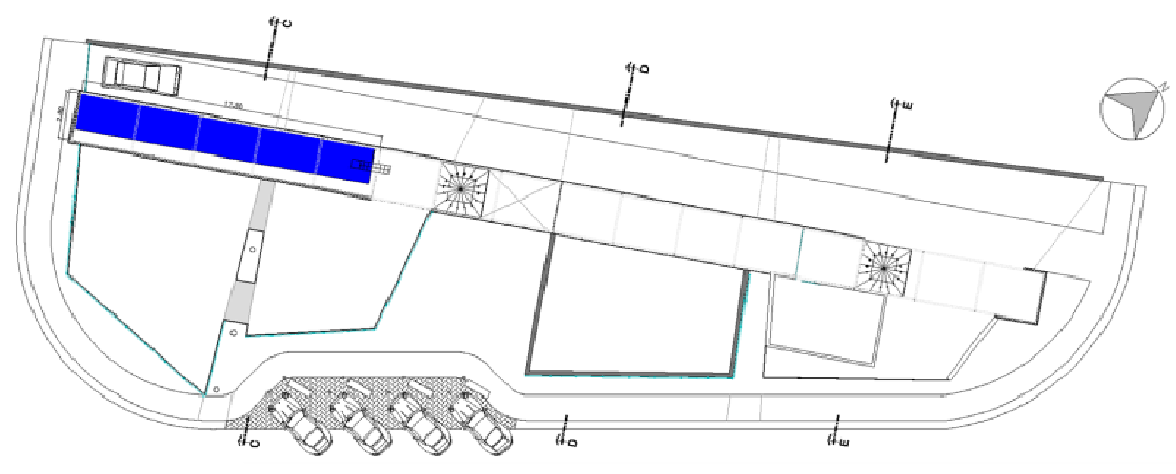

Figura 3.4: Planta do edifício nível + 3.88m (NOMADS.USP, 2008c).

O edifício foi dividido em seis espacialidades: (1) experiência, área da habitação; (2) formação, referente ao treinamento técnico de profissionais da área de automação; (3) jardim; (4) travessia, área que permite o cruzamento pelo edifício sem necessariamente entrar nele; (5) interface, espaço que articula circulações e está entre a travessia e os espaços da experiência e formação; (6) geral, referente aos objetos interativos presentes no interior e dos sistemas de segurança.

O direcionamento do foco para o objeto e para o espaço condicionou até mesmo as formas de representação da proposta, como pode ser visto nas figuras 3.1, 3.2, 3.3 e 3.4. Nelas, o indivíduo não aparece e nem as relações esperadas são assinaladas. Representou-se o edifício apenas. Tais representações estiveram presentes durante todo o processo. As ações do designer se pautaram quase completamente no desenho da forma, nas possibilidades de uso, nas tecnologias. Tais considerações são importantes, mas não como ponto de partida projetual, dentro do contexto do design para experiência.

As reflexões lançadas sobre esse projeto em relação ao processo de design repercutiram sobre o projeto de pesquisa desenvolvido em seguida no 
Núcleo, o D.O.S. - Designers on Spot ${ }^{89}$. Nele, o processo pôde ser repensado para que o foco de atuação do designer se concentrasse sobre as propriedades das relações entre indivíduos e objetos interativos e não no funcionamento e na forma do objeto em si. Dentro desse projeto foi possível explorar o processo de design pelos sistemas ÉOS, z.IP e PIX, apesar deste último não ter sido completamente pautado pelos conceitos do design para experiência.

A leitura crítica sobre as proposições apresentadas nesse capítulo segue a estrutura utilizada no capítulo 2, para a leitura realizada a partir dos objetos selecionados do banco de dados do Nomads.usp sobre objetos com componentes eletrônicos e processamento digital da informação. Assim, a análise dos processos de design desses projetos é feita segundo as seguintes chaves de leitura: da interação, da percepção sensorial, da construção e resgate da memória, e da comunicação.

\section{1. Éos, z.IP e Pix}

A ÉOS, o z.IP e o PIX ${ }^{90}$ estão inseridos em um projeto maior de pesquisa que é o D.O.S. - Designers on Spot. A ÉOS e o z.IP são propostas que surgiram e se desenvolveram, desde o início, pelo escopo do design para experiência. O PIX, no entanto, possui um percurso diferenciado enquanto projeto

\footnotetext{
${ }^{89} \mathrm{O}$ projeto de pesquisa D.O.S. - Designers on Spot - é financiado pela FAPESP - Fundação de Amparo à Pesquisa do Estado de São Paulo - dentro do programa TIDIA-AE - Tecnologia da Informação no Desenvolvimento da Internet Avançada - Aprendizado Eletrônico. O programa TIDIA-AE tem como objetivo desenvolver ferramentas e aplicativos e usos para o ensino e o aprendizado tendo como base a plataforma da internet avançada. Dentro desse programa, o Nomads.usp é um Laboratório Associado ao Intermídia do ICMC - Instituto de Ciências da Matemáticas e Computação da Universidade de São Paulo - um Laboratório de Desenvolvimento das ferramentas para a plataforma para internet avançada utilizada no TIDIA-AE, com o projeto D.O.S. Assim, nesse projeto, um dos objetivos é utilizar a internet avançada dentro da área da arquitetura e design.

90 Os nomes dados aos projetos de pesquisa possuem um significado. Éos é uma deusa grega, filha do Titã Hipérion e irmã de Hélios e Selene. É traduzida como aurora e media a relação entre seus outros dois irmãos, o sol e a lua. Z.IP é quase um acrônimo para Nomads Interactive Portability, se a letra $\mathrm{Z}$ for considerada como a letra $\mathrm{N}$ rotacionada. $\mathrm{O}$ nome também foi inspirado pela peça zip ou zipper que consistiu em um avanço na área dos vestíveis, no final do século XIX. PIX, vem do termo pixel.
} 
pesquisa dentro do Nomads.usp. Inicialmente não foi concebido no âmago do design para experiência, mas seu desenvolvimento em direção a um sistema para experiência se faz possível, e por tal motivo ele também é objeto de análise neste capítulo.

A ÉOS, sob um ponto de vista do desenho industrial ou mesmo do interaction design, poderia ser entendida das seguintes formas: como uma cortina, como uma superfície automatizada para bloquear a luz do sol, ou ainda, como uma proposta pautada pelo estabelecimento de uma relação positiva no contato do usuário com o objeto provido de uma instância eletrônica e informatizada. Sob a perspectiva do design para experiência, seus objetivos são outros e vão além do caráter funcional que, neste projeto, significaria sua eficiência no controle da luz solar. No design para experiência prima-se pela emergência de experiências, os produtos finais dessa abordagem. Assim, o objeto deve ser considerado como um sistema cujos elementos definidos pelo designer interagem, promovendo interrelações de características diversas segundo uma organização própria. Dessa organização entre os elementos dentro do sistema, espera-se a emergência de novas qualidades, as experiências.

A ÉOS tem como condição de existência a Unidade Experimental de Habitação 001, espaço físico do Nomads.usp, e as atividades cotidianas dos pesquisadores do Núcleo. A Unidade 001 foi construída durante um projeto de pesquisa como protótipo para habitação social e tem sido a sede do Núcleo desde 2000, ano que data a formação do Nomads.usp enquanto grupo de pesquisa. O projeto da Unidade 001 foi resultado de várias pesquisas que procuravam formular espacialidades mais adequadas aos modos de vida e aos comportamentos contemporâneos. Além disso, prezava pela escolha de sistemas construtivos e materiais de baixo custo e menos agressivos ao ambiente. As fachadas oeste e leste do edifício apresentam grandes superfícies translúcidas, cujo material de vedação são 
painéis de fibra de vidro incolor. A fachada leste foi utilizada como suporte para o PIX. A superfície da fachada oeste, sobre a qual há maior incidência de insolação, recebe o objeto interativo do sistema ÉOS, que é tangível, dotado de materialidade, componentes eletrônicos e mecânicos. Essas propriedades com as quais o objeto é dotado são responsáveis pelos comportamentos que ele pode assumir em função da interação com outros elementos do sistema ÉOS.

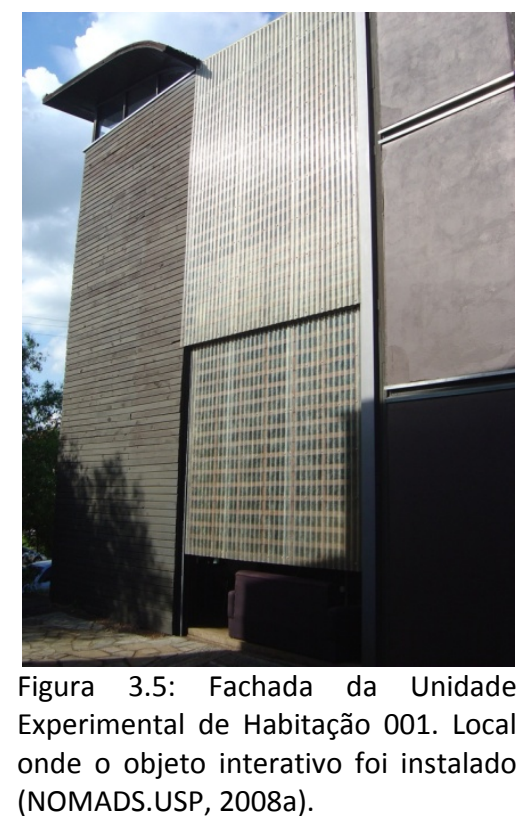

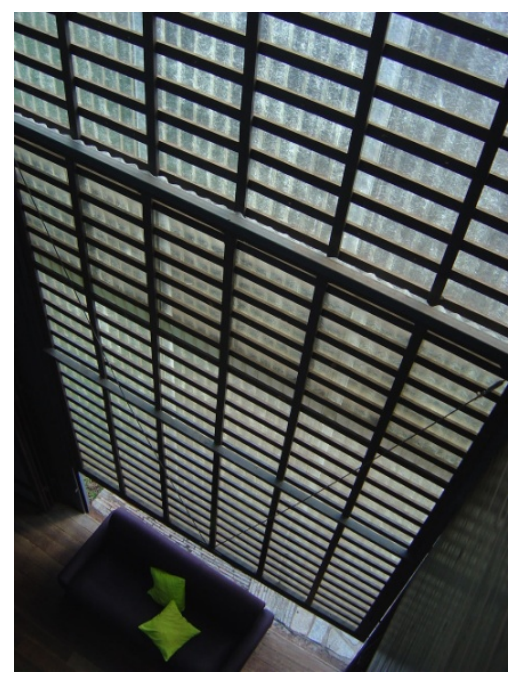

Figura 3.6: Superfície transparente de fibra de vidro vista do interior do espaço da 001 (NOMADS.USP, 2008a).

Permitindo-se realizar uma aproximação pelo pensamento sistêmico sobre a ÉOS, pode-se afirmar que ela está inserida em um sistema maior no qual a Unidade Experimental de Habitação 001 também é uma parte, se o campus universitário no qual ela se encontra for considerado o sistema maior, ou então o bairro, ou a cidade. Ou então talvez fosse possível dizer que o sistema ÉOS é um sistema dentro do sistema 001, que por sua vez está dentro do sistema campus universitário, e assim por diante. Morin apresenta níveis que os sistemas podem assumir como uma tentativa de classificação para eles, ou de enquadramento em alguma categoria. Assim o pensador aponta para cinco níveis: sistema, subsistema, supra-sistema, ecossistema, metassistema (MORIN, 2005). No entanto, como o próprio 
Morin afirma, tal classificação ou enquadramento em categorias depende do observador - no caso da ÉOS, depende do designer.

De fato, as fronteiras entre estes termos não são claras e eles mesmos são substituíveis entre si, de acordo com a focalização, o recorte, o ângulo de visão do observador sobre a realidade sistêmica em consideração. A determinação do caráter sistêmico, subsistêmico, ecossistêmico, etc., depende de seleções, interesses, escolhas, decisões, que eles mesmos dependem de condições culturais e sociais em que se inscreve o observador/conceituador (MORIN, 2005, p. 175).

Enquanto a ÉOS considera a fachada oeste da Unidade Experimental de Habitação 001 como suporte para um dos elementos do sistema, o z.IP, Nomads Interactive Portability, considera o corpo como suporte. Pensandoo como sistema, ele não se restringe a essa descrição. Compreendido por uma concepção sistêmica, o z.IP é constituído de vários elementos, no qual o objeto tangível na escala do corpo é parte do sistema e interage com outros elementos para a emergência de novas qualidades.

A questão da escala do corpo tem para o z.IP mais importância, devido às dimensões a serem assumidas pelos objetos providos de circuitos eletrônicos e pela possibilidade de mobilidade e portabilidade conferida a esses objetos. No entanto, enquanto sistema, a questão da escala é superada justamente pela característica que the confere o caráter de vestível: a portabilidade. Com essa possibilidade, o sistema pode ser a cidade se, por exemplo, for ponderada a quantidade de elementos que poderiam, potencialmente, fazer parte desse sistema. E mais, se forem consideradas nesse sistema as redes sociais de comunicação à distância na internet, esse sistema pode alcançar uma dimensão global.

Assim, tanto o z.IP como a ÉOS podem adquirir um caráter global enquanto sistema. Cabe ao designer estabelecer os limites desses sistemas, não pela imposição de regras ou restrições, mas apenas como método de observação. E mesmo assim, os limites não são claros e nem se espera que 
sejam. O que assinala um sistema como tal é justamente o caráter complexo que the é conferido como sistemas de sistemas de sistemas. É do observador a capacidade de se aproximar ou de se afastar e ampliar seu horizonte em relação ao objeto de observação.

O PIX, enquanto projeto de pesquisa, possui uma história distinta da ÉOS e do z.IP, já que ele não foi pensado desde o início como uma proposta balizada pelos princípios do design para experiência. Trata-se de uma matriz de LEDs - do inglês Light-Emitting Diode, ou Diodo Emissor de Luz que tem como suporte a fachada leste da Unidade Experiemental de Habitação 001. Essa fachada possui uma superfície transparente de 3 metros de largura por 7 metros de altura cuja vedação é feita com painéis de fibra de vidro, como foi comentado acima, fixados sobre uma grelha de madeira que funciona como estrutura para a escada do edifício.

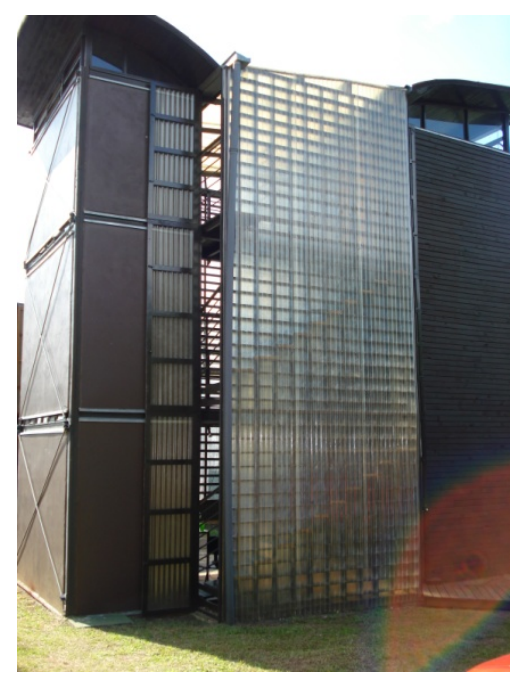

Figura 3.7: Fachada leste da Unidade Experimental de Habitação 001. Suporte para o PIX (NOMADS.USP, 2008a)
Para o PIX, essa grelha de madeira coberta por uma superfície translúcida conforma um painel de baixa resolução. Com 1200 LEDs dispostos em uma matriz formada por 10 células horizontais e 40 verticais e micro-controladores, que ditam o padrão de comportamento dos LEDs, o PIX potencializa a fachada do edifício como uma interface de comunicação. Utiliza-se o termo potencializar, pois do ponto de vista da semiótica, o edifício em si, mesmo sem qualquer tipo de aparato eletrônico, já se constituiria como uma interface de comunicação. Ele seria um signo que remeteria para significações possíveis e, portanto, já se constituiria como um processo de comunicação. 
O que faz do PIX uma interface com mais possibilidades de comunicação é sua capacidade de permitir o envio e o recebimento de mensagens por indivíduos localizados nas proximidades do edifício ou dentro dele, mas também de pessoas geograficamente distantes, graças à associação dessa interface com redes de transmissão de dados como uma intranet ou a internet.

Enquanto objeto de pesquisa e exploração, o PIX se caracteriza por ser uma plataforma de experimentações para os pesquisadores. Com uma estrutura base formada pelos LEDs e pelos micro-controladores que comandam o acender e o apagar dos diodos, é possível estabelecer padrões de comportamento para a interface por meio de programação. Os LEDs são acionados e seu comportamento alterado de acordo com as entradas (inputs) definidas pelos designers.

O PIX permite a exploração dessas entradas de formas diversas dependendo do intuito do designer. Quantidade de pessoas na Unidade 001, consumo de energia, consumo de água, condições climáticas, nível de ruído no ambiente, enfim, as possibilidades de entrada são muitas e variadas e cada uma necessita de dispositivos próprios para a captação de informações específicas e para o envio das mesmas para os microcontroladores.

Como projeto de pesquisa vinculado ao D.O.S. - Designers on Spot, a primeira entrada a ser explorada se dá por meio de uma rede de transmissão de dados, a internet. Uma interface gráfica permite que qualquer pessoa em qualquer lugar, desde que conectado à rede, consiga produzir e enviar animações que, na verdade, dão instruções para o comportamento da matriz de LEDs. E para a visualização das animações na fachada física do edifício, uma câmera registra e envia os dados também via intenet, em outra interface. 


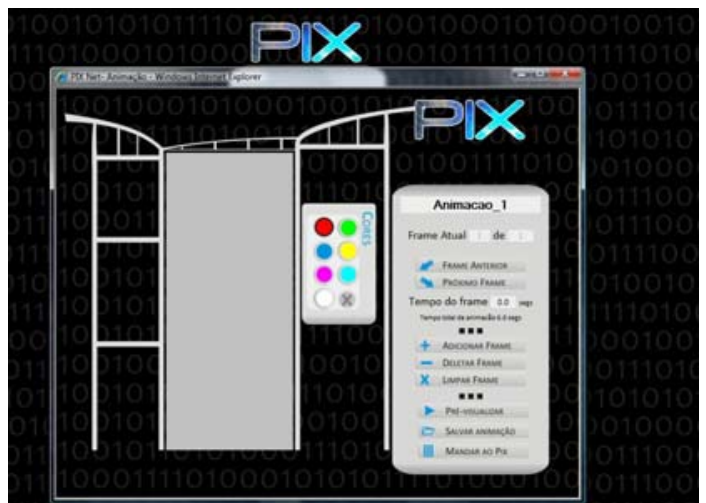

Figura 3.8: Interface web para a produção e envio de animação para o PIX (NOMADS.USP, 2008d).

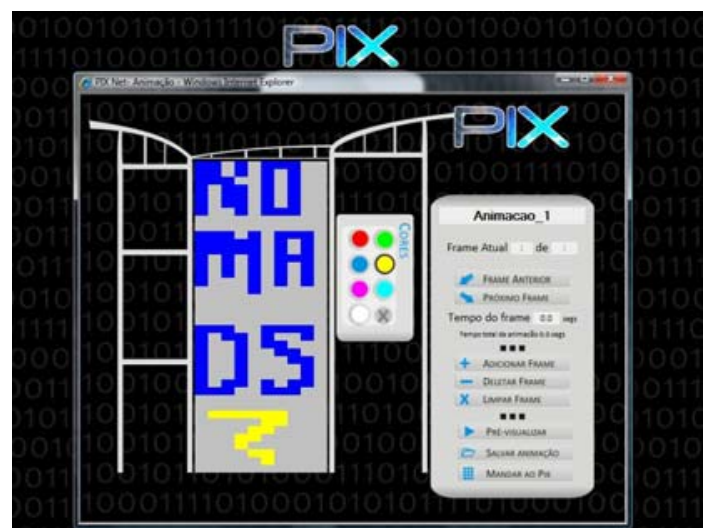

Figura 3.9: Interface web para a produção e envio de animação para o PIX (NOMADS.USP, 2008d).

No que se refere ao design para experiência, por não ter sido concebido desde seu início com esse propósito, a esfera de atuação do designer fica restrita às possibilidades de entrada e à programação dos padrões de comportamento. No entanto, é possível desenvolver sistemas para a experiência, mesmo em condições limitadas de ação. Conforme mencionado anteriormente, o observador é quem define seu campo de observação, portanto, cabe ao designer a partir do que já está dado, elencar os elementos do sistema e trabalhar as interações de forma a possibilitar a emergência das experiências.

A leitura crítica consiste em uma revisão do processo de design dos pesquisadores do Nomads.usp em relação à forma como as propriedades das relações entre indivíduo e objeto foram consideradas e como isso se constituiu em ações projetuais. 


\subsection{Das interações}

O enfoque sistêmico dado por seu entendimento como unidade complexa de Morin é princípio base para que os produtos do design para experiência sejam fomentados e foi considerando tal princípio que a ÉOS e o z.IP foram concebidos. Dado fundamental para que um sistema seja considerado como tal e ainda sob a definição elaborada por Morin, como de unidade complexa e organizada, é a presença de interações entre elementos. Pelas interações entre os elementos do sistema, surge uma organização entre eles, mesmo que momentânea. Assim, elas são condição para a consolidação da organização que pode conduzir à emergência de novas propriedades, como as experiências, como no caso das propostas desenvolvidas pelo design para experiência.

Assim, para o designer cabe, em primeiro lugar, demarcar seu campo de observação sobre o sistema, para compreender sobre quais perímetros ele trabalhará. Não significa, no entanto, que tal delineamento assuma um caráter limitador, de redução da atuação do designer sobre o sistema. Tampouco se estabelece marcações determinísticas e estanques para os sistemas. O sistema é o que o observador define como tal e seus limites são flexíveis para responder ao ponto de observação desejado.

Na ÉOS, o sistema é definido por uma condição espacial, a Unidade Experimental de Habitação 001. Talvez essa demarcação pudesse ser chamada de contexto ou cenário. Manzini (2007) recorre ao termo "cenário" para colocar esses limites para balizar as condutas do designer. 0 cenário do sistema ÉOS é composto pelas situações que ocorrem no interior da Unidade 001, com pessoas realizando atividades de pesquisas seja em grupo como sozinhas, pessoas conversando tanto presencialmente com outras como também remotamente. 
O cenário z.IP é mais abrangente. Dada a portabilidade dos elementos do sistema colocada como questão central, o espaço físico não se restringe à Unidade Experimental de Habitação 001. A portabilidade permite a locomoção para qualquer ponto, portanto, o sistema torna-se mais amplo na medida em que aumentam as probabilidades de encontro, essenciais para a interação entre os elementos que, por sua vez, tornam-se mais diversificados pela permeabilidade do qual o sistema é dotado, ou seja, a permissão dada para os elementos entrarem e saírem do sistema é maior na z.IP do que na ÉOS. Com isso o cenário abrange mais situações do que no sistema ÉOS, como pode ser visualizado nos esquemas 3.11 e 3.12 feitos para os dois sistemas.

Definidos o cenário e as demarcações para o sistema observado, o designer deve apontar para os elementos dos sistemas, mesmo que eles se alterem posteriormente. No caso da ÉOS, o sistema é constituído pelo elemento indivíduo, pelos indivíduos enquanto grupo, e pelo objeto interativo, aqui entendido como aquele dotado da capacidade de processar informações por meio de micro-controladores e agir conforme padrões estabelecidos em sua programação. No sistema z.IP, os elementos são os indivíduos, neste caso não conformados enquanto grupo, e os objetos interativos no plural, pois foram definidos três objetos a serem construídos, embora eles pudessem ser em maior ou menor número, dependendo do designer definir a quantidade de elementos a serem trabalhados. 


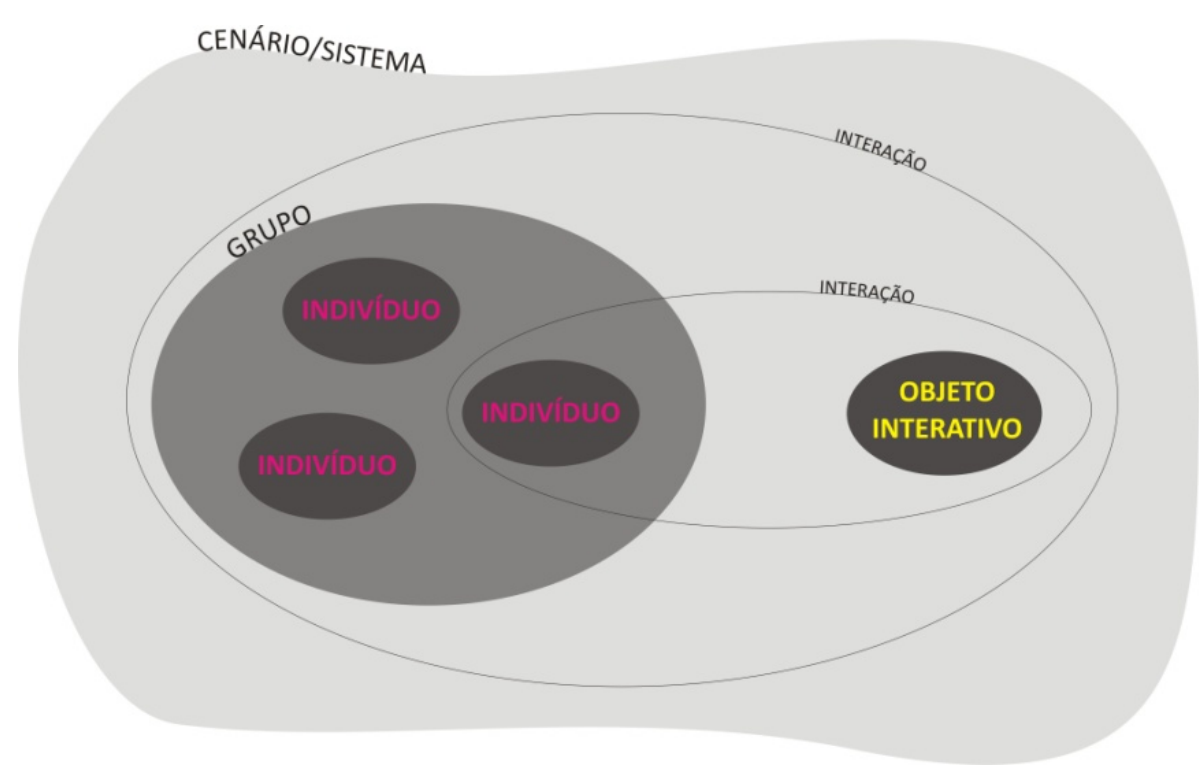

Figura 3.10: Esquema para a ÉOS, contemplando o cenário, os elementos do sistema e as interações que podem surgir na relação entre objeto e indivíduo grupo.

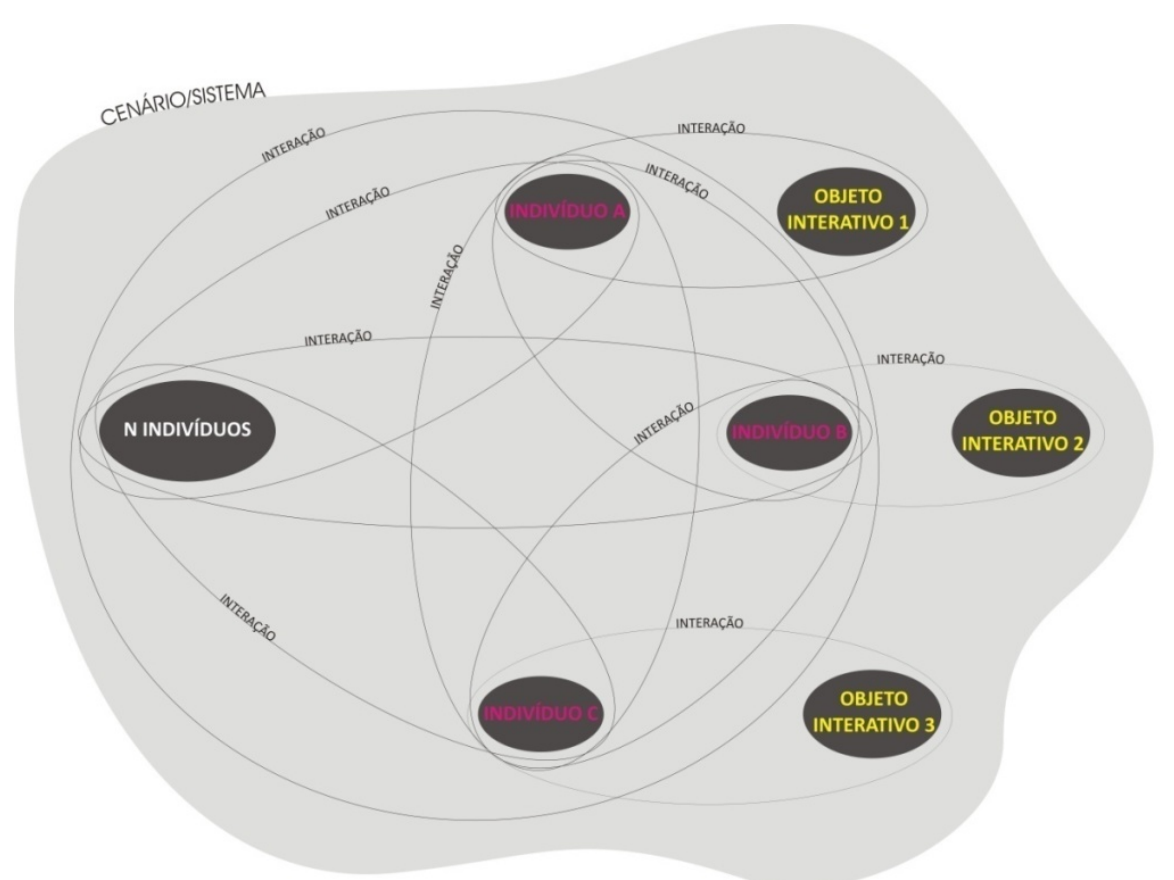

Figura 3.11: Esquema do sistema z.IP. Indica a exisência de um cenário, dos elementos do sistema e das possíveis interações.

Contudo, para haver interação é necessário um agente de agitação. É preciso dar condições para que os elementos se encontrem. Na ÉOS, os agentes de agitação seriam a própria existência do espaço físico da Unidade Experimental de Habitação 001, as atividades que ocorrem em seu interior e a incidência de luz solar no edifício. O espaço físico é o locus de encontro 
dos elementos indivíduos e objeto, as atividades realizadas no interior determinam a quantidade de pessoas e o posicionamento delas em relação ao espaço interno do edifício permitindo assim o encontro em diversos momentos com outros elementos do sistema, a incidência solar promove movimentação e agitação dos elementos, aumentando as probabilidades de encontro entre eles e, portanto, de interação.

No z.IP, as condições de encontro são fornecidas pela capacidade de locomoção dos elementos, tanto dos indivíduos como dos objetos interativos portáteis. As atividades do cotidiano também são fontes de agitação do sistema, possibilitando encontro e possíveis interações entre os elementos. O campo espacial do sistema z.IP é geograficamente ampliado, não se restringindo ao espaço da Unidade Experimental de Habitação 001, podendo alcançar dimensões globais. Mas, para o início do trabalho, os designers assumiram a escala da cidade para fazer as proposições para o Z.IP.

Os esquemas dos sistemas ÉOS e z.IP, representados pelas figuras 3.11 e 3.12, revelam as possibilidades de interação entre os elementos. Não se supõe, contudo, que todas elas acontecerão mesmo com a agitação do sistema. Para que haja interação é necessário ainda que a natureza inerente aos elementos conduza a uma situação de influência mútua entre eles. Seriam as propriedades dos elementos se articulando determinando o que interliga com o que.

Pelo diagrama do z.IP, pode-se perceber que nem todos os elementos interagem entre si. O “N INDIVÍDUOS" não está interagindo com os objetos interativos, por exemplo. Esses elementos referem-se a uma quantidade de indivíduos incalculável pelo sistema, mas que, mesmo não sabidos, são considerados como parte dele. Os objetos interativos também não interagem entre eles. A decisão de não interação, nesses casos, é dada 
pelas condições de encontro, e pela natureza dos elementos que não permitem que eles interajam.

Discorrer sobre a natureza humana envolve muitas considerações sobre aspectos diversos: ser cognitivo, emotivo, perceptivo, dotado de capacidade de se comunicar por meios distintos e complexos, capaz de processar bits de informação e agir de acordo com a situação (CSIKSZENTMIHALYI, 1991), ser imprevisível, instável, complexo em sua essência.

Algumas propriedades da relação indivíduo e objeto foram abordadas no capítulo 2, mesmo que de forma não aprofundada e seguindo a perspectiva imposta pelos olhos da arquitetura e do design. A percepção sensorial, alguns aspectos cognitivos como a memória e atenção e ainda a capacidade de comunicação. Assim, na ÉOS, as imposições do elemento indivíduo consideradas procuravam remeter a essas faculdades, embora elas não fossem as únicas presentes no sistema. Mas, de certa forma elas estão mais próximas do campo de atuação do designer, como por exemplo, estimular a percepção humana pelos sentidos, ou promover a comunicação entre pessoas.

Pela apresentação das imposições inerentes ao objeto interativo torna-se mais fácil compreender quais são as referentes à natureza humana no que diz respeito ao sistema ÉOS. As imposições da natureza do objeto interativo são definidas pelo próprio designer, considerando-as dentro do conceito de sistema, ou seja, parametrizando-as em relação ao comportamento humano e às condições de agitação do sistema - no caso, a incidência de luz solar. Portanto, as imposições da natureza do objeto são os sensores (os de presença, os foto-sensíveis e os de som), os atuadores (que seriam os motores coordenando o movimento do objeto interativo) e, talvez o mais importante, a programação dos micro-controladores, pois é por ela que o 
objeto realizará determinado movimento segundo as informações captadas por seus sensores. Aliando essas imposições com as dos indivíduos, interações podem ser estabelecidas.

Nos objetos interativos do sistema z.IP, a natureza dos elementos impõe regras de conduta da forma diferenciada quando em comparação com o sistema ÉOS. O indivíduo trabalha mais os aspectos cognitivos e da comunicação nesse sistema. Os objetos interativos do sistema z.IP possuem outros sensores, no caso, câmeras fotográficas e gravadores de som além de um GPS (acrônimo de Global Positioning System em inglês, ou Sistema Global de Posicionamento). Os atuadores imediatos são displays e caixas de som.

Mas existe uma peculiaridade no z.IP. O conteúdo registrado pelos sensores não se mostram apenas nos mostradores ou caixas de som existentes nos próprios objetos. Existe outra imposição, determinada pela natureza do objeto pelas quais as interações entre os elementos são dependentes. A possibilidade de conexão em uma rede de transmissão de dados. Com isso, o conteúdo dos objetos pode ser disponibilizado e sobreposto com outros conteúdos provenientes de outros objetos. Essa possibilidade é da natureza desses objetos, mas na verdade ela permite que haja interações fortes entre os indivíduos e não entre os indivíduos e os objetos. Os objetos podem até ser considerados como uma condição para outro sistema, formado pelos indivíduos como elementos apenas.

O PIX não foi elaborado seguindo o pensamento sistêmico como também não se pautou sobre os princípios norteadores do design para experiência, mas algumas considerações sobre o objeto podem ser feitas dentro desse contexto. O PIX é uma plataforma de experimentações para o designer cujo objetivo é explorar algumas propriedades do objeto, como as formas de 
entrada das informações que irão repercutir em alteração dos padrões luminosos.

Mas é possível pensá-lo como um elemento do sistema se em sua exploração forem consideradas as pessoas ou outros objetos que possam interagir com ele. Nessa lógica sistêmica, é preciso explorar as propriedades de cada elemento em suas relações. No entanto, as propriedades do PIX a serem trabalhadas são limitadas às formas de entrada e processamento da informação. E suas ações perante outros elementos serão sempre padrões luminosos.

As propriedades da relação entre o PIX e outros elementos podem ser trabalhadas de algumas formas. A presença das pessoas no interior da 001 poderia ser uma mensagem a ser transmitida para outras pessoas, cujos efeitos na comunicação seriam locais e geograficamente remotos, considerando a interface gráfica que permite a visualização dos padrões luminosos. Sons, que para o sistema ÉOS são entradas que irão determinar as ações do objeto interativo, também poderiam ser trabalhados na relação do objeto com as pessoas. As propriedades são variadas, no entanto, as interações com o homem dificilmente se constituirão como interações fortes pois as ações do indivíduo para com o objeto não se constituem como uma atividade flow. $O$ indivíduo não consegue ter o envolvimento e o engajamento necessário na relação física com o objeto. Nesse sentido, o PIX enquanto objeto é muito mais reativo do que interativo.

Interações fortes podem ser formadas no sistema considerando o PIX mais como meio de comunicação do que como objeto interativo. Se designers explorarem os esquemas de comunicação sugeridos no capítulo2, pode-se tentar criar relações fortes entre pessoas tomando o objeto como o mediador. 
Nos sistemas nada permanece fixo, nada é estanque. O que é imposição pode virar condição, o que é condição pode ser característica do elemento. Existem graus de incerteza quanto aos elementos e às suas naturezas, mas mesmo este desconhecido é um dado previsto. E com isso os sistemas se alteram e sempre se alterarão, pois essa é a essência deles. Eles precisam estar em desequilíbrio, pois é por essa capacidade do sistema que

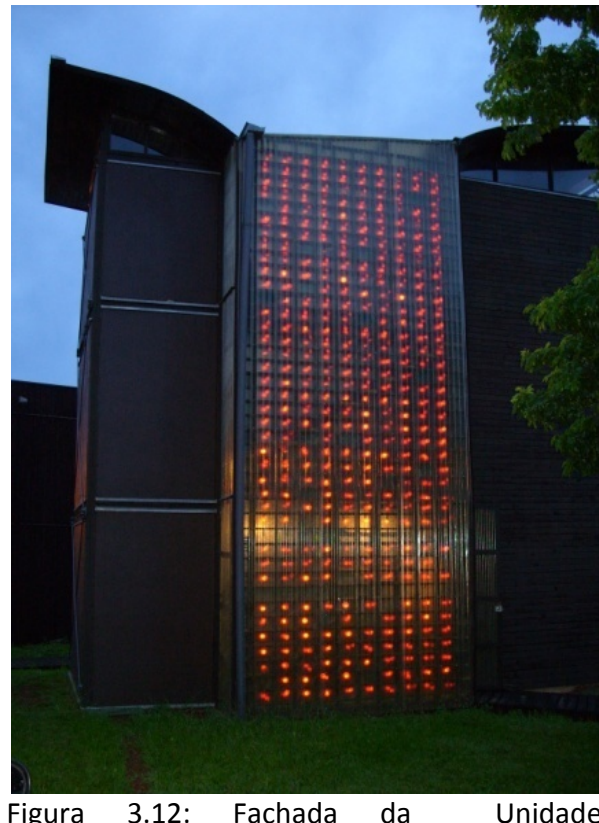
Figura 3.12: Fachada da Unidade Experimental de Habitação 001 com o PIX instalado e em funcionamento (NOMADS.USP, 2009a)

ele permite a entrada e saída de elementos, tornando-o dinâmico.

Dada a impossibilidade de previsão de todas as interações, cabe ao designer trabalhar os elementos do sistema. Os próximos itens referem-se às capacidades e faculdades do homem que podem ser considerados pelo designer de sistemas. Como dito anteriormente, não se pretende resumir o homem a tais capacidades e faculdades, mas colocá-las em evidência enquanto dado de projeto para o designer. Assim, o que se segue apresenta forma como os pesquisadores do Nomads.usp procuraram trabalhar essas características como dados para o desenvolvimento de sistemas para experiência.

\subsection{Pela percepção sensorial}

Os seres humanos, dotados de seus sensores biológicos, percebem o ambiente ao seu redor, processam a informação por sua capacidade 
cognitiva e agem, manipulam e operam por meio de seu sistema motor. A consideração desses processos para o designer de sistemas para experiências torna-se relevante visto que eles são partes constituintes da natureza humana e assim sendo, dentro do enfoque sistemático, as interações entre os indivíduos e os objetos ou ambientes dependem dessas faculdades.

Da percepção sensorial, apreciam-se os cinco sentidos: a visão, a audição, o olfato, o tato e o paladar. Conforme mencionado no capitulo 2, há estudos que incluem nos processos perceptivos o ato de perceber o próprio corpo e o percebimento dele em movimento. Os processos perceptivos, cognitivos e motores são contínuos e simultâneos. Eles não se cessam, excluídos casos no qual o indivíduo apresente alguma obstrução funcional que comprometa qualquer um desses processos.

Entender o papel que cada sensor desempenha no indivíduo durante a relação com outros elementos do sistema auxilia o designer na construção de caminhos mais estruturados que irão conduzir às interações. Os processos perceptivos foram tratados de formas distintas em cada um dos sistemas propostos. No sistema ÉOS, a prioridade recai sobre a percepção tátil e visual. Os outros sentidos podem ser trabalhados, mas a condição de encontro dada pela incidência de luz solar no interior do edifício já direciona para tal abordagem. Pessoas sentem tatilmente a exposição à incidência solar direta no interior da 001 pela temperatura.

Considerando o sistema sem o objeto interativo, os indivíduos, pela percepção dada por seus sensores táteis, se reorganizam de uma forma a não permanecerem expostos a situação que para eles é desconfortável: a incidência direta da luz solar no interior do espaço, provocando o aumento da temperatura. Com o objeto interativo, tal condição promove uma articulação de suas partes, permitindo a entrada da luminosidade ou 
bloqueando-a. Dessa forma, pelas propriedades do objeto de captar a incidência da luz direta do sol sobre o espaço e pela capacidade de transformar essa informação em dados computáveis, o objeto consegue se alterar fisicamente. A essa propriedade é associada a capacidade de percepção humana, para conformar as interações.

Mas o objeto interativo do sistema ÉOS não capta somente a incidência de luz solar. Ele também consegue captar a presença e a quantidade, bem como o posicionamento de indivíduos no espaço da Unidade 001. Por esses dados, o objeto tem uma ação, que se constitui como uma mensagem para outras pessoas presentes no espaço. Por exemplo, suponha-se que haja uma pessoa apenas na Unidade 001. A presença dessa pessoa leva o objeto interativo a realizar um determinado movimento. Quando outra pessoa entrar no espaço, ela pode não ver a pessoa, mas se dar conta da presença de mais alguém no edifício observando o padrão de comportamento do objeto interativo. Pelo processo perceptivo da visão, neste caso, uma pessoa percebe a presença de outra, sem na realidade enxergar a outra pessoa de fato, mas sim pelo movimento e posição do objeto.

No z.IP, os indivíduos são estimulados principalmente pela percepção visual e sonora. Mas neste sistema, a percepção das coisas não se coloca apenas em termos dos cinco sentidos. O que torna o processo perceptivo importante para o indivíduo não reside na sensação propriamente dita, mas sim no que essa informação pode conduzir. No z.IP, visualizar as imagens ou os sons capturados pelos objetos interativos não se constitui o ponto central. A questão que se coloca é a relação que se estabelece justamente com aquilo que não é percebido no momento imediato da captura das imagens ou sons. As ações do indivíduo, no caso seu descolamento, permitem que os objetos capturem informações sobre o ambiente, mas sob um outro ponto de vista e uma outra perspectiva. Com isso pode-se obter informações que supostamente passariam despercebidas para o indivíduo. 
Os pesquisadores, ao desenvolverem os sistemas ÉOS e z.IP, procuraram pelas formas de recepção das informações externas tanto para os indivíduos, quanto para os objetos interativos. Elas seriam as propriedades dos elementos dos sistemas manifestadas pelas relações entre eles. Contudo, no processo de design, não é possível abarcar todas as formas de percepção. É importante priorizar algumas delas, como foi feito para os processos da ÉOS e do z.IP.

No sistema ÉOS, a presença e a quantidade de pessoas foram resolvidas tecnicamente pela instalação de sensores que detectam a passagem de pessoas captando também sua presença. Os sensores são compostos por dois componentes: um emissor de luz direcionada, como um laser, e um sensor foto-sensível. Cada vez que uma pessoa passa entre esses dois componentes o feixe de luz se interrompe cortando a corrente do circuito. A instalação de dois desses sensores um ao lado do outro permite fazer a contagem das pessoas. Quando uma pessoa entra, obrigatoriamente ela deve passar pelo sensor 2 primeiro (Figura 3.13). Quando ela sai, passa pelo sensor 1 primeiro e assim pode-se saber quantas pessoas entraram e quantas saíram.

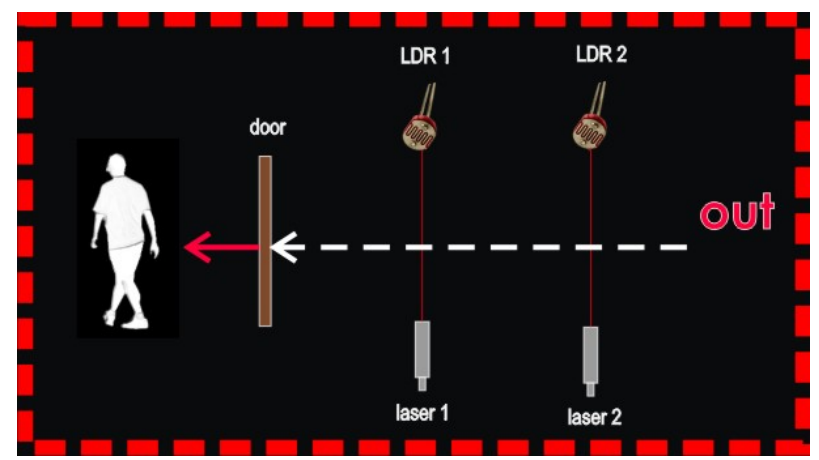

Figura 3.13: Esquema dos sensores a serem instalado na entrada da Unidade 001 para fazer a contagem das pessoas (NOMADS.USP, 2009b).

O desenvolvimento técnico acontece simultaneamente às discussões sobre as relações a serem exploradas nos sistemas. Mas ele não é para o processo 
de design um fator ao qual as decisões dos designers devem estar submetidas. $O$ intuito de se explorar a presença das pessoas como uma propriedade da relação entre elementos do sistema não foi determinado pela tecnologia representada pelo esquema da Figura 3.13 - ao contrário do que ocorre com o Brainbar discutido anteriormente, em que fica evidente que as escolhas dos designers em relação aos aspectos perceptivos e as interações que se espera entre pessoas e objetos foi condicionada a uma tecnologia existente, desenvolvida anteriormente no projeto Brainball.

É importante enfatizar que o designer deve ter consciência de suas limitações em relação à abrangência de possibilidades existentes para os processos perceptivos. Também se faz igualmente relevante considerar esses processos como contínuos e simultâneos. A percepção por um sensor não exclui a outra e uma não ocorre após a outra. Os sensores estão a toda hora recebendo informações do ambiente. Mas ao mesmo tempo, os seres humanos são seletivos e, portanto, nem todas as informações que eles recebem dos sensores são de fato processadas. E conforme Ackerman (1995) aponta, é necessário um elemento de novidade para que a atenção do indivíduo recaia sobre algo e dessa forma garantir que as informações recebidas sejam processadas pelo ser cognitivo.

Assim, os pesquisadores, ao desenvolver esses projetos, tinham como uma das preocupações o caráter reativo que o objeto poderia assumir. De fato ele reage conforme alguma informação recebida por seus sensores, mas a forma como ele deve agir e como o indivíduo apreende essa ação do objeto são fundamentais para não acabar levando o sistema a uma relação de ação e reação apenas. Por tal preocupação, questões sobre os tipos de feedbacks que o indivíduo poderia receber sobre sua ação sobre o objeto têm um papel de extrema importância. Essas questões devem ser consideradas durante o processo de design, pois é possível que as ações se tornem 
previsíveis e com isso o caráter de novidade, que dá ânimo aos sentidos e aos aspectos cognitivos do ser humano, desapareça, dificultando a formação de interações e a emergência de experiências. Nos processos de design da ÉOS e do z.IP, essas questões passaram a influenciar o modo como o objeto poderia se comportar, suas possibilidades de movimentação e sua materialidade.

Percebe-se que até o presente momento não foi falado nos aspectos formais que o objeto poderia assumir. E falou-se mais sobre o indivíduo, ou melhor, do indivíduo em relação ao objeto do que somente sobre o objeto interativo. Isso acontece porque o processo de design adotado pelos pesquisadores do Nomads.usp no desenvolvimento das peças trilhou por este caminho. O objeto interativo enquanto forma, funcionamento e materialidade é consequência desse processo de design e não a causa, ou o início da concepção projetual.

A definição dos aspectos formais certamente tem importância para o processo, mas não como uma idéia geratriz. Antes vêm as considerações sobre sistemas, a definição dos elementos e de suas propriedades, ou de propriedades mais importantes no caso do indivíduo, as considerações das ações de cada elemento dentro do sistema e também suas limitações e restrições. Enfim, até chegar à forma, materialidade, função, o designer já percorreu um longo caminho. Esses aspectos físicos do objeto podem influenciar em algumas tomadas de decisão durante a construção dos sistemas, mas eles não se constituem como a etapa inicial do design para experiência.

\subsection{Pela construção e resgate das memórias}

A memória, como processo cognitivo, apresenta-se como uma possibilidade de exploração para os designers de sistemas para experiências. Não se trata 
nesse caso de adotar técnicas mnemônicas para auxiliar o indivíduo a recuperar informações armazenadas na memória. Neste trabalho, o enfoque da memória abarca outro sentido. Conforme discorrido no capítulo 2, a memória humana pode ser utilizada como recurso para a retenção e consolidação dos eventos ocorridos nos sistemas para experiência com o intuito de se fortalecer as interações. Nesse processo, foi assinalada a característica da memória humana de reter informações que sejam carregadas de significado para o indivíduo. Para tal, sugere-se que o designer recorra à aproximação pelas considerações semióticas para compreender os processos de significação.

Assim na ÉOS se pensou na seguinte situação: uma pessoa no interior da Unidade Experimental de Habitação 001. A presença de apenas uma pessoa é captada pelos sensores do objeto interativo. Além de captar a presença dessa pessoa, os sensores associados ao objeto interativo verificam a incidência direta de insolação. $\mathrm{O}$ objeto processa essas duas informações e, conforme programação estabelecida pelo designer, movimenta-se. A imagem formada pela movimentação do objeto representa o evento que está ocorrendo no interior da 001. Suponha-se que essa pessoa vá embora. O objeto consegue perceber por seus sensores que não há ninguém, mas supondo-se que sua programação determine que ele permaneça naquela mesma configuração por três horas. Nesse período, outra pessoa entra no espaço físico da 001 e ao observar o objeto interativo e o padrão de seus componentes físicos transmite uma mensagem: que alguém esteve naquele espaço e saiu dele no máximo há três horas. Isso supondo também que o objeto leve um certo tempo para assumir outra configuração após captar informações novas, referentes à presença de um novo indivíduo no local.

Isso é possível se as pessoas entenderem os padrões de comportamento do objeto interativo, associando suas configurações à presença de pessoas ou atividades no espaço. Caso contrário, tanto os padrões de comportamento 
do objeto bem como o porquê de seus movimentos significarão pouco ou absolutamente nada para as pessoas. Eles podem ter significado para uma pessoa e, ao mesmo tempo, não representar nada além de coisas se movimentando no espaço para outra pessoa, sem que se estabeleça a transmissão de uma mensagem.

Na ÉOS, portanto, faz-se necessário estabelecer códigos que, segundo Cherry, "são inventados para algum propósito específico e obedecem a regras explícitas" (CHERRY, 1971). Sem o conhecimento desse sistema de códigos pelas pessoas que passam pelo espaço físico da 001, a comunicação não pode ser realizada. Aspectos sobre como foram consideradas a questão da comunicação no processo de design da ÉOS serão abordadas em profundidade no próximo item.

$\mathrm{Na}$ ação projetual, os designers utilizaram as narrativas como estratégia para definir o cenário ou, pelos conceitos de interação, as condições de encontro entre os elementos do sistema. As figuras abaixo representam essa tentativa de se narrar situações para determinar que propriedades dos elementos do sistema poderiam ser exploradas.

Na narrativa 1 (Figura 3.14) pressupõe-se a existência de uma pessoa no interior do espaço da 001. Conforme já descrito, a presença de uma pessoa associada à incidência direta da luz do sol são captadas pelos sensores e codificadas para os micro-controladores. Pela programação inserida nesses micro-controladores, os atuadores, que no caso da ÉOS são pequenos motores, promovem a movimentação de componentes físicos do objeto interativo segundo um padrão determinado pelos pesquisadores. Se há uma pessoa no interior da 001, mas não há incidência solar direta, o padrão de comportamento do objeto interativo dado pelo posicionamento dos componentes físico do objeto interativo é outro. 


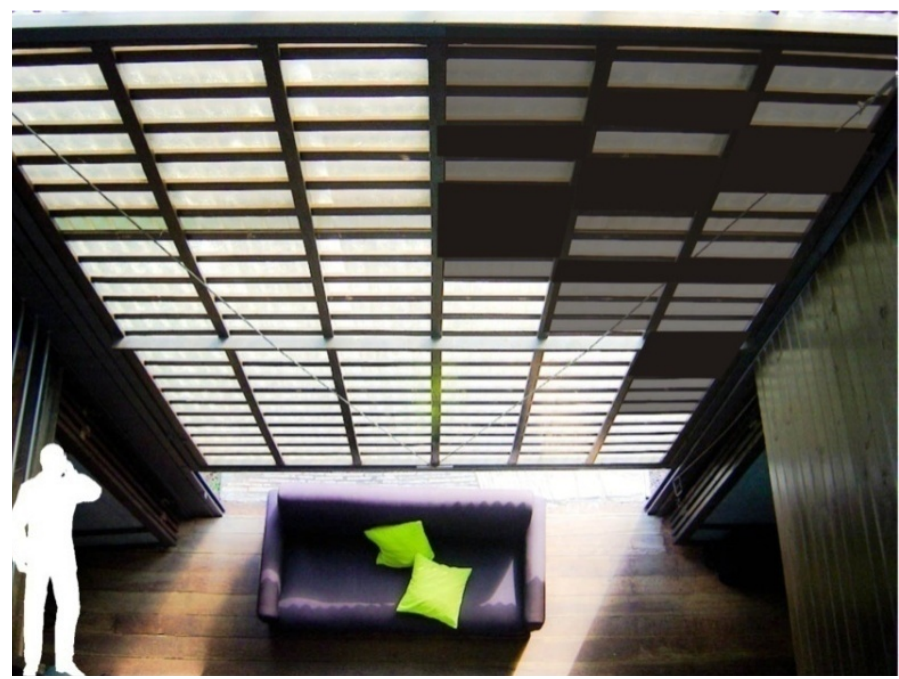

Figura 3.14: Narrativa 1 - há uma pessoa no interior do espaço doméstico e há incidência solar direta na superfície transparente da fachada do edifício. Para essa situação a programação inserida nos micro-controladores vai determinar o posicionamento dos componentes físicos do objeto interativo pelo envio de informação para os atuadores.

Suponha-se que não haja uma pessoa apenas, mas um grupo de pessoas, todas no mesmo local do edifício, conversando, trabalhando, movimentando-se ou realizando quaisquer outras atividades que pressupõem a presença de várias pessoas. Trata-se da Narrativa 2 pensada pelos pesquisadores. Essa situação, associada à presença ou não da incidência solar direta na fachada promove outro padrão de comportamento do objeto interativo.

A existência de muitas pessoas no espaço também promove um aumento do ruído no espaço, seja pela comunicação oral entre as pessoas como também por outras formas de se produzir sons, como a própria movimentação das pessoas, do mobiliário existente, dos autos-falantes dos computadores, o barulho emitido por ferramentas (visto que as atividades de pesquisa do Nomads.usp também envolvem prototipagem e que em muitos casos é realizada dentro do espaço da 001). Com isso, é dada outra entrada de informação para o objeto interativo codificar: a frequência e a intensidade das ondas sonoras. Dessa forma, outra propriedade do 
elemento indivíduo desde sistema é explorada. Sua capacidade de comunicação, neste caso, via linguagem oral, é uma característica que poderia auxiliar na interação com o objeto interativo. Contudo, enfatiza-se que tal característica somente é considerada pelos sensores do objeto interativo se a ela estiver associada a quantidade de pessoas presentes.

Na narrativa 1, na qual há apenas uma pessoa, a informação referente ao ruído não é processada pelo objeto interativo. Isso significa que o ruído que uma pessoa faz no interior da 001, não é relevante enquanto informação capaz de influenciar na organização existente. Na narrativa 2, a consideração do ruído, associada a outras informações, promove a movimentação dos componentes do objeto interativo. Essa movimentação poderia ser tão intensa e constante que o próprio objeto interativo emitiria seu próprio som que poderia ser considerada como uma mensagem para as pessoas, como se ele estivesse conversando com elas e dizendo "vocês estão fazendo muito barulho! Se assim continuar eu também vou emitir tanto ruído até chegar a uma altura insuportável para vocês!" Trata-se de uma possibilidade de compreensão da mensagem. Depende do designer definir o que poderia ser a mensagem e também depende das pessoas compreenderem esse sistema de códigos para que a comunicação se complete. 


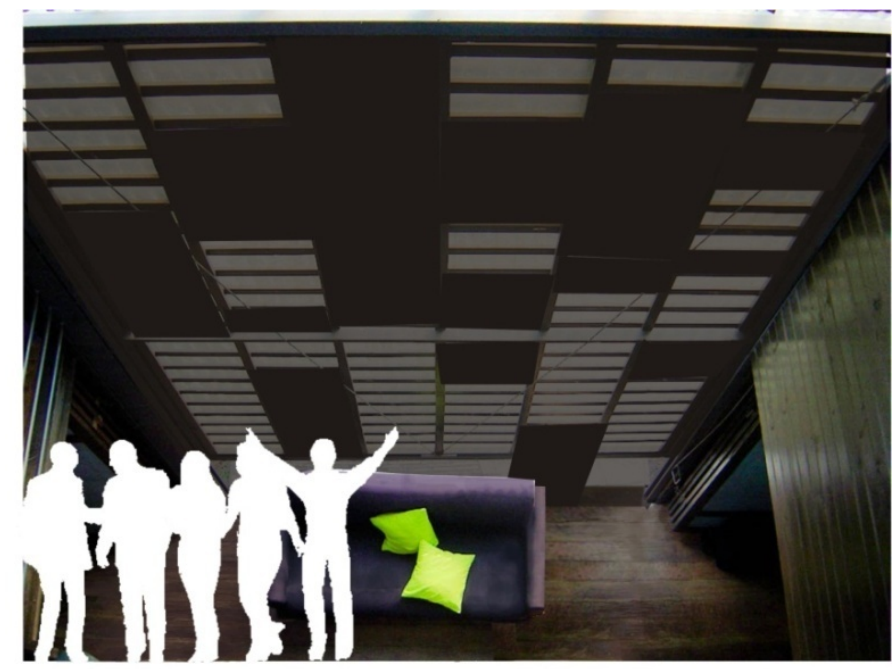

Figura 3.15: Narrativa 2 - um grupo de pessoas no mesmo local do edifício realizando atividades diversas. Se as pessoas estão provocando o aumento de ruído no ambiente, e se há incidência de luz solar direta, o objeto interativo tem um padrão de comportamento. Se não há incidência de luz solar direta, o padrão é outro e se há pouco ruído, o movimento e a posição dos componentes físicos são outros.

Há ainda mais uma situação possível desenvolvida pelos pesquisadores do Núcleo. Se existir apenas uma pessoa no edifício, trabalhando isoladamente e em silêncio na cota de nível $+2,50 \mathrm{~m}$ ou na $+5,00 \mathrm{~m}^{91}$, os sensores captam a presença dessa pessoa nesses pavimentos e modificam a disposição dos componentes do objeto interativo. Quando uma outra pessoa entra no edifício, ela é possível como saber se há alguém nos pisos superiores ou não. Com a decodificação da informação captada do pavimento onde a pessoa se encontra em linguagem visual (na composição das peças que se movimentam do objeto interativo) a pessoa que entra no edifício recebe a mensagem enviada, involuntariamente, por aquele que está trabalhando só. Assim, a pessoa que entra no edifício sabe que existe alguém em determinado pavimento do edifício, desde que ela compreenda os códigos envolvidos nessa comunicação.

\footnotetext{
${ }^{91}$ A Unidade Experimental de Habitação 001 possui três pavimentos: o térreo, ne cota 0,00; o segundo pavimento, ne cota $+2,50$; e o terceiro, ne cota $+5,00$.
} 


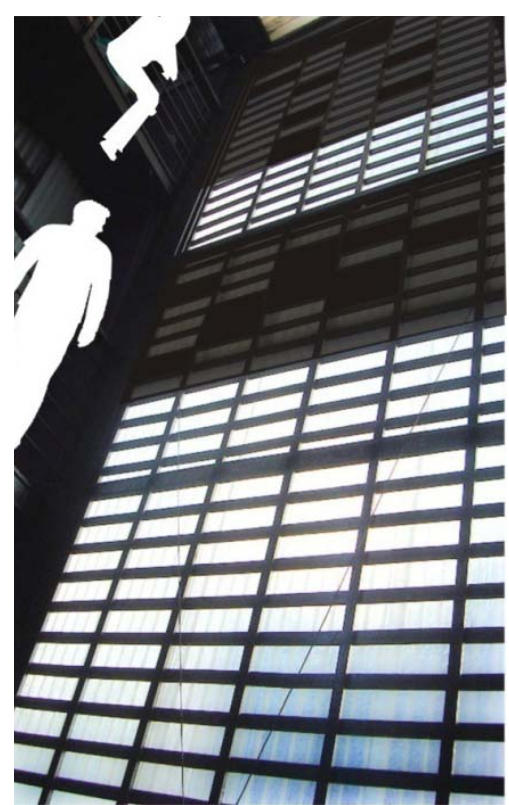

Figura 3.16: Narrativa 3 - concentra-se sobre a possibilidade de comunicação entre uma pessoa que está nos pavimentos superiores da habitação com pessoas que entram no edifício e não consegue visualizá-las. Como a fachada transparente do edifício perpassa os três pavimentos da Unidade Experimental de Habitação 001, o sistema de códigos poderia, por exemplo, indicar se há alguém na cota $+5,00$ m com uma disposição dos componentes físicos do objeto interativo se concentrasse na superfície mais alta da fachada transparente.
A questão técnica pode estar presente no momento em que as narrativas são construídas, mas não as determina. Por tal motivo, pode-se perceber pelas narrativas que o funcionamento do objeto interativo, bem como os sensores que nele estarão presentes, os circuitos elétricos, os micro-controladores e os atuadores não estão completamente definidos, bem como a forma como o objeto poderá se movimentar.

Também não é definida nenhuma materialidade, embora uma condição sobre ela deva ser assinalada: que um dos materiais a ser utilizado seja um bloqueador solar, afinal, a incidência da luz do sol é uma das condições para a existência do sistema. Havendo o intuito de se trabalhar com esse dado, ele deve ser capaz de influenciar na organização do sistema, de modo que o objeto interativo possa permitir tanto a entrada quando o bloqueio da incidência direta da luz solar. Contudo, não é ainda nesse momento que a escolha dos materiais se faz presente no processo de design. Também não é nesse momento do processo de design que se aponta para questões referentes á forma que esse objeto assumirá.

Nessa etapa do processo de design os esforços recaem sobre a criação e a enumeração das possibilidades de situação. A partir da definição de quais situações são para o designer as que mais apresentariam condições para a 
constituição das interações entre indivíduos e objeto interativo ou entre os indivíduos apenas, é que se pode dar o próximo passo para a investigação das possibilidades técnicas, da forma e da materialidade. Entretanto, cabe ressaltar que esse processo de design não é linear. Após definidas as situações consideradas mais expressivas para a idéia de interação, é possível que novos dados surjam durante a exploração de soluções técnicas, levando à sugestão de outras abordagens. Com isso, o foco voltase novamente às narrativas, para compreender o que significaria inserir um novo dado a ser trabalhado pelos designers enquanto relações no sistema.

O emprego das narrativas como estratégia a ser utilizada pelo designer para definir os cenários, para compreender e elencar algumas propriedades dos elementos do sistema a serem trabalhadas nos sistemas para experiência é um recurso que pode ser amplamente explorado no processo de design.

A narração como ação para o designer também foi recurso para o z.IP. Para o objeto 1 , os designers imaginaram que o caminho percorrido pelas pessoas poderiam ser um dado importante a ser explorado. Assim, os designers pensaram na seguinte situação: conforme o indivíduo caminha, o traçado de seu deslocamento vai sendo registrado. O percurso rotineiro realizado pelo indivíduo representará para ele uma centralidade. Ao sair desse caminho, o objeto reconhece o afastamento relativo ao trajeto usual e emite um sinal luminoso cujo padrão se altera conforme o indivíduo vai se distanciando de sua centralidade. Essa informação o indivíduo recebe simultaneamente à sua movimentação pelo espaço urbano. 


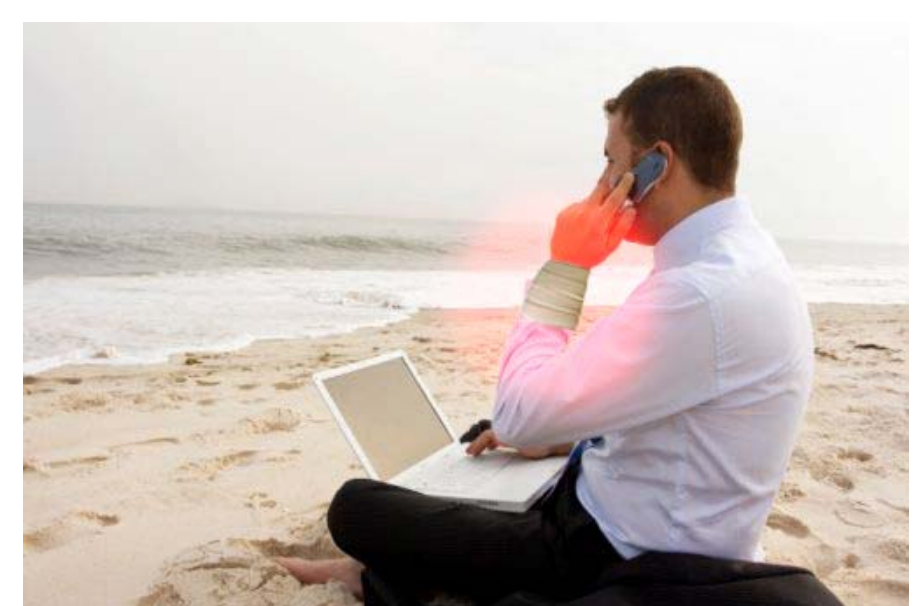

Figura 3.17: Objeto 1 do sistema z.IP. Com um GPS acoplado e um emissor de mensagem luminoso, a pessoa vai recebendo a informação de quanto ela está se distanciando de sua centralidade, estabelecida por suas rotas rotineiras. (NOMADS.UPS, 2008e).

No entanto, existe uma mensagem que ele somente receberá se conectar seu objeto a um computador. Por meio de uma interface gráfica ligada a uma rede de transmissão de dados o indivíduo poderá visualizar o caminho percorrido durante o período de registro do objeto interativo, sobreposto a um mapa ou imagem de satélite. Essa mensagem será dotada de significado se o indivíduo desejar se envolver com ela. Para isso, ele precisará recorrer à memória como uma forma de verificar, por exemplo, se o caminho por ele percorrido é de fato o registrado pelo objeto e em que momento ocorreu a ação. E se a interface indica que ele passou em determinado lugar do qual ele não se lembra, ele precisa rememorar suas ações durante o período de registro: por onde ele passou, o porquê de ter passado em tal lugar, para onde foi depois e por qual motivo. 


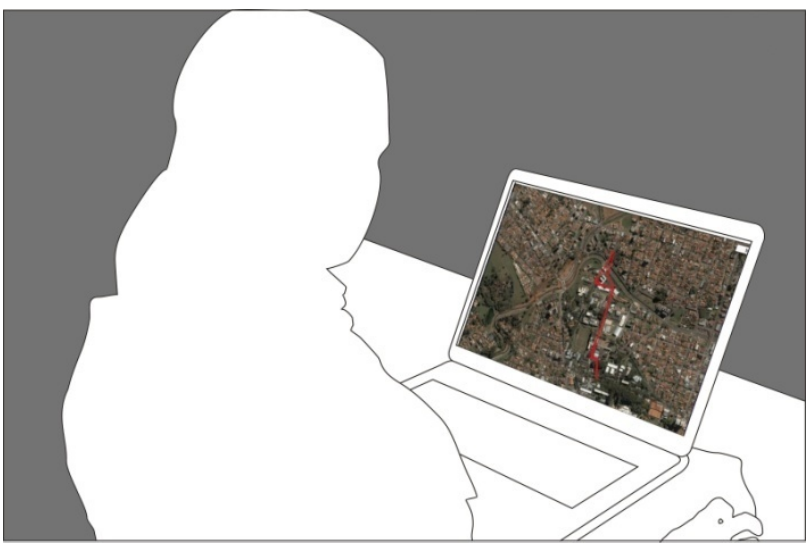

Figura 3.18: Interface gráfica no sistema z.IP que permite a visualização do caminho percorrido.

Além disso, a interface gráfica, conectada a uma rede de transmissão de dados, permite a visualização não apenas do caminho percorrido pelo indivíduo, mas também os deslocamentos realizados por outras pessoas que também possuam o objeto e que tenham inserido os dados registrados na interface. Essa capacidade de se visualizar não apenas o próprio caminho, mas também de outros, cria um estreitamento das relações, permitindo a comunicação entre várias pessoas envolvidas pela noção de centralidade. O que um indivíduo entende como sendo central, pode não corresponder às centralidades apontadas pelos percursos de outras pessoas e, talvez, ao registro do seu próprio deslocamento na cidade. Além disso, pessoas diferentes poderiam estar percorrendo o mesmo caminho e encontrando-se diversas vezes em seus trajetos, mas somente tomando conhecimento uma da outra após visualizar a coincidência de rotas através da interface. 


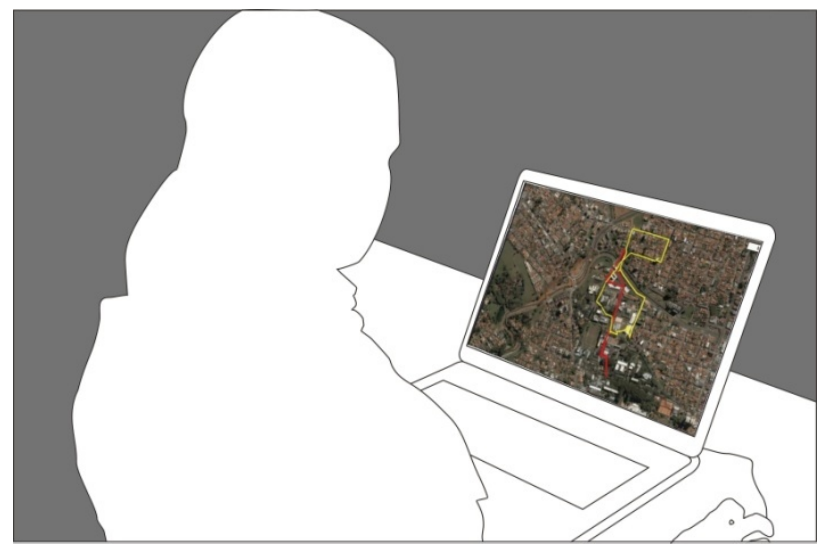

Figura 3.19: Interdace gráfica no sistema z.IP. Cruzamento dos caminhos percorridos pelas pessoas.

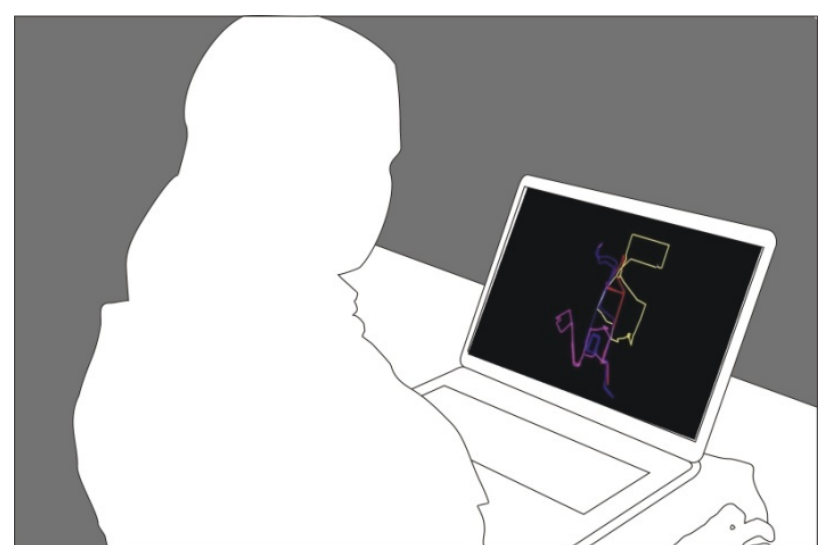

Figura 3.20: A interface também permitiria ao indivíduo retirar as referências cartográficas e visualiza apenas os caminhos percorridos. Dessa forma, as pessoas teriam que recorrer a sua memória para identificar sua própria rota e também as das outras pessoas em função do conhecimento espacial que se tem da cidade ou do bairro.

Os outros dois objetos que compõem o sistema z.IP também envolvem o processo de significação e, por conseguinte com a memória também. Entretanto, aspectos da semiótica não foram contemplados no processo de design, apesar deste trabalho sugerir a exploração da teoria dos signos para o desenvolvimento de artifícios que desencadeiem um processo de significação. No caso da ÉOS e do PIX tal abordagem semiótica está presente sob duas formas distintas, evidentes e propositais. Os objetos interativos enquanto forma, materialidade, possuem sua carga de significação acoplada. 
Eles também se constituem como canal de comunicação entre indivíduos, sendo que as mensagens transmitidas também carregam signos que estão relacionadas com um interpretante que pode ser outro signo também e assim por diante. Na ÉOS, os padrões de comportamento poderiam promover a movimentação da parte mecânica do objeto interativo de forma a construir signos que desencadeariam todo um processo de significação no indivíduo.

No PIX, por sua característica de display de baixa resolução, a conformação luminosa dada pelos padrões de comportamento estabelecidos pela programação são signos a serem explorados em vários aspectos. Tanto na ÉOS como no PIX, os signos transmitidos pelo objeto interativo, ou seja, enquanto canal de comunicação, podem estar baseados em um sistema de códigos convencionados ou não. Conforme já fora descrito neste item, os pesquisadores optaram pela constituição de um código próprio para a transmissão de mensagens, o que pressupõe que os indivíduos do sistema devam ter conhecimentos desses códigos. O PIX desfruta da liberdade de trabalhar ora com signos convencionados, como a linguagem escrita, ora com códigos próprios, desde que as pessoas saibam decifrá-los - sem o que todo o processo de significação ficaria comprometido.

A exploração da memória nos outros dois objetos que compõem o sistema z.IP é conseqüência da abordagem escolhida pelos pesquisadores do Nomads.usp. Ao trabalhar com foco na percepção das informações que muitas das pessoas ignoram ou ainda com o conhecimento de outras pessoas fazendo atividades distintas ou similares ao mesmo tempo, os designers acabaram inserindo na discussão a possibilidade do indivíduo recorrer aos processos de significação e de recuperação de informação na memória. 
$\mathrm{O}$ objeto 2, por exemplo, registra fotograficamente aquilo que no momento não está sendo visto pelo indivíduo. As imagens registradas podem ser descarregadas em uma interface gráfica que disponibilizará a sequência de fotos tiradas e que pode suportar os registros de várias pessoas que possuam o objeto. Ao depositar na interface suas imagens não percebidas de

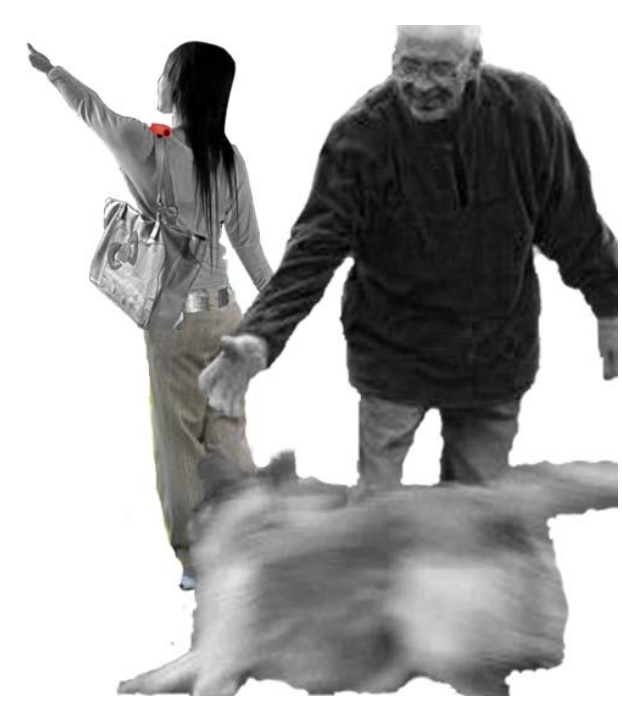

Figura 3.21: 0 objeto 2 registra momentos e situações que passam de forma depercebida pelas pessoas. (NOMADS.USP, 2008e).

imediato, o indivíduo ativará sua memória, tentando se lembrar dos lugares por onde ele passou, ou tentando decifrar a própria imagem registrada já que ele não possui o controle visual do registro.

O objeto 3 envolve mais os processos de significação e de construção da memória sobre algo do que o resgate de informação. Tem a capacidade de registrar imagens e sons em horários específicos do dia. O momento do registro é constituído de uma foto e de uma gravação dos sons do ambiente num certo momento, porém de forma fragmentada. Em um período de um minuto de gravação, o sensor capta o som, mas seu registro se dá intercalando dois segundos de gravação e dois segundos de silêncio, reiniciando e interrompendo a gravação, até completar os sessenta segundos. A imagem registrada também pode ser fragmentada, mas em outro sentido. Ela se configura como uma pequena amostra do ambiente captado, podendo apresentar distorções e até ser de difícil compreensão. 

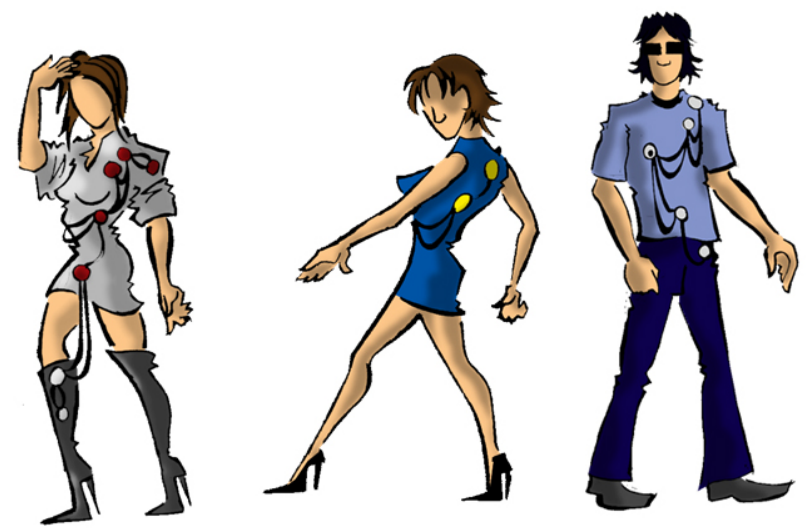

Figura 3.22: Objeto 3. Registra sons e imagens fragmentadas das atividades das pessoas (NOMADS.USP, 2008e).

Ao depositar todas as imagens e sons registrados durante o dia, a pessoa terá acesso a informações que se referem a suas atividades cotidianas e que podem até parecer sem significado algum. $O$ indivíduo precisaria dotar cada imagem e som registrado de significado para compreendê-las. Pode também comparar seus registros com os de outras pessoas, procurando igualmente significados para as imagens e sons depositados por outros e construir relações entre eles. Mesmo não sendo o foco primeiro dos designers, a idéia de memória e significação foi aos poucos sendo entendida como uma estratégia a ser explorada nas relações entre indivíduos e objetos e entre os próprios indivíduos.

A idéia de narração no z.IP e na ÉOS se faz presente como estratégia para definição de cenários, condições de encontro dos elementos do sistema e de suas propriedades. Contudo nos objetos do z.IP a questão das narrativas também toma forma enquanto meio para se recuperar memórias de eventos passados. Na ÉOS o recurso da narrativa no processo de design se limitou a explorar as propriedades dos elementos envolvidos no sistema, visto que o cenário já estava pré-determinado. No Z.IP, foi necessário construir todo o cenário e as condições de encontro necessárias para a constituição das interações. 
Todavia, a exploração das narrativas como estratégia para o designer não se encerra no momento em que os cenários, as condições de encontro e os elementos dos sistemas são definidos. Sua utilização pode se estender por vários momentos do processo de design como, por exemplo, na exploração de outras características dos elementos dos sistemas e de outros esquemas de comunicação e até mesmo de outros cenários ou condições de encontro.

No sistema ÉOS não foram abordadas as formas de comunicação remota, mas uma situação incluindo essas considerações poderia ser investigada. Suponha-se que o cenário primeiramente estipulado como a Unidade Experimental de Habitação 001 pudesse ser ampliado, envolvendo, como no caso do z.IP, qualquer outro lugar do planeta com acesso a uma rede de transmissão de dados como a internet. Que situações poderiam ser criadas em função dessa nova propriedade inserida ao sistema? As narrativas poderiam ser utilizadas como um meio para os designers compreenderem a implicações envolvidas com a inserção de novas condições de encontro entre elementos do sistema.

E isso não apenas porque se trata de experimentos no âmbito da pesquisa acadêmica. As Tecnologias de Informação e Comunicação permitem a apropriação de outras características, pela reprogramação dos microcontroladores, inserindo outros sensores e atuadores, a possibilidade de transmissão de informação utilizando a internet, entre outras propriedades. Embora também se possam alterar propriedades de objetos que não contemplem dispositivos eletrônicos e de processamento digital da informação, nos objetos interativos as possibilidades se ampliam. Com isso, as relações entre objeto interativo e indivíduos podem ser modificadas constantemente. 


\subsection{Pela comunicação}

Aspectos relacionados à comunicação já foram mencionados nos itens anteriores deste capítulo, que procura fazer uma análise do processo de design de propostas desenvolvidas no Nomads.usp. As categorias de análise se referem às estratégias de abordagem da relação indivíduo e objeto que foram elaboradas por este trabalho como possibilidades para a ação projetual a serem adotadas pelo designer que tenha a intenção de desenvolver proposições segundo os conceitos do design para experiência.

Embora cada categoria contemple um aspecto diferente da relação entre indivíduo e objeto, elas não são estanques e não se encerram em si mesmas. Elas se intercambiam e às vezes podem fazer parte de um mesmo processo como, por exemplo, ocorre com a percepção, a cognição e a comunicação humana. Por tal razão, nos itens anteriores deste capítulo, aspectos da comunicação estão presentes assim como elementos das outras categorias de análise também são abordados neste item.

A abordagem das questões da comunicação humana pode parecer redundante por sua apreciação em outros tópicos deste capítulo. Contudo, neste item o foco recairá sobre os esquemas de comunicação e sobre a referência espacial e temporal trabalhados pelos designers no projeto ÉOS, z.IP e PIX. Dos esquemas sugeridos no capítulo 2, alguns foram os optados pelos pesquisadores do Nomads.usp para trabalhar a comunicação humana mediada por objetos interativos e pelas tecnologias disponíveis de informação e comunicação.

Na primeira narrativa feita para o sistema ÉOS, cuja situação envolve um indivíduo, uma condição externa dada pela incidência solar direta e o objeto interativo, a comunicação entre as pessoas é explorada pelos designers segundo o esquema indivíduo/objeto interativo/indivíduo, sendo 
que o indivíduo pode enviar e receber mensagens decodificadas do objeto interativo, como também um indivíduo pode emitir uma mensagem e outro indivíduo receber a mensagem do objeto.

É possível também uma comunicação gerada pela existência de um grupo, que para o objeto interativo é uma mensagem captada por seus sensores. Associada com a condição externa, a incidência ou não da luz solar direta na fachada, essas mensagens transformam-se em sinais que são processados e transformados novamente em mensagens, porém com outra linguagem. 0 mesmo grupo que enviou a mensagem a está recebendo de volta pelo objeto interativo. Trata-se do esquema grupo de indivíduos/objeto interativo/grupo de indivíduos. A figura 3.20 ilustra os esquemas:
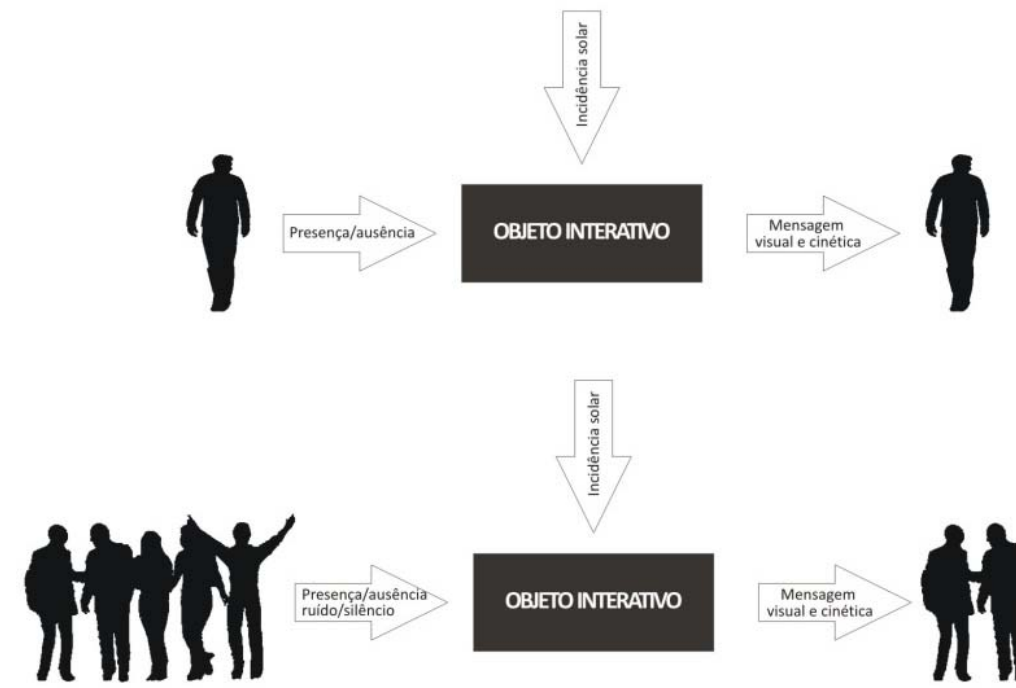

Figura 3.23: Esquemas de comunicação para as pessoas do sistema ÉOS

Embora no segundo esquema se considere uma relação de comunicação na qual tanto o emissor e o receptor das mensagens sejam um grupo de indivíduos, enfatiza-se que no momento da recepção a mensagem é apreendida individualmente. Entretanto, considera-se o esquema com grupos de indivíduos nos extremos da cadeia comunicativa, pois o processo de comunicação não se encerra no momento da recepção da mensagem. Após a recepção, esperam-se novos comportamentos das pessoas 
presentes, ou seja, novas mensagens a serem codificadas pelo objeto interativo que somente serão captadas enquanto comportamento de grupo.

Aos esquemas estabelecidos também deve estar associada a relação espacial e temporal do processo de comunicação. Os designers focaram na consideração espacial da comunicação dada pela condição em que a codificação das mensagens em sinais, o canal de transmissão deles e a decodificação novamente em mensagens, seja feita no mesmo espaço físico. O objeto da ÉOS assume o papel de codificador, canal e decodificador de mensagens. A temporalidade pode ser tanto síncrona e assíncrona. As narrativas 1 e 3 descritas no item anterior são as que melhor exemplificam a situação em que a comunicação é assíncrona. A narrativa 2, das mensagens emitidas por um grupo, fornece o exemplo para a comunicação síncrona. Entretanto, todas as situações propostas pelos designers podem abranger ambas as formas temporais de comunicação.

Poucos foram os esquemas de comunicação explorados na ÉOS. Todavia, é possível ampliar e explorar outras possibilidades. No item anterior foi comentada a possibilidade de inserção de outros objetos interativos à ÉOS ou o uso de aparatos já existentes para a comunicação. Essas novas condições dadas para o sistema permitiriam outras formas de comunicação. Além disso, pode-se também dotar o objeto interativo da capacidade de utilização de uma rede de transmissão de dados como a internet ou mesmo uma intranet e, com isso, permitir que pontos remotos também passem a fazer parte do processo de comunicação. Assim, o processo da comunicação entre as pessoas deixaria de ser centralizado no objeto interativo permitindo que outros aparatos assumissem as capacidades de codificadores, canais e decodificadores de mensagens. 
O sistema z.IP trabalha os esquemas de comunicação de forma muito mais complexa, proporcionando a associação de vários deles. Além disso, permite a exploração espacial e temporal do processo de comunicação que perpassa por todas as possibilidades, síncrona, assíncrona, remota, ou local.

A comunicação do z.IP segue os esquemas:

- indivíduo/ objeto interativo/ individuo;

- indivíduo/ objeto interativo/ tecnologia existente/ indivíduo;

- indivíduo/ tecnologia existente/ indivíduo;

- indivíduo/ objeto interativo/ tecnologia existente/ objeto interativo/ indivíduo.

Esses esquemas se confundem entre si e geralmente estão relacionados a um mesmo processo de comunicação. Associadas a esses esquemas estão as referencias espaciais e temporais que assumem todas as possibilidades, síncrona, assíncrona, remota e local.

O esquema indivíduo/ objeto interativo/ indivíduo foi trabalhado pelos designers do Nomads.usp como a relação de comunicação entre o individuo emitindo e recebendo uma mensagem através do objeto interativo. As mensagens emitidas pelo indivíduo nesse caso são provenientes da condição de portabilidade dada aos objetos interativos. A locomoção das pessoas produz as mensagens, mesmo que elas não tenham conhecimento do conteúdo dessas mensagens.

Os indivíduos podem conectar o objeto interativo em seus computadores pessoais e depositar os registros do dia em uma interface gráfica. $\mathrm{O}$ objeto 
interativo codifica a mensagem em sinal e transmite para o computador pessoal. Envia o sinal por meio de uma rede de transmissão de dados como a internet e o decodifica em sinal luminoso das telas dos computadores através da interface gráfica que também reúne todas mensagens enviadas. Ao final, o indivíduo não recebe apenas a mensagem que ele enviou, mas também de todas as pessoas que postaram os conteúdos de seus objetos interativos. As mensagens têm ação local e síncrona no momento do registro. Posteriormente, com a utilização de computadores, assumem o caráter assíncrono e remoto.

Os esquemas de comunicação do PIX não são muito variados. Envolve principalmente a comunicação entre indivíduo/objeto interativo/indivíduo. Entretanto, apresenta uma peculiaridade nesse esquema e também nas condições espaciais do processo de comunicação que não está presente nas outras propostas. O PIX enquanto objeto material mantém para com as pessoas uma relação de comunicação localizada, ou seja, ele codifica, transmite e decodifica as mensagens no mesmo espaço físico. Portanto, o PIX, como objeto, assume essas características do processamento das mensagens.

No entanto, há uma instância no PIX que é representada pelo esquema indivíduo/equipamento eletrônico existente/objeto interativo/ indivíduo. 0 PIX é constituído de uma interface gráfica disponibilizada na internet que permite que uma pessoa utilizando um computador em qualquer lugar do planeta possa interferir no objeto físico. Apesar do indivíduo receber de volta a sua mensagem por um padrão luminoso no objeto interativo, ele somente pode visualizar esse padrão por meio de um vídeo em tempo real na interface gráfica.

Ele não está vendo de fato o objeto interativo e sim uma imagem que o representa. Dessa forma, a esse esquema acrescenta-se uma decodificação 
da decodificação da mensagem. Da mensagem transformada pelo objeto sob uma linguagem visual formada por padrões luminosos é novamente codificada pela filmadora, transformada em sinal, enviada por um canal de comunicação - no caso a internet - e novamente decodificada de forma fidedigna pela sua representação como uma imagem.

Pôde-se entender que embora existam esquemas para a comunicação, o designer tem a liberdade para propor os que ele considerar relevante para o sistema. Conforme já mencionado no capítulo 2 , os esquemas não se constituem como uma cartilha ou manual que o designers devem seguir rigorosamente. São considerações mais abrangentes das propriedades a serem exploradas nas relações dos elementos do sistema que irão também direcionar a postura e as ações do designer durante o processo de design. 


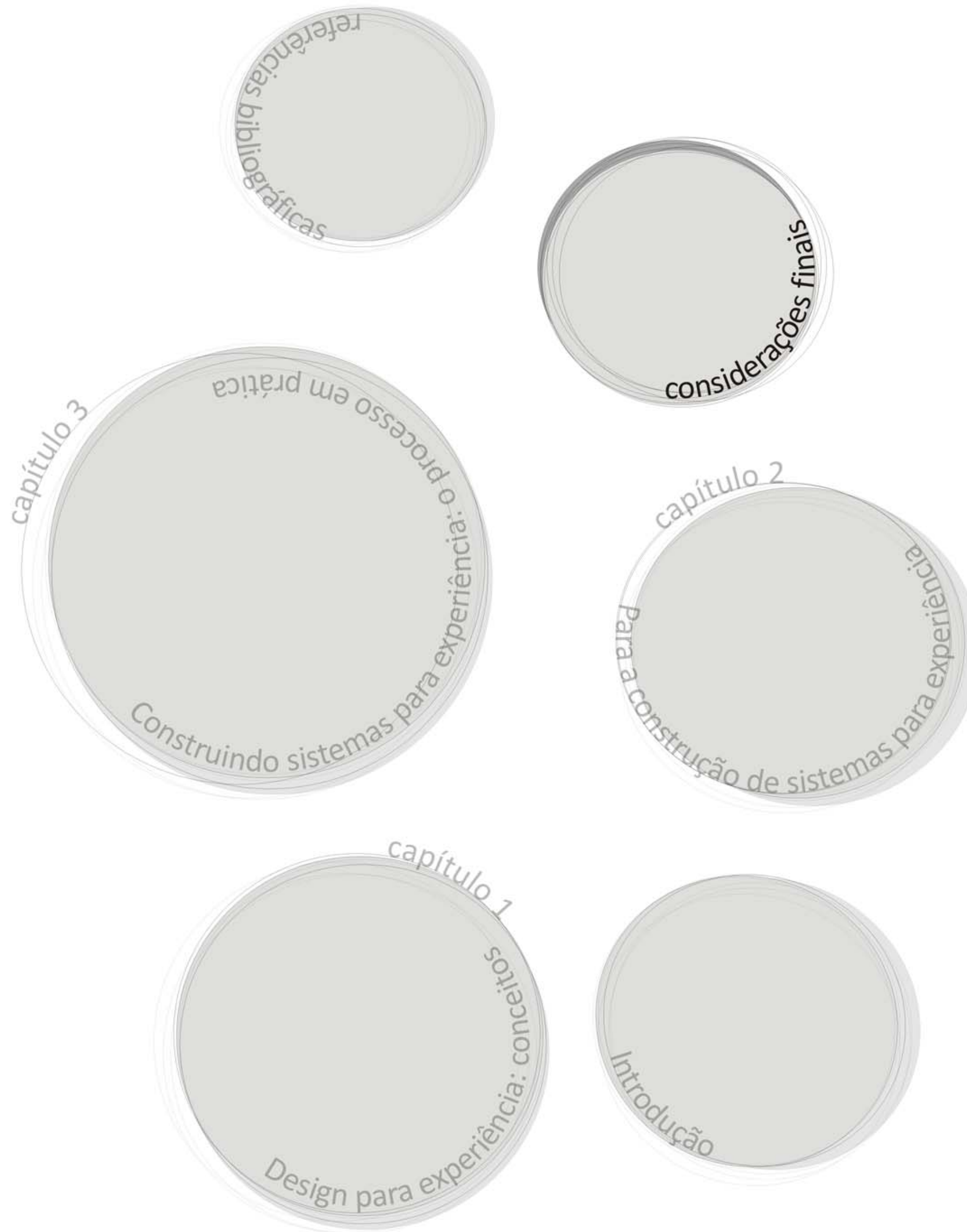



Essa pesquisa de Mestrado procurou discutir e refletir sobre o processo de design de sistemas para experiência. Entretanto, os resultados obtidos nesta pesquisa extrapolam os próprios limites definidos enquanto proposta de investigação acadêmica. Nestas considerações finais, procura-se refletir sobre os resultados obtidos incluindo outras observações relevantes sobre processos de design que não faziam parte do escopo desta pesquisa, mas que auxiliam a construção de uma visão abrangente sobre a postura do designer ao explorar relações entre indivíduos e objetos segundo os princípios do design para experiência.

As reflexões mais relevantes que podem ser feitas sobre esta pesquisa são apresentadas a seguir. Inicia-se com o foco deste trabalho, o processo de design. Segue-se pelas inferências a serem feitas sobre outros resultados que não estavam entre os objetivos da pesquisa, mas que se configuram como elementos importantes para a compreensão do processo.

\section{Processo de design}

Este trabalho procurou entender como podem ser as relações entre indivíduo e objeto interativo dentro dos sistemas que levam a experiências. As relações foram exploradas por questões vinculadas à interação entre pessoas e objetos, à comunicação entre as pessoas, à percepção das pessoas sobre algo e às formas como elas conseguem reter informações sobre esse algo percebido por seus sensores. Esse trabalho considera que essas questões são importantes para a construção de sistemas para experiência, de forma que o designer deve explorá-las durante o processo de design, mas especialmente no início do processo, como ponto de partida. Colocando em relevância tais questões, entende-se que as ações do designer podem assumir um caráter outro, que não prioriza o desenvolvimento dos aspectos formais, funcionais e estéticos ao pensar na 
relação entre indivíduo e objeto interativo. As ações do designer partiriam para uma abordagem dos sistemas para experiência guiada pelas propriedades das relações entre os elementos do sistema e não pelas propriedades de um dos elementos apenas.

O partido para as ações do designer estaria na definição do sistema. Isso significa desenvolver interações possíveis elencando os elementos do sistema, estabelecendo suas condições de encontro e os vínculos fortes entre eles. Para estimular as interações, pode-se explorar as percepções sensórias das pessoas. No entanto, não bastaria apenas criar o estímulo sensorial. Ele precisa conter certo grau de novidade para que possa ser percebido pelas pessoas.

Essas informações recebidas pelas pessoas precisam ser processadas e armazenadas na mente. Para que isso aconteça, é necessário que as pessoas associem significados às coisas percebidas. Além disso, elas precisam envolver-se em sua relação com o objeto interativo ou com outros elementos do sistema. Para isso, essa relação precisa ser desafiadora, configurando-se portanto como uma atividade flow. Ao designer cabe a competência de construir as relações entre indivíduos e objetos de forma que as pessoas se sintam envolvidas com aquilo estão fazendo. Assim, o designer precisa construir nas relações entre os elementos do sistema para a interação de forma que elas promovam situações de envolvimento entre pessoas e objetos interativos. Com isso, se fornece as condições necessárias para a promoção de experiências.

A comunicação também pode promover situações de engajamento. Nesse caso, pessoas comunicam-se entre si e não com o objeto. $O$ objeto é o mediador dessa relação, mas através dele é possível envolver as pessoas em atividades de comunicação em que se verifiquem desafio, envolvimento 
e criatividade. O designer tem o papel de trabalhar as formas de comunicação entre as pessoas de forma a estimular essas situações.

Os projetos ÉOS e z.IP desenvolvidos no Nomads.usp auxiliaram no entendimento desse processo de design de sistemas para experiência. Neles, os designers recorreram a essas abordagens da relação entre indivíduo e objeto, ou seja, procuraram definir os sistemas, os elementos em interação e as propriedades a serem exploradas na relação.

Entretanto, conforme pode se perceber nas leituras dos processos, tanto pelos objetos do banco de dados quanto pelas experimentações do próprio Nomads.usp, as recomendações apresentadas para as ações dos designers não se constituem como regras rígidas e inflexíveis. Permitem aberturas para outras abordagens a partir das quais outras ações para o processo de design podem surgir.

A necessidade de indicar possíveis caminhos para as ações projetuais durante o processo de design por meio das considerações sobre interação, percepção, memória e comunicação, resulta de uma reflexão sobre como trabalhar a relação do indivíduo com o objeto interativo de forma mais consciente e criteriosa, principalmente no que tange o uso das tecnologias de comunicação e informação - que muitas vezes deslumbram designers e arquitetos, que recorrem a sua utilização em objetos e espaços de forma indiscriminada.

Os projetos do Nomads.usp possibilitaram aos pesquisadores pensar de forma diferenciada, permitindo-se explorar outras possibilidades de abordagem de suas proposições, tomando decisões e selecionado propriedades e elementos do sistema de forma mais consciente e intencional, seguindo os princípios norteadores do design para experiência. Entretanto, os projetos da ÉOS, do z.IP e do PIX também permitiram a 
reflexão sobre outros aspectos relacionados ao processo de design que permitem uma compreensão ampliada sobre ele.

\section{As tecnologias de informação e comunicação}

As considerações feitas em relação ao uso das tecnologias de informação e comunicação no processo de design enfatizaram sua apropriação enquanto recurso condicional para potencializar os sistemas para experiência. A importância das TIC para os sistemas para experiência reside principalmente em sua capacidade de agregar novos esquemas para a comunicação entre pessoas, em instâncias temporais e espaciais. Permitem ainda alterações desses esquemas mesmo com o sistema definido pelo designer. As questões sobre o uso das TIC são condição para os sistemas, ou seja, elas fazem parte do sistema para experiência. Compreender e saber explorar os fenômenos tecnológicos em suas proposições faz parte das competências que o designer deve possuir.

Entretanto, as tecnologias de informação e comunicação assumem no processo de design outra forma além de condição para os sistemas para experiência. Elas se configuram como condições de trabalho do próprio designer. Apresentam-se como um meio de comunicação poderoso capaz de articular as ações entre designers que podem se encontrar tanto presencialmente como também remotamente por meio comunicadores ou outros tipos de ferramentas de comunicação e colaboração à distância. Em centros de pesquisa, projetos financiados por diversas instituições de fomento à pesquisa têm se dedicado ao desenvolvimento de plataformas colaborativas, como a do programa TIDIA-AE - Tecnologia da Informação no Desenvolvimentos da Internet Avançada - Aprendizado Eletrônico, financiada pela FAPESP. O projeto do Nomads.usp nesse programa volta-se para o processo de design remoto colaborativo para o desenvolvimento de objetos interativos. Dentro desse contexto destaca-se também o projeto 
Uni-verse $^{92}$ resultado de um consórcio entre várias instituições, incluindo o Interactive Studio ${ }^{93}$ e o produtor do software Blender $^{94}$ para modelagem em 3D. O objetivo desse projeto é construir uma plataforma de colaboração para arquitetos e designers desenvolverem projetos à distância, entre outras possibilidades de uso, utilizando a internet como canal de comunicação.

Enquanto ferramenta de trabalho representada pelo computador, as TIC possibilitam ainda várias atividades as quais o designer pode recorrer como, por exemplo, o empreendimento de outras formas de representação de suas proposições, desenvolvimento de peças prototípicas por fresadoras e impressoras 3D a partir de modelagens feitas no computador, elaboração da programação dos micro-controladores dos objetos interativos, além da produção das interfaces gráficas que fazem parte dos esquemas de comunicação entre pessoas.

Cada vez mais designers arquitetos apóiam-se nas TIC para o desenvolvimento de suas propostas e a questão que se coloca é o quanto o uso das TIC influencia no processo de design e nos próprios resultados desse processo. A questão tem instigado muitos pesquisadores, inclusive os do Nomads.usp ${ }^{95}$.

\footnotetext{
92 O projeto Uni-verse reúniu centros de pesquisas de vários países da União Européia e foi financiado pelo EU Sixth Framework Programme. O software possui código aberto e sua última atualização, feita em 2007, está disponível para download na página da internet do projeto: <http://uni-verse.org/Uni-verse-Home.72.0.html>.

${ }_{93}$ O Interactive Institute, localizado na Suécia, trabalha com na interlocução entre arte, tecnologia da informação e design. Um de seus grupos de pesquisa, o extinto Smart Studio, teve peças analisadas nesta Dissertação de Mestrado.

${ }^{94} \mathrm{O}$ Blender é um software para modelagem e animações em 3D. Desenvolvido pela Blender Foundation, o software possui código aberto e está disponível para download na página da organização: <http://www.blender.org>

95 Entre uma das pesquisas do Nomads.usp que aborda as Tecnologias de Informação e Comunicação no processo de design destaca-se a Dissertação de Mestrado de Requena (2007), intitulada "Habitar híbrido: interatividade e experiência na era da cibercultura".
} 


\section{Design_lab: o espaço do designer}

O Design_lab, projeto também desenvolvido no Nomads.usp, procura explorar como as tecnologias digitais influenciam no processo de design. Resulta de uma reflexão imposta pelos projetos da Pacto Digital, ÉOS, z.IP e PIX. Trata-se de um laboratório que tem como objetivo estimular e instigar o designer além de contemplar o trabalho colaborativo tanto presencialmente como remotamente, sincronamente e assincronamente. Os conceitos envolvendo o design para experiência também foram fatores contribuintes para a elaboração desse espaço.

Esse laboratório daria o suporte para todas as etapas do processo de design desde as primeiras considerações a serem realizadas pelos designers como também na etapa de produção da programação dos micro-controladores, produção dos componentes eletrônicos e até mesmo a prototipagem física de parte do objeto interativo. Procura, portanto dar as condições necessárias para o desenvolvimento do objeto interativo contemplando todas as atividades relacionadas a ele.

Entretanto, a proposta para a construção de um espaço não se coloca como pressuposto e nem como uma condição para o desenvolvimento de objetos interativos. Sua existência é resultado de reflexões dos pesquisadores em relação as suas atividades enquanto designers. Talvez cada equipe deva procurar por espacialidades mais adequadas para seu trabalho.

No desenvolvimento de objetos interativos, sejam eles pautados no design para experiência ou não, entende-se que o processo não é linear e sequencial. O designer pode desenvolver a programação ao mesmo tempo em que faz os protótipos físicos, pode pensar em interações possíveis com outros objetos ou com as pessoas, pode ainda alterar o que já foi feito e inserir componentes eletrônicos novos. Assim, esse seria o espaço que 
contemplaria essas atividades que podem acontecer até de forma simultânea.

\section{Abrangência do conhecimento e equipe multidisciplinar}

Pelos objetos procurou-se entender quais eram as intenções dos designers. Entretanto uma informação relevante para o processo de design não se encontrava no objeto em si. Trata-se das informações sobre os desenvolvedores dos objetos. A maioria dos selecionados para a leitura apresentava como autores uma equipe de profissionais de formações diversas. Nas considerações feitas sobre o interaction design no capítulo 1 desta Dissertação de Mestrado, autores assinalam para a necessidade de se construir uma equipe multidisciplinar que trabalhe para o desenvolvimento de produtos por essa abordagem do design (MOGGRIDGE, 2007; SHARP; PREECE; ROGERS, 2007; WINOGRAD, 1997). O processo de design, portanto, envolve a colaboração de profissionais de áreas diversas convergindo para o mesmo objetivo.

Da mesma forma, o processo de design dos sistemas para experiência também deve ser conduzido por uma equipe multidisciplinar. Porém, quando se fala em equipe multidisciplinar, enfatiza-se que o termo equipe deve ser entendido como um grupo de pessoas trabalhando juntas para realização de algo, cujas decisões não cabem a um ou outro membro da equipe, mas sim refletem a decisão do grupo. Não se trata de consultoria, prática na qual uma pessoa, ciente de suas capacidades e habilidades enquanto profissional, presta assessoria sobre determinado assunto. Também não se trata da contratação de profissionais para realizar uma parte específica do projeto. A consolidação dessa equipe é de fundamental importância, se possível, desde as primeiras ações a serem tomadas frente àquilo que se quer desenvolver. 
O envolvimento dos membros da equipe para a realização do projeto também é essencial para o processo de design. Essa constatação veio dos projetos Pacto Digital, ÉOS, z.IP e PIX. Na Pacto Digital, o processo iniciou-se apenas com arquitetos trabalhando no projeto. Em um determinado momento do projeto, profissionais da área de automação e da tecnologia da informação foram requisitados. Porém, por não estarem envolvidos com o projeto, a comunicação e as ações dos membros da equipe foram comprometidas e isso se refletiu nas decisões tomadas frente ao projeto. No PIX a equipe sofreu várias modificações, com a entrada e saída de membros e de formações diferente, mas o envolvimento deles com o projeto não comprometeu de forma negativa para o resultado final, ao contrário, apenas contribuiu positivamente para o projeto. Isso pode ter ocorrido devido à própria proposta do PIX. Desde o início do projeto ele já se posicionava como uma plataforma de investigação dos próprios pesquisadores do Nomads.usp e os resultados a serem alcançados estavam bem claros. A equipe ocupou-se mais com o fazer técnico e talvez essa condição tenha facilitado a dinâmica da equipe sem implicações que comprometessem o resultado final.

Para a ÉOS e o z.IP foram montadas equipes multidisciplinares cujos membros participaram do processo desde as primeiras considerações sobre como pensar e trabalhar a relação do indivíduo com o objeto pelas teorias dos sistemas, pelos processos perceptivos, pela comunicação entre outras possibilidades de abordagem. A equipe de design contou ativamente com a participação de todos os membros, sendo eles arquitetos, cientistas da computação ou engenheiros. E mais uma vez se aponta para a questão do envolvimento de cada membro com o projeto a ser desenvolvido como uma condição fundamental para garantir a integridade do processo de design. 
Outro ponto importante a ser ressaltado e que emergiu das avaliações feitas do próprio processo de design, nos projetos desenvolvidos no Núcleo, refere-se à necessidade de uma abrangência de conhecimento dos membros da equipe. Cada membro é dotado de competências que contribuem para o desenvolvimento de objetos interativos. Mas cada um deve também adotar uma postura favorável ao trabalho em equipes multidisciplinares, estando aberto ao aprendizado de conhecimentos que extrapolem sua área original de formação, ampliando-a.

\section{Perspectivas futuras}

Para futuras pesquisas, aponta-se para a necessidade de se compreender mais sobre processos de design. Essa pesquisa trabalhou alguns pontos do processo quando baseados nos conceitos do design para experiência, mas há ainda muitos pontos a serem elucidados. Mas enfatiza-se a importância de se explorar, nessas novas investigações, a aproximação entre teoria e prática, como um caminho para se ampliar o entendimento sobre o objeto de estudo - especialmente para as pesquisas pautadas por essa temática.

Desse processo, sugere-se a realização de estudos sobre espaços para o desenvolvimento de atividades do design de objetos interativos, sejam eles pautados pelos princípios do design para experiência ou não, visando compreender o quanto a espacialidade, física e virtual, influência no resultado final desse processo. Nesse contexto, seria importante entender como o designer desenvolve objetos com TIC usando como meios de trabalho as próprias TIC e como os espaços físicos estão relacionados com a produção de conhecimento. Isso também envolveria o estudo sobre plataformas colaborativas, formas de representação e de produção dos objetos com TIC. 
Também pode ser adotado como mais uma possibilidade de investigação acadêmica o entendimento do processo de design como um todo por uma visão sistêmica. Envolveria desde à forma como é feita a abordagem o objeto a ser desenvolvido até as relações entre os próprios membros da equipe. Significaria considerar as relações entre membros da equipe, o objeto a ser desenvolvido por ela e todas as ações nesse processo como partes de um sistema no qual interações, qualidades e propriedades de cada elementos poderiam ser estudadas.

Por fim, espera-se que essa pesquisa de Mestrado possa contribuir para a constituição do design para experiência enquanto disciplina, trazendo para o campo do debate acadêmico a discussão dos processos de design envolvidos nessa abordagem do design. Acredita-se que a construção deste trabalho, baseado no estabelecimento de diálogos entre saberes de diversos campos disciplinares, seja capaz de incentivar pesquisadores a lançarem olhares mais abrangentes sobre este tema, contribuindo para a formação de um conhecimento diversificado, porém conciso em sua essência, sobre o design para experiência. 


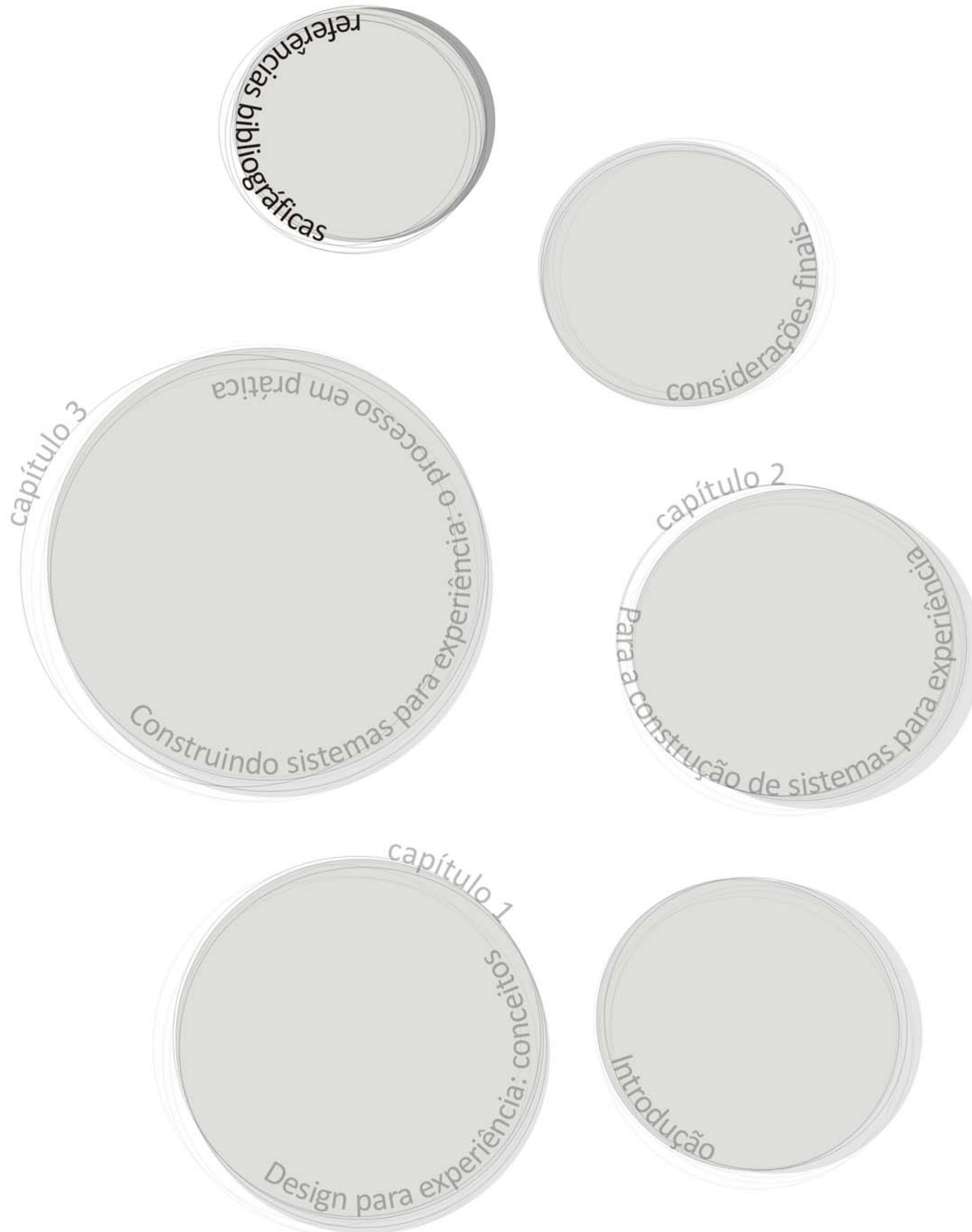



ABBAGNANO, N. (1970). História da filosofia. Lisboa: Presença. v.13.

ACKERMAN, D. (1995). A Natural history of the senses. New York: Vintage Books.

ALQUIÉ, F. (1974). Berkeley. In: CHATELET, F. (Org.). História da filosofia: idéias e doutrinas. Rio de Janeiro: Zahar. v.4, p.42-58.

AMARAL, M.N.C.P. (1990). Dewey: filosofia e experiência democrática. São Paulo: Perspectiva.

ANDERSON, J.R. (2000). Cognitive psychology and its implications. 5.ed. New York: Worth.

ARDILL, R. (2008). Experience design: an overview of experience design. Disponível em:<http://www.designcouncil.org.uk/en/About-Design/DesignDisciplines/Experience-design/>. Acesso em: 11 Oct. 2008.

BERLO, D.K. (1972). O Processo da comunicação: introdução à teoria e prática. Rio de Janeiro: Fundo de Cultura.

BERTALANFFY, L.V. (1977). Teoria geral dos sistemas. Tradução de Francisco M.Guimarães. Petrópolis: Vozes.

BLAUBERG, I.V.; SADOVSKY, V.N.; YUDIN, E.G. (1977). Systems theory: philosophical and methodological problems. Moscow: Progress.

BREHIER, E. (1977a). História da filosofia: a filosofia moderna - o século XVII. São Paulo: Mestre Jou. 
(1977b). História da filosofia: a filosofia moderna - o século XVIII.

São Paulo: Mestre Jou.

CASTELLS, M. (2005). A Sociedade em rede. Tradução de Roneide Venancio Majer. São Paulo: Paz e Terra.

CHATELET, F. (1974). Prefácio. In: (Org.). História da filosofia: idéias e doutrinas. Rio de Janeiro: Zahar. v.4.

CHERRY, C. (1971). A Comunicação humana. São Paulo: Cultrix.

CSIKSZENTMIHALY, M. (1981). The Meaning of things: domestic symbols and the self. Cambridge: Cambridge University Press.

. (1991). Flow: the psychology of optimal experience. New York: Harper Perenial.

CYTOWIC, R.E. (1989). Synesthesia: a union of senses. Nova York: SpringerVerlag.

DELEUZE, G. (1974). Hume. In: CHATELET, F. (Org.). História da filosofia: idéias e doutrinas. Rio de Janeiro: Zahar. v.4, p.59-70.

DESIGN INTERACTION AT THE RCA. (2009). Vector memory. Disponível em:<http://www.interaction.rca.ac.uk/people/alumni/07-09/dotsamsen/projects/project2.html>. Acesso em: 25 Jan. 2009.

DEWEY, J. (1980). Experiência e natureza; lógica a teoria da investigação; a arte como experiência; vida e educação; teoria da vida moral. Tradução 
de Murilo Otávio Rodrigues Paes Leme; Anísio S.Teixeira e Leonidas Contijo de Carvalho. São Paulo: Abril Cultural. (Os Pensadores).

DIX, A. et al. (2004). Human-computer interaction. Harlow: Pearson Prentice Hall.

DOURISH, P. (2001). Where the action is: the foundations of embodied interaction. Cambrigde: MIT.

DUCHESNEAU, F. (1974). John Locke. In: CHATELET, F. (Org.). História da filosofia: idéias e doutrinas. Rio de Janeiro: Zahar. v.4, p.17-41.

DUNNE, A. (2005). Hertzian Tales: electronic products, aesthetic experience and critical design. Cambridge: MIT.

EGMOND, R. (2008). The Experience of product sounds. In: SCHIFFERSTEIN, H.N.J.; HEKKERT, P. (Ed.). Product experience. San Diego: Elsevier.

FRAMPTON, K. (1997). História crítica da arquitetura moderna. São Paulo: Martins Fontes.

FRAZER, J.H. (2001). The Cybernetics of architecture: a tribute to the contribution of Gordon Pask. Kybernetes, Wagon Lane, v.30, n.5/6, p.641651.

GREFÉ, R. (2000). (Form + content + context $) \div$ time $=$ experience design. Gain: AIGA Journal of Design for Network Economy, New York, v.1, n.1, p.14.

HAQUE, U. (2006a). Arquitetura, interação e sistemas. Arquitetura \& Urbanismo, São Paulo, n.149, p.68-71, ago. 
. (2006b). Evolving sonic environment III. Disponível em:<http://www.haque.co.uk/evolvingsonicenvironment.php>. Acesso em: 25 Jan. 2009.

HEHE. (2005). Pollstream. Disponível em:<http://hehe.org.free.fr/hehe/pollstream/index.html>. Acesso em: 13 Oct. 2008

HEKKERT, P.; SCHIFFERSTEIN, H.N.J. (2008). Introducing product experience. In: SCHIFFERSTEIN, H.N.J.; HEKKERT, P. (Ed.). Product experience. San Diego: Elsevier.

HELLER, S.; GLUNK, N. (1989). Seventy- five years of AIGA. New York: AIGA. Disponível em:<http://www.aiga.org/content.cfm/about-history75thanniversary>. Acesso em: 26 Dec. 2008.

HESKETT, J. (1997). Desenho industrial. Rio de Janeiro: José Olympio.

$\begin{array}{llll}\text { INTERACT LAB. (2004). Dynamo. } & \text { Disponível }\end{array}$ em:<http://www.informatics.sussex.ac.uk/research/groups/interact/previo usSite/projects/dynamo.htm>. Acesso em: 15 Mar. 2008.

INTERACTION DESIGN INSTITUTE IVREA. (2001). Mission. Disponível em:<http://interactionivrea.org/en/about/theinstitute/mission/index.asp>. Acesso em: 22 Dec. 2008.

INTERACTION DESIGN INSTITUTE IVREA. (2004). Tableportation. Disponível em:<http://www.interaction-ivrea.it/theses/200304/tableportation/>. Acesso em: 22 May 2007. 
_. (2005a). Strangely familiar future. Disponível em:<http://projectsfinal.interactionivrea.org/web/description/ex_strange_ 05.html>. Acesso em: 29 Jan. 2009.

(2005b). Tè-per-te: an interactive therapeutic tea system. Disponível em:<http://interactionivrea.org/en/gallery/teperte/index.asp>. Acesso em: 25 Jan. 2009.

JAGT, P.V.D. (1994). Bottoms up doorbell. Disponível em:<http://www.droog.com/products/accessories/bottoms-up-doorbell/>. Acesso: 22 Jan. 2008.

JAMES, W. (1979). Pragmatismo e outros textos. Tradução de Jorge Caetano da Silva e Pablo Rubén Mariconda. São Paulo: Abril Cultural. (Os Pensadores).

JONES, C.A. (2006). The Mediated sensorium. In: (Ed.).

Sensorium: embodied experience, technology, and contemporary art. Cambridge: MIT. p.5-49.

LANDAU, R. (1984). A Philosophy of enabling. In: PRICE, C. The Square book. Chichester: Wiley-Academy.

LOCKE, J. (1952). An Essay concerning human understanding. In: HUTCHINS, R.M. (Ed.). Great books of the western world: Locke, Berkeley, Hume. Chicago: Willian Benton. v.35, p.85-395.

MALDONADO, T. (1991). Design industrial. Lisboa: Edições 70. 
MANZINI, E. (2007). A Laboratory of ideas: diffuse creativity and new ways of doing. In: MERONI, A. (Ed.). Creative communities: people inventing sustainable ways of living. Milano: POLI.design.

MANZINI, E.; VEZZOLI, C. (2005). O Desenvolvimento de produtos sustentáveis: os requisitos ambientais dos produtos industriais. Tradução de Astrid de Carvalho. São Paulo: EDUSP.

McCARTHY, J.; WRIGHT, P. (2004). Technology as experience. Cambridge: MIT.

McCUlLOUGH, M. (2005). Digital ground: architecture, pervasive computing, and environmental knowing. Cambridge: MIT.

MERONI, A. (2005). Apunti sul concetto de design per l'esperienza. Milano: Facoltà del Design. Material didático.

MILLER, G.A. (1956). The Magical number seven, plus or minus two: some limits on our capacity for processing information. The Psychological Review, Princeton, v.63, n.2, p.81-97, Mar.

MOGGRIDGE, B. (2007). Designing interactions. Cambridge: MIT.

MORIN, E. (2005). O Método 1: a natureza da natureza. Tradução de llana Heineberg. Porto Alegre: Sulina.

MOTA, O.S.; HEGENBERG, L. (1975). Introdução e notas dos autores. In: PEIRCE, C.S. Semiótica e filosofia. São Paulo: Cultrix.

MUGGE, R.; SCHOORMANS, J.P.L.; SCHIFFERSTEIN, H.N.J. (2008). Product attachment: design strategies to stimulate the emotional bonding to 
products. In: SCHIFFERSTEIN, H.N.J.; HEKKERT, P. (Ed.). Product experience. San Diego: Elsevier.

NARDELLI, N. (2007). Design para experiência e as tecnologias de informação e comunicação. 239p. Dissertação (Mestrado) - Escola de Engenharia de São Carlos, Universidade de São Paulo, São Carlos, 2007.

NEGROPONTE, N. (1995). A Vida digital. Tradução de Sérgio Tellaroli. São Paulo: Companhia das Letras.

NOMADS.USP: núcleo de estudos de habitares interativos. (2008a). Arquivo fotográfico. São Carlos: USP/EESC/Departamento de Arquitetura e Urbanismo.

(2008b). Memorial explicativo do anteprojeto. São Carlos: USP/EESC/Departamento de Arquitetura e Urbanismo.

(2008c). Pacto digital. São Carlos: USP/EESC/Departamento de Arquitetura e Urbanismo. [Apresentação de slides].

NOMADS.USP: núcleo de estudos de habitares interativos. (2008d). PIX. São Carlos: USP/EESC/Departamento de Arquitetura e Urbanismo. Disponível em:<http://www.nomads.usp.br:8080/PIX/>. Acesso em: 5 nov. 2008

(2008e). z.IP. São Carlos: USP/EESC/Departamento de Arquitetura e Urbanismo. [Apresentação de slides].

— (2009a). Arquivo fotográfico. São Carlos: USP/EESC/Departamento de Arquitetura e Urbanismo. 
. (2009b). Éos. Nomads. São Carlos: USP/EESC/Departamento de Arquitetura e Urbanismo. [Apresentação de slides].

NORMAN, D. (2002). The Design of everyday things. New York: Basic Books.

PASK, G. (1969). The Architectural relevance of cybernetics. Architectural Design, London, v.39, p.494-496, Sept.

PEIRCE, C.S. (1999). Semiótica. São Paulo: Perspectiva. . (1975). Semiótica e filosofia. Introdução, seleção e tradução de Octanny Silveira da Mota e Leonidas Hegenberg. São Paulo: Cultrix; EDUSP.

PINE, B.J.; GILMORE, J.H. (1999). The Experience economy: work is a theatre \& every business a stage. Boston: Harvard Business School Press.

PRICE, C. (2003). The Square book. Great Britain: Wiley-Academy.

PRIMO, A. (2000). Interação mútua e reativa: uma proposta de estudo. Revista da Famecos, Porto Alegre, n.12, p.81-92, jun. Disponível em:<http://www.ufrgs.br/limc/PDFs/int_mutua_reativa.pdf $>$. Acesso em: 8 dez. 2008.

R\&SIE(N) ARCHITECTS. (2007). MI(pi) bar/ MIT. Disponível em:<http://www.new-territories.com/mitpibar.htm>. Acesso em: 11 Jan. 2009.

REICHARDT, J. (1969). Introduction. In: (Ed.). Cybernetic serendipity: the computer and the arts. New York: Frederick A.Praeger. 
RIFKIN, J. (2000). The Age of access: the new culture of hypercapitalism where all of life is a paid-for experience. New York: Penguin Putnam.

SANDERS, E.B.N. (2002). Scaffolds for experiencig in the new design space. In: INFORMATION design. Tokyo: Institute ofr Information Design Japan; Graphic-Sha.

SCHIFFERSTEIN, H.N.J.; SPENCE, C. (2008). Multsensory product experience. In: SCHIFFERSTEIN, H.N.J.; HEKKERT, P. (Ed.). Product experience. San Diego: Elsevier.

SHANNON, C.E. (1948). A Mathematical theory of communication. The Bell System Technical Journal, New York, v.27, p.379-423, 623-656, July/Oct.

SHARP, H.; ROGERS, Y.; PREECE, J. (2007). Interaction design: beyond human computer interaction. Londres: John Wiley.

SHEDROFF, N. (2001). Experience design 1. Indianápolis: New Riders.

SMART STUDIO. (2000). BrainBall. Disponível em:<http://smart.tii.se/smart/projects/brainball/index_en.html>. Acesso em: 20 Jan. 2009.

(2001). Brainbar. Disponível em:<http://smart.tii.se/smart/projects/brainbar/index_en.html>. Acesso em: 20 Jan. 2009.

(2003). Remote home. Disponível em:<http://smart.tii.se/smart/projects/remotehome/index_en.html>. Acesso em: 20 Jan. 2009. 
SONNEVELD, M.H.; SCHIFFERSTEIN, H.N.J. (2008). The Tactual experience of objects. In: SCHIFFERSTEIN, H.N.J.; HEKKERT, P. (Ed.). Product experience. San Diego: Elsevier.

THACKARA, J. (2001). The Design challenge of pervasive computing. Interactions, New York, v.8 , n.3, p.46-52, May/June.

TRAMONTANO, M. (1998). Novos modos de vida, novos espaços de morar, Paris, São Paulo, Tokyo: uma reflexão sobre habitação contemporânea. 399p. Tese (Doutorado) - Faculdade de Arquitetura e Urbanismo, Universidade de São Paulo, São Paulo, 1998.

VERNON, M.D. (1974). Percepção e experiência. São Paulo: Perspectiva.

VISSER, A. (2001). Functions tiles and tile kitchen. Disponível em:<http://www.arnoutvisser.com/function\%20tiles\%20and\%20tile\%20kitc hen.html>. Acesso em: 26 Jan. 2009.

VITA, L.W. (1968). Pequena história da filosofia. São Paulo: Saraiva.

WIENER, N. (1968). Cibernética e sociedade: o uso humano dos seres humanos. Tradução de José Paulo Paes. São Paulo: Cultrix.

WINOGRAD, T. (1997). From computing machinery to interaction design. In: DENNING, P.; METCALFE, R. (Ed.). Beyond calculation: the next fifty years of computing. Nova York: Springer-Verlag. p.149-162. 